\title{
Transition Metal-Free Amine Oxidation: a Chemoselective Strategy for the Late-Stage Formation of Lactams
}

\author{
Robert J. Griffiths, ${ }^{\dagger, \ddagger}$ Glenn A. Burley, ${ }^{\ddagger} * *$ Eric P.A. Talbot ${ }^{\dagger, *}$ \\ † GlaxoSmithKline Medicines Research, Gunnels Wood Road, Stevenage, Hertfordshire, SG1 2NY, UK \\ * Department of Pure and Applied Chemistry, University of Strathclyde, 295 Cathedral Street, Glasgow, G1 1XL \\ Supporting Information Placeholder
}

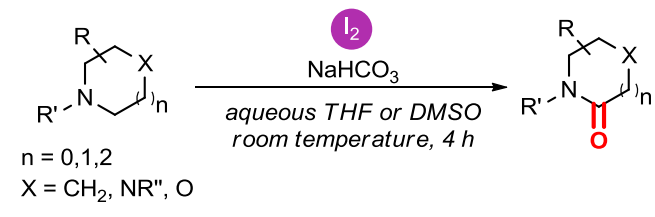

$\mathrm{n}=0,1,2$

$\mathrm{X}=\mathrm{CH}_{2}, \mathrm{NR} ", \mathrm{O}$

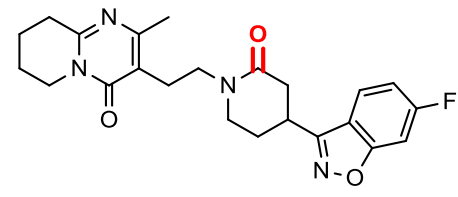

Oxo-rispoeridone, $57 \%$ isolated yield
- 26 examples of amine $\mathrm{C}-\mathrm{H}$ oxidation
-10 examples of chemoselective late-
stage lactamization
- Retention of stereochemistry
- Up to $96 \%$ yield

\begin{abstract}
This manuscript describes a metal-free strategy for the formation of lactams via selective oxidation of cyclic secondary and tertiary amines. Molecular iodine facilitates both chemoselective and regioselective oxidation of C-H bonds directly adjacent to a cyclic amine. The mild conditions, functional group tolerance and substrate scope are demonstrated using a suite of diverse small molecule cyclic amines, including clinically approved drug scaffolds.
\end{abstract}

Late-stage C-H oxidation is a step- and atom-efficient strategy to tune the efficacy and physicochemical properties of biologically-active small molecule scaffolds. ${ }^{1}$ The underlying driver of this powerful approach is the facile and chemoselective oxidation of $\mathrm{C}-\mathrm{H}$ bonds in complex molecular architectures by exploiting the subtle differences in $\mathrm{C}-\mathrm{H}$ bond reactivity. This in turn enables the formation or diversification of molecular frameworks that would otherwise require the development of a dedicated synthetic route at an early stage in the process. Of the myriad of privileged heterocycles found in clinically-approved medicinal agents and natural products, ${ }^{2}$ the lactam motif is ubiquitous. ${ }^{3}$ From a medicinal chemistry perspective, lactams reduce the hydrophilicity of secondary and tertiary ammonium species, and provide additional hydrogen bond acceptor sites that could enhance drug efficacy and potentially reduce toxicity. Current preparative methods of lactams typically involve condensation of amines with a tethered carboxylic acid, ${ }^{4}$ Beckmann rearrangement, ${ }^{5}$ or dehydrogenative coupling of amines with alcohols. ${ }^{6}$ Each of these strategies involve lactam formation early in the synthetic sequence, which in turn limits the downstream diversification of complex molecular scaffolds.

A comparative process that involves the formation of the lactam moiety by chemoselective oxidation of cyclic amines is less well refined, and typically requires the use of expensive and toxic transition metal catalysts such as osmium ${ }^{7 \mathrm{a}}$ or mercury ${ }^{7 \mathrm{~b}}$ complexes and harsh oxidative conditions such as organic peroxides $^{7 \mathrm{c}-\mathrm{e}}$ or ruthenium oxides. ${ }^{7 \mathrm{f}-\mathrm{h}}$ Recent work by Milstein et al. shows that catalytic oxidation of cyclic amines to the corresponding lactam is indeed possible, although the efficiency of this process is limited by the need to heat an air-sensitive ruthenium catalyst 1 , to $150{ }^{\circ} \mathrm{C}$ for more than two days to effect this transformation (Figure 1a). ${ }^{8}$

a) Previous work: Ru-catalysed lactam formation (Milstein, 2014) ${ }^{8}$

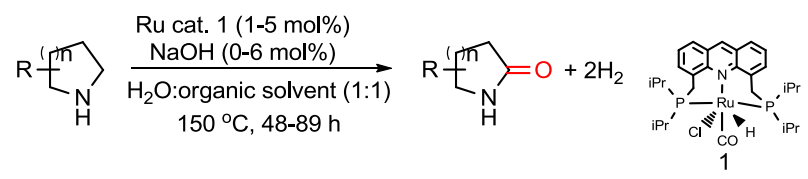

b) Previous work: Fe-catalysed amidation (Emmert, 2015) ${ }^{9}$

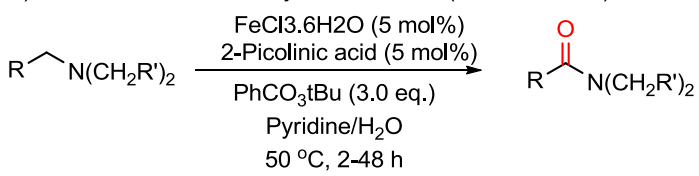

C) This work: Transition metal-free amine oxidation

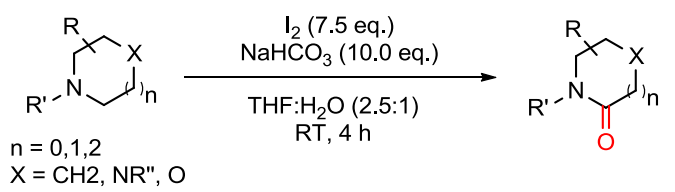

16 examples of amine oxidation on model substrates 10 examples of late-stage oxidation

Figure 1. Lactam formation via $\mathrm{C}-\mathrm{H}$ oxidation of cyclic amines. a) Ruthenium-catalyzed lactam formation; ${ }^{8}$ b) Iron(III)-catalyzed oxidation of acyclic amines; ${ }^{9} \mathrm{c}$ ) Late-stage lactam formation mediated by iodine oxidation of cyclic amines.

Ferric chloride offers a cheap alternative to ruthenium catalysts (Figure 1b), however substrate scope is currently limited 
by the requirement of a strong peroxide oxidant..$^{9}$ Gold nanoparticles supported on alumina do offer a mild and chemoselective route to amide and lactam formation. However, large amounts of this expensive catalyst are required, which is further complicated by the multi-step process to prepare the colloid. ${ }^{10}$ In contrast to the use of transition-metal catalysts, molecular iodine is a mild, cheap and metal-free oxidant ${ }^{11}$ that has been used to chemoselectively oxidize a piperidine ring found in natural products to the corresponding lactam in the presence of aldehyde, alkene, alcohol, and heteroaromatic functionalities. ${ }^{12}$ Although there are a number of reports that describe the use of electrophilic halogen sources to carry out $\alpha$-oxidation of cyclic amines, ${ }^{13}$ these procedures to date have limited functional group tolerance, ${ }^{13 \mathrm{a}}$ and require harsh reaction conditions. ${ }^{13 \mathrm{~b}-\mathrm{e}}$ Herein, we report a general strategy for the chemoselective oxidation of a range of secondary and tertiary saturated N-heterocycles to form $\gamma$-, $\delta$ - and $\varepsilon$-lactams. To explore the selectivity of our approach, a reaction screen was undertaken using the model substrate 2a. The parameters of solvent, concentration, stoichiometry of iodine and iodine source were surveyed (SI, Table S1). Aqueous THF and aqueous DMSO were both found to be optimal solvents, resulting in $91 \%$ and $90 \%$ conversion of $\mathbf{2 a}$ into 3a, respectively. The stoichiometry of iodine and concentration of the substrate proved critical for high conversion to $\mathbf{3 a}$, with 7.5 equivalents of iodine and substrate concentration at 0.025 $\mathrm{M}$ required to produce $96 \%$ of $\mathbf{3 a}$.

With optimized conditions in hand, the substrate scope of this reaction was explored using a range of cyclic amines 2a-r (Scheme 1). Our optimized conditions tolerated both electronrich and electron-poor benzyl-protected piperidines (2b-c) and tetrahydroisoquinoline $\mathbf{2 d}$, with no oxidation of the exocyclic benzylic methylenes observed in 3a-d. Chemoselective oxidation of the cyclic $\alpha-\mathrm{C}-\mathrm{H}$ bond was observed in both five-membered and seven-membered cyclic amines $\mathbf{2 e - f}$, morpholine $\mathbf{2 g}$, and piperazines $\mathbf{2 h}$-i. Interestingly, stalling of the reaction was seen for substrate $\mathbf{2 g}$, which was alleviated by using a DMSO/ $\mathrm{H}_{2} \mathrm{O}$ solvent system instead. In contrast to benzylic substrates 3a-i, concomitant lactamization and para-iodination resulted in the formation of $\mathbf{3} \mathbf{j}$ from $\mathbf{2} \mathbf{j}$. Blocking the para-position of the phenyl ring with a methyl group produced lactam $3 \mathbf{k}$ exclusively. Formation of the secondary lactam 31 and stericallyhindered $\mathbf{3 m}$ was also tolerated. Oxidation of the asymmetric piperidine $\mathbf{2 n}$ formed $\mathbf{3 n} \boldsymbol{\alpha}$ and $\mathbf{3 n} \boldsymbol{\beta}$, isolated in a ratio of 2.7:1, demonstrating bias towards the sterically less-hindered product. Notably, no racemization of the stereogenic centers in $\mathbf{3 m}$ and 3n was observed. Retention of stereochemistry at positions $\beta$-to the nitrogen in morpholine 20 was also observed, with the transorientation of the methyl groups conserved. The stereogenic centre in the proline-derived substrate $\mathbf{2 p}$ was also conserved, which could potentially enable access to non-natural proline derivatives and proline-tagging experiments. However, no reaction was observed with benzoyl-protected $\mathbf{2 q}$ or acyclic substrate $2 \mathbf{r}$. This suggests the availability of the amine lone pair and the conformationally-restricted ring structure is essential for chemoselective oxidation.

With the substrate scope and robustness of this methodology established, the chemoselectivity profile was further explored on a suite of drug molecules (Figure 2). Lactams 5a-e were isolated in moderate to excellent yields (15-92\%), demonstrating chemoselective oxidation in the presence of alkenes, electronrich aromatic rings, pyridines, carboxylic acids and
Scheme 1. Substrate scope of iodine-mediated oxidation of cyclic amines.

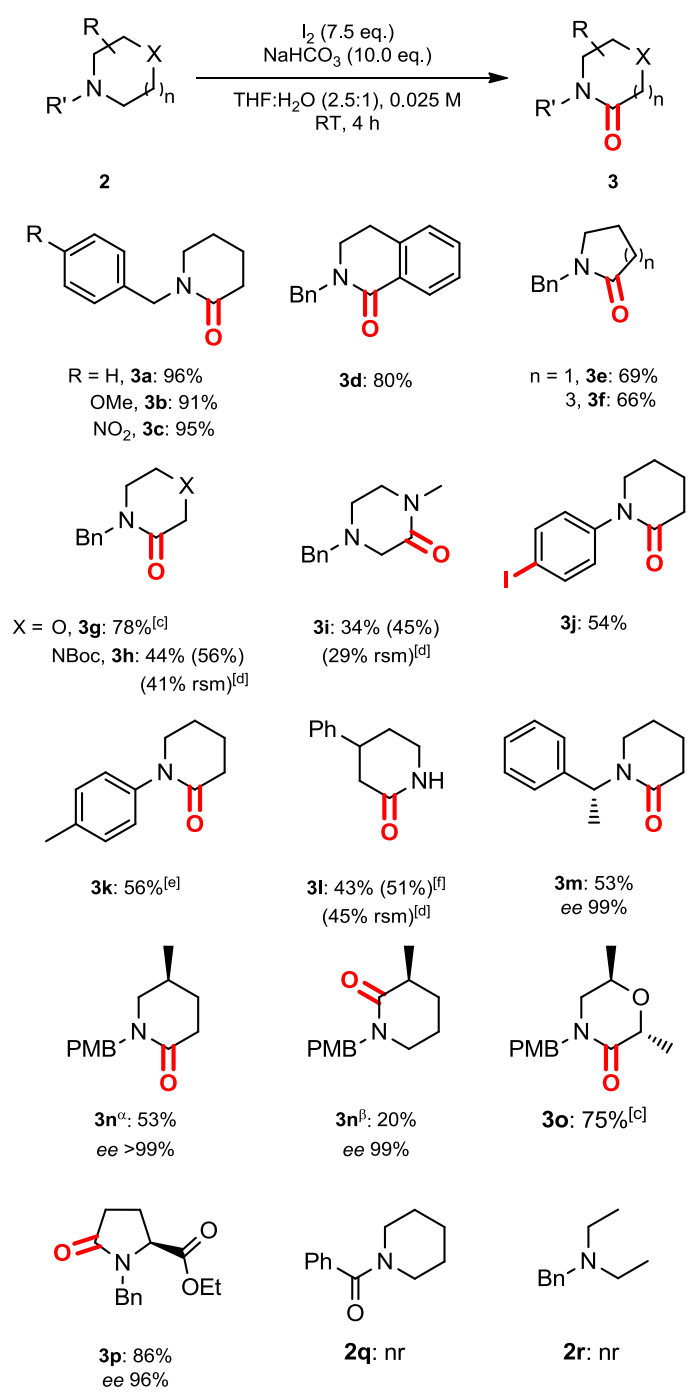

a) Conditions: 2 (1.0 eq.), $\mathrm{NaHCO}_{3}$ (10.0 eq.), $\mathrm{I}_{2}$ (7.5 eq.) in $\mathrm{THF} / \mathrm{H}_{2} \mathrm{O}(2.5: 1,0.025 \mathrm{M}), \mathrm{RT}, 4 \mathrm{~h}$. b) Isolated yields shown values in parentheses show conversion to product determined by ${ }^{1} \mathrm{H}$ NMR analysis of the crude material against an internal standard. c) Reaction ran in 2.5:1 DMSO/ $\mathrm{H}_{2} \mathrm{O}$ solvent system. d) $\% \mathrm{rsm}=$ percentage of remaining starting material observed by crude ${ }^{1} \mathrm{H}$ NMR. e) Iodine was added in three portions of 2.5 eq. each hour. f) Reaction stirred for $20 \mathrm{~h}$.

sulfonamides. Products 5d and 5e were isolated in low isolated? yields (15\% and 26\%, respectively), and were formed in moderate conversions (56\% and $57 \%$, respectively). This is attributed to formation of other oxidative by-products that were not isolable, in addition to their challenging purification, which required the use of HPLC (see SI), all of which resulted in low recovery of product. The morpholino-lactam $\mathbf{5 f}$ was also produced in $55 \%$ yield with retention of the cis-orientation of the ring-methyl groups. Of particular note was the regioselective oxidation of the asymmetrical azepane ring in $\mathbf{4 g}$, forming lactams $5 \mathrm{~g} \boldsymbol{\alpha}$ and $\mathbf{5 g} \boldsymbol{\beta}$ in a ratio of 4.3:1. These results demonstrate the general chemoselectivity of this methodology for oxidation of cyclic amines in complex small molecules. 

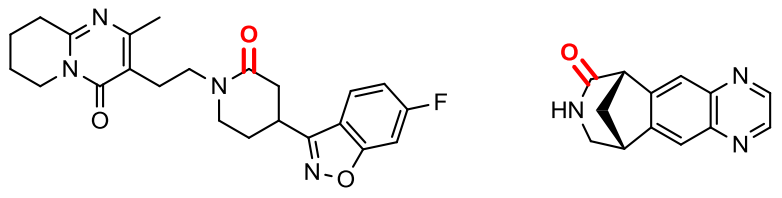<smiles>COc1ccc2c(c1)CCC(c1ccccc1)=C2c1ccc(OCCN2CCCC2=O)cc1</smiles>

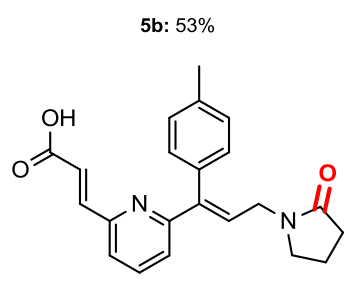

5c: $92 \%$

5d: $15 \%(56 \%)$<smiles>CCCc1nc(C)c2c(=O)[nH]c(-c3cc(S(=O)(=O)N4CCN(CC)C(=O)C4)ccc3OCC)nn12</smiles><smiles>CC(Cc1ccc(C(C)(C)C)cc1)CN1C[C@H](C)O[C@H](C)C1=O</smiles>

5e: $26 \%(57 \%)^{[c]}$

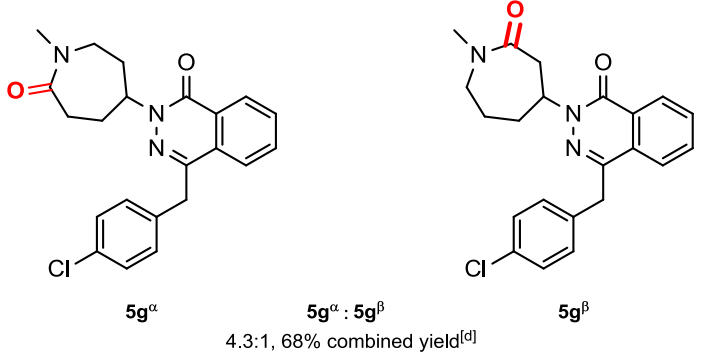

Figure 2. Substrate scope of late-stage $\mathrm{C}-\mathrm{H}$ oxidation of industrially relevant drug scaffolds. ${ }^{[a]}$ Conditions: 4 (1.0 eq.), $\mathrm{NaHCO}_{3}$ (10.0 eq.), $\mathrm{I}_{2}$ (7.5 eq.) in THF/ $\mathrm{H}_{2} \mathrm{O}(2.5: 1,0.025 \mathrm{M}), \mathrm{RT}, 4 \mathrm{~h} .{ }^{[\mathrm{b}]}$ Isolated yields shown - values in parentheses show conversion to product determined by ${ }^{1} \mathrm{H}$ NMR analysis of the crude material against an internal standard. ${ }^{[c]}$ Reaction run in 2.5:1 DMSO/ $\mathrm{H}_{2} \mathrm{O}$ solvent system. ${ }^{[\mathrm{d}]}$ Ratio of products determined by NMR analysis.

When compared to other conditions reported for oxidation of amines directly to amides/lactams ${ }^{[7 \mathrm{~h}, 8,9,13 \mathrm{c}]}$ (Figure 3 ) the conditions developed here offer substantially better chemoselective oxidation when applied to drugs $\mathbf{4 h}$ and $\mathbf{4 i}$ (Condition A), with $\mathbf{5 h}$ isolated in high yield (83\%) and $\mathbf{5 i}$ formed in high conversion $(81 \%)$. Product $5 \mathbf{i}$ could only be isolated in low yield $(30 \%)$ because further purification was required due to co-elution with an iodinated by-product during the first purification (see SI). ${ }^{18} \mathrm{O}$-labelling studies were then undertaken using $\mathrm{Na}^{18} \mathrm{OAc}$ as the base and $\mathrm{H}_{2}{ }^{18} \mathrm{O}$ (See SI). Full ${ }^{18} \mathrm{O}$-incorporation was observed in the conversion of $\mathbf{2 a}$ into ${ }^{18} \mathrm{O}-\mathbf{3 a}$ when $\mathrm{H}_{2}{ }^{18} \mathrm{O} / \mathrm{Na}^{18} \mathrm{OAc}$ was used. In contrast, only 3a was formed using $\mathrm{H}_{2} \mathrm{O} / \mathrm{Na}^{18} \mathrm{OAc}$. This confirmed that the source of the lactam oxygen in the product is derived from water and not from the base. Additionally, ${ }^{1} \mathrm{H}$ NMR experiments were carried out to further probe the mechanism of this reaction (See SI, Table S2). These revealed the formation of an $\mathrm{N}$-iodoammonium intermediate upon addition of iodine (7.5 eq.) to $2 \mathrm{a}$. Dilution of the reaction mixture to $0.025 \mathrm{M}$ with $\mathrm{d}_{8}$-THF and $\mathrm{D}_{2} \mathrm{O}$, followed by the stepwise addition of sodium bicarbonate resulted in full conversion after 2 hours and 5.0 equivalents of base.
Taken collectively, we propose that this reaction proceeds via the initial formation of the charge-transfer complex 6 (Scheme 2a). ${ }^{14}$<smiles>CC1CCN(CCCC(=O)c2ccc(F)cc2)C(=O)C1</smiles>

$5 h$

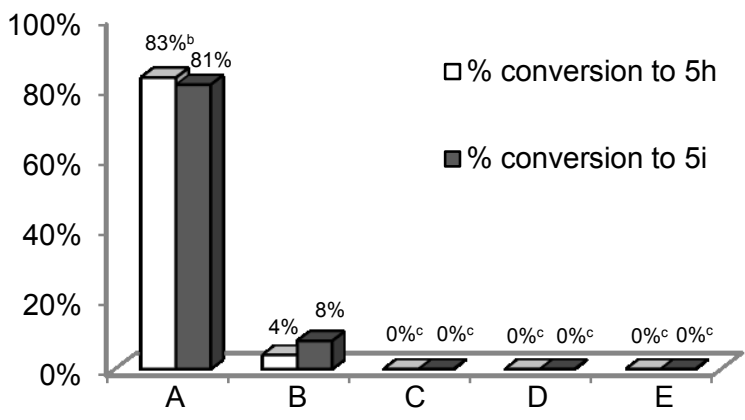

Figure 3. Comparative analysis of amine oxidation conditions using drug compounds $5 \mathrm{~h}$ and $5 \mathrm{i}$ as exemplars. ${ }^{[\mathrm{a}]}$ General conditions: $\mathrm{A}=\mathrm{I}_{2}, \mathrm{NaHCO}_{3}, \mathrm{RT}, 4 \mathrm{~h} ; \mathrm{B}^{8}=1(1 \mathrm{~mol} \%), \mathrm{NaOH}, 150{ }^{\circ} \mathrm{C}, 48 \mathrm{~h}$; $\mathrm{C}^{9}=\mathrm{FeCl}_{3}(5 \mathrm{~mol} \%)$, picolinic acid $\left(5.0 \mathrm{~mol}^{\%}\right), \mathrm{PhCO}_{3}{ }^{\mathrm{t}} \mathrm{Bu}(3.0$ eq.), $\mathrm{H}_{2} \mathrm{O}, 50{ }^{\circ} \mathrm{C}, 24 \mathrm{~h} ; \mathrm{D}^{7 \mathrm{~h}}=\mathrm{RuO}_{2}(10 \mathrm{~mol} \%), \mathrm{NaIO}_{4}$ (6.3 eq.), $\mathrm{RT}, 64 \mathrm{~h} ; \mathrm{E}^{13 \mathrm{c}}=\mathrm{PhI}(\mathrm{OAc})_{2}$ (2.2 eq.), $\mathrm{H}_{2} \mathrm{O}, \mathrm{RT}, 16 \mathrm{~h}$. For detailed conditions see SI. ${ }^{[\mathrm{b}]}$ Isolated yield. ${ }^{[\mathrm{c}]}$ Complex mixture of oxidative by-products observed.

Scheme 2. a) Proposed reaction mechanism, and b) the unexpected cyclization of Naratriptan.

a)

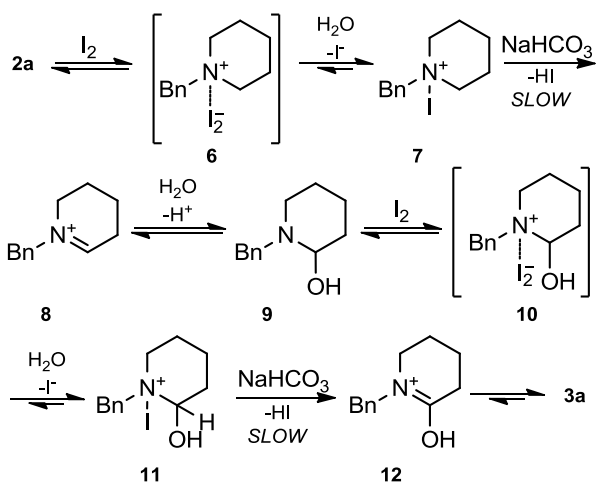

b)<smiles>CNS(=O)(=O)CCc1ccc2[nH]cc(C3CCN(C)CC3)c2c1</smiles>

a) Conditions: 13 (1.0 eq.), $\mathrm{NaHCO}_{3}$ (10.0 eq.), $\mathrm{I}_{2}$ (7.5 eq.) in $\mathrm{THF} / \mathrm{H}_{2} \mathrm{O}(2.5: 1,0.025 \mathrm{M}), \mathrm{RT}, 20 \mathrm{~h}$. b) Isolated yield shown value in parentheses shows conversion to product determined by ${ }^{1} \mathrm{H}$ NMR analysis of the reaction mixture run in deuterated solvents against an internal standard.

With moisture present, this would form 7, followed by slow formation of iminium ion $\mathbf{8}$. The observed endocyclic oxidation 
is most likely due to a more effective anti-periplanar E2-elimination of the N-I and $\mathrm{C}-\mathrm{H} \alpha$ bonds relative to the conformationally flexible exocyclic site. The low basicity of sodium bicarbonate may also be responsible for the selectivity of deprotonation seen for $\mathbf{2} \mathbf{p}$, with the less sterically hindered hydrogen being deprotonated over the more acidic one. Nucleophilic attack by water at the iminium carbon in $\mathbf{8}$ and subsequent deprotonation forms 9 . A second iodination step to form 11 via $\mathbf{1 0}$, enables the formation of $\mathbf{1 2}$ via loss of hydrogen iodide, and tautomerization results in the formation of $\mathbf{3 a}$. The unexpected formation of product $\mathbf{1 4}$ in $52 \%$ conversion from the indole $\mathbf{1 3}$ (Scheme 2b) further underpins the formation of the $\mathrm{N}$-iodoammonium intermediate such as 7 on the piperidine ring, which can be sequestered by the proximal indole in this instance.

In summary, we have developed a mild, late-stage strategy for the chemoselective oxidation of cyclic amines to the corresponding lactams under mild conditions. We envisage that this approach could be generalized by medicinal chemists to create a diverse range of compounds from a small subset of molecular scaffolds, as well as providing synthetic access to drug metabolites, ${ }^{1 e, 15}$ potentially accelerating the hit-to-lead process of drug discovery compared to more traditional linear routes.

\section{ASSOCIATED CONTENT}

\section{Supporting Information}

Experimental details and characterization data is available free of charge on the ACS Publications website.

\section{AUTHOR INFORMATION}

\section{Corresponding Author}

*eric.p.talbot@gsk.com

*glenn.burley@strath.ac.uk

\section{ACKNOWLEDGMENT}

Financial support for this work was provided by GSK via the GSK/University of Strathclyde Centre for Doctoral Training in Synthetic and Medicinal Chemistry. We also thank Stephen Richards and Sean Lynn for their assistance with NMR analysis.

\section{REFERENCES}

(1) For recent reviews on late-stage $C$-H functionalisation, see (a) Cernak, T.; Dykstra, K. D.; Tyagarajan, S.; Vachal, P.; Krska, S. W. Chem. Soc. Rev. 2016, 45 (3), 546; (b) Newhouse, T.; Baran, P. S. Angew. Chemie Int. Ed. 2011, 50 (15), 3362. For recent research on $C$ H oxidation, see: (c) Osberger, T. J.; Rogness, D. C.; Kohrt, J. T.; Stepan, A. F.; White, M. C. Nature 2016, 537 (7619), 214; (d) Howell, J. M.; Feng, K.; Clark, J. R.; Trzepkowski, L. J.; White, M. C. J. Am. Chem. Soc. 2015, 137 (46), 14590; (e) Genovino, J.; Lütz, S.; Sames, D.; Touré, B. B. J. Am. Chem. Soc. 2013, 135 (33), 12346; (f) Mbofana, C. T.; Chong, E.; Lawniczak, J.; Sanford, M. S. Org. Lett. 2016, 18 (17), 4258; (g) Lee, M.; Sanford, M. S. J. Am. Chem. Soc. 2015, 137 (40), 12796; (h) Sun, S.-Z.; Shang, M.; Wang, H.-L.; Lin, H.-X.; Dai, H.-X.; Yu, J.-Q. J. Org. Chem. 2015, 80 (17), 8843; (i) Zhang, Y. H.; Yu, J. Q. J. Am. Chem. Soc. 2009, 131 (41), 14654; (j) See, Y. Y.; Herrmann, A. T.; Aihara, Y.; Baran, P. S. J. Am. Chem. Soc. 2015, 137 (43), 13776; (k) Horn, E. J.; Rosen, B. R.; Chen, Y.; Tang, J.; Chen, K.; Eastgate, M. D.; Baran, P. S. Nature 2016, 533 (7601), 77; (1)
McNeill, E.; Du Bois, J. Chem. Sci. 2012, 3 (6), 1810; (m) Adams, A. M.; Du Bois, J. Chem. Sci. 2014, 5 (2), 656.

(2) (a) Toyooka, N.; Nemoto, H. In Studies in Natural Products Chemistry; Atta-ur-Rahman, Ed.; Elsevier B.V., 2003; pp 419; (b) Guntern, A.; Ioset, J.-R.; Queiroz, E. F.; Sándor, P.; Foggin, C. M.; Hostettmann, K. J. Nat. Prod. 2003, 66 (12), 1550.

(3) (a) Drawz, S. M.; Bonomo, R. A. Clin. Microbiol. Rev. 2010, 23 (1), 160; (b) Kazmierski, W. M.; Andrews, W.; Furfine, E.; Spaltenstein, A.; Wright, L. Bioorg. Med. Chem. Lett. 2004, 14 (22), 5689, (c) Enz, A.; Feuerbach, D.; Frederiksen, M. U.; Gentsch, C.; Hurth, K.; Müller, W.; Nozulak, J.; Roy, B. L. Bioorg. Med. Chem. Lett. 2009, 19 (5), 1287, (d) Shorvon, S. Lancet 2001, 358 (9296), 1885.

(4) Hari, Y.; Osawa, T.; Kotobuki, Y.; Yahara, A.; Shrestha, A. R.; Obika, S. Bioorg. Med. Chem. 2013, 21 (14), 4405.

(5) Bailey, P. D.; Collier, I. D.; Morgan, K. M. In Comprehensive Organic Functional Group Transformations; Moody, C. J., Ed.; Pergamon: Oxford, 1995; pp 257

(6) (a) Naota, T.; Murahashi, S.-I. Synlett 1991, No. 10, 693; (b) Gunanathan, C.; Ben-David, Y.; Milstein, D. Science 2007, 317 (5839), 790.

(7) (a) Al-Subu, M. M.; Jondi, W. J.; Amer, A. A.; Hannoun, M.; Musmar, M. J. Chem. Heterocycl. Compd. 2003, 39 (4), 478; (b) Wenkert, E.; Angell, E. C. Synth. Commun. 1988, 18 (12), 1331; (c) Wei, Y.; Ding, H.; Lin, S.; Liang, F. Org. Lett. 2011, 13 (7), 1674; (d) Rao, G.; Periasamy, M. Synlett 2015, 26 (16), 2231; (e) Yan, X.; Fang, K.; Liu, H.; Xi, C. Chem. Commun. 2013, 49 (90), 10650; (f) Tanaka, K.-I.; Yoshifuji, S.; Nitta, Y. Chem. Pharm. Bull. 1988, 36 (8), 3125; (g) Sheehan, J. C.; Tulis, R. W. J. Org. Chem. 1974, 39 (15), 2264; (h) Breault, G.; Eyermann, C. J.; Geng, B.; Morningstar, M.; Reck, F. Compounds for the Treatment of Multi-Drug Resistant Bacterial Infections. WO2006134378 (A1), 2006.

(8) Khusnutdinova, J. R.; Ben-David, Y.; Milstein, D. J. Am. Chem. Soc. 2014, $136(8), 2998$.

(9) Legacy, C. J.; Wang, A.; O’Day, B. J.; Emmert, M. H. Angew. Chemie Int. Ed. 2015, 54 (49), 14907.

(10) Jin, X.; Kataoka, K.; Yatabe, T.; Yamaguchi, K.; Mizuno, N. Angew. Chemie 2016, 128 (25), 7328.

(11) (a) Yusubov, M. S.; Zhdankin, V. V. Resour. Technol. 2015, 1 (1), 49; (b) Li, J.; Lear, M. J.; Kawamoto, Y.; Umemiya, S.; Wong, A. R.; Kwon, E.; Sato, I.; Hayashi, Y. Angew. Chemie Int. Ed. 2015, 54 (44), 12986; (c) Li, J.; Lear, M. J.; Kwon, E.; Hayashi, Y. Chem. Eur. J. 2016, 22 (16), 5538; (d) Liang, Y.-F.; Li, X.; Wang, X.; Zou, M.; Tang, C.; Liang, Y.; Song, S.; Jiao, N. J. Am. Chem. Soc. 2016, 138 (37), 12271.

(12) (a) Kutney, J. P.; Balsevich, J.; Honda, T.; Liao, P.-H.; Thiellier, H. P. M.; Worth, B. R. Can. J. Chem. 1978, 56 (19), 2560; (b) Langlois, N.; Andriamialisoa, R. Z.; Neuss, N. Helv. Chim. Acta 1980, 63 (4), 793.

(13) (a) Moriarty, R. M.; Vaid, R. K.; Duncan, M. P.; Ochiai, M.; Inenaga, M.; Nagao, Y. Tetrahedron Lett. 1988, 29 (52), 6913; (b) de Graaff, C.; Bensch, L.; van Lint, M. J.; Ruijter, E.; Orru, R. V. A. Org. Biomol. Chem. 2015, 13 (40), 10108; (c) Waghmode, N. A.; Kalbandhe, A. H.; Thorat, P. B.; Karade, N. N. Tetrahedron Lett. 2016, 57 (6), 680; (d) Castro -C., A.; Juárez -P., J.; Gnecco, D.; Terán, J. L.; Galindo, A.; Bernès, S.; Enríquez, R. G. Tetrahedron: Asymmetry 2005, 16 (5), 949; (e) R. Juárez, J.; Castro, A.; Romero, O.; L. Terán, J.; Gnecco, D.; Orea, L.; Mendoza, A. Heterocycles 2014, 89 (3), 725.

(14) Nagakura, S. J. Am. Chem. Soc. 1957, 80 (9), 520; (b) Yada, H.; Tanaka, J.; Nagakura, S. Bull. Chem. Soc. Jpn. 1960, 33 (12), 1660.

(15) (a) Genovino, J.; Sames, D.; Touré, B. B. Tetrahedron Lett. 2015, 56 (23), 3066; (b) Genovino, J.; Sames, D.; Hamann, L. G.; Touré, B. B. Angew. Chemie Int. Ed. 2016, 55 (46), 14218. 


\title{
Transition Metal-Free Amine Oxidation: a Chemoselective Strategy for the Late-Stage Formation of Lactams
}

\author{
Robert J. Griffiths ${ }^{\dagger \ddagger}$, Glenn A. Burley ${ }^{\ddagger *}$, Eric P.A. Talbot ${ }^{\dagger *}$ \\ † GlaxoSmithKline Medicines Research, Gunnels Wood Road, Stevenage, Hertfordshire, SG1 \\ 2NY, UK \\ eric.p.talbot@gsk.com \\ $\ddagger$ Department of Pure and Applied Chemistry, University of Strathclyde, 295 Cathedral \\ Street, Glasgow, G1 1XL \\ glenn.burley@strath.ac.uk
}

\section{Table of Contents}

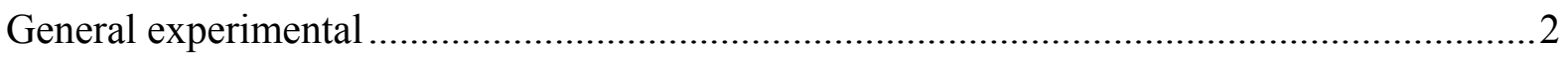

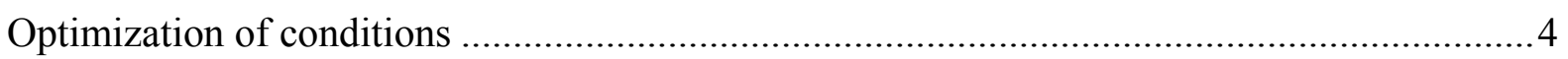

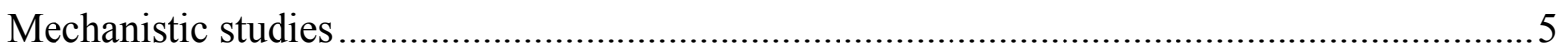

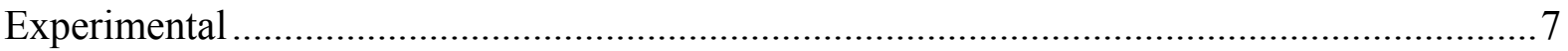

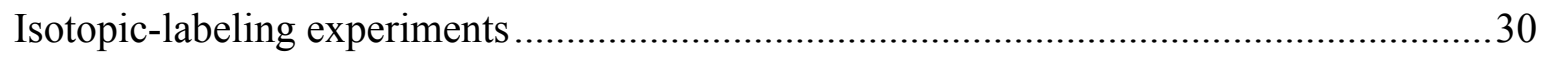

Investigating late-stage oxidation under Milstein conditions ..................................... 3231

Investigating late-stage oxidation under Emmert conditions.......................................32 34

Investigating late-stage oxidation under classical RuIVO2/NaIO4 conditions ...............32 31

Investigating late-stage oxidation under hypervalent iodine conditions.........................3332

NMR Spectra of synthesized compounds .................................................................. 3433

Crude ${ }^{1} \mathrm{H}$ NMR spectra of selected entries during optimization and mechanistic studies

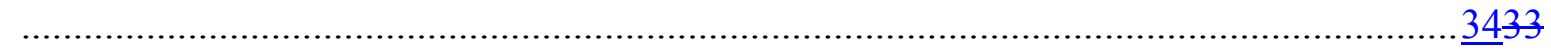

${ }^{1} \mathrm{H}$ NMR spectra of selected crude substrates determining NMR conversions ................

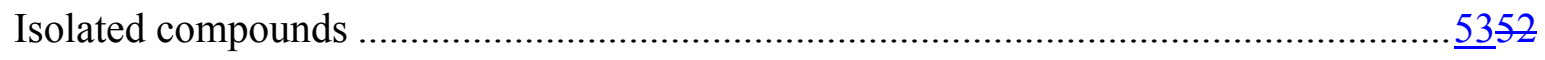

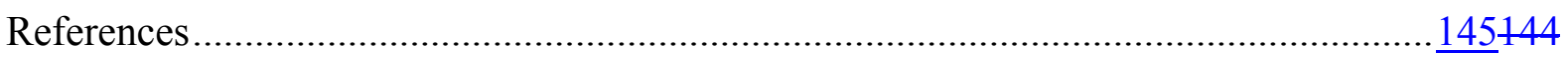




\section{General experimental}

\section{Solvents and reagents}

Unless otherwise stated:

- Reactions were carried out under a standard atmosphere of air at room temperature, and glassware was not dried beforehand. Solvents used were non-anhydrous.

- Solvents and reagents were purchased from commercial suppliers or obtained from GlaxoSmithKline's internal compound storage and used as received without further purification. All drug compounds used in transformations are commercially available.

- Reactions were monitored by liquid chromatography-mass spectroscopy (LCMS) and Nuclear Magnetic Resonance (NMR).

Where substrates were synthesized in-house, literature references are given for spectral data of these compounds.

\section{Chromatography}

Thin layer chromatography (TLC) was carried out using plastic-backed 50 precoated silica plates (particle size $0.2 \mathrm{~mm}$ ). Spots were visualized by ultraviolet (UV) light $\left(\lambda_{\max }=254 \mathrm{~nm}\right.$ or $365 \mathrm{~nm}$ ) and then stained with potassium permanganate solution followed by gentle heating. Silica gel chromatography was carried out using the Teledyne ISCO CombiFlash ${ }^{\circledR}$ $\mathrm{Rf}+$ apparatus with RediSep ${ }^{\circledR}$ silica cartridges. Reverse phase preparative HPLC was carried out using the Grace Reveleris ${ }^{\circledR}$ Prep apparatus with an XTerra ${ }^{\circledR}$ Prep $\mathrm{RP}_{18} \mathrm{OBD}^{\mathrm{TM}}$ column.

\section{Liquid chromatography mass spectrometry (LCMS)}

LCMS analysis was carried out on an $\mathrm{H}_{2} \mathrm{Os}$ Acquity UPLC instrument equipped with a BEH column $\left(50 \mathrm{~mm}\right.$ x $2.1 \mathrm{~mm}, 1.7 \mu \mathrm{m}$ packing diameter) and $\mathrm{H}_{2} \mathrm{Os}$ micromass ZQ MS using alternate-scan positive and negative electrospray. Analytes were detected as a summed UV wavelength of $210-350 \mathrm{~nm}$. Two liquid phase methods were used: was a high $\mathrm{pH}$ method:

Method A - High pH $-40{ }^{\circ} \mathrm{C}, 1 \mathrm{~mL} / \mathrm{min}$ flow rate. Gradient elution with the mobile phases as (A) $10 \mathrm{mM}$ aqueous ammonium bicarbonate solution, adjusted to $\mathrm{pH} 10$ with $0.88 \mathrm{M}$ aqueous ammonia and (B) acetonitrile. Gradient conditions were initially $1 \% \mathrm{~B}$, increasing linearly to $97 \% \mathrm{~B}$ over $1.5 \mathrm{~min}$, remaining at $97 \% \mathrm{~B}$ for $0.4 \mathrm{~min}$ then increasing to $100 \% \mathrm{~B}$ over $0.1 \mathrm{~min}$.

Method B - Low pH $-40{ }^{\circ} \mathrm{C}, 1 \mathrm{~mL} / \mathrm{min}$ flow rate. Gradient elution with the mobile phases as (A) $\mathrm{H}_{2} \mathrm{O}$ containing $0.1 \%$ volume/volume (v/v) formic acid and (B) acetonitrile containing $0.1 \%(\mathrm{v} / \mathrm{v})$ formic acid. Gradient conditions were initially $1 \%$ $\mathrm{B}$, increasing linearly to $97 \% \mathrm{~B}$ over $1.5 \mathrm{~min}$, remaining at $97 \% \mathrm{~B}$ for $0.4 \mathrm{~min}$ then increasing to $100 \% \mathrm{~B}$ over $0.1 \mathrm{~min}$.

\section{Nuclear magnetic resonance (NMR) spectroscopy}

Proton $\left({ }^{1} \mathrm{H}\right)$ and carbon $\left({ }^{13} \mathrm{C}\right)$ spectra were recorded in deuterated solvents at ambient temperature using standard pulse methods on any of the following spectrometers and signal frequencies: Bruker AV-400 $\left({ }^{1} \mathrm{H}=400 \mathrm{MHz},{ }^{13} \mathrm{C}=101 \mathrm{MHz}\right)$, Bruker AV-500 $\left({ }^{1} \mathrm{H}=500\right.$ $\left.\mathrm{MHz},{ }^{13} \mathrm{C}=126 \mathrm{MHz}\right)$ and Bruker AV-600 $\left({ }^{1} \mathrm{H}=600 \mathrm{MHz},{ }^{13} \mathrm{C}=151 \mathrm{MHz}\right)$. Chemical shifts are reported in ppm and are referenced to the following solvent peaks: $\mathrm{CDCl}_{3}\left({ }^{1} \mathrm{H}=\right.$ 
$\left.7.27 \mathrm{ppm},{ }^{13} \mathrm{C}=77.0 \mathrm{ppm}\right), d_{6}$-DMSO $\left({ }^{1} \mathrm{H}=2.50 \mathrm{ppm},{ }^{13} \mathrm{C}=39.5 \mathrm{ppm}\right)$, and $\mathrm{D}_{2} \mathrm{O}\left({ }^{1} \mathrm{H}=4.79\right.$ $\mathrm{ppm})$. Where $\mathrm{D}_{2} \mathrm{O}$ was used as the solvent, the default referencing was used based on the $\mathrm{D}_{2} \mathrm{O}$ lock frequency for ${ }^{13} \mathrm{C}$ NMR. Peak assignments were made on the basis of chemical shifts, integrations, and coupling constants using COSY, DEPT, HSQC, HMBC, NOESY and ROESY where appropriate. Coupling constants are quoted to the nearest $0.01 \mathrm{~Hz}$ and multiplicities are described as singlet (s), doublet (d), triplet (t), quartet (q), quintet (quin), sextet (sxt), br. (broad) and multiplet (m).

\section{Infrared (IR) spectroscopy}

IR spectra were recorded using a Perkin Elmer Spectrum 1 machine. Absorption maxima $\left(v_{\max }\right)$ are reported in wavenumbers $\left(\mathrm{cm}^{-1}\right)$.

\section{Mass directed automated preparation (MDAP)}

MDAP was carried out using an $\mathrm{H}_{2} \mathrm{Os}$ ZQ MS using alternate-scan positive and negative electrospray and a summed UV wavelength of 210-350 $\mathrm{nm}$. liquid phase method used was a high $\mathrm{pH}$ method:

Xbridge C18 column (100 mm x $19 \mathrm{~mm}, 5 \mu \mathrm{m}$ packing diameter, $20 \mathrm{~mL} / \mathrm{min}$ flow rate) or Xbridge C18 column (150 mm x $30 \mathrm{~mm}, 5 \mu \mathrm{m}$ packing diameter, $40 \mathrm{~mL} / \mathrm{min}$ flow rate). Gradient elution at ambient temperature with the mobile phases as (A) 10 $\mathrm{mM}$ aqueous ammonium bicarbonate solution, adjusted to $\mathrm{pH} 10$ with $0.88 \mathrm{M}$ aqueous ammonia and (B) acetonitrile.

The elution gradients used were at a flow rate of $40 \mathrm{~mL} / \mathrm{min}$ over 20 or $30 \mathrm{~min}$ depending on separation:

\begin{tabular}{|l|c|}
\hline Gradient A & $5-30 \% \mathrm{~B}$ \\
\hline Gradient B & $15-55 \% \mathrm{~B}$ \\
\hline Gradient C & $30-85 \% \mathrm{~B}$ \\
\hline Gradient D & $50-99 \% \mathrm{~B}$ \\
\hline Gradient E & $80-99 \% \mathrm{~B}$ \\
\hline
\end{tabular}




\section{Optimization of conditions}

Table S1: Optimization of iodine-mediated oxidation with $N$-benzylpiperidine $2 a^{[a]}$

\begin{tabular}{|c|c|c|c|c|}
\hline Entry & Eq. of $\mathbf{I}_{2}$ & Solvent system & $\begin{array}{c}\text { Concentration of } \\
2 \mathrm{a} / \mathrm{M}\end{array}$ & Conversion $^{[b]}$ to $3 a(\%)$ \\
\hline 1 & 10 & Toluene $/ \mathrm{H}_{2} \mathrm{O}(2.5: 1)$ & 0.025 & $\mathrm{nr}$ \\
\hline 2 & 10 & $\mathrm{DCM} / \mathrm{H}_{2} \mathrm{O}(2.5: 1)$ & 0.025 & $\mathrm{nr}$ \\
\hline 3 & 10 & $\mathrm{MeOH} / \mathrm{H}_{2} \mathrm{O}(2.5: 1)$ & 0.025 & 5 \\
\hline 4 & 10 & $\mathrm{HFIP}^{[\mathrm{c}]} / \mathrm{H}_{2} \mathrm{O}(2.5: 1)$ & 0.025 & 2 \\
\hline 5 & 10 & $\mathrm{H}_{2} \mathrm{O}$ & 0.025 & 6 \\
\hline 6 & 10 & $\mathrm{MeCN} / \mathrm{H}_{2} \mathrm{O}(2.5: 1)$ & 0.025 & 6 \\
\hline 7 & 10 & $\mathrm{THF} / \mathrm{H}_{2} \mathrm{O}(2.5: 1)$ & 0.025 & 91 \\
\hline 8 & 10 & $\mathrm{DMSO} / \mathrm{H}_{2} \mathrm{O}(2.5: 1)$ & 0.025 & 90 \\
\hline 9 & 10 & $\mathrm{THF} / \mathrm{H}_{2} \mathrm{O}(2.5: 1)$ & $0.1^{[\mathrm{d}]}$ & 59 \\
\hline 10 & 10 & $\mathrm{THF} / \mathrm{H}_{2} \mathrm{O}(2.5: 1)$ & $0.05^{[\mathrm{d}]}$ & 57 \\
\hline 11 & 1.1 & $\mathrm{THF} / \mathrm{H}_{2} \mathrm{O}(2.5: 1)$ & 0.025 & 15 \\
\hline 12 & 2.5 & $\mathrm{THF} / \mathrm{H}_{2} \mathrm{O}(2.5: 1)$ & 0.025 & 31 \\
\hline 13 & 5.0 & $\mathrm{THF} / \mathrm{H}_{2} \mathrm{O}(2.5: 1)$ & 0.025 & 68 \\
\hline 14 & 7.5 & $\mathrm{THF} / \mathrm{H}_{2} \mathrm{O}(2.5: 1)$ & 0.025 & $96^{[\mathrm{d} e]}$ \\
\hline 15 & $7.5^{[\mathrm{ef}]}$ & $\mathrm{THF} / \mathrm{H}_{2} \mathrm{O}(2.5: 1)$ & 0.025 & 62 \\
\hline $16^{[\mathrm{fg}]}$ & 7.5 & $\mathrm{THF} / \mathrm{H}_{2} \mathrm{O}(2.5: 1)$ & 0.025 & $\mathrm{nr}$ \\
\hline 17 & 7.5 & THF & 0.025 & $\mathrm{nr}$ \\
\hline $18^{[\mathrm{gh}]}$ & 7.5 & $\mathrm{THF} / \mathrm{H}_{2} \mathrm{O}(2.5: 1)$ & 0.025 & $\begin{array}{l}\text { No change in reaction } \\
\text { profile by LCMS - no } \\
\text { yield gathered }\end{array}$ \\
\hline
\end{tabular}

${ }^{[\mathrm{a}]}$ Reaction conditions: $2 \mathrm{a}$ (1.0 eq.), $\mathrm{NaHCO}_{3}$ (10.0 eq.), $\mathrm{I}_{2}(1.1-10.0$ eq.) in solvent stirred at room temperature for $4 \mathrm{~h}$; ${ }^{[b]}$ Conversion determined by ${ }^{1} \mathrm{H}$ NMR analysis of crude material against an internal standard; ${ }^{[c]}$ HFIP $=1,1,1,3,3,3$-hexafluoroisopropanol; ${ }^{[\mathrm{d}]}$ At higher concentrations of $\mathbf{2 a}$, formation of alpha -iodolactam by-products was observed; ${ }^{\text {[de] }}$ Isolated yield; ${ }^{[e f]} \mathrm{N}$-iodosuccinimide used as the iodine source instead of $\mathrm{I}_{2} ;{ }^{[\mathrm{fg}]} \mathrm{No} \mathrm{NaHCO}_{3}$ present; [sh] Reaction carried out under a nitrogen atmosphere. 


\section{$\underline{\text { Mechanistic studies }}$}

Table S2: NMR studies into mechanism of oxidation ${ }^{[a]}$

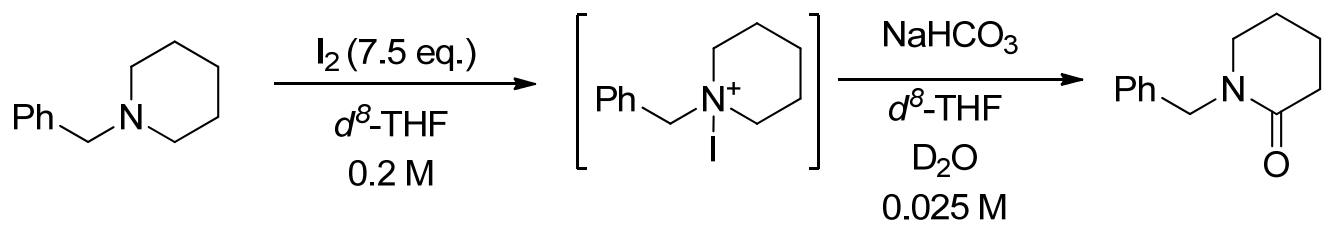

$2 a$

7

$3 a$

\begin{tabular}{|c|c|c|c|}
\hline Entry & Eq. $\mathrm{NaHCO}_{3}$ & Time / min & $\begin{array}{c}\text { Ratio of } \\
\mathbf{2 a : 8 : 3 a}\end{array}$ \\
\hline 1 & 0.0 & 0 & $0: 1: 0$ \\
\hline 2 & 1.0 & 30 & $0: 1: 0$ \\
\hline 3 & 2.0 & 60 & $0: 1.53: 1$ \\
\hline 4 & 3.0 & 90 & $0: 0.56: 1$ \\
\hline 5 & 5.0 & 120 & $0: 0: 1$ \\
\hline 6 & 8.0 & 240 & $0: 0: 1$ \\
\hline 7 & 10.0 & 360 & $0: 0: 1$ \\
\hline
\end{tabular}

${ }^{\text {[a] }}$ Reaction conditions: $2 \mathrm{a}(0.57 \mathrm{mmol})$ was added to a solution of iodine $(4.28 \mathrm{mmol})$ in $d^{8}$ THF $(2.9 \mathrm{~mL})$. This reaction mixture was stirred at RT for $1.5 \mathrm{~h}$, and ${ }^{1} \mathrm{H}$ NMR analysis showed conversion of $\mathbf{2 a}$ to 7 . A $1 \mathrm{~mL}$ aliquot of this $0.2 \mathrm{M}$ solution of 7 in $d^{8}$-THF $(0.2$ mmol) was diluted to $0.025 \mathrm{M}$ with $d^{8}$-THF $(4.7 \mathrm{~mL})$ and $\mathrm{D}_{2} \mathrm{O}(2.3 \mathrm{~mL})$. Solid $\mathrm{NaHCO}_{3}$ was added portionwise, as described in Table $\mathrm{S} 2$, and the reaction mixture was monitored by ${ }^{1} \mathrm{H}$ NMR, analyzing conversion of intermediate 7 to product $\mathbf{3 a}$. 


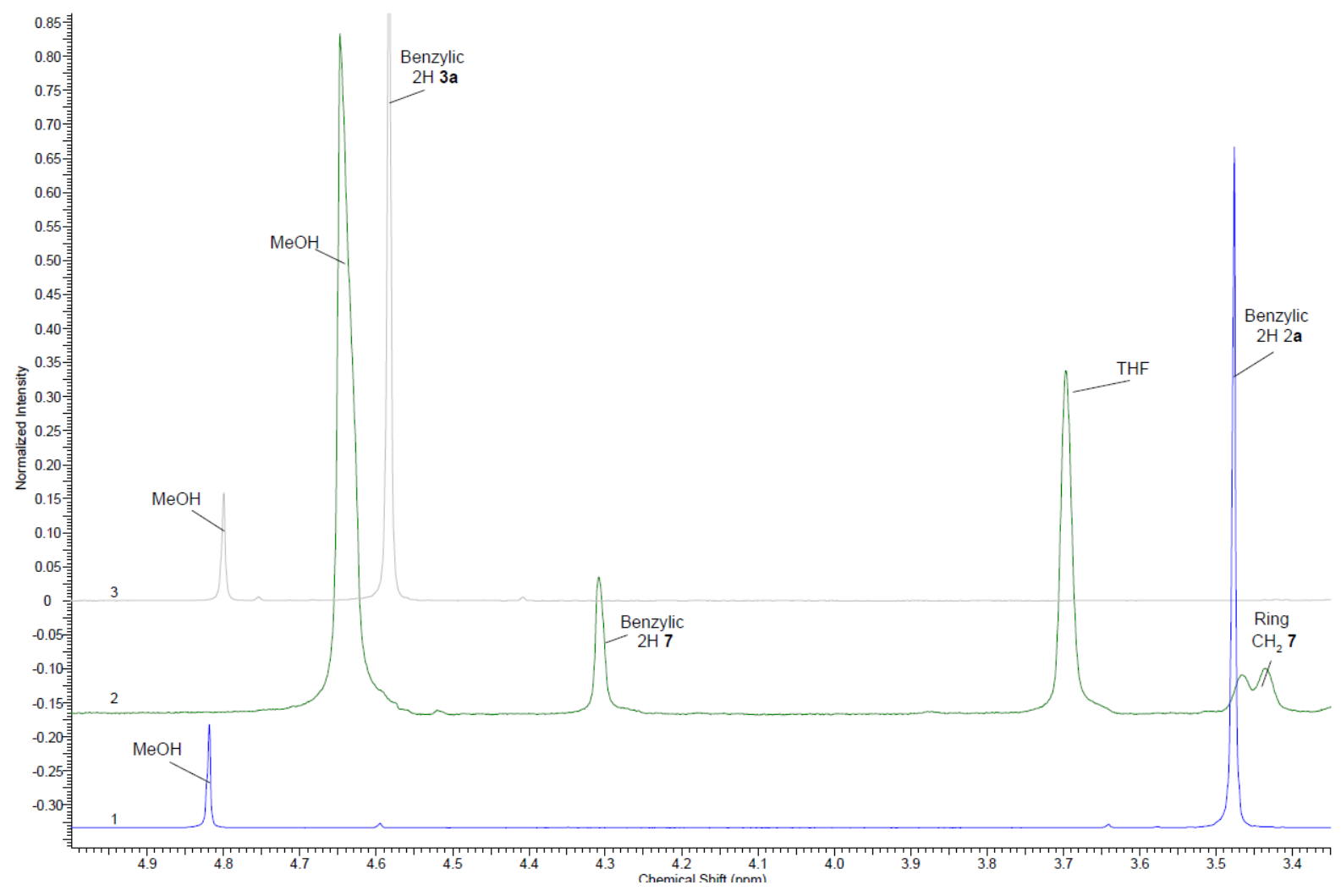

Figure S1: Identification of the proposed intermediate 7. A change in the chemical shift of the benzylic protons of 2a was observed that was typical in difference between an amine and an ammonium species. ${ }^{[1]}$ Also no signal attributable to an iminium ion species was observed. $^{[2]}$

Spectrum 1 (blue): $\mathbf{2 a}$

Spectrum 2 (green): 7

Spectrum 3 (grey): $\mathbf{3 a}$ 


\section{Experimental}

\section{General procedure A}

Iodine (7.5 eq.) was added to a mixture of cyclic amine (1.0 eq.) and sodium bicarbonate (10.0 eq.) in $\mathrm{THF} / \mathrm{H}_{2} \mathrm{O}(2.5: 1,0.025 \mathrm{M})$. The reaction mixture was stirred gently at room temperature for $4 \mathrm{~h}$ and monitored by LCMS. The reaction mixture was then pipetted into a solution of saturated aqueous sodium thiosulfate $(10 \mathrm{~mL})$ and saturated aqueous sodium bicarbonate $(10 \mathrm{~mL})$. The crude material was extracted in DCM $(2 \times 10 \mathrm{~mL})$, and the combined organic layers were washed with saturated aqueous sodium bicarbonate $(10 \mathrm{~mL})$, passed through a hydrophobic frit, concentrated in vacuo and then purified as described.

\section{General procedure B}

Iodine (7.5 eq.) was added to a mixture of cyclic amine (1.0 eq.) and sodium bicarbonate (10.0 eq.) in $\mathrm{DMSO} / \mathrm{H}_{2} \mathrm{O}(2.5: 1,0.025 \mathrm{M})$. The reaction mixture was stirred gently at room temperature for $4 \mathrm{~h}$ and monitored by LCMS. The reaction mixture was then pipetted into a solution of saturated aqueous sodium thiosulfate $(10 \mathrm{~mL})$ and saturated aqueous sodium bicarbonate $(10 \mathrm{~mL})$. The crude material was extracted in DCM $(2 \times 10 \mathrm{~mL})$, and the combined organic layers were washed with saturated aqueous sodium bicarbonate $(10 \mathrm{~mL})$, passed through a hydrophobic frit, concentrated in vacuo and then purified as described.

\section{General procedure $\mathbf{C}$}

Iodine (7.5 eq.) was added to a mixture of cyclic amine (1.0 eq.) and sodium bicarbonate (10.0 eq.) in $\mathrm{THF} / \mathrm{H}_{2} \mathrm{O}(2.5: 1,0.025 \mathrm{M})$. The reaction mixture was stirred gently at room temperature for $20 \mathrm{~h}$ and monitored by LCMS. The reaction mixture was then pipetted into a solution of saturated aqueous sodium thiosulfate $(10 \mathrm{~mL})$ and saturated aqueous sodium bicarbonate $(10 \mathrm{~mL})$. The crude material was extracted in DCM $(2 \times 10 \mathrm{~mL})$, and the combined organic layers were washed with saturated aqueous sodium bicarbonate $(10 \mathrm{~mL})$, passed through a hydrophobic frit, concentrated in vacuo and then purified as described. 


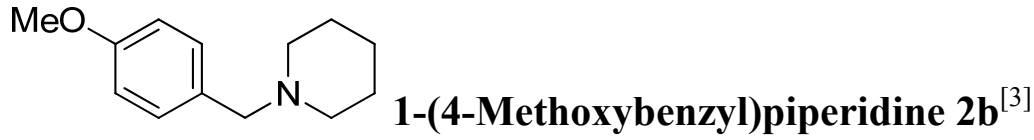

Piperidine $(0.54 \mathrm{~mL}, 5.5 \mathrm{mmol})$, 4-methoxybenzyl chloride $(0.68 \mathrm{~mL}, 5.0 \mathrm{mmol})$ and potassium carbonate $(0.83 \mathrm{~g}, 6.0 \mathrm{mmol})$ were heated to $55^{\circ} \mathrm{C}$ in $\mathrm{MeCN}(20 \mathrm{~mL})$ for $42 \mathrm{~h}$. The reaction mixture was cooled to RT, and then passed through a sintered funnel and the filtrate was concentrated in vacuo. The crude material was purified by silica gel chromatography, with $25-80 \%$ TBME $\quad(5 \%$ methanol, $2 \%$ triethylamine modifier)/cyclohexane, to afford $\mathbf{2 b}(0.64 \mathrm{~g}, 63 \%)$ as a colorless oil.

LCMS (High pH, UV, ESI) $\mathrm{R}_{\mathrm{t}}=1.11 \mathrm{~min},[\mathrm{M}+\mathrm{H}]^{+} 206.1$

${ }^{1} \mathrm{H} \mathrm{NMR}\left(\mathrm{CDCl}_{3}, 400 \mathrm{MHz}\right): \delta 7.23(\mathrm{~d}, J=8.6 \mathrm{~Hz}, 2 \mathrm{H}), 6.86(\mathrm{~d}, J=8.8 \mathrm{~Hz}, 2 \mathrm{H}), 3.81(\mathrm{~s}, 3 \mathrm{H})$, 3.42 (s, 2H), 2.37 (br. s., $4 \mathrm{H}$ ), 1.58 (quin, $J=5.6 \mathrm{~Hz}, 4 \mathrm{H}$ ), 1.44 (br. s, $2 \mathrm{H}$ ).

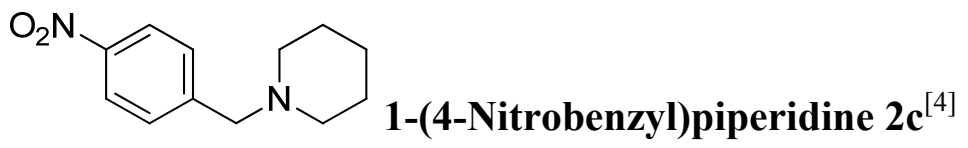

4-nitrobenzyl bromide $(1.19 \mathrm{~g}, 5.5 \mathrm{mmol})$ was slowly added to a solution of piperidine $(0.49$ $\mathrm{mL}, 5.0 \mathrm{mmol})$ and DIPEA $(1.31 \mathrm{~mL}, 7.5 \mathrm{mmol})$ in DCM $(25 \mathrm{~mL})$ at $0{ }^{\circ} \mathrm{C}$. After the addition was complete, the solution was left to stir at RT for $18 \mathrm{~h}$. The reaction mixture was then washed with distilled water $(20 \mathrm{~mL})$ and brine $(20 \mathrm{~mL})$, and the organic layer was passed through a hydrophobic frit and concentrated in vacuo. The crude material was purified by silica gel chromatography with $10-45 \%$ EtOAc/cyclohexane as the eluent, to afford $2 \mathbf{c}(0.98$ g, $89 \%$ ) as a yellow oil.

LCMS (High pH, UV, ESI) $\mathrm{R}_{\mathrm{t}}=1.22 \mathrm{~min},[\mathrm{M}+\mathrm{H}]^{+} 221.1$

${ }^{1} \mathrm{H} \mathrm{NMR}\left(\mathrm{CDCl}_{3}, 400 \mathrm{MHz}\right): \delta 8.13(\mathrm{~d}, J=8.6 \mathrm{~Hz}, 2 \mathrm{H}), 7.48(\mathrm{~d}, J=8.6 \mathrm{~Hz}, 2 \mathrm{H}), 3.52(\mathrm{~s}, 2 \mathrm{H})$, 2.36 (t, $J=5.3 \mathrm{~Hz}, 4 \mathrm{H}$ ), 1.56 (quin, $J=5.6 \mathrm{~Hz}, 4 \mathrm{H}), 1.41-1.46$ (m, $J=5.6 \mathrm{~Hz}, 2 \mathrm{H}$ ).<smiles>c1ccc(CN2CCc3ccccc3C2)cc1</smiles>

\section{2-Benzyl-1,2,3,4-tetrahydroisoquinoline $2 \mathrm{~d}^{[5]}$}

2-picoline borane $(1.05 \mathrm{~g}, 9.8 \mathrm{mmol})$ was added over $5 \mathrm{~min}$ to a mixture of benzaldehyde (1.0 $\mathrm{mL}, 9.8 \mathrm{mmol}), 1,2,3,4$-tetrahydroquinoline $(1.2 \mathrm{~mL}, 9.8 \mathrm{mmol})$ and acetic acid $(0.3 \mathrm{~mL})$ and the reaction mixture stirred at RT for $72 \mathrm{~h}$. The reaction was quenched with $10 \%$ aqueous $\mathrm{HCl}(10 \mathrm{~mL})$ was added and the aqueous solution was stirred for $30 \mathrm{~min}$ at RT. The solution was then made alkaline to $\mathrm{pH} 9$ with saturated aqueous sodium bicarbonate. The aqueous layer was extracted with EtOAc $(2 \times 30 \mathrm{~mL})$, and the combined organic layers were washed with brine $(15 \mathrm{~mL})$, passed through a hydrophobic frit and concentrated in vacuo. The crude product was purified by silica gel chromatography with $0-50 \%$ EtOAc $(1 \% 4 \mathrm{M}$ ammonia/methanol modifier)/cyclohexane as the eluent, to afford $\mathbf{2 d}(2.08 \mathrm{~g}, 94 \%)$ as a colorless oil.

LCMS (High pH, UV, ESI) $\mathrm{R}_{\mathrm{t}}=1.32 \mathrm{~min},[\mathrm{M}+\mathrm{H}]^{+} 224.1$ 
${ }^{1} \mathrm{H}$ NMR $\left(\mathrm{CDCl}_{3}, 400 \mathrm{MHz}\right): \delta 7.50(\mathrm{~d}, J=7.1 \mathrm{~Hz}, 2 \mathrm{H}), 7.40-7.46(\mathrm{~m}, 2 \mathrm{H}), 7.36(\mathrm{tt}, J=7.1,2.3$ $\mathrm{Hz}, 1 \mathrm{H}), 7.16-7.22(\mathrm{~m}, 3 \mathrm{H}), 7.07(\mathrm{~s}, 1 \mathrm{H}), 3.78(\mathrm{~s}, 2 \mathrm{H}), 3.74(\mathrm{~s}, 2 \mathrm{H}), 3.00(\mathrm{t}, J=5.8 \mathrm{~Hz}, 2 \mathrm{H})$, $2.84(\mathrm{t}, J=6.1 \mathrm{~Hz}, 2 \mathrm{H})$.

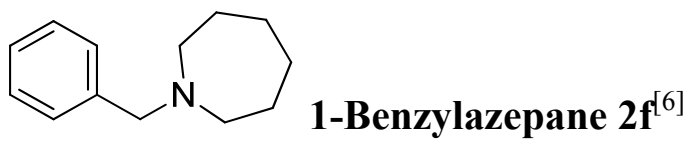

2-picoline borane $(0.83 \mathrm{~g}, 8.3 \mathrm{mmol})$ was added over $5 \mathrm{~min}$ to a mixture of benzaldehyde $(0.85 \mathrm{~mL}, 8.3 \mathrm{mmol})$, azepane $(0.94 \mathrm{~mL}, 8.3 \mathrm{mmol})$ and acetic acid $(0.3 \mathrm{~mL})$ and the reaction mixture stirred at RT for $72 \mathrm{~h}$. The reaction was quenched with $10 \%$ aqueous $\mathrm{HCl}(10 \mathrm{~mL})$ was added and the aqueous solution was stirred for $30 \mathrm{~min}$ at RT. The solution was then made alkaline to $\mathrm{pH} 9$ with saturated aqueous sodium bicarbonate. The aqueous layer was extracted with EtOAc $(2 \times 30 \mathrm{~mL})$, and the combined organic layers were washed with brine $(15 \mathrm{~mL})$, passed through a hydrophobic frit and concentrated in vacuo. The crude product was purified by reverse phase prep HPLC, with $30-85 \% \mathrm{HpH} \mathrm{MeCN} / \mathrm{aq} . \mathrm{NaHCO}_{3}$ as the eluent, to afford $\mathbf{2 f}(0.91 \mathrm{~g}, 58 \%)$ as an amber oil.

LCMS (High pH, UV, ESI) $\mathrm{R}_{\mathrm{t}}=1.33 \mathrm{~min},[\mathrm{M}+\mathrm{H}]^{+} 190.2$

${ }^{1} \mathrm{H}$ NMR $\left(\mathrm{CDCl}_{3}, 400 \mathrm{MHz}\right): \delta 7.41(\mathrm{~d}, J=7.3 \mathrm{~Hz}, 2 \mathrm{H}), 7.36(\mathrm{t}, J=7.4 \mathrm{~Hz}, 2 \mathrm{H}), 7.28$ (tt, $J=7.1$, $2.5 \mathrm{~Hz}, 1 \mathrm{H}$ ), 3.70 (s, 2H), 2.69 (br. t, $J=5.2 \mathrm{~Hz}, 4 \mathrm{H}$ ), 1.69 (br. s, 8H).

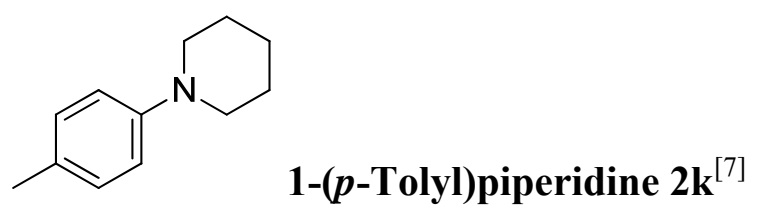

Under a nitrogen atmosphere, 4-chlorotoluene $(0.59 \mathrm{~mL}, 5.0 \mathrm{mmol})$ was added to a solution of piperidine $(0.59 \mathrm{~mL}, 6.0 \mathrm{mmol})$, 1,3-bis(2,6-diisopropylphenyl)-1H-imidazol-3-ium chloride ( $85 \mathrm{mg}, 0.2 \mathrm{mmol})$, potassium tert-butoxide $(842 \mathrm{mg}, 7.5 \mathrm{mmol})$ and $\mathrm{Pd}_{2}(\mathrm{dba})_{3}(46$ $\mathrm{mg}, 0.05 \mathrm{mmol})$ in 1,4-dioxane $(15 \mathrm{~mL})$, and the reaction mixture was stirred at $100{ }^{\circ} \mathrm{C}$ for 24 h. The reaction mixture was allowed to cool to RT, before addition of water $(20 \mathrm{~mL})$ and extraction into diethyl ether $(2 \times 30 \mathrm{~mL})$. The combined organic layers were washed with brine $(25 \mathrm{~mL})$, passed through a hydrophobic frit and concentrated in vacuo. The crude material was purified by silica gel chromatography using $0-40 \% \quad(3: 1$ EtOAc:EtOH)/cyclohexane as the eluent, affording $\mathbf{2 k}(363 \mathrm{mg}, 41 \%)$ as a yellow oil.

LCMS (High pH, UV, ESI) $\mathrm{R}_{\mathrm{t}}=1.34 \mathrm{~min},[\mathrm{M}+\mathrm{H}]^{+} 176.2$

${ }^{1} \mathrm{H} \mathrm{NMR}\left(\mathrm{CDCl}_{3}, 400 \mathrm{MHz}\right): \delta 7.07$ (d, $\left.J=8.3 \mathrm{~Hz}, 2 \mathrm{H}\right), 6.87$ (d, $\left.J=8.6 \mathrm{~Hz}, 2 \mathrm{H}\right), 3.11$ (t, $J=5.4$ $\mathrm{Hz}, 4 \mathrm{H}$ ), 2.28 (s, 3H), 1.73 (quin, $J=5.6 \mathrm{~Hz}, 4 \mathrm{H}$ ), 1.57 (quin, $J=5.8 \mathrm{~Hz}, 2 \mathrm{H}$ ). 
<smiles>C[C@H](c1ccccc1)N1CCCCC1</smiles>

\section{(R)- 1-(1-Phenylethyl)piperidine $2 \mathrm{~m}^{[8]}$}

A solution of $(R)-1$-phenylethanamine $(0.80 \mathrm{~mL}, 6.2 \mathrm{mmol})$ in $\mathrm{MeCN}(8.8 \mathrm{~mL})$ was added to a mixture of 1,5-dibromopentane $(1.05 \mathrm{~mL}, 7.4 \mathrm{mmol})$ and potassium carbonate $(3.4 \mathrm{~g}, 24.8$ $\mathrm{mmol})$ in Acetonitrile $(16.0 \mathrm{~mL})$. The reaction mixture was stirred at $50{ }^{\circ} \mathrm{C}$ for $42 \mathrm{~h}$. The reaction mixture was allowed to cool to $\mathrm{RT}$, and then filtered through a sintered funnel and the filtrate was concentrated in vacuo. The crude material was purified by silica gel chromatography, with $35-80 \%$ TBME $\quad(5 \%$ methanol, $2 \%$ triethylamine modifier)/cyclohexane to afford $\mathbf{2 m}(0.95 \mathrm{~g}, 81 \%)$ as a colorless oil.

LCMS (High pH, UV, ESI) $\mathrm{R}_{\mathrm{t}}=1.23 \mathrm{~min},[\mathrm{M}+\mathrm{H}]^{+} 190.1$

${ }^{1} \mathrm{H}$ NMR $\left(\mathrm{CDCl}_{3}, 400 \mathrm{MHz}\right): \delta 7.31(\mathrm{~d}, J=4.5 \mathrm{~Hz}, 4 \mathrm{H}), 7.21-7.26(\mathrm{~m}, 1 \mathrm{H}), 3.41(\mathrm{q}, J=6.8 \mathrm{~Hz}$, $1 \mathrm{H}), 2.31-2.46(\mathrm{~m}, 4 \mathrm{H}), 1.56$ (quin, $J=5.6 \mathrm{~Hz}, 4 \mathrm{H}), 1.41(\mathrm{t}, J=5.8 \mathrm{~Hz}, 2 \mathrm{H}), 1.38(\mathrm{~d}, J=6.8 \mathrm{~Hz}$, $3 \mathrm{H})$.<smiles>COc1ccc(CN2CCCC(C)C2)cc1</smiles>

\section{(S)-1-(4-Methoxybenzyl)-3-methylpiperidine 2n}

(S)-3-Methylpiperidine $(0.65 \mathrm{~mL}, 5.5 \mathrm{mmol})$, 4-methoxybenzyl chloride $(0.68 \mathrm{~mL}, 5.0 \mathrm{mmol})$ and potassium carbonate $(0.83 \mathrm{~g}, 6.0 \mathrm{mmol})$ were heated to $55^{\circ} \mathrm{C}$ in $\mathrm{MeCN}(20 \mathrm{~mL})$ for $42 \mathrm{~h}$. The reaction mixture was cooled to RT, and then passed through a sintered funnel and the filtrate was concentrated in vacuo. The crude material was purified by silica gel chromatography, with $25-80 \%$ TBME $\quad(5 \%$ methanol, $2 \%$ triethylamine modifier)/cyclohexane, to afford $\mathbf{2 n}(0.78 \mathrm{~g}, 71 \%)$ as a colorless oil.

LCMS (High pH, UV, ESI) $\mathrm{R}_{\mathrm{t}}=1.23 \mathrm{~min},[\mathrm{M}+\mathrm{H}]^{+} 220.2$

${ }^{1} \mathrm{H} \mathrm{NMR}\left(\mathrm{CDCl}_{3}, 400 \mathrm{MHz}\right): \delta 7.24(\mathrm{~d}, J=8.8 \mathrm{~Hz}, 2 \mathrm{H}), 6.86(\mathrm{~d}, J=8.6 \mathrm{~Hz}, 2 \mathrm{H}), 3.81(\mathrm{~s}, 3 \mathrm{H})$, 3.43 (s, 2H), 2.73-2.84 (m, 2H), 1.85 (td, $J=11.1,3.5 \mathrm{~Hz}, 1 \mathrm{H}), 1.51-1.74(\mathrm{~m}, 5 \mathrm{H}), 0.86-0.92$ (m, 1H), 0.85 (d, J=6.3 Hz, 3H)

${ }^{13} \mathrm{C} \mathrm{NMR}\left(\mathrm{CDCl}_{3}, 101 \mathrm{MHz}\right): \delta 158.6,130.7,130.3,113.5,63.0,61.9,55.2,53.9,33.1,31.1$, 25.6, 19.8

$v_{\max }\left(\mathrm{cm}^{-1}\right)$ (thin film): 2927, 1612, 1510

HRMS: Calculated for $\mathrm{C}_{14} \mathrm{H}_{22} \mathrm{NO} 220.1696$, found $[\mathrm{M}+\mathrm{H}]^{+}: 220.1689$ (-3.4 ppm). 


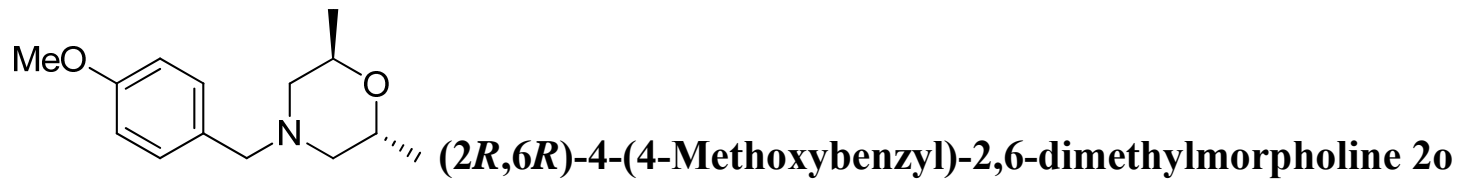

(2R,6R)-2,6-Dimethylmorpholine $(0.70 \mathrm{~mL}, 5.5 \mathrm{mmol})$, 4-methoxybenzyl chloride $(0.68 \mathrm{~mL}$, $5.0 \mathrm{mmol})$ and potassium carbonate $(0.83 \mathrm{~g}, 6.0 \mathrm{mmol})$ were heated to $50{ }^{\circ} \mathrm{C}$ in $\mathrm{MeCN}(20$ $\mathrm{mL}$ ) for $42 \mathrm{~h}$. The reaction mixture was cooled to RT, and then passed through a sintered funnel and the filtrate was concentrated in vacuo. The crude material was purified by silica gel chromatography, with 0-20\% (3:1 EtOAc:EtOH)/cyclohexane, to afford $20(1.03 \mathrm{~g}, 87 \%)$ as a colorless oil.

LCMS (High pH, UV, ESI) $\mathrm{R}_{\mathrm{t}}=1.11 \mathrm{~min},[\mathrm{M}+\mathrm{H}]^{+} 236.2$

${ }^{1} \mathrm{H}$ NMR $\left(\mathrm{CDCl}_{3}, 400 \mathrm{MHz}\right): \delta 7.25(\mathrm{~d}, J=8.6 \mathrm{~Hz}, 2 \mathrm{H}), 6.86(\mathrm{~d}, J=8.6 \mathrm{~Hz}, 2 \mathrm{H}), 4.01$ (quind, $J=6.3,3.5 \mathrm{~Hz}, 2 \mathrm{H}), 3.80$ (s, 3H), $3.42(\mathrm{~d}, J=12.6 \mathrm{~Hz}, 1 \mathrm{H}), 3.33(\mathrm{~d}, J=12.9 \mathrm{~Hz}, 1 \mathrm{H}), 2.45$ (dd, $J=11.0,3.2 \mathrm{~Hz}, 2 \mathrm{H}), 2.13(\mathrm{dd}, J=11.0,5.7 \mathrm{~Hz}, 2 \mathrm{H}), 1.24$ (d, $J=6.3 \mathrm{~Hz}, 6 \mathrm{H})$

${ }^{13} \mathrm{C} \mathrm{NMR}\left(\mathrm{CDCl}_{3}, 101 \mathrm{MHz}\right): \delta 158.7,130.4,129.9,113.6,66.7,62.5,58.6,55.2,18.2$

$v_{\max }\left(\mathrm{cm}^{-1}\right)$ (thin film): 2970, 2803, 1612, 1510

HRMS: Calculated for $\mathrm{C}_{14} \mathrm{H}_{22} \mathrm{NO}_{2} 236.1645$, found $[\mathrm{M}+\mathrm{H}]^{+}: 236.1638$ (-2.9 ppm).<smiles>CC(c1ccccc1)N1CCCCC1</smiles>

\section{1-(1-Phenylethyl)piperidine 2s}

A solution of 1-phenylethanamine $(0.80 \mathrm{~mL}, 6.2 \mathrm{mmol})$ in $\mathrm{MeCN}(8.8 \mathrm{~mL})$ was added to a mixture of 1,5-dibromopentane $(1.05 \mathrm{~mL}, 7.4 \mathrm{mmol})$ and potassium carbonate $(3.4 \mathrm{~g}, 24.8$ mmol) in Acetonitrile $(16.0 \mathrm{~mL})$. The reaction mixture was stirred at $50{ }^{\circ} \mathrm{C}$ for $42 \mathrm{~h}$. The reaction mixture was allowed to cool to $\mathrm{RT}$, and then filtered through a sintered funnel and the filtrate was concentrated in vacuo. The crude material was purified by silica gel chromatography, with $35-80 \%$ TBME $\quad(5 \%$ methanol, $2 \%$ triethylamine modifier)/cyclohexane to afford $\mathbf{2 m}(1.02 \mathrm{~g}, 87 \%)$ as a colorless oil.

LCMS (High pH, UV, ESI) $\mathrm{R}_{\mathrm{t}}=1.24 \mathrm{~min},[\mathrm{M}+\mathrm{H}]^{+} 190.2$

${ }^{1} \mathrm{H} \mathrm{NMR}\left(\mathrm{CDCl}_{3}, 400 \mathrm{MHz}\right): \delta 7.33(\mathrm{~d}, \mathrm{~J}=4.3 \mathrm{~Hz}, 4 \mathrm{H}), 7.22-7.28(\mathrm{~m}, 1 \mathrm{H}), 3.42$ (q, J=6.8 Hz, $1 \mathrm{H}), 2.31-2.48(\mathrm{~m}, 4 \mathrm{H}), 1.58$ (quin, $\mathrm{J}=6.3 \mathrm{~Hz}, 4 \mathrm{H}), 1.41-1.45(\mathrm{~m}, 2 \mathrm{H}), 1.40 \mathrm{ppm}(\mathrm{d}, \mathrm{J}=6.8 \mathrm{~Hz}$, $3 \mathrm{H})$

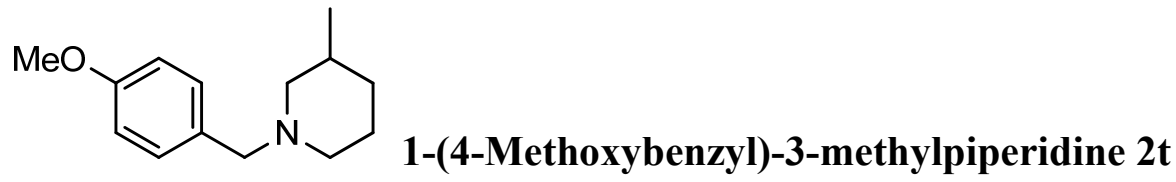

3-methylpiperidine $(0.65 \mathrm{~mL}, 5.5 \mathrm{mmol})$, 4-methoxybenzyl chloride $(0.68 \mathrm{~mL}, 5.0 \mathrm{mmol})$ and potassium carbonate $(0.83 \mathrm{~g}, 6.0 \mathrm{mmol})$ were heated to $55^{\circ} \mathrm{C}$ in $\mathrm{MeCN}(20 \mathrm{~mL})$ for $21 \mathrm{~h}$. 
The reaction mixture was cooled to RT, and then passed through a sintered funnel and the filtrate was concentrated in vacuo. The crude material was purified by silica gel chromatography, with $0-20 \%$ (3:1 EtOAc/EtOH)/cyclohexane, to afford $\mathbf{2 p}(0.87 \mathrm{~g}, 79 \%)$ as a colorless oil.

LCMS (High pH, UV, ESI) $\mathrm{R}_{\mathrm{t}}=1.25 \mathrm{~min},[\mathrm{M}+\mathrm{H}]^{+} 220.3$

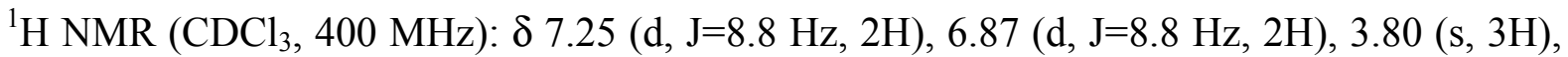
$3.44(\mathrm{~s}, 2 \mathrm{H}), 2.81(\mathrm{t}, \mathrm{J}=10.7 \mathrm{~Hz}, 2 \mathrm{H}), 1.86(\mathrm{td}, \mathrm{J}=11.0,3.8 \mathrm{~Hz}, 1 \mathrm{H}), 1.53-1.75(\mathrm{~m}, 5 \mathrm{H}), 0.88-$ $0.94(\mathrm{~m}, 1 \mathrm{H}), 0.87(\mathrm{~d}, \mathrm{~J}=6.3 \mathrm{~Hz}, 3 \mathrm{H})$

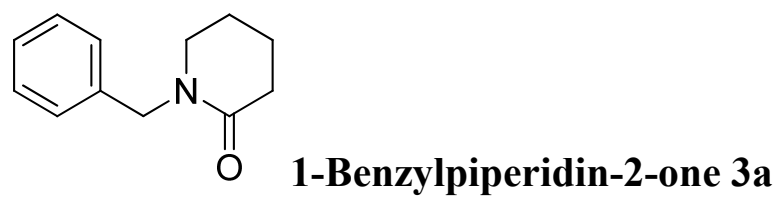

\section{Example synthetic procedure}

Iodine $(381 \mathrm{mg}, 1.50 \mathrm{mmol})$ was added to a mixture of 1-benzylpiperidine $(36.9 \mu \mathrm{L}, 0.20$

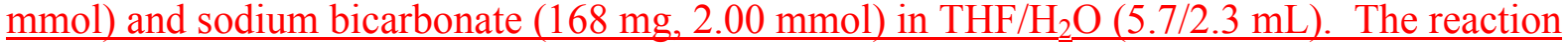
mixture was stirred gently at room temperature for $4 \mathrm{~h}$ and monitored by LCMS. The reaction mixture was then pipetted into a solution of saturated aqueous sodium thiosulfate (10 $\mathrm{mL})$ and saturated aqueous sodium bicarbonate $(10 \mathrm{~mL})$. The crude material was extracted in DCM $(2 \times 10 \mathrm{~mL})$, and the combined organic layers were washed with saturated aqueous sodium bicarbonate $(10 \mathrm{~mL})$, passed through a hydrophobic frit, concentrated in vacuo. The crude material was purified by silica gel chromatography using 35-60\% TBME (with 1\% triethylamine, $5 \%$ methanol modifier)/cyclohexane as the eluent, to afford 3a (36.3 $\mathrm{mg}, 96 \%)$ as a yellow oil.*

General procedure $A$ was followed. Iodine $(381 \mathrm{mg}, 1.50 \mathrm{mmol})$ was added to a mixture of 1 benzylpiperidine $(36.9 \mu \mathrm{L}, 0.20 \mathrm{mmol}$ ) and sodium biearbonate $(168 \mathrm{mg}, 2.00 \mathrm{mmm})$ in $\mathrm{THF} / \mathrm{H}_{2} \mathrm{O}(5.7 / 2.3 \mathrm{~mL})$. Purification was carried out by siliea gel chremategraphy using 35 $60 \%$ TBME (with 1\% triethylamine, 5\% methanol modifier)/eyclohexane as the eluent, to afford $3 \mathbf{a}(36.3 \mathrm{mg}, 96 \%)$ as a yellow oil.*

LCMS (High pH, UV, ESI) $\mathrm{R}_{\mathrm{t}}=0.85 \mathrm{~min},[\mathrm{M}+\mathrm{H}]^{+} 190.1$

${ }^{1} \mathrm{H} \mathrm{NMR}\left(\mathrm{CDCl}_{3}, 400 \mathrm{MHz}\right): \delta$ 7.23-7.36 (m, 5H), $4.61(\mathrm{~s}, 2 \mathrm{H}), 3.21(\mathrm{t}, J=5.7 \mathrm{~Hz}, 2 \mathrm{H}), 2.48$ $(\mathrm{t}, J=6.5 \mathrm{~Hz}, 2 \mathrm{H}), 1.73-1.86(\mathrm{~m}, 4 \mathrm{H})$

${ }^{13} \mathrm{C} \mathrm{NMR}\left(\mathrm{CDCl}_{3}, 101 \mathrm{MHz}\right): \delta 169.8,137.3,128.5,128.0,127.3,50.1,47.3,32.5,23.2,21.4$

$v_{\max }\left(\mathrm{cm}^{-1}\right)($ thin film): 2944, 1632

HRMS: Calculated for $\mathrm{C}_{12} \mathrm{H}_{16} \mathrm{NO} 190.1226$, found $[\mathrm{M}+\mathrm{H}]^{+}: 190.1227$ (0.5 ppm).

*3.2 wt\% iodinated lactam co-eluted with product 
<smiles>COc1ccc(CN2CCCCC2=O)cc1</smiles>

\section{1-(4-Methoxybenzyl)piperidin-2-one 3b}

General procedure A was followed. Iodine $(381 \mathrm{mg}, 1.50 \mathrm{mmol})$ was added to a mixture of 2b (41 mg, $0.20 \mathrm{mmol})$ and sodium bicarbonate $(168 \mathrm{mg}, 2.00 \mathrm{mmol})$ in $\mathrm{THF} / \mathrm{H}_{2} \mathrm{O}(5.7 / 2.3$ $\mathrm{mL}$ ). Purification was carried out by silica gel chromatography using 50-100\% TBME (with $1 \%$ triethylamine \& 5\% methanol modifier)/cyclohexane as the eluent, to afford $\mathbf{3 b}(39.8 \mathrm{mg}$, $91 \%$ ) as a colorless oil.

LCMS (High pH, UV, ESI) $\mathrm{R}_{\mathrm{t}}=0.85 \mathrm{~min},[\mathrm{M}+\mathrm{H}]^{+} 220.1$

${ }^{1} \mathrm{H} \mathrm{NMR}\left(\mathrm{CDCl}_{3}, 400 \mathrm{MHz}\right): \delta 7.19(\mathrm{~d}, J=8.6 \mathrm{~Hz}, 2 \mathrm{H}), 6.84(\mathrm{~d}, J=8.6 \mathrm{~Hz}, 2 \mathrm{H}), 4.52(\mathrm{~s}, 2 \mathrm{H})$, 3.79 (s, 3H), 3.17 (t, J=5.5 Hz, 2H), 2.44 (t, J=6.5 Hz, 2H), 1.68-1.84 (m, 4H)

${ }^{13} \mathrm{C} \mathrm{NMR}\left(\mathrm{CDCl}_{3}, 101 \mathrm{MHz}\right): \delta 169.7,158.9,129.5,129.5,113.9,55.2,49.5,47.0,32.5$, $23.2,21.4$

$v_{\max }\left(\mathrm{cm}^{-1}\right)($ thin film): 2936, 1633

HRMS: Calculated for $\mathrm{C}_{13} \mathrm{H}_{18} \mathrm{NO}_{2} 220.1332$, found $[\mathrm{M}+\mathrm{H}]^{+}: 220.1337$ (2.4 ppm).

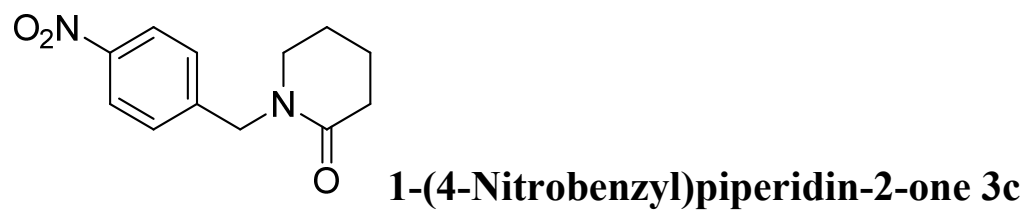

General procedure A was followed. Iodine $(432 \mathrm{mg}, 1.70 \mathrm{mmol})$ was added to a mixture of 2c (50 mg, $0.23 \mathrm{mmol})$ and sodium bicarbonate $(191 \mathrm{mg}, 2.27 \mathrm{mmol})$ in $\mathrm{THF} / \mathrm{H}_{2} \mathrm{O}(6.5 / 2.6$ $\mathrm{mL})$. Purification was carried out by silica gel chromatography using 40-60\% (3:1 EtOAc/EtOH) (with 1\% ammonia modifier)/cyclohexane as the eluent, to afford 3c (50.4 mg, $95 \%)$ as a white solid.

LCMS (High pH, UV, ESI) $\mathrm{R}_{\mathrm{t}}=0.84 \mathrm{~min},[\mathrm{M}+\mathrm{H}]^{+} 235.1$

${ }^{1} \mathrm{H} \mathrm{NMR}\left(\mathrm{CDCl}_{3}, 400 \mathrm{MHz}\right): \delta 8.19$ (d, J=8.8 Hz, 2H), 7.43 (d, J=8.6 Hz, 2H), 4.69 (s, 2H), 3.25 (t, $J=5.4 \mathrm{~Hz}, 2 \mathrm{H}), 2.51$ (t, $J=6.2 \mathrm{~Hz}, 2 \mathrm{H}), 1.79-1.88(\mathrm{~m}, 4 \mathrm{H})$

${ }^{13} \mathrm{C}$ NMR $\left(\mathrm{CDCl}_{3}, 101 \mathrm{MHz}\right): \delta 170.1,147.4,145.0,128.6,123.9,49.9,47.9,32.3,23.2,21.3$ $v_{\max }\left(\mathrm{cm}^{-1}\right)$ (thin film): 2953, 2879, 1628

HRMS: Calculated for $\mathrm{C}_{12} \mathrm{H}_{15} \mathrm{~N}_{2} \mathrm{O}_{3}$ 235.1077, found $[\mathrm{M}+\mathrm{H}]^{+}: 235.1079$ (0.6 ppm).<smiles>O=C1c2ccccc2CCN1Cc1ccccc1</smiles> 
General procedure A was followed. Iodine $(426 \mathrm{mg}, 1.68 \mathrm{mmol})$ was added to a mixture of 2d (50 mg, $0.22 \mathrm{mmol})$ and sodium bicarbonate $(188 \mathrm{mg}, 2.24 \mathrm{mmol}) \mathrm{in} \mathrm{THF} / \mathrm{H}_{2} \mathrm{O}(6.4 / 2.6$ $\mathrm{mL}$ ). Purification was carried out by silica gel chromatography using 10-30\% TBME (with $1 \% 4 \mathrm{M}$ ammonia in methanol modifier)/cyclohexane as the eluent, to afford 3d $(42.6 \mathrm{mg}$, $80 \%$ ) as a colorless oil.

LCMS (High pH, UV, ESI) $\mathrm{R}_{\mathrm{t}}=1.09 \mathrm{~min},[\mathrm{M}+\mathrm{H}]^{+} 238.1$

${ }^{1} \mathrm{H}$ NMR $\left(\mathrm{CDCl}_{3}, 400 \mathrm{MHz}\right): \delta 8.18(\mathrm{dd}, J=7.6,1.8 \mathrm{~Hz}, 1 \mathrm{H}), 7.41-7.47(\mathrm{~m}, 1 \mathrm{H}), 7.32-7.40$ (m, 5H), 7.27-7.32 (m, 1H), $7.18(\mathrm{~d}, J=7.3 \mathrm{~Hz}, 1 \mathrm{H}), 4.82(\mathrm{~s}, 2 \mathrm{H}), 3.51$ (t, $J=6.7 \mathrm{~Hz}, 2 \mathrm{H}), 2.96$ $(\mathrm{t}, J=6.7 \mathrm{~Hz}, 2 \mathrm{H})$

${ }^{13} \mathrm{C} \mathrm{NMR}\left(\mathrm{CDCl}_{3}, 126 \mathrm{MHz}\right): \delta 164.6,138.1,137.5,131.7,129.4,128.7,128.5,128.1,127.5$, $127.1,126.9,50.5,45.4,28.1$

$v_{\max }\left(\mathrm{cm}^{-1}\right)$ (thin film): 3030, 2935, 1644

HRMS: Calculated for $\mathrm{C}_{16} \mathrm{H}_{16} \mathrm{NO} 238.1226$, found $[\mathrm{M}+\mathrm{H}]^{+}: 238.1226$ (0.0 ppm).

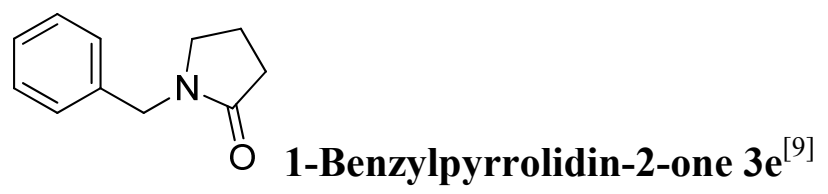

General procedure A was followed. Iodine $(295 \mathrm{mg}, 1.16 \mathrm{mmol})$ was added to a mixture of 1-benzylpyrrolidine $(25 \mathrm{mg}, 0.16 \mathrm{mmol})$ and sodium bicarbonate $(130 \mathrm{mg}, 1.55 \mathrm{mmol})$ in $\mathrm{THF} / \mathrm{H}_{2} \mathrm{O}(4.4 / 1.8 \mathrm{~mL})$. Purification was carried out by silica gel chromatography using 30$85 \%$ TBME (with 1\% 4M ammonia in methanol modifier)/cyclohexane as the eluent, to afford 3 e $(18.7 \mathrm{mg}, 69 \%)$ as an orange oil.*

LCMS (High pH, UV, ESI) $\mathrm{R}_{\mathrm{t}}=0.79 \mathrm{~min},[\mathrm{M}+\mathrm{H}]^{+} 176.1$

${ }^{1} \mathrm{H} \mathrm{NMR}\left(\mathrm{CDCl}_{3}, 400 \mathrm{MHz}\right): \delta$ 7.22-7.37 (m, 5H), 4.46 (s, 2H), 3.27 (t, J=7.1 Hz, 2H), 2.45 (t, $J=8.1 \mathrm{~Hz}, 2 \mathrm{H}$ ), 2.00 (quin, $J=7.6 \mathrm{~Hz}, 2 \mathrm{H}$ )

${ }^{13} \mathrm{C} \mathrm{NMR}\left(\mathrm{CDCl}_{3}, 101 \mathrm{MHz}\right): \delta 174.9,136.6,128.6,128.1,127.5,46.6,30.9,17.7$

$v_{\max }\left(\mathrm{cm}^{-1}\right)($ thin film): 2918,1675

HRMS: Calculated for $\mathrm{C}_{11} \mathrm{H}_{14} \mathrm{NO} 176.1070$, found $[\mathrm{M}+\mathrm{H}]^{+}: 176.1069$ (-0.5 ppm).

*LCMS shows $9 \%$ area of an unknown artifact at $0.66 \mathrm{~min}$, but no impurity was observed by $N M R$, so the peak was attributed to some small amount of a highly UV active impurity.<smiles>O=C1CCCCCN1Cc1ccccc1</smiles>

1-Benzylazepan-2-one 3f 
General procedure A was followed. Iodine $(503 \mathrm{mg}, 1.98 \mathrm{mmol})$ was added to a mixture of 2f $(50 \mathrm{mg}, 0.26 \mathrm{mmol})$ and sodium bicarbonate $(222 \mathrm{mg}, 2.64 \mathrm{mmol}) \mathrm{in} \mathrm{THF} / \mathrm{H}_{2} \mathrm{O}(7.6 / 3.0$ $\mathrm{mL}$ ). Purification was carried out by silica gel chromatography using 30-65\% TBME (with $1 \% 4 \mathrm{M}$ ammonia in methanol modifier)/cyclohexane as the eluent, to afford $\mathbf{3 f}(35.5 \mathrm{mg}$, $66 \%$ ) as a brown oil.

LCMS (High pH, UV, ESI) $\mathrm{R}_{\mathrm{t}}=0.95 \mathrm{~min},[\mathrm{M}+\mathrm{H}]^{+} 204.1$

${ }^{1} \mathrm{H}$ NMR $\left(\mathrm{CDCl}_{3}, 400 \mathrm{MHz}\right): \delta$ 7.22-7.35 (m, 5H), 4.59 (s, 2H), 3.24-3.35 (m, 2H), 2.57-2.64 (m, 2H), 1.64-1.75 (m, 4H), 1.45-1.54 (m, 2H)

${ }^{13} \mathrm{C} \mathrm{NMR}\left(\mathrm{CDCl}_{3}, 101 \mathrm{MHz}\right): \delta 176.0,137.9,128.5,128.1,127.3,51.1,48.9,37.2,29.9$, $28.1,23.4$

$v_{\max }\left(\mathrm{cm}^{-1}\right)$ (thin film): 2928, 2856, 1635

HRMS: Calculated for $\mathrm{C}_{13} \mathrm{H}_{18} \mathrm{NO} 204.1383$, found $[\mathrm{M}+\mathrm{H}]^{+}: 204.1379$ (-1.9 ppm).<smiles>O=C1COCCN1Cc1ccccc1</smiles>

\section{4-Benzylmorpholin-3-one 3g}

General procedure B was followed. Iodine $(537 \mathrm{mg}, 2.12 \mathrm{mmol})$ was added to a mixture of 4-benzylmorpholine $(48.4 \mu \mathrm{L}, 0.28 \mathrm{mmol})$ and sodium bicarbonate $(237 \mathrm{mg}, 2.82 \mathrm{mmol})$ in $\mathrm{DMSO} / \mathrm{H}_{2} \mathrm{O}(8.1 / 3.2 \mathrm{~mL})$. Purification was carried out by silica gel chromatography using $30-80 \%$ TBME (with 2\% triethylamine \& $5 \%$ methanol modifier)/cyclohexane as the eluent, to afford $\mathbf{3 g}(42.0 \mathrm{mg}, 78 \%)$ as a colorless oil.*

LCMS (High pH, UV, ESI) $\mathrm{R}_{\mathrm{t}}=0.71 \mathrm{~min},[\mathrm{M}+\mathrm{H}]^{+} 192.0$

${ }^{1} \mathrm{H} \mathrm{NMR}\left(\mathrm{CDCl}_{3}, 400 \mathrm{MHz}\right): \delta$ 7.26-7.38 (m, 5H), $4.64(\mathrm{~s}, 2 \mathrm{H}), 4.26(\mathrm{~s}, 2 \mathrm{H}), 3.85(\mathrm{t}, J=5.3$ $\mathrm{Hz}, 2 \mathrm{H}), 3.28(\mathrm{t}, J=5.0 \mathrm{~Hz}, 2 \mathrm{H})$

${ }^{13} \mathrm{C} \mathrm{NMR}\left(\mathrm{CDCl}_{3}, 101 \mathrm{MHz}\right): \delta 166.8,136.1,128.7,128.3,127.7,68.2,63.9,49.5,45.5$

$v_{\max }\left(\mathrm{cm}^{-1}\right)$ (thin film): 2924, 2866, 1646

HRMS: Calculated for $\mathrm{C}_{11} \mathrm{H}_{14} \mathrm{NO}_{2}$ 192.1019, found $[\mathrm{M}+\mathrm{H}]^{+}: 192.1019$ (-0.2 ppm).

*LCMS shows $8 \%$ area of an unknown artifact at 0.65 min, but no impurity was observed by $N M R$, so the peak was attributed to some small amount of a highly UV active impurity.<smiles>CC(C)(C)OC(=O)N1CCN(Cc2ccccc2)C(=O)C1</smiles>

\section{t-Butyl 4-benzyl-3-oxopiperazine-1-carboxylate $3 \mathrm{~h}$}

General procedure A was followed. Iodine $(381 \mathrm{mg}, 1.50 \mathrm{mmol})$ was added to a mixture of $t$ butyl-4-benzylpiperazine-1-carboxylate $(55 \mathrm{mg}, 0.20 \mathrm{mmol})$ and sodium bicarbonate (168 
$\mathrm{mg}, 2.00 \mathrm{mmol})$ in $\mathrm{THF} / \mathrm{H}_{2} \mathrm{O}(5.7 / 2.3 \mathrm{~mL}) .{ }^{1} \mathrm{H}$ NMR analysis of the crude material showed $56 \%$ conversion to $3 \mathrm{~h}$ based on the peak at $4.62 \mathrm{ppm}$, and $41 \%$ remaining starting material. Purification was carried out by silica gel chromatography using 0-35\% TBME (with 1\% triethylamine \& 5\% methanol modifier)/cyclohexane as the eluent, to afford $\mathbf{3 h}(25.6 \mathrm{mg}$, $44 \%$ ) as a white solid.

LCMS (High pH, UV, ESI) $\mathrm{R}_{\mathrm{t}}=1.04 \mathrm{~min},[\mathrm{M}+\mathrm{H}]^{+} 291.1$

${ }^{1} \mathrm{H}$ NMR $\left(\mathrm{CDCl}_{3}, 400 \mathrm{MHz}\right): \delta$ 7.24-7.38 (m, 5H), $4.63(\mathrm{~s}, 2 \mathrm{H}), 4.17$ (s, 2H), 3.59 (t, J=5.4 $\mathrm{Hz}, 2 \mathrm{H}), 3.23-3.29(\mathrm{~m}, 2 \mathrm{H}), 1.46(\mathrm{~s}, 9 \mathrm{H})$

${ }^{13} \mathrm{C} \mathrm{NMR}\left(\mathrm{CDCl}_{3}, 101 \mathrm{MHz}\right): \delta 165.7,153.8,136.2,128.8,128.2,127.8,80.8,50.0,48.0$, $45.6,40.0,28.3$

$v_{\max }\left(\mathrm{cm}^{-1}\right)$ (thin film): 2979, 2928, 1684, 1637

HRMS: Calculated for $\mathrm{C}_{16} \mathrm{H}_{23} \mathrm{~N}_{2} \mathrm{O}_{3}$ 291.1703, found [M+H] $]^{+}: 291.1709$ (2.1 ppm).

4-Benzyl-1-methylpiperazin-2-one 3i

General procedure A was followed. Iodine $(381 \mathrm{mg}, 1.50 \mathrm{mmol})$ was added to a mixture of 1-benzyl-4-methylpiperazine $(38 \mathrm{mg}, 0.20 \mathrm{mmol})$ and sodium bicarbonate $(168 \mathrm{mg}, 2.00$ $\mathrm{mmol})$ in $\mathrm{THF} / \mathrm{H}_{2} \mathrm{O}(5.7 / 2.3 \mathrm{~mL}) .{ }^{1} \mathrm{H} \mathrm{NMR}$ analysis of the crude material showed $45 \%$ conversion to $3 \mathbf{i}$ based on the peak at $3.54 \mathrm{ppm}$, and 29\% remaining starting material against 3,4,5-trichloropyridine $(0.12 \mathrm{mmol})$ as a standard. Purification was carried out by silica gel chromatography using 30-100\% TBME (with 1\% triethylamine \& 5\% methanol modifier)/cyclohexane as the eluent, to afford $3 \mathbf{i}(13.8 \mathrm{mg}, 34 \%)$ as a colorless oil.*

LCMS (High pH, UV, ESI) $\mathrm{R}_{\mathrm{t}}=0.73 \mathrm{~min},[\mathrm{M}+\mathrm{H}]^{+} 205.2$

${ }^{1} \mathrm{H} \mathrm{NMR}\left(\mathrm{CDCl}_{3}, 400 \mathrm{MHz}\right): \delta$ 7.24-7.36 (m, 5H), $3.55(\mathrm{~s}, 2 \mathrm{H}), 3.30(\mathrm{t}, J=5.3 \mathrm{~Hz}, 2 \mathrm{H}), 3.16$ (s, 2H), $2.95(\mathrm{~s}, 3 \mathrm{H}), 2.67(\mathrm{t}, J=5.6 \mathrm{~Hz}, 2 \mathrm{H})$

${ }^{13} \mathrm{C} \mathrm{NMR}\left(\mathrm{CDCl}_{3}, 101 \mathrm{MHz}\right): \delta 167.1,136.9,129.0,128.4,127.5,61.9,57.4,49.2,48.7,33.8$

$v_{\max }\left(\mathrm{cm}^{-1}\right)$ (thin film): 2924, 2807, 1645

HRMS: Calculated for $\mathrm{C}_{12} \mathrm{H}_{17} \mathrm{~N}_{2} \mathrm{O} 205.1335$, found $[\mathrm{M}+\mathrm{H}]^{+}: 205.1326$ (-4.7 ppm).

*LCMS shows $11 \%$ area of an unknown artifact at 0.64 min, but no impurity was observed by NMR, so the peak was attributed to some small amount of a highly UV active impurity.<smiles>O=C1CCCCN1c1ccc(I)cc1</smiles> 
General procedure A was followed. Iodine $(381 \mathrm{mg}, 1.50 \mathrm{mmol})$ was added to a mixture of 1-phenylpiperidine $(32.0 \mu \mathrm{L}, 0.20 \mathrm{mmol})$ and sodium bicarbonate $(168 \mathrm{mg}, 2.00 \mathrm{mmol})$ in $\mathrm{THF} / \mathrm{H}_{2} \mathrm{O}(5.7 / 2.3 \mathrm{~mL})$. Purification was carried out by silica gel chromatography using 40$85 \%$ TBME (with $1 \%$ triethylamine \& $5 \%$ methanol modifier)/cyclohexane as the eluent, to afford $\mathbf{3 j}$ (32.3 $\mathrm{mg}, 54 \%$ ) as white crystals.

LCMS (High pH, UV, ESI) $\mathrm{R}_{\mathrm{t}}=0.97 \mathrm{~min},[\mathrm{M}+\mathrm{H}]^{+} 302.0$

${ }^{1} \mathrm{H} \mathrm{NMR}\left(\mathrm{CDCl}_{3}, 400 \mathrm{MHz}\right): \delta 7.70(\mathrm{~d}, J=8.6 \mathrm{~Hz}, 2 \mathrm{H}), 7.03$ (d, $\left.J=8.6 \mathrm{~Hz}, 2 \mathrm{H}\right), 3.62$ (t, $J=5.9$ $\mathrm{Hz}, 2 \mathrm{H}), 2.55$ (t, $J=6.0 \mathrm{~Hz}, 2 \mathrm{H}), 1.88-2.00(\mathrm{~m}, 4 \mathrm{H})$

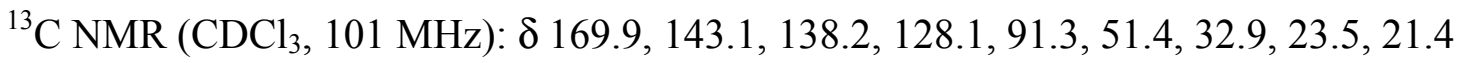

$v_{\max }\left(\mathrm{cm}^{-1}\right)$ (thin film): 2940, 2863, 1630

HRMS: Calculated for $\mathrm{C}_{11} \mathrm{H}_{13} \mathrm{INO} 302.0036$, found $[\mathrm{M}+\mathrm{H}]^{+}: 302.0032$ (-1.4 ppm).

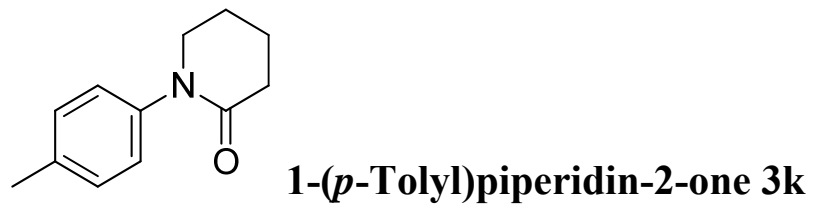

General procedure A was followed, except with the amendment that iodine was added to the reaction mixture in three portions of 2.5 equivalents after 0,1 and $2 \mathrm{~h}$. Iodine $(381 \mathrm{mg}, 1.50$ $\mathrm{mmol})$ was added in three portions to a mixture of 1-p-tolylpiperidine (35 $\mathrm{mg}, 0.20 \mathrm{mmol})$ and sodium bicarbonate $(168 \mathrm{mg}, 2.00 \mathrm{mmol})$ in $\mathrm{THF} / \mathrm{H}_{2} \mathrm{O}(5.7 / 2.3 \mathrm{~mL})$. Purification was carried out by silica gel chromatography using 35-80\% TBME (with $1 \%$ triethylamine, 5\% methanol modifier)/cyclohexane as the eluent, to afford 3k (21.2 mg, 56\%) as a white solid.

LCMS (High pH, UV, ESI) $\mathrm{R}_{\mathrm{t}}=0.85 \mathrm{~min},[\mathrm{M}+\mathrm{H}]^{+} 190.1$

${ }^{1} \mathrm{H} \mathrm{NMR}\left(\mathrm{CDCl}_{3}, 400 \mathrm{MHz}\right): \delta 7.20(\mathrm{~d}, J=8.3 \mathrm{~Hz}, 2 \mathrm{H}), 7.13$ (d, J=8.3 Hz, 2H), 3.59-3.65 (m, $2 \mathrm{H}), 2.56(\mathrm{t}, J=5.6 \mathrm{~Hz}, 2 \mathrm{H}), 2.35(\mathrm{~s}, 3 \mathrm{H}), 1.90-1.99(\mathrm{~m}, 4 \mathrm{H})$

${ }^{13} \mathrm{C} \mathrm{NMR}\left(\mathrm{CDCl}_{3}, 101 \mathrm{MHz}\right): \delta 170.0,140.9,136.5,129.8,126.0,51.8,32.9,23.6,21.5,21.0$

$v_{\max }\left(\mathrm{cm}^{-1}\right)$ (thin film): 2954, 2856, 1636

HRMS: Calculated for $\mathrm{C}_{12} \mathrm{H}_{16} \mathrm{NO} 190.1226$, found $[\mathrm{M}+\mathrm{H}]^{+}: 190.1229$ (1.4 ppm).<smiles>O=C1CC(c2ccccc2)CCN1</smiles>

\section{4-Phenylpiperidin-2-one 31}

General procedure $\mathrm{C}$ was followed. Iodine $(590 \mathrm{mg}, 2.33 \mathrm{mmol})$ was added to a mixture of 4-phenylpiperidine $(50 \mathrm{mg}, 0.31 \mathrm{mmol})$ and sodium bicarbonate $(260 \mathrm{mg}, 3.10 \mathrm{mmol})$ in $\mathrm{THF} / \mathrm{H}_{2} \mathrm{O}(8.9 / 3.5 \mathrm{~mL}) .{ }^{1} \mathrm{H} \mathrm{NMR}$ analysis of the crude material showed $51 \%$ conversion to 31 based on the peak at $3.40 \mathrm{ppm}$, and $45 \%$ remaining starting material against 3,4,5- 
trichloropyridine $(0.07 \mathrm{mmol})$ as a standard. Purification was carried out by reverse phase chromatography with $0-60 \%$ Acetonitrile $/ 10 \mathrm{mM}$ aqueous ammonium bicarbonate as the eluent, to afford 31 (23.6 mg, 43\%) as a white solid.*

LCMS (High pH, UV, ESI) $\mathrm{R}_{\mathrm{t}}=0.75 \mathrm{~min},[\mathrm{M}+\mathrm{H}]^{+} 176.1$

${ }^{1} \mathrm{H} \mathrm{NMR}\left(\mathrm{CDCl}_{3}, 400 \mathrm{MHz}\right): \delta 7.36(\mathrm{t}, J=7.6 \mathrm{~Hz}, 2 \mathrm{H}), 7.20-7.31(\mathrm{~m}, 3 \mathrm{H}), 6.64$ (br. s., $\left.1 \mathrm{H}\right)$, 3.37-3.47 (m, 2H), 3.12 (tdd, $J=11.1,5.4,2.9 \mathrm{~Hz}, 1 \mathrm{H}), 2.71$ (ddd, $J=17.6,5.4,2.0 \mathrm{~Hz}, 1 \mathrm{H}$ ), $2.51(\mathrm{dd}, J=17.9,11.2 \mathrm{~Hz}, 1 \mathrm{H}), 2.06-2.15(\mathrm{~m}, 1 \mathrm{H}), 1.89-2.02(\mathrm{~m}, 1 \mathrm{H})$

${ }^{13} \mathrm{C} \mathrm{NMR}\left(\mathrm{CDCl}_{3}, 101 \mathrm{MHz}\right): \delta 172.1,143.5,128.8,126.8,126.6,41.4,38.7,38.4,29.6$

$v_{\max }\left(\mathrm{cm}^{-1}\right)$ (thin film): 3286, 3193, 3029, 2872, 1651

HRMS: Calculated for $\mathrm{C}_{11} \mathrm{H}_{14} \mathrm{NO}$ 176.1070, found $[\mathrm{M}+\mathrm{H}]^{+}: 176.1074$ (2.5 ppm).

*LCMS shows 6\% area of an unknown artifact at $0.64 \mathrm{~min}$, but no impurity was observed by $N M R$, so the peak was attributed to some small amount of a highly UV active impurity.<smiles>C[C@H](c1ccccc1)N1CCCCC1=O</smiles>

\section{(R)-1-(1-Phenylethyl)piperidin-2-one 3m}

General procedure A was followed. Iodine $(381 \mathrm{mg}, 1.50 \mathrm{mmol})$ was added to a mixture of $2 \mathrm{~m}(38 \mathrm{mg}, 0.20 \mathrm{mmol})$ and sodium bicarbonate $(168 \mathrm{mg}, 2.00 \mathrm{mmol}) \mathrm{in} \mathrm{THF} / \mathrm{H}_{2} \mathrm{O}(5.7 / 2.3$ $\mathrm{mL}$ ). Purification was carried out by silica gel chromatography using 0-20\% TBME (with $1 \%$ triethylamine \& 5\% methanol modifier)/cyclohexane as the eluent, to afford $\mathbf{3 m}(21.6$ $\mathrm{mg}, 53 \%$ ) as an amber oil.*

LCMS (High pH, UV, ESI) $\mathrm{R}_{\mathrm{t}}=0.93 \mathrm{~min},[\mathrm{M}+\mathrm{H}]^{+} 204.2$

${ }^{1} \mathrm{H}$ NMR $\left(\mathrm{CDCl}_{3}, 400 \mathrm{MHz}\right): \delta 7.22-7.40(\mathrm{~m}, 5 \mathrm{H}), 6.16(\mathrm{q}, J=7.1 \mathrm{~Hz}, 1 \mathrm{H}), 3.11$ (ddd, $J=12.3$, 7.9, $4.6 \mathrm{~Hz}, 1 \mathrm{H}), 2.76-2.83(\mathrm{~m}, 1 \mathrm{H}), 2.49$ (t, $J=6.7 \mathrm{~Hz}, 2 \mathrm{H}), 1.70-1.81(\mathrm{~m}, 3 \mathrm{H}), 1.57-1.68(\mathrm{~m}$, $1 \mathrm{H}), 1.51(\mathrm{~d}, J=7.3 \mathrm{~Hz}, 3 \mathrm{H})$

${ }^{13} \mathrm{C} \mathrm{NMR}\left(\mathrm{CDCl}_{3}, 101 \mathrm{MHz}\right): \delta 169.6,140.5,128.4,127.3,127.2,49.7,41.4,32.5,23.2$, $21.2,15.3$

$v_{\max }\left(\mathrm{cm}^{-1}\right)$ (thin film): 2940, 2867, 1616

HRMS: Calculated for $\mathrm{C}_{13} \mathrm{H}_{18} \mathrm{NO} 204.1383$, found $[\mathrm{M}+\mathrm{H}]^{+}: 204.1382$ (-0.3 ppm)

Chiral HPLC (25 cm Chiralpak AS, 40\% EtOH/n-heptane, $1.0 \mathrm{~mL} / \mathrm{min}$, detection at $215 \mathrm{~nm}$ ) $\mathrm{R}_{\mathrm{t}}=3.9 \mathrm{~min}$ (major) and $8.0 \mathrm{~min}$ (minor), ee $=98.8 \%$.

*LCMS shows 7\% area of an unknown artifact at 1.09 min, but no impurity was observed by $N M R$, so the peak was attributed to some small amount of a highly UV active impurity. 
(S)-1-(4-Methoxybenzyl)-5-methylpiperidin-2-one $3 n^{\alpha}$ and (S)-1-(4-methoxybenzyl)-3methylpiperidin-2-one $3 n^{\beta}$

General procedure A was followed. Iodine $(381 \mathrm{mg}, 1.50 \mathrm{mmol})$ was added to a mixture of 2n (44 mg, $0.20 \mathrm{mmol})$ and sodium bicarbonate $(168 \mathrm{mg}, 2.00 \mathrm{mmol}) \mathrm{in} \mathrm{THF} / \mathrm{H}_{2} \mathrm{O}(5.7 / 2.3$ $\mathrm{mL}$ ). Purification was carried out by silica gel chromatography using 0-50\% TBME (with $1 \%$ triethylamine \& 5\% methanol modifier)/cyclohexane as the eluent, with $15 \mathrm{~min}$ isochratically at 40\% TBME (with $1 \%$ triethylamine \& 5\% methanol modifier)/cyclohexane to afford $\mathbf{3} \mathbf{n}^{\boldsymbol{\alpha}}(24.9 \mathrm{mg}, 53 \%)$ as a colorless oil, and $\mathbf{3} \mathbf{n}^{\boldsymbol{\beta}}(9.5 \mathrm{mg}, 20 \%)$ as a colorless oil.<smiles>COc1ccc(CN2CC(C)CCC2=O)cc1</smiles>

(S)-1-(4-Methoxybenzyl)-5-methylpiperidin-2-one $3 n^{\alpha}$

LCMS (High pH, UV, ESI) $\mathrm{R}_{\mathrm{t}}=0.95$ min, $[\mathrm{M}+\mathrm{H}]^{+} 234.2$

${ }^{1} \mathrm{H}$ NMR $\left(\mathrm{CDCl}_{3}, 400 \mathrm{MHz}\right): \delta 7.19(\mathrm{~d}, J=8.6 \mathrm{~Hz}, 2 \mathrm{H}), 6.85(\mathrm{~d}, J=8.6 \mathrm{~Hz}, 2 \mathrm{H}), 4.59$ (d, $J=14.9 \mathrm{~Hz}, 1 \mathrm{H}), 4.44$ (d, $J=14.1 \mathrm{~Hz}, 1 \mathrm{H}), 3.79$ (s, 3H), 3.15 (ddd, $J=11.9,5.1,1.8 \mathrm{~Hz}, 1 \mathrm{H}$ ), 2.80 (dd, $J=11.6,10.4 \mathrm{~Hz}, 1 \mathrm{H}), 2.52$ (ddd, $J=17.7,6.1,3.3 \mathrm{~Hz}, 1 \mathrm{H}), 2.36-2.47$ (m, $1 \mathrm{H}), 1.87-$ $1.96(\mathrm{~m}, 1 \mathrm{H}), 1.78-1.86(\mathrm{~m}, 1 \mathrm{H}), 1.45$ (dtd, $J=13.1,11.3,5.9 \mathrm{~Hz}, 1 \mathrm{H}), 0.94$ (d, $J=6.6 \mathrm{~Hz}, 3 \mathrm{H})$

${ }^{13} \mathrm{C} \mathrm{NMR}\left(\mathrm{CDCl}_{3}, 101 \mathrm{MHz}\right): \delta 169.6,158.9,129.4,119.6,113.9,55.2,53.9,49.5,31.7$, $29.5,29.0,18.5$

$v_{\max }\left(\mathrm{cm}^{-1}\right)$ (thin film): 2928, 2837, 1634

HRMS: Calculated for $\mathrm{C}_{14} \mathrm{H}_{20} \mathrm{NO}_{2} 234.1489$, found $[\mathrm{M}+\mathrm{H}]^{+}: 234.1492$ (1.6 ppm)

Chiral HPLC (25 cm Whelk-o 1, 10\% EtOH/n-heptane, $1.0 \mathrm{~mL} / \mathrm{min}$, detection at $215 \mathrm{~nm}$ ) $\mathrm{R}_{\mathrm{t}}$ $=39.6 \mathrm{~min}, e e=100.0 \%$.<smiles>COc1ccc(CN2CCC[C@H](C)C2=O)cc1</smiles>

(S)-1-(4-Methoxybenzyl)-3-methylpiperidin-2-one $3 n^{\beta}$

LCMS (High pH, UV, ESI) $\mathrm{R}_{\mathrm{t}}=0.97 \mathrm{~min},[\mathrm{M}+\mathrm{H}]^{+} 234.2$

${ }^{1} \mathrm{H}$ NMR $\left(\mathrm{CDCl}_{3}, 400 \mathrm{MHz}\right): \delta 7.19(\mathrm{~d}, J=8.6 \mathrm{~Hz}, 2 \mathrm{H}), 6.85(\mathrm{~d}, J=8.6 \mathrm{~Hz}, 2 \mathrm{H}), 4.60(\mathrm{~d}$, $J=14.4 \mathrm{~Hz}, 1 \mathrm{H}), 4.44(\mathrm{~d}, J=14.4 \mathrm{~Hz}, 1 \mathrm{H}), 3.80$ (s, 3H), 3.19 (dd, $J=7.3,5.1 \mathrm{~Hz}, 2 \mathrm{H}), 2.41$ $2.52(\mathrm{~m}, 1 \mathrm{H}), 1.91-2.00(\mathrm{~m}, 1 \mathrm{H}), 1.78-1.89(\mathrm{~m}, 1 \mathrm{H}), 1.65-1.78(\mathrm{~m}, 1 \mathrm{H}), 1.52$ (dtd, $J=12.9$, 9.9, 3.3 Hz, 1H), $1.29(\mathrm{~d}, J=7.1 \mathrm{~Hz}, 3 \mathrm{H})$

${ }^{13} \mathrm{C} \mathrm{NMR}\left(\mathrm{CDCl}_{3}, 101 \mathrm{MHz}\right): \delta 173.2,158.9,129.7,129.4,113.9,55.3,49.6,47.4,36.7$, $29.6,21.7,18.1$

$v_{\max }\left(\mathrm{cm}^{-1}\right)$ (thin film): 2931, 2867, 1631 
HRMS: Calculated for $\mathrm{C}_{14} \mathrm{H}_{20} \mathrm{NO}_{2}$ 234.1489, found [M+H] $]^{+}: 234.1495$ (2.6 ppm)

Chiral HPLC (25 cm Chiralpak AS-H, 25\% EtOH $/ n$-heptane, $1.0 \mathrm{~mL} / \mathrm{min}$, detection at 215 $\mathrm{nm}) \mathrm{R}_{\mathrm{t}}=5.3 \mathrm{~min}$ (minor) and 6.4 min (major), $e e=99.2 \%$.<smiles>COc1ccc(CN2CC(C)O[C@@H](C)C2=O)cc1</smiles>

(2R,6R)-4-(4-Methoxybenzyl)-2,6-dimethylmorpholin-3-one 3o

General procedure B was followed. Iodine $(381 \mathrm{mg}, 1.50 \mathrm{mmol})$ was added to a mixture of 20 (47 mg, $0.20 \mathrm{mmol})$ and sodium bicarbonate $(168 \mathrm{mg}, 2.00 \mathrm{mmol})$ in $\mathrm{THF} / \mathrm{H}_{2} \mathrm{O}(5.7 / 2.3$ $\mathrm{mL})$. Purification was carried out by silica gel chromatography using $0-30 \% \quad(3: 1$ $\mathrm{EtOAc} / \mathrm{EtOH}) / \mathrm{cyclohexane}$ as the eluent, to afford $\mathbf{3 0}(37.5 \mathrm{mg}, 75 \%)$ as a colorless oil.

LCMS (High pH, UV, ESI) $\mathrm{R}_{\mathrm{t}}=0.87 \mathrm{~min},[\mathrm{M}+\mathrm{H}]^{+} 250.2$

${ }^{1} \mathrm{H}$ NMR $\left(\mathrm{CDCl}_{3}, 400 \mathrm{MHz}\right): \delta 7.19(\mathrm{~d}, J=8.8 \mathrm{~Hz}, 2 \mathrm{H}), 6.87(\mathrm{~d}, J=8.6 \mathrm{~Hz}, 2 \mathrm{H}), 4.61(\mathrm{~d}$, $J=14.4 \mathrm{~Hz}, 1 \mathrm{H}), 4.44$ (d, $J=14.2 \mathrm{~Hz}, 1 \mathrm{H}), 4.44$ (q, $J=6.9 \mathrm{~Hz}, 1 \mathrm{H}), 4.05$ (sxt, $J=6.3 \mathrm{~Hz}, 1 \mathrm{H}$ ), $3.81(\mathrm{~s}, 3 \mathrm{H}), 3.05-3.11(\mathrm{~m}, 2 \mathrm{H}), 1.52(\mathrm{~d}, J=7.1 \mathrm{~Hz}, 3 \mathrm{H}), 1.18(\mathrm{~d}, J=6.4 \mathrm{~Hz}, 3 \mathrm{H})$

${ }^{13} \mathrm{C} \mathrm{NMR}\left(\mathrm{CDCl}_{3}, 151 \mathrm{MHz}\right): \delta 169.8,159.2,129.6,128.5,114.1,71.9,63.7,55.3,51.9$, $49.1,18.2,17.7$

$v_{\max }\left(\mathrm{cm}^{-1}\right)$ (thin film): 2977, 2934, 1645

HRMS: Calculated for $\mathrm{C}_{14} \mathrm{H}_{20} \mathrm{NO}_{3} 250.1438$, found $[\mathrm{M}+\mathrm{H}]^{+}: 250.1429$ (-3.6 ppm).<smiles>CCOC(=O)C1CCC(=O)N1Cc1ccccc1</smiles>

(S)-Ethyl 1-benzyl-5-oxopyrrolidine-2-carboxylate $3 \mathbf{p}^{[10]}$

General procedure A was followed. Iodine $(381 \mathrm{mg}, 1.50 \mathrm{mmol})$ was added to a mixture of $N$-benzyl-L-proline ethyl ester $(44.5 \mu \mathrm{L}, 0.20 \mathrm{mmol})$ and sodium bicarbonate $(168 \mathrm{mg}, 2.00$ $\mathrm{mmol})$ in $\mathrm{THF} / \mathrm{H}_{2} \mathrm{O}(5.7 / 2.3 \mathrm{~mL})$. Purification was carried out by silica gel chromatography using $0-50 \%$ (3:1 EtOAc/EtOH) (with 1\% triethylamine modifier)/cyclohexane as the eluent, to afford 3p (42.4 mg, 86\%) as a colorless oil.

LCMS (Low pH, UV, ESI) $\mathrm{R}_{\mathrm{t}}=0.92 \mathrm{~min},[\mathrm{M}+\mathrm{H}]^{+} 248.2$

${ }^{1} \mathrm{H}$ NMR $\left(\mathrm{CDCl}_{3}, 400 \mathrm{MHz}\right): \delta$ 7.25-7.34 (m, 3H), 7.19-7.23 (m, 2H), $5.02(\mathrm{~d}, J=14.7 \mathrm{~Hz}$, $1 \mathrm{H}), 4.06-4.19$ (m, 2H), 4.00 (d, $J=14.9 \mathrm{~Hz}, 1 \mathrm{H}), 3.96$ (dd, $J=9.0,3.2 \mathrm{~Hz}, 1 \mathrm{H}), 2.51-2.62$ (m, $1 \mathrm{H}$ ), 2.41 (ddd, $J=16.9,9.5,3.9 \mathrm{~Hz}, 1 \mathrm{H}), 2.18-2.30$ (m, 1H), 2.07 (ddt, $J=13.1,9.6,3.5 \mathrm{~Hz}$, $1 \mathrm{H}), 1.24$ (t, $J=7.2 \mathrm{~Hz}, 3 \mathrm{H})$ 
${ }^{13} \mathrm{C} \mathrm{NMR}\left(\mathrm{CDCl}_{3}, 101 \mathrm{MHz}\right): \delta 175.0,171.7,135.9,128.7,128.5,127.8,61.4,58.9,45.6$, $29.6,22.8,14.1$

$v_{\max }\left(\mathrm{cm}^{-1}\right)$ (thin film): 2983, 1737, 1690

Chiral HPLC (25 cm Chiralcel OD-H, 5\% EtOH/n-heptane, $1.0 \mathrm{~mL} / \mathrm{min}$, detection at 215 $\mathrm{nm}$ ) $\mathrm{R}_{\mathrm{t}}=11.0 \mathrm{~min}$ (minor) and 12.4 (major), ee $=96.2 \%$.<smiles>CC(c1ccccc1)N1CCCCC1=O</smiles>

\section{1-(1-Phenylethyl)piperidin-2-one 3s}

General procedure A was followed. Iodine $(381 \mathrm{mg}, 1.50 \mathrm{mmol})$ was added to a mixture of $2 \mathrm{~s}(38 \mathrm{mg}, 0.20 \mathrm{mmol})$ and sodium bicarbonate $(168 \mathrm{mg}, 2.00 \mathrm{mmol})$ in $\mathrm{THF} / \mathrm{H}_{2} \mathrm{O}(7.5 / 3.0$ $\mathrm{mL}$ ). Purification was carried out by silica gel chromatography using 10-60\% TBME (with $5 \% \mathrm{MeOH}, 1 \%$ triethylamine modifier)/cyclohexane as the eluant, but the resultant product was impure, so this material was re-purified by $\mathrm{HpH}$ MDAP (method C) to afford 3s (11.1 $\mathrm{mg}, 27 \%$ ) as an amber oil.*

LCMS (High pH, UV, ESI) $\mathrm{R}_{\mathrm{t}}=0.94 \mathrm{~min},[\mathrm{M}+\mathrm{H}]^{+} 204.1$

${ }^{1} \mathrm{H}$ NMR $\left(\mathrm{CDCl}_{3}, 400 \mathrm{MHz}\right): \delta$ 7.23-7.39 (m, 5H), $6.18(\mathrm{q}, J=7.1 \mathrm{~Hz}, 1 \mathrm{H}), 3.12(\mathrm{ddd}, J=12.3$, 8.0, 4.4 Hz, 1H), 2.76-2.86 (m, 1H), 2.50 (t, $J=6.7 \mathrm{~Hz}, 2 \mathrm{H}), 1.71-1.82(\mathrm{~m}, 3 \mathrm{H}), 1.58-1.69$ (m, 1H), $1.53(\mathrm{~d}, J=7.1 \mathrm{~Hz}, 3 \mathrm{H})$

*LCMS shows $13 \%$ area of an unknown artifact at 0.66 min, but no impurity was observed by $N M R$, so the peak was attributed to some small amount of a highly UV active impurity.

\section{1-(4-Methoxybenzyl)-5-methylpiperidin-2-one $\quad 3 t^{\alpha} \quad$ and 1-(4-methoxybenzyl)-3- methylpiperidin-2-one $3 \mathrm{t}^{\beta}$}

General procedure A was followed. Iodine $(952 \mathrm{mg}, 3.75 \mathrm{mmol})$ was added to a mixture of $2 \mathrm{t}(110 \mathrm{mg}, 0.50 \mathrm{mmol})$ and sodium bicarbonate $(420 \mathrm{mg}, 5.00 \mathrm{mmol})$ in $\mathrm{THF} / \mathrm{H}_{2} \mathrm{O}(14.3 / 5.7$ $\mathrm{mL}$ ). Purification was carried out by silica gel chromatography using 0-50\% TBME (with $1 \% \mathrm{Et}_{3} \mathrm{~N} \& 5 \% \mathrm{MeOH}$ modifier)/cyclohexane as the eluant, with $15 \mathrm{~min}$ isochratically at $40 \%$ TBME (with 1\% triethylamine \& 5\% methanol modifier)/cyclohexane to afford $\mathbf{3 t}^{\boldsymbol{a}}$ $(21.6 \mathrm{mg}, 19 \%)$ as a colorless oil, and $\mathbf{3 t}^{\boldsymbol{\beta}}(22.7 \mathrm{mg}, 19 \%)$ as a colorless oil.*<smiles>COc1ccc(CN2CC(C)CCC2=O)cc1</smiles>

\section{1-(4-Methoxybenzyl)-5-methylpiperidin-2-one $3 t^{\alpha}$}

LCMS (High pH, UV, ESI) $\mathrm{R}_{\mathrm{t}}=0.96 \mathrm{~min},[\mathrm{M}+\mathrm{H}]^{+} 234.1$ 
${ }^{1} \mathrm{H}$ NMR $\left(\mathrm{CDCl}_{3}, 400 \mathrm{MHz}\right): \delta 7.19(\mathrm{~d}, J=8.6 \mathrm{~Hz}, 2 \mathrm{H}), 6.86(\mathrm{~d}, J=8.6 \mathrm{~Hz}, 2 \mathrm{H}), 4.59$ (d, $J=14.4 \mathrm{~Hz}, 1 \mathrm{H}), 4.44(\mathrm{~d}, J=14.4 \mathrm{~Hz}, 1 \mathrm{H}), 3.80$ (s, 3H), 3.16 (ddd, $J=12.0,5.1,1.9 \mathrm{~Hz}, 1 \mathrm{H}$ ), $2.81(\mathrm{dd}, J=11.9,10.4 \mathrm{~Hz}, 1 \mathrm{H}), 2.53$ (ddd, $J=17.9,5.8,3.0 \mathrm{~Hz}, 1 \mathrm{H}), 2.42$ (ddd, $J=17.9,11.4$, $6.6 \mathrm{~Hz}, 1 \mathrm{H}), 1.79-1.98(\mathrm{~m}, 2 \mathrm{H}), 1.45$ (dtd, $J=13.1,11.3,5.9 \mathrm{~Hz}, 1 \mathrm{H}), 0.95$ (d, $J=6.6 \mathrm{~Hz}, 3 \mathrm{H})$.<smiles>COc1ccc(CN2CCCC(C)C2=O)cc1</smiles>

LCMS (High pH, UV, ESI) $\mathrm{R}_{\mathrm{t}}=0.97 \mathrm{~min},[\mathrm{M}+\mathrm{H}]^{+} 234.1$

${ }^{1} \mathrm{H}$ NMR $\left(\mathrm{CDCl}_{3}, 400 \mathrm{MHz}\right): \delta 7.19(\mathrm{~d}, J=8.6 \mathrm{~Hz}, 2 \mathrm{H}), 6.86(\mathrm{~d}, J=8.8 \mathrm{~Hz}, 2 \mathrm{H}), 4.60(\mathrm{~d}$, $J=14.4 \mathrm{~Hz}, 1 \mathrm{H}), 4.44$ (d, J=14.4 Hz, 1H), 3.80 (s, 3H), 3.20 (dd, J=7.3, $5.1 \mathrm{~Hz}, 2 \mathrm{H}), 2.40$ $2.53(\mathrm{~m}, 1 \mathrm{H}), 1.96(\mathrm{dtd}, J=12.9,6.3,3.3 \mathrm{~Hz}, 1 \mathrm{H}), 1.79-1.88(\mathrm{~m}, 1 \mathrm{H}), 1.71$ (dddt, $J=17.2$, 10.4, 6.9, 3.4 Hz, 1H), 1.47-1.57 (m, 1H), 1.29 (d, $J=7.3 \mathrm{~Hz}, 3 \mathrm{H})$.

*LCMS shows $13 \%$ area of an unknown artifact at 1.12 min, but no impurity was observed by NMR, so the peak was attributed to some small amount of a highly UV active impurity.<smiles>CCOC(=O)C1CCC(=O)N1Cc1ccccc1</smiles>

\section{Ethyl 1-benzyl-5-oxopyrrolidine-2-carboxylate 3u}

General procedure A was followed. Iodine $(761 \mathrm{mg}, 3.00 \mathrm{mmol})$ was added to a mixture of $N$-benzyl-L-proline ethyl ester $(44.5 \mu \mathrm{L}, 0.20 \mathrm{mmol}), N$-benzyl-D-proline ethyl ester $(44.5$ $\mu \mathrm{L}, 0.20 \mathrm{mmol}$ ) and sodium bicarbonate $(336 \mathrm{mg}, 4.00 \mathrm{mmol})$ in $\mathrm{THF} / \mathrm{H}_{2} \mathrm{O}(11.4 / 4.6 \mathrm{~mL})$. Purification was carried out by silica gel chromatography using 0-50\% (3:1 EtOAc/EtOH) (with 1\% triethylamine modifier)/cyclohexane as the eluent, to afford $\mathbf{3 u}(54.7 \mathrm{mg}, 55 \%$ ) as a colorless oil.

LCMS (Low pH, UV, ESI) $\mathrm{R}_{\mathrm{t}}=0.92 \mathrm{~min},[\mathrm{M}+\mathrm{H}]^{+} 248.2$

${ }^{1} \mathrm{H}$ NMR $\left(\mathrm{CDCl}_{3}, 400 \mathrm{MHz}\right): \delta$ 7.27-7.36 (m, 3H), 7.20-7.24 (m, 2H), $5.03(\mathrm{~d}, J=14.7 \mathrm{~Hz}$, $1 \mathrm{H}), 4.08-4.21(\mathrm{~m}, 2 \mathrm{H}), 4.01(\mathrm{~d}, J=14.9 \mathrm{~Hz}, 1 \mathrm{H}), 3.97$ (dd, $J=9.0,3.2 \mathrm{~Hz}, 1 \mathrm{H}), 2.53-2.63$ (m, $1 \mathrm{H}), 2.42$ (ddd, $J=16.9,9.5,3.7 \mathrm{~Hz}, 1 \mathrm{H}), 2.19-2.31(\mathrm{~m}, 1 \mathrm{H}), 2.08$ (ddt, $J=13.1,9.6,3.5 \mathrm{~Hz}$, $1 \mathrm{H}), 1.25$ (t, $J=7.1 \mathrm{~Hz}, 3 \mathrm{H})$.<smiles>Cc1nc2n(c(=O)c1CCN1CCC(c3noc4cc(F)ccc34)CC1=O)CCCC2</smiles>

Oxo-risperidone 5a 
General procedure B was followed. Iodine $(190 \mathrm{mg}, 0.75 \mathrm{mmol})$ was added to a mixture of rispoeridone $(41 \mathrm{mg}, 0.10 \mathrm{mmol})$ and sodium bicarbonate $(84 \mathrm{mg}, 1.00 \mathrm{mmol})$ in $\mathrm{THF} / \mathrm{H}_{2} \mathrm{O}$ $(2.9 / 1.1 \mathrm{~mL}$ ). Purification was carried out by high pH MDAP (Method B), to afford 5a (24.1 $\mathrm{mg}, 57 \%$ ) as a pale brown solid.

LCMS (High pH, UV, ESI) $\mathrm{R}_{\mathrm{t}}=0.88 \mathrm{~min},[\mathrm{M}+\mathrm{H}]^{+} 425.3$

${ }^{1} \mathrm{H}$ NMR (DMSO-d $\left.6,400 \mathrm{MHz}\right): \delta 8.06(\mathrm{dd}, J=8.7,5.3 \mathrm{~Hz}, 1 \mathrm{H}), 7.70(\mathrm{dd}, J=9.3,2.2 \mathrm{~Hz}, 1 \mathrm{H})$, $7.30(\mathrm{td}, J=9.0,2.2 \mathrm{~Hz}, 1 \mathrm{H}), 3.76-3.81(\mathrm{~m}, 2 \mathrm{H}), 3.69-3.76(\mathrm{~m}, 1 \mathrm{H}), 3.46-3.55(\mathrm{~m}, 1 \mathrm{H}), 3.33-$ $3.42(\mathrm{~m}, 3 \mathrm{H}), 2.76(\mathrm{t}, J=6.6 \mathrm{~Hz}, 2 \mathrm{H}), 2.70(\mathrm{dd}, J=5.7,1.3 \mathrm{~Hz}, 1 \mathrm{H}), 2.62-2.68(\mathrm{~m}, 2 \mathrm{H}), 2.55-$ $2.62(\mathrm{~m}, 1 \mathrm{H}), 2.26-2.34(\mathrm{~m}, 1 \mathrm{H}), 2.23(\mathrm{~s}, 3 \mathrm{H}), 2.02-2.13(\mathrm{~m}, 1 \mathrm{H}), 1.81-1.89(\mathrm{~m}, 2 \mathrm{H}), 1.72-$ $1.80(\mathrm{~m}, 2 \mathrm{H})$

${ }^{13} \mathrm{C}$ NMR (DMSO-d $\left.6,126 \mathrm{MHz}\right): \delta 167.2,163.6(\mathrm{~d}, J=13.9 \mathrm{~Hz}), 163.2,163.0,161.2(\mathrm{~d}$, $J=231.2 \mathrm{~Hz}$ ), 158.8, 158.8, 156.9, 124.3 (d, $J=12.0 \mathrm{~Hz}$ ), 117.4 (d, $J=3.7 \mathrm{~Hz}), 113.1$ (d, $J=25.0$ Hz), 97.9 (d, $J=27.7$ Hz), 46.6, 45.4, 42.6, 36.1, 31.2, 30.8, 27.5, 24.0, 21.8, 21.3, 19.0

$v_{\max }\left(\mathrm{cm}^{-1}\right)$ (thin film): 3060, 2959, 1658, 1635

HRMS: Calculated for $\mathrm{C}_{23} \mathrm{H}_{26} \mathrm{~F} \mathrm{~N}_{4} \mathrm{O}_{3}$ 425.1983, found $[\mathrm{M}+\mathrm{H}]^{+}: 425.1977$ (-1.6 ppm).

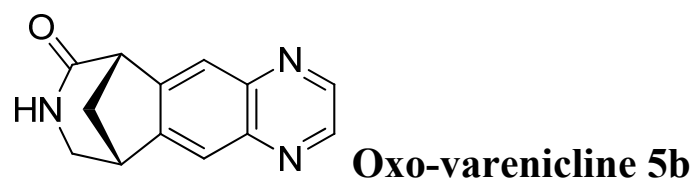

General procedure A was followed. Iodine $(190 \mathrm{mg}, 0.75 \mathrm{mmol})$ was added to a mixture of varenicline hydrochloride $(25 \mathrm{mg}, 0.10 \mathrm{mmol})$ and sodium bicarbonate $(84 \mathrm{mg}, 1.00 \mathrm{mmol})$ in $\mathrm{THF} / \mathrm{H}_{2} \mathrm{O}(2.9 / 1.1 \mathrm{~mL})$. Purification was carried out by reverse phase flash chromatography using $0-30 \%$ Acetonitrile $/ 10 \mathrm{mM}$ aqueous ammonium bicarbonate to afford $\mathbf{5 b}(11.9 \mathrm{mg}, 53 \%)$ as a white solid.

LCMS (High pH, UV, ESI) $\mathrm{R}_{\mathrm{t}}=0.56 \mathrm{~min},[\mathrm{M}+\mathrm{H}]^{+} 226.2$

${ }^{1} \mathrm{H} \mathrm{NMR}\left(\mathrm{CDCl}_{3}, 400 \mathrm{MHz}\right): \delta 8.81(\mathrm{dd}, J=9.3,2.0 \mathrm{~Hz}, 2 \mathrm{H}), 8.04(\mathrm{~d}, J=13.0 \mathrm{~Hz}, 2 \mathrm{H}), 5.14$ (br. s., 1H), 3.91 (d, $J=3.9 \mathrm{~Hz}, 1 \mathrm{H}), 3.84$ (ddd, $J=11.1,4.3,1.2 \mathrm{~Hz}, 1 \mathrm{H}), 3.72$ (t, $J=4.3 \mathrm{~Hz}$, $1 \mathrm{H}), 3.37$ (ddt, $J=11.1,2.4,1.0 \mathrm{~Hz}, 1 \mathrm{H}), 2.59-2.66$ (m, 1H), 2.51 (d, $J=11.5 \mathrm{~Hz}, 1 \mathrm{H})$

${ }^{13} \mathrm{C} \mathrm{NMR}\left(\mathrm{CDCl}_{3}, 101 \mathrm{MHz}\right): \delta 171.9,147.8,146.8,144.5,144.3,143.5,143.3,123.1,122.6$, $49.2,48.2,38.9,37.7$

$v_{\max }\left(\mathrm{cm}^{-1}\right)$ (thin film): 3196, 2969, 1657

HRMS: Calculated for $\mathrm{C}_{13} \mathrm{H}_{12} \mathrm{~N}_{3} \mathrm{O} 226.0975$, found $[\mathrm{M}+\mathrm{H}]^{+}: 226.0977$ (0.8 ppm). 
<smiles>COc1ccc2c(c1)CCC(c1ccccc1)=C2c1ccc(OCCN2CCCC2=O)cc1</smiles>

\section{Oxo-nafoxidine 5c}

General procedure A was followed. Iodine $(95 \mathrm{mg}, 0.38 \mathrm{mmol})$ was added to a mixture of nafoxidine hydrochloride ( $23 \mathrm{mg}, 0.05 \mathrm{mmol}$ ) and sodium bicarbonate $(42 \mathrm{mg}, 0.50 \mathrm{mmol})$ in $\mathrm{THF} / \mathrm{H}_{2} \mathrm{O}(1.4 / 0.6 \mathrm{~mL})$. Purification was carried out by silica gel chromatography using 10$45 \%$ EtOAc/cyclohexane as the eluent, to afford 5c (20.2 mg, 92\%) as a white solid.*

LCMS (High pH, UV, ESI) $\mathrm{R}_{\mathrm{t}}=1.42 \mathrm{~min},[\mathrm{M}+\mathrm{H}]^{+} 440.2$

${ }^{1} \mathrm{H}$ NMR $\left(\mathrm{CDCl}_{3}, 400 \mathrm{MHz}\right): \delta$ 7.09-7.14 (m, 2H), 7.00-7.07 (m, 3H), 6.97 (d, J=8.8 Hz, 2H), 6.70-6.80 (m, 4H), 6.60 (dd, J=8.6, $2.8 \mathrm{~Hz}, 1 \mathrm{H}), 4.09$ (t, $J=5.2 \mathrm{~Hz}, 2 \mathrm{H}), 3.81(\mathrm{~s}, 3 \mathrm{H}), 3.67$ (t, $J=5.2 \mathrm{~Hz}, 2 \mathrm{H}), 3.59$ (t, $J=7.1 \mathrm{~Hz}, 2 \mathrm{H}), 2.95$ (dd, $J=8.6,7.1 \mathrm{~Hz}, 2 \mathrm{H}), 2.78$ (dd, $J=8.6,6.3 \mathrm{~Hz}$, 2H), 2.40 (t, $J=8.1 \mathrm{~Hz}, 2 \mathrm{H}$ ), 2.03 (quin, $J=7.6 \mathrm{~Hz}, 2 \mathrm{H}$ )

${ }^{13} \mathrm{C} \mathrm{NMR}\left(\mathrm{CDCl}_{3}, 101 \mathrm{MHz}\right): \delta 175.3,158.5,157.0,143.3,137.7,134.6,134.5,132.6,132.2$, $130.4,128.3,127.6,127.4,125.7,113.9,113.2$, 110.8, 66.5, 55.3, 49.0, 42.5, 30.8, 30.8, 29.0, 18.2

$v_{\max }\left(\mathrm{cm}^{-1}\right)$ (thin film): 2930, 2833, 1681

HRMS: Calculated for $\mathrm{C}_{29} \mathrm{H}_{30} \mathrm{NO}_{3} 440.2220$, found $[\mathrm{M}+\mathrm{H}]^{+}: 440.2219$ (-0.4 ppm).

${ }^{*}{ }^{1} H$ NMR analysis showed presence of $4 w t \%$ of an oxidized product - likely to arise from aromatization of the fused cyclohexene ring<smiles>Cc1ccc(C(=CCN2CCCC2=O)c2cccc(C=CC(=O)O)n2)cc1</smiles>

General procedure A was followed. Iodine $(190 \mathrm{mg}, 0.75 \mathrm{mmol})$ was added to a mixture of acrivastine $(35 \mathrm{mg}, 0.10 \mathrm{mmol})$ and sodium bicarbonate $(84 \mathrm{mg}, 1.00 \mathrm{mmol})$ in $\mathrm{THF} / \mathrm{H}_{2} \mathrm{O}$ $(2.9 / 1.1 \mathrm{~mL}) .{ }^{1} \mathrm{H}$ NMR analysis of the crude material showed $56 \%$ conversion to $5 \mathrm{~d}$ based on the peak at $2.21 \mathrm{ppm}$ against hexamethyldisiloxane $(24.0 \mu \mathrm{mol})$ as a standard. Purification was carried out by reverse phase preparative HPLC using 15-55\% $\mathrm{MeCN}$ (with $0.1 \%$ ammonia modifier) $/ 10 \mathrm{mM}$ aqueous ammonium bicarbonate as the eluent, to afford $\mathbf{5 d}(5.6$ $\mathrm{mg}, 15 \%)$ as a brown solid.*

LCMS (High pH, UV, ESI) $\mathrm{R}_{\mathrm{t}}=0.74 \mathrm{~min},[\mathrm{M}+\mathrm{H}]^{+} 363.2$

${ }^{1} \mathrm{H}$ NMR (DMSO-d $6,400 \mathrm{MHz}$ ): $\delta 7.74$ (t, $\left.J=7.6 \mathrm{~Hz}, 1 \mathrm{H}\right), 7.57$ (d, J=8.1 Hz, 1H), 7.57 (d, $J=15.7 \mathrm{~Hz}, 1 \mathrm{H}), 7.29$ (d, $J=8.1 \mathrm{~Hz}, 2 \mathrm{H}), 7.14$ (d, $J=8.1 \mathrm{~Hz}, 2 \mathrm{H}), 6.91$ (d, $J=7.6 \mathrm{~Hz}, 1 \mathrm{H}), 6.83$ 
$(\mathrm{d}, J=15.7 \mathrm{~Hz}, 1 \mathrm{H}), 6.78(\mathrm{t}, J=6.9 \mathrm{~Hz}, 1 \mathrm{H}), 3.85(\mathrm{~d}, J=7.1 \mathrm{~Hz}, 2 \mathrm{H}), 3.30(\mathrm{t}, J=7.1 \mathrm{~Hz}, 3 \mathrm{H})$, $2.38(\mathrm{~s}, 3 \mathrm{H}), 2.21$ (t, $J=8.1 \mathrm{~Hz}, 2 \mathrm{H}), 1.91$ (quin, $J=7.5 \mathrm{~Hz}, 2 \mathrm{H}$ )

${ }^{13} \mathrm{C}$ NMR (DMSO-d $\left.6,126 \mathrm{MHz}\right): \delta 174.1,167.6^{[\mathrm{a}]} 157.4,152.3,143.3,142.7,138.3,137.3$, $134.5,129.8,129.7,127.9,123.3,122.9,55.4,46.8,41.5,30.7,21.3,17.8$

${ }^{[a]}$ Peak not seen in $1 D^{13}$ C spectrum, coupling seen to this chemical shift in HMBC.

$v_{\max }\left(\mathrm{cm}^{-1}\right)$ (thin film): $3380(\mathrm{br}), 2923,1678,1643$

HRMS: Calculated for $\mathrm{C}_{22} \mathrm{H}_{23} \mathrm{~N}_{2} \mathrm{O}_{3} 363.1703$, found $[\mathrm{M}+\mathrm{H}]^{+}: 363.1703$ (-0.1 ppm).

*LCMS shows 7\% area of an unknown artifact at $0.73 \mathrm{~min}$, but no impurity was observed by NMR, so the peak was attributed to some small amount of a highly UV active impurity.<smiles>CCCc1nc(C)c2c(=O)[nH]c(-c3cc(S(=O)(=O)N4CCN(CC)C(=O)C4)ccc3OCC)nn12</smiles>

\section{Oxo-vardenafil 5e}

General procedure B was followed. Iodine $(190 \mathrm{mg}, 0.75 \mathrm{mmol})$ was added to a mixture of vardenafil hydrochloride trihydrate $(58 \mathrm{mg}, 0.10 \mathrm{mmol})$ and sodium bicarbonate $(84 \mathrm{mg}, 1.00$ $\mathrm{mmol})$ in $\mathrm{THF} / \mathrm{H}_{2} \mathrm{O}(2.9 / 1.1 \mathrm{~mL}) .{ }^{1} \mathrm{H} \mathrm{NMR}$ analysis of the crude material showed $57 \%$ conversion to $5 \mathbf{e}$ based on the peak at $3.66 \mathrm{ppm}$ against hexamethyldisiloxane $(24.0 \mu \mathrm{mol})$ as a standard. Purification was carried out by high pH MDAP (Method C), to afford 5e (13.2 $\mathrm{mg}, 26 \%$ ) as a white solid.

LCMS (High pH, UV, ESI) $\mathrm{R}_{\mathrm{t}}=0.93 \mathrm{~min},[\mathrm{M}+\mathrm{H}]^{+} 503.3$

${ }^{1} \mathrm{H}$ NMR $\left(\mathrm{CDCl}_{3}, 400 \mathrm{MHz}\right): \delta 9.70$ (br. s., $\left.1 \mathrm{H}\right), 8.48$ (d, $\left.J=2.4 \mathrm{~Hz}, 1 \mathrm{H}\right), 7.92$ (dd, $J=8.8,2.4$ $\mathrm{Hz}, 1 \mathrm{H}), 7.19$ (d, $J=8.8 \mathrm{~Hz}, 1 \mathrm{H}), 4.35$ (q, $J=6.9 \mathrm{~Hz}, 2 \mathrm{H}), 3.72(\mathrm{~s}, 2 \mathrm{H}), 3.34-3.47$ (m, 6H), $3.01(\mathrm{t}, J=7.6 \mathrm{~Hz}, 2 \mathrm{H}), 2.64(\mathrm{~s}, 3 \mathrm{H}), 1.89$ (dq, $J=14.9,7.5 \mathrm{~Hz}, 2 \mathrm{H}), 1.60$ (t, $J=7.0 \mathrm{~Hz}, 3 \mathrm{H})$, 1.09 (t, $J=7.2 \mathrm{~Hz}, 3 \mathrm{H}), 1.04(\mathrm{t}, J=7.3 \mathrm{~Hz}, 3 \mathrm{H})$

${ }^{13} \mathrm{C} \mathrm{NMR}\left(\mathrm{CDCl}_{3}, 101 \mathrm{MHz}\right): \delta 163.1,160.3,154.5,146.5,144.3,140.4,132.5,130.3,128.4$, $119.1,113.6,113.4,66.2,48.8,45.5,43.1,41.7,27.9,20.9,14.5,14.4,14.0,12.0$

$v_{\max }\left(\mathrm{cm}^{-1}\right)$ (thin film): 3533 (br), 3325, 2968, 1697, 1641

HRMS: Calculated for $\mathrm{C}_{23} \mathrm{H}_{31} \mathrm{~N}_{6} \mathrm{O}_{5} \mathrm{~S} 503.2071$, found $[\mathrm{M}+\mathrm{H}]^{+}: 503.2073$ (0.3 ppm). 


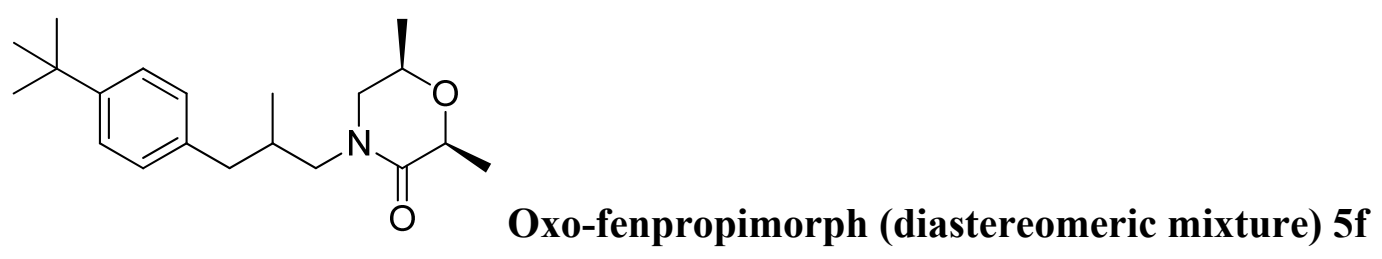

General procedure B was followed. Iodine $(190 \mathrm{mg}, 0.75 \mathrm{mmol})$ was added to a mixture of fenpropimorph (30 mg, $0.10 \mathrm{mmol}$ ) and sodium bicarbonate $(84 \mathrm{mg}, 1.00 \mathrm{mmol})$ in THF/ $\mathrm{H}_{2} \mathrm{O}$ $(2.9 / 1.1 \mathrm{~mL})$. Purification was carried out by silica gel chromatography using $0-25 \% \mathrm{TBME}$ (with 1\% triethylamine \& 5\% methanol modifier)/cyclohexane as the eluent, to afford $\mathbf{5 f}$ (17.6 mg, 55\%) (dr 1.2:1) as a colorless oil.

LCMS (High pH, UV, ESI) $\mathrm{R}_{\mathrm{t}}=1.38 \mathrm{~min},[\mathrm{M}+\mathrm{H}]^{+} 318.3$

${ }^{1} \mathrm{H}$ NMR $\left(\mathrm{CDCl}_{3}, 400 \mathrm{MHz}\right): \delta 7.30(\mathrm{dd}, J=8.4,2.3 \mathrm{~Hz}, 4 \mathrm{H}), 7.09$ (d, $\left.J=8.3 \mathrm{~Hz}, 4 \mathrm{H}\right), 4.20$ (q, $J=6.8 \mathrm{~Hz}, 1 \mathrm{H}), 4.13(\mathrm{q}, J=6.8 \mathrm{~Hz}, 1 \mathrm{H}), 3.76-3.85$ (m, 1H), 3.58-3.67 (m, 1H), 3.14-3.41 (m, 6H), 3.07 (dd, $J=12.0,2.7 \mathrm{~Hz}, 1 \mathrm{H}), 2.99$ (dd, $J=11.7,2.7 \mathrm{~Hz}, 1 \mathrm{H}), 2.56-2.66$ (m, 2H), 2.44$2.52(\mathrm{~m}, J=7.3 \mathrm{~Hz}, 1 \mathrm{H}), 2.39$ (dd, $J=13.7,8.6 \mathrm{~Hz}, 1 \mathrm{H}), 2.18(\mathrm{dq}, J=14.9,7.6 \mathrm{~Hz}, 2 \mathrm{H}), 1.45$ (dd, $J=6.8,2.4 \mathrm{~Hz}, 6 \mathrm{H}), 1.32$ (s, 18H), 1.23 (dd, $J=15.4,6.1 \mathrm{~Hz}, 6 \mathrm{H}), 0.89$ (t, $J=7.0 \mathrm{~Hz}, 6 \mathrm{H}$ )

${ }^{13} \mathrm{C} \mathrm{NMR}\left(\mathrm{CDCl}_{3}, 151 \mathrm{MHz}\right): \delta 170.0,169.9,148.8,148.7,137.3,137.2,128.6,128.5,125.1$, $125.1,74.2,74.2,68.9,68.6,53.8,53.4,52.7,52.3,40.8,40.3,34.3,32.9,32.6,31.4,18.5$, $18.4,18.4,18.3,17.6,17.5$

$v_{\max }\left(\mathrm{cm}^{-1}\right)$ (thin film): 2962, 2870, 1652

HRMS: Calculated for $\mathrm{C}_{20} \mathrm{H}_{32} \mathrm{NO}_{2}$ 318.2428, found $[\mathrm{M}+\mathrm{H}]^{+}: 318.2429$ (0.5 ppm).

\section{7-Oxo-azelastine $5 \mathrm{~g}^{\alpha}$ and 2-oxo-azelastine $5 \mathrm{~g}^{\beta}$}

General procedure A was followed. Iodine $(190 \mathrm{mg}, 0.75 \mathrm{mmol})$ was added to a mixture of azelastine hydrochloride (42 $\mathrm{mg}, 0.10 \mathrm{mmol})$ and sodium bicarbonate $(84 \mathrm{mg}, 1.00 \mathrm{mmol})$ in $\mathrm{THF} / \mathrm{H}_{2} \mathrm{O}(2.9 / 1.1 \mathrm{~mL})$. Purification was carried out by silica gel chromatography using 0 $25 \%$ (3:1 EtOAc/EtOH, with 1\% triethylamine modifier)/cyclohexane as the eluent, to afford a co-eluting mixture of $\mathbf{5 g}^{\boldsymbol{\alpha}}$ and $\mathbf{5 g}^{\boldsymbol{\beta}}(26.9 \mathrm{mg}, 68 \% *)$, in $4.3: 1$ ratio of $\mathbf{5 g}^{\boldsymbol{\alpha}} \mathbf{:} \mathbf{5 g}^{\mathbf{\beta}}$, determined by ${ }^{1} \mathrm{H}$ NMR. The isomers were only separable by high $\mathrm{pH}$ MDAP (Method C) to afford $\mathbf{5 \mathbf { g } ^ { \boldsymbol { \alpha } }}$ $(14.8 \mathrm{mg}, 37 \%)$ as a white solid and $\mathbf{5 g}^{\boldsymbol{\beta}}(2.2 \mathrm{mg}, 6 \%)$ as a white solid.

*Based on $30.6 \mathrm{mg}$ isolated yield, with $12.1 \mathrm{wt} \%$ cyclohexane impurity by ${ }^{1} \mathrm{H} N \mathrm{NR}$.<smiles>CN1CCC(n2nc(Cc3ccc(Cl)cc3)c3ccccc3c2=O)CCC1=O</smiles>

7-Oxo-azelastine $5 \mathrm{~g}^{\alpha}$ 
LCMS (High pH, UV, ESI) $\mathrm{R}_{\mathrm{t}}=1.10 \mathrm{~min},[\mathrm{M}+\mathrm{H}]^{+} 396.2$

${ }^{1} \mathrm{H}$ NMR $\left(\mathrm{CDCl}_{3}, 400 \mathrm{MHz}\right): \delta 8.44-8.52(\mathrm{~m}, 1 \mathrm{H}), 7.66-7.77(\mathrm{~m}, 3 \mathrm{H}), 7.26-7.30(\mathrm{~m}, 2 \mathrm{H})$, 7.19 (d, $J=8.3 \mathrm{~Hz}, 2 \mathrm{H}), 5.27$ (tt, $J=11.4,4.4 \mathrm{~Hz}, 1 \mathrm{H}), 4.27$ (s, 2H), 3.76 (dd, $J=15.7,10.3 \mathrm{~Hz}$, $1 \mathrm{H}), 3.33$ (ddd, $J=15.5,6.2,1.3 \mathrm{~Hz}, 1 \mathrm{H}), 3.08(\mathrm{~s}, 3 \mathrm{H}), 2.64-2.78(\mathrm{~m}, 2 \mathrm{H}), 2.11-2.25(\mathrm{~m}, 2 \mathrm{H})$, 2.02-2.11 ppm (m, 2H)

${ }^{13} \mathrm{C} \mathrm{NMR}\left(\mathrm{CDCl}_{3}, 151 \mathrm{MHz}\right): \delta 174.7,158.5,144.8,136.2,133.0,132.7,131.3,129.8,128.9$, $128.6,128.1,127.6,124.7,57.3,48.5,38.3,35.8,33.8,32.4,28.1$

$v_{\max }\left(\mathrm{cm}^{-1}\right)($ thin film): 2939, 1635

HRMS: Calculated for $\mathrm{C}_{22} \mathrm{H}_{23} \mathrm{ClN}_{3} \mathrm{O}_{2}$ 396.1473, found $[\mathrm{M}+\mathrm{H}]^{+}: 396.1485$ (3.0 ppm).<smiles>CN1CCCC(n2nc(Cc3ccc(Cl)cc3)c3ccccc3c2=O)CC1=O</smiles>

\section{2-Oxo-azelastine $5 g^{\beta}$}

LCMS (High pH, UV, ESI) $\mathrm{R}_{\mathrm{t}}=1.16 \mathrm{~min},[\mathrm{M}+\mathrm{H}]^{+} 396.2$

${ }^{1} \mathrm{H}$ NMR $\left(\mathrm{CDCl}_{3}, 400 \mathrm{MHz}\right): \delta$ 8.43-8.49 (m, 1H), 7.69-7.74 (m, 2H), 7.64-7.69 (m, 1H), $7.28(\mathrm{~d}, J=8.6 \mathrm{~Hz}, 2 \mathrm{H}), 7.19(\mathrm{~d}, J=8.6 \mathrm{~Hz}, 2 \mathrm{H}), 5.22-5.31(\mathrm{~m}, 1 \mathrm{H}), 4.26(\mathrm{~s}, 2 \mathrm{H}), 3.66$ (dd, $J=14.9,10.3 \mathrm{~Hz}, 1 \mathrm{H}), 3.26-3.37$ (m, 2H), 3.05 (s, 3H), 2.76 (dt, J=13.8, $1.9 \mathrm{~Hz}, 1 \mathrm{H}), 2.15-$ $2.23(\mathrm{~m}, 1 \mathrm{H}), 1.95-2.11(\mathrm{~m}, 2 \mathrm{H}), 1.74-1.87(\mathrm{~m}, 1 \mathrm{H})$

${ }^{13} \mathrm{C} \mathrm{NMR}\left(\mathrm{CDCl}_{3}, 101 \mathrm{MHz}\right): \delta 172.4,158.2,144.6,136.2,132.9,132.6,131.3,129.8,128.8$, $128.6,128.2,127.6,124.7,52.3,50.7,42.6,38.4,36.0,34.9,26.2$

$v_{\max }\left(\mathrm{cm}^{-1}\right)($ thin film): 2926, 1646

HRMS: Calculated for $\mathrm{C}_{22} \mathrm{H}_{23} \mathrm{ClN}_{3} \mathrm{O}_{2} 39.1473$, found $[\mathrm{M}+\mathrm{H}]^{+}: 396.1475$ (0.3 ppm).<smiles>CC1CCN(CCCC(=O)c2ccc(F)cc2)C(=O)C1</smiles>

\section{Oxo-melperone 5h}

General procedure A was followed. Iodine $(190 \mathrm{mg}, 0.75 \mathrm{mmol})$ was added to a mixture of melperone hydrochloride (30 $\mathrm{mg}, 0.10 \mathrm{mmol}$ ) and sodium bicarbonate $(84 \mathrm{mg}, 1.00 \mathrm{mmol})$ in $\mathrm{THF} / \mathrm{H}_{2} \mathrm{O}(2.9 / 1.1 \mathrm{~mL})$. Purification was carried out by silica gel chromatography using 0$60 \%$ TBME (with 1\% triethylamine, 5\% methanol modifier)/cyclohexane as the eluent, to afford $\mathbf{5 h}(23.0 \mathrm{mg}, 83 \%)$ as a white solid.

LCMS (High pH, UV, ESI) $\mathrm{R}_{\mathrm{t}}=1.00 \mathrm{~min},[\mathrm{M}+\mathrm{H}]^{+} 278.2$ 
${ }^{1} \mathrm{H}$ NMR $\left(\mathrm{CDCl}_{3}, 400 \mathrm{MHz}\right): \delta 7.97(\mathrm{dd}, J=9.0,5.4 \mathrm{~Hz}, 2 \mathrm{H}), 7.11(\mathrm{t}, J=8.6 \mathrm{~Hz}, 2 \mathrm{H}), 3.47-$ $3.55(\mathrm{~m}, 1 \mathrm{H}), 3.36-3.44(\mathrm{~m}, 1 \mathrm{H}), 3.32(\mathrm{~d}, J=4.0 \mathrm{~Hz}, 1 \mathrm{H}), 3.29-3.31(\mathrm{~m}, 1 \mathrm{H}), 2.97$ (t, $J=7.1$ $\mathrm{Hz}, 2 \mathrm{H}), 2.40$ (dtd, $J=11.9,10.1,1.8 \mathrm{~Hz}, 1 \mathrm{H}), 1.99$ (quind, $J=7.1,1.8 \mathrm{~Hz}, 2 \mathrm{H}), 1.81-1.93$ (m, $3 \mathrm{H}), 1.36-1.48(\mathrm{~m}, 1 \mathrm{H}), 0.97(\mathrm{~d}, J=6.3 \mathrm{~Hz}, 3 \mathrm{H})$

${ }^{13} \mathrm{C} \mathrm{NMR}\left(\mathrm{CDCl}_{3}, 101 \mathrm{MHz}\right): \delta 198.0,169.7,165.7(\mathrm{~d}, J=258.0 \mathrm{~Hz}), 133.3(\mathrm{~d}, J=3.2 \mathrm{~Hz})$, $130.7(\mathrm{~d}, J=9.6 \mathrm{~Hz}), 115.6(\mathrm{~d}, J=22.4 \mathrm{~Hz}), 46.8,46.0,40.5,35.6,31.0,27.9,21.5,21.0$

$v_{\max }\left(\mathrm{cm}^{-1}\right)$ (thin film): 2950, 2869, 1684, 1627

HRMS: Calculated for $\mathrm{C}_{16} \mathrm{H}_{21} \mathrm{FNO}_{2} 278.1551$, found $[\mathrm{M}+\mathrm{H}]^{+}: 278.1553$ (0.7 ppm).

\section{Oxo-bepridil 5i and oxo-iodo-bepridil 15}

General procedure A was followed. Iodine $(190 \mathrm{mg}, 0.75 \mathrm{mmol})$ was added to a mixture of bepridil hydrochloride hydrate $(42 \mathrm{mg}, 0.10 \mathrm{mmol})$ and sodium bicarbonate $(84 \mathrm{mg}, 1.00$ $\mathrm{mmol})$ in $\mathrm{THF} / \mathrm{H}_{2} \mathrm{O}(2.9 / 1.1 \mathrm{~mL}) .{ }^{1} \mathrm{H} \mathrm{NMR}$ analysis of the crude material showed $81 \%$ conversion to $\mathbf{5 i}$ and $17 \%$ conversion to $\mathbf{1 5}$ based on peaks at 6.85 and $6.63 \mathrm{ppm}$, respectively, against hexamethyldisiloxane $(24.0 \mu \mathrm{mol})$ as a standard. Purification was attempted initially by silica gel chromatography using 0-50\% EtOAc (with 1\% 4M ammonia in methanol modifier)/cyclohexane, but the products 5i and $\mathbf{1 5}$ co-eluted. Separation could only be achieved by high pH MDAP (Method E), to afford 5i (11.5 mg, 30\%) as a yellow oil, and $\mathbf{1 5}(2.6 \mathrm{mg}, 5 \%)$ as a yellow oil.<smiles>CC(C)COCC(CN(Cc1ccccc1)c1ccccc1)N1CCCC1=O</smiles>

\section{Oxo-bepridil 5i}

LCMS (High pH, UV, ESI) $\mathrm{R}_{\mathrm{t}}=1.40 \mathrm{~min},[\mathrm{M}+\mathrm{H}]^{+} 381.3$

${ }^{1} \mathrm{H} \mathrm{NMR}\left(\mathrm{CDCl}_{3}, 400 \mathrm{MHz}\right): \delta 7.29(\mathrm{t}, J=6.8 \mathrm{~Hz}, 2 \mathrm{H}), 7.15-7.24(\mathrm{~m}, 5 \mathrm{H}), 6.84(\mathrm{~d}, J=8.3 \mathrm{~Hz}$, $2 \mathrm{H}), 6.71(\mathrm{t}, J=7.2 \mathrm{~Hz}, 1 \mathrm{H}), 4.66(\mathrm{~d}, J=16.7 \mathrm{~Hz}, 1 \mathrm{H}), 4.49-4.58(\mathrm{~m}, 2 \mathrm{H}), 3.66(\mathrm{dd}, J=7.2,2.9$ $\mathrm{Hz}, 2 \mathrm{H}), 3.61$ (q, $J=5.1 \mathrm{~Hz}, 1 \mathrm{H}), 3.52(\mathrm{dd}, J=10.1,4.0 \mathrm{~Hz}, 1 \mathrm{H}), 3.40-3.47(\mathrm{~m}, 1 \mathrm{H}), 3.34(\mathrm{td}$, $J=9.0,5.2 \mathrm{~Hz}, 1 \mathrm{H}), 3.11-3.20(\mathrm{~m}, 2 \mathrm{H}), 2.15-2.34(\mathrm{~m}, 2 \mathrm{H}), 1.80-1.93(\mathrm{~m}, 2 \mathrm{H}), 1.66-1.77$ (m, $1 \mathrm{H}), 0.91(\mathrm{dd}, J=6.7,0.9 \mathrm{~Hz}, 6 \mathrm{H})$

${ }^{13} \mathrm{C} \mathrm{NMR}\left(\mathrm{CDCl}_{3}, 101 \mathrm{MHz}\right): \delta 175.4,148.6,138.5,129.2,128.5,126.8,126.7,117.1,113.4$, $78.0,69.8,54.1,49.9,49.6,45.6,31.1,28.6,19.4,18.4$

$v_{\max }\left(\mathrm{cm}^{-1}\right)$ (thin film): 2957, 2872, 1679

HRMS: Calculated for $\mathrm{C}_{24} \mathrm{H}_{33} \mathrm{~N}_{2} \mathrm{O}_{2} 381.2537$, found $[\mathrm{M}+\mathrm{H}]^{+}: 381.2538$ (0.4 ppm). 
<smiles>CC(C)COCC(CN(Cc1ccccc1)c1ccc(I)cc1)N1CCCC1=O</smiles>

\section{Oxo-iodo-bepridil 15}

LCMS (High pH, UV, ESI) $\mathrm{R}_{\mathrm{t}}=1.53 \mathrm{~min},[\mathrm{M}+\mathrm{H}]^{+}$507.1*

${ }^{1} \mathrm{H}$ NMR $\left(\mathrm{CDCl}_{3}, 400 \mathrm{MHz}\right): \delta 7.43(\mathrm{~d}, J=9.1 \mathrm{~Hz}, 2 \mathrm{H}), 7.29(\mathrm{t}, J=7.6 \mathrm{~Hz}, 2 \mathrm{H}), 7.23(\mathrm{t}, J=7.1$ $\mathrm{Hz}, 1 \mathrm{H}), 7.16(\mathrm{~d}, J=7.1 \mathrm{~Hz}, 2 \mathrm{H}), 6.63(\mathrm{~d}, J=9.1 \mathrm{~Hz}, 2 \mathrm{H}), 4.62(\mathrm{~d}, J=17.2 \mathrm{~Hz}, 1 \mathrm{H}), 4.51(\mathrm{~d}$, $J=16.9 \mathrm{~Hz}, 1 \mathrm{H}), 4.44-4.49(\mathrm{~m}, 1 \mathrm{H}), 3.64(\mathrm{~d}, J=7.1 \mathrm{~Hz}, 2 \mathrm{H}), 3.59$ (dd, $J=10.1,5.3 \mathrm{~Hz}, 1 \mathrm{H})$, $3.51(\mathrm{dd}, J=10.1,4.0 \mathrm{~Hz}, 1 \mathrm{H}), 3.31-3.47(\mathrm{~m}, 2 \mathrm{H}), 3.12-3.20(\mathrm{~m}, 2 \mathrm{H}), 2.16-2.34(\mathrm{~m}, 2 \mathrm{H})$, $1.81-1.94(\mathrm{~m}, 2 \mathrm{H}), 1.70-1.80(\mathrm{~m}, 1 \mathrm{H}), 0.91(\mathrm{~d}, J=6.8 \mathrm{~Hz}, 6 \mathrm{H})$

${ }^{13} \mathrm{C} \mathrm{NMR}\left(\mathrm{CDCl}_{3}, 126 \mathrm{MHz}\right): \delta 175.4,147.9,137.9,137.8,128.6,127.0,126.7,115.6,110.0$, $78.0,69.6,54.1,49.8,49.7,45.7,31.0,28.6,19.4,18.4$

$v_{\max }\left(\mathrm{cm}^{-1}\right)$ (thin film): 2956, 2870, 1677

HRMS: Calculated for $\mathrm{C}_{24} \mathrm{H}_{32} \mathrm{IN}_{2} \mathrm{O}_{2}$ 507.1503, found $[\mathrm{M}+\mathrm{H}]^{+}: 507.1518$ (3.0 ppm).

*LCMS analysis shows $12 \%$ area of an unknown impurity with a mass loss of 90 relative to 15 - possibly resulting from some debenzylation of 15 formed in LCMS. No impurity observed in NMR, so likely instability in LCMS.<smiles></smiles>

1-Methyl-5'-(2-( $N$-methylsulfamoyl)ethyl)-2'-oxo-1-azaspiro [bicyclo[2.2.1] heptane-7,3'-indolin]-1-ium iodide 14

General procedure $\mathrm{C}$ was followed. Iodine $(190 \mathrm{mg}, 0.75 \mathrm{mmol})$ was added to a mixture of naratriptan hydrochloride $(37 \mathrm{mg}, 0.10 \mathrm{mmol})$ and sodium bicarbonate $(84 \mathrm{mg}, 1.00 \mathrm{mmol})$ in $\mathrm{THF} / \mathrm{H}_{2} \mathrm{O}(2.9 / 1.1 \mathrm{~mL}) .{ }^{1} \mathrm{H}$ NMR analysis of a $0.6 \mathrm{~mL}$ aliquot from a reaction mixture using $d^{8}-\mathrm{THF} / \mathrm{D}_{2} \mathrm{O}$ as the solvent system showed $52 \%$ conversion to $\mathbf{1 4}$ based on the peak at 2.64 ppm against hexamethyldisiloxane $(9.4 \mu \mathrm{mol})$ as a standard. Purification was carried out by reverse phase preparative HPLC using $0-25 \% \mathrm{MeCN}$ (with $0.1 \%$ ammonia modifier) $/ 10 \mathrm{mM}$ aqueous ammonium bicarbonate as the eluent, to afford $14(11.5 \mathrm{mg}, 24 \%)$ as a white solid.

LCMS (High pH, UV, ESI) $\mathrm{R}_{\mathrm{t}}=0.52 \mathrm{~min},[\mathrm{M}]^{+} 350.1$

${ }^{1} \mathrm{H}$ NMR (D $\left.{ }_{2} \mathrm{O}, 500 \mathrm{MHz}\right): \delta 7.34(\mathrm{~d}, J=8.0 \mathrm{~Hz}, 2 \mathrm{H}), 6.98(\mathrm{~d}, J=8.2 \mathrm{~Hz}, 1 \mathrm{H}), 4.38$ (tt, $J=11.3$, $4.4 \mathrm{~Hz}, 1 \mathrm{H}), 3.91(\mathrm{tt}, J=11.5,4.7 \mathrm{~Hz}, 1 \mathrm{H}), 3.72-3.80$ (m, $1 \mathrm{H}), 3.66$ (ddd, $J=10.8,9.1,5.1 \mathrm{~Hz}$, $1 \mathrm{H}), 3.46(\mathrm{td}, J=7.6,1.8 \mathrm{~Hz}, 2 \mathrm{H}), 3.07$ (t, $J=7.7 \mathrm{~Hz}, 2 \mathrm{H}), 3.01$ (ddt, $J=11.8,8.0,3.8 \mathrm{~Hz}, 1 \mathrm{H})$, 2.89-2.94 (m, 1H), 2.82-2.89 (m, 1H), $2.76(\mathrm{~s}, 3 \mathrm{H}), 2.69$ (s, 3H), 2.12 (ddd, J=13.4, 8.4, 5.1 $\mathrm{Hz}, 1 \mathrm{H}), 1.91$ (ddd, $J=12.9,8.0,4.3 \mathrm{~Hz}, 1 \mathrm{H})^{*}$ 
${ }^{13} \mathrm{C}$ NMR $\left(\mathrm{D}_{2} \mathrm{O}, 101 \mathrm{MHz}\right): \delta 188.5,136.1,135.5,131.4,121.4,115.3,85.5,66.0,65.9,53.9$, 45.1, 43.0, 41.6, 31.6, 31.3, 31.1, 29.7

$v_{\max }\left(\mathrm{cm}^{-1}\right)$ (thin film): 3500-3000 (br), 2973, 1718, 1641

HRMS: Calculated for $\mathrm{C}_{17} \mathrm{H}_{24} \mathrm{~N}_{3} \mathrm{O}_{3} \mathrm{~S} 350.1533$, found [M] $]^{+}: 350.1537$ (1.3 ppm).

* $\mathrm{N}$-H signals not observed in $\mathrm{D}_{2} \mathrm{O}$

\section{Isotopic-labeling experiments}

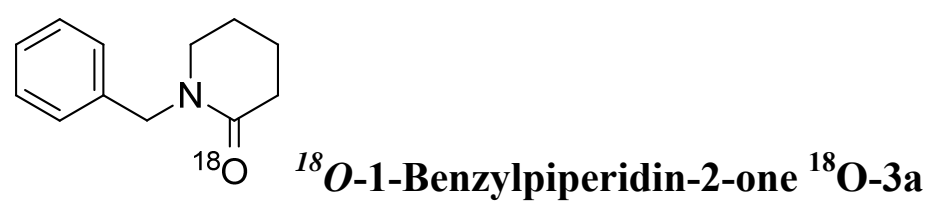

General procedure A was followed. Iodine $(190 \mathrm{mg}, 0.75 \mathrm{mmol})$ was added to a mixture of 1-benzylpiperidine $(18.5 \mu \mathrm{L}, 0.10 \mathrm{mmol})$ and sodium bicarbonate $(84 \mathrm{mg}, 1.00 \mathrm{mmol})$ in $\mathrm{THF} / \mathrm{H}_{2}{ }^{18} \mathrm{O}(2.9 / 1.1 \mathrm{~mL})$. Purification was carried out by silica gel chromatography using $30-85 \%$ TBME (with $1 \% 4 \mathrm{M}$ ammonia in methanol modifier)/cyclohexane as the eluent, to afford ${ }^{18} \mathrm{O}-3 \mathrm{a}(19.2 \mathrm{mg}, 100 \%)$ as a yellow oil.*

LCMS (High pH, UV, ESI) $\mathrm{R}_{\mathrm{t}}=0.86 \mathrm{~min},[\mathrm{M}+\mathrm{H}]^{+} 192.2$ (100\%), $190.2(3 \%)$

${ }^{1} \mathrm{H}$ NMR $\left(\mathrm{CDCl}_{3}, 400 \mathrm{MHz}\right): \delta$ 7.30-7.36 (m, 2H), 7.24-7.30 (m, 3H), $4.61(\mathrm{~s}, 2 \mathrm{H}), 3.21(\mathrm{t}$, $J=6.0 \mathrm{~Hz}, 2 \mathrm{H}), 2.48(\mathrm{t}, J=6.5 \mathrm{~Hz}, 2 \mathrm{H}), 1.73-1.85(\mathrm{~m}, 4 \mathrm{H})$

HRMS: Calculated for $\mathrm{C}_{12} \mathrm{H}_{16} \mathrm{~N}^{18} \mathrm{O} 192.1269$, found $[\mathrm{M}+\mathrm{H}]^{+}: 192.1266$ (-1.6 ppm).

${ }^{*}$ LCMS and ${ }^{1} \mathrm{H}$ NMR analysis showed presence of $7 \%$ of an iodinated lactam by-product, which could not be separated

Studies with sodium acetate: general procedure A was followed for all cases, although the reaction mixtures were not purified.

- with $\mathrm{NaOAc} / \mathrm{H}_{2} \mathrm{O}$

Iodine $(381 \mathrm{mg}, 1.50 \mathrm{mmol})$ was added to a mixture of 1-benzylpiperidine $(36.9 \mu \mathrm{L}, 0.20$ $\mathrm{mmol})$ and sodium acetate $(164 \mathrm{mg}, 2.00 \mathrm{mmol})$ in $\mathrm{THF} / \mathrm{H}_{2} \mathrm{O}(5.7 / 2.3 \mathrm{~mL})$.

LCMS (High pH, UV, ESI) $\mathrm{R}_{\mathrm{t}}=0.86 \min (\mathbf{3 a}),[\mathrm{M}+\mathrm{H}]^{+} 190.1$ (100\%).

- with $\mathrm{Na}^{18} \mathrm{OAc} / \mathrm{H}_{2} \mathrm{O}$

Iodine (381 $\mathrm{mg}, 1.50 \mathrm{mmol})$ was added to a mixture of 1-benzylpiperidine $(36.9 \mu \mathrm{L}, 0.20$ $\mathrm{mmol})$ and sodium acetate $(164 \mathrm{mg}, 2.00 \mathrm{mmol})$ in $\mathrm{THF} / \mathrm{H}_{2} \mathrm{O}(5.7 / 2.3 \mathrm{~mL})$. 
LCMS (High pH, UV, ESI) $\mathrm{R}_{\mathrm{t}}=0.85 \min (\mathbf{3 a}),[\mathrm{M}+\mathrm{H}]^{+} 190.1$ (100\%).

- with $\mathrm{Na}^{18} \mathrm{OAc} / \mathrm{H}_{2}{ }^{18} \mathrm{O}$

Iodine (381 mg, $1.50 \mathrm{mmol})$ was added to a mixture of 1-benzylpiperidine $(36.9 \mu \mathrm{L}, 0.20$ $\mathrm{mmol})$ and sodium acetate $(164 \mathrm{mg}, 2.00 \mathrm{mmol})$ in $\mathrm{THF} / \mathrm{H}_{2} \mathrm{O}(5.7 / 2.3 \mathrm{~mL})$.

LCMS (High pH, UV, ESI) $\mathrm{R}_{\mathrm{t}}=0.86 \min (\mathbf{3 a}),[\mathrm{M}+\mathrm{H}]^{+} 192.1(100 \%)$. 


\section{$\underline{\text { Investigating late-stage oxidation under Milstein conditions }}^{[11]}$}

Stock solutions of Acridine $\mathrm{Ru}$ complex $1(6 \mathrm{mg}, 0.01 \mathrm{mmol})$ in 1,4-dioxane $(1.5 \mathrm{~mL})$ and $\mathrm{NaOH}(40 \mathrm{mg}, 1.01 \mathrm{mmol})$ in water $(1.5 \mathrm{~mL})$ were prepared. 1.0 extra equivalent of $\mathrm{NaOH}$ was added compared to the literature conditions in order to neutralize the $\mathrm{HCl}$ salt of the drug substrates. A $0.15 \mathrm{~mL}$ aliquot of the catalyst solution and a $0.15 \mathrm{~mL}$ aliquot of the $\mathrm{NaOH}$ solution were added to either melperone hydrochloride $(30 \mathrm{mg}, 0.10 \mathrm{mmol})$ or bepridil hydrochloride hydrate $(42 \mathrm{mg}, 0.10 \mathrm{mmol})$. The reaction mixture was heated to $150{ }^{\circ} \mathrm{C}$ for $48 \mathrm{~h}$. The reaction mixture was then allowed to cool to room temperature, before diluting in water $(1 \mathrm{~mL})$ and extracting into DCM $(2 \times 1.5 \mathrm{~mL})$. The crude solution was concentrated under flow of nitrogen, and the crude material was redissolved in $\mathrm{CDCl}_{3}$ and analyzed by ${ }^{1} \mathrm{H}$ NMR.

${ }^{1} \mathrm{H}$ NMR analysis of the crude materials showed:

- $4 \%$ conversion to $\mathbf{5 h}$ and $93 \%$ remaining starting material based on peaks at $3.40 \mathrm{ppm}$ and $7.10 \mathrm{ppm}$, respectively, against 3,4,5-trichloropyridine $(0.086 \mathrm{mmol})$ as a standard;

- $8 \%$ conversion to $\mathbf{5 i}$ and $91 \%$ remaining starting material based on peaks at $2.24 \mathrm{ppm}$ and $6.79 \mathrm{ppm}$, respectively, against $3,4,5$-trichloropyridine $(0.119 \mathrm{mmol})$ as a standard.

\section{$\underline{\text { Investigating late-stage oxidation under Emmert conditions }}^{[12]}$}

A stock solution of $\mathrm{FeCl}_{3} .6 \mathrm{H}_{2} \mathrm{O}(14 \mathrm{mg}, 0.05 \mathrm{mmol})$ in pyridine $(3.60 \mathrm{~mL})$ was prepared. A $0.36 \mathrm{~mL}$ aliquot of this solution was added to a mixture of 2-picolinic acid (0.6 $\mathrm{mg}, 5.0$ $\mu \mathrm{mol})$, tert-butyl benzoperoxoate $(57.0 \mu \mathrm{L}, 0.30 \mathrm{mmol})$, water $(16.2 \mu \mathrm{L}, 0.90 \mathrm{mmol})$, and either melperone hydrochloride $(30 \mathrm{mg}, 0.10 \mathrm{mmol})$ or bepridil hydrochloride hydrate (42 $\mathrm{mg}, 0.10 \mathrm{mmol}$ ), and the reaction mixture was stirred at $50{ }^{\circ} \mathrm{C}$ for $24 \mathrm{~h}$. The solvent was removed and the crude residue was redissolved in $\mathrm{CDCl}_{3}$ and analyzed by ${ }^{1} \mathrm{H} \mathrm{NMR}$.

${ }^{1} \mathrm{H}$ NMR analysis of the crude materials showed:

- $0 \%$ conversion to $\mathbf{5 h}$ against 3,4,5-trichloropyridine $(0.056 \mathrm{mmol})$ as a standard;

- $0 \%$ conversion to $\mathbf{5 i}$ against 3,4,5-trichloropyridine $(0.094 \mathrm{mmol})$ as a standard.

\section{$\underline{\text { Investigating late-stage oxidation under classical RuIVO2/NaIO4 conditions }}^{[13]}$}

Either melperone hydrochloride $(30 \mathrm{mg}, 0.10 \mathrm{mmol}$ ) or bepridil hydrochloride hydrate (42 $\mathrm{mg}, 0.10 \mathrm{mmol})$ was added to a mixture of ruthenium(IV) oxide $(1.3 \mathrm{mg}, 10.0 \mu \mathrm{mol})$ and sodium periodate $(135.0 \mathrm{mg}, 0.63 \mathrm{mmol})$ in ethyl acetate $(0.24 \mathrm{~mL})$ and water $(0.94 \mathrm{~mL})$, and the reaction mixture was stirred at RT for $64 \mathrm{~h}$. The reaction mixture was diluted with water $(10 \mathrm{~mL})$ and extracted into EtOAc $(3 \times 10 \mathrm{~mL})$. The combined organic layers were passed through a hydrophobic frit, and concentrated in vacuo. The crude residue was redissolved in $\mathrm{CDCl}_{3}$ and analyzed by ${ }^{1} \mathrm{H} \mathrm{NMR}$. 
${ }^{1} \mathrm{H}$ NMR analysis of the crude materials showed:

- $0 \%$ conversion to $\mathbf{5 h}$ against 3,4,5-trichloropyridine $(0.094 \mathrm{mmol})$ as a standard;

- $0 \%$ conversion to $\mathbf{5 i}$ against 3,4,5-trichloropyridine $(0.066 \mathrm{mmol})$ as a standard.

\section{$\underline{\text { Investigating late-stage oxidation under hypervalent iodine conditions }}^{[14]}$}

Either melperone hydrochloride $(30 \mathrm{mg}, 0.10 \mathrm{mmol}$ ) or bepridil hydrochloride hydrate (42 $\mathrm{mg}, 0.10 \mathrm{mmol})$ was added to a solution of iodobenzene diacetate $(71 \mathrm{mg}, 0.22 \mathrm{mmol})$ in THF $(0.36 \mathrm{~mL})$. Water $(0.14 \mathrm{~mL})$ was added, and the reaction mixture stirred at RT for $16 \mathrm{~h}$. The solvent was evaporated under flow of nitrogen and the crude residue was redissolved in $\mathrm{CDCl}_{3}$ and analyzed by $1 \mathrm{H} \mathrm{NMR}$.

${ }^{1} \mathrm{H}$ NMR analysis of the crude materials showed:

- $0 \%$ conversion to $\mathbf{5 h}$ against 3,4,5-trichloropyridine $(0.067 \mathrm{mmol})$ as a standard;

- $0 \%$ conversion to $\mathbf{5 i}$ against 3,4,5-trichloropyridine $(0.080 \mathrm{mmol})$ as a standard.

Water was used as a co-solvent in order to try to form phenyliodosobenzene ${ }^{[15]}$ as the oxidant in situ. Comparitive reactions were also carried out using DCM as the solvent, as was used in the route described by Waghmode, ${ }^{[14]}$ and also in anhydrous THF to ascertain if the presence of water was inhibiting the oxidation, but the reaction profiles were same as with the $\mathrm{THF} / \mathrm{H}_{2} \mathrm{O}$ system. 
NMR Spectra of synthesized compounds

Crude ${ }^{1}$ H NMR spectra of selected entries during optimization and mechanistic studies

Table S1, entry 7

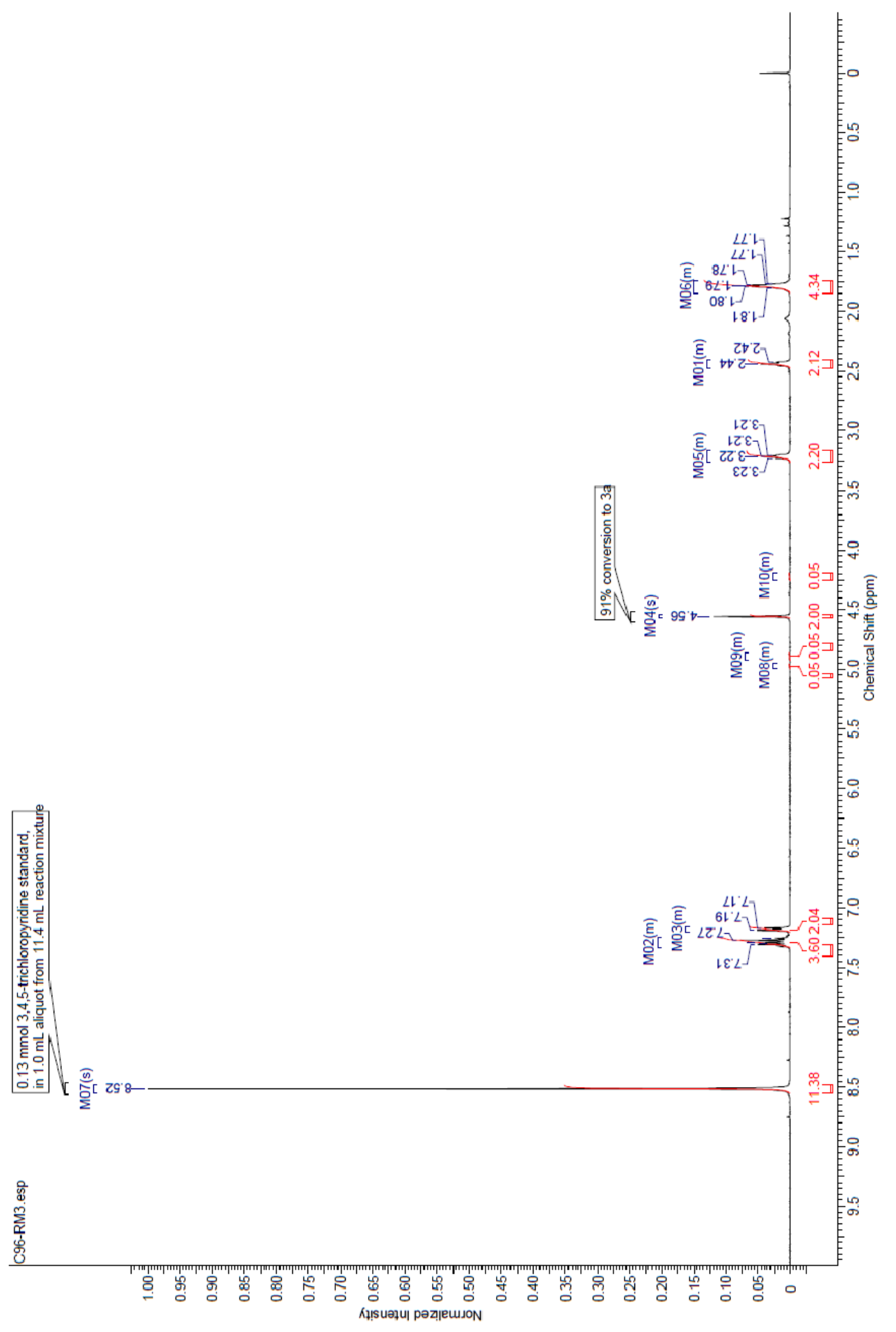


Table S1, entry 8

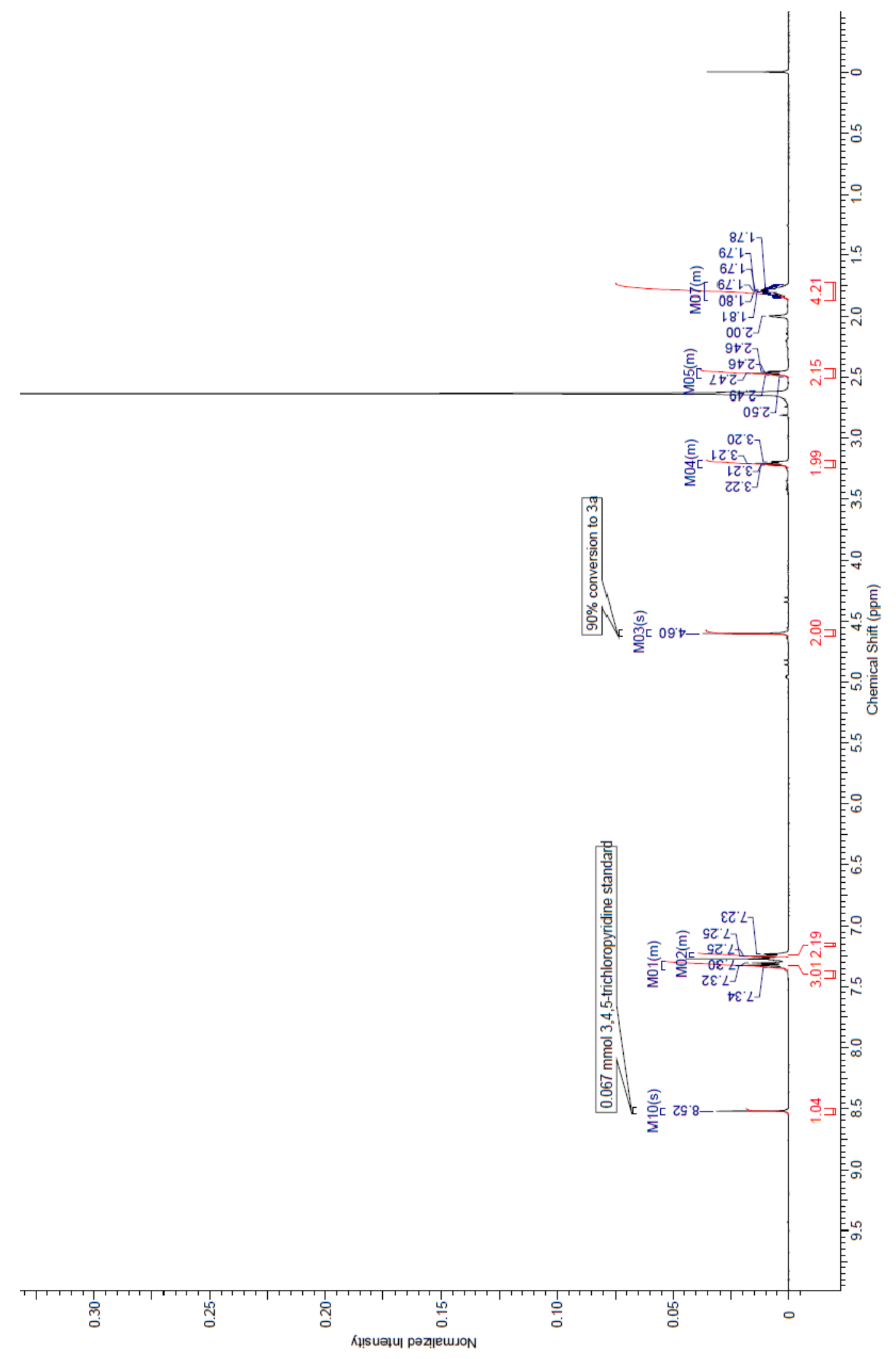


Table S1, entry 10

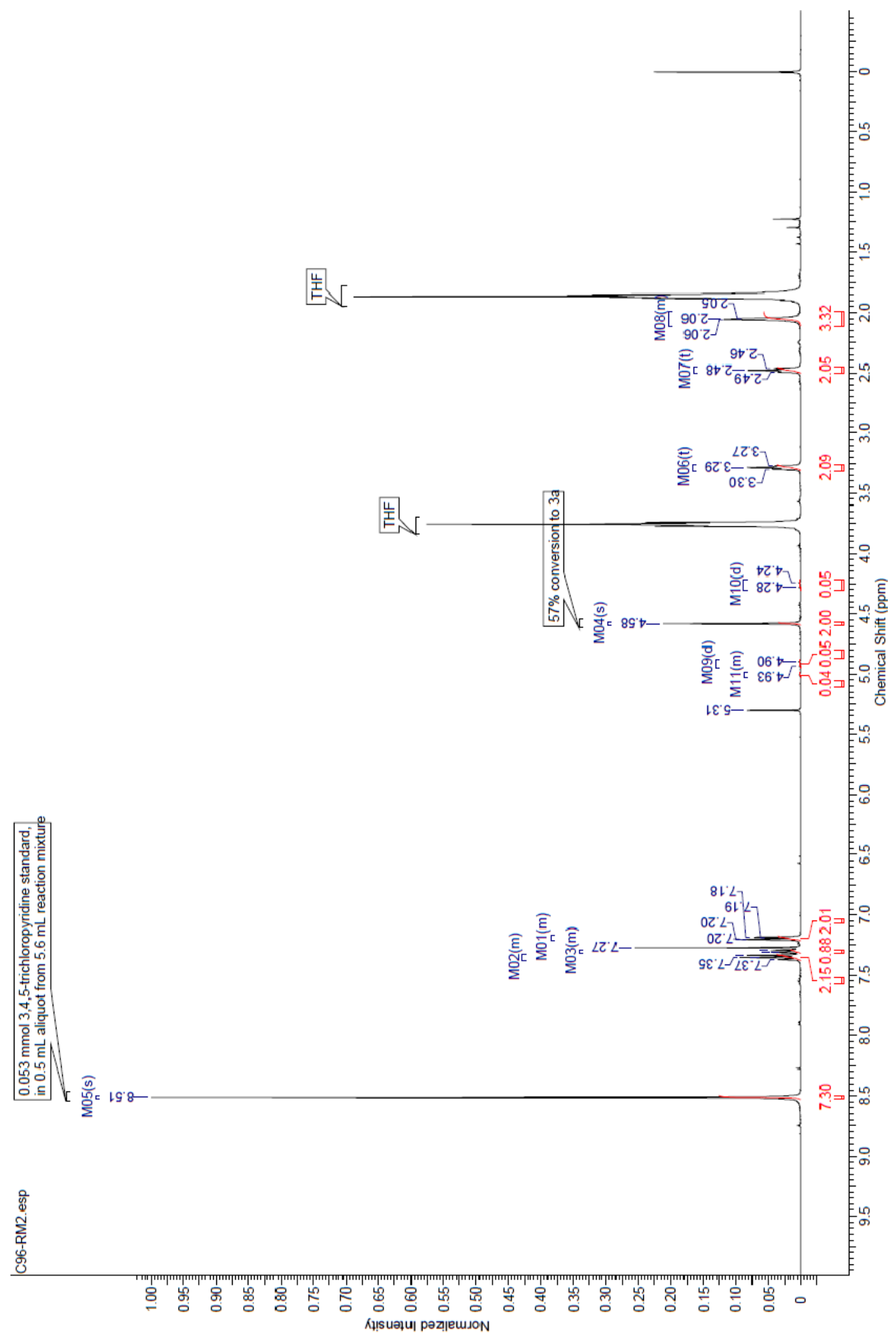


Table S1, entry 10

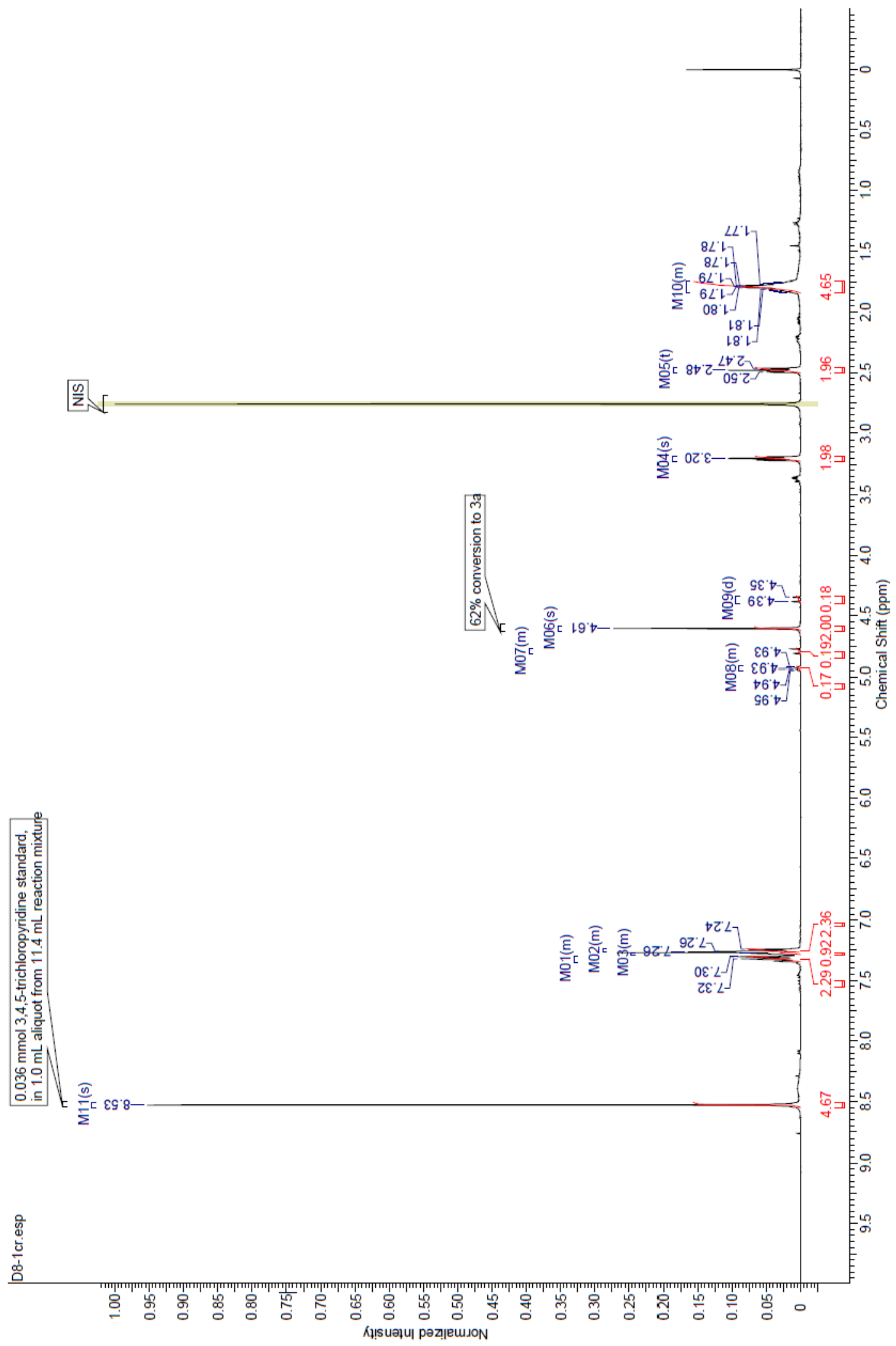


Table S2, entry 1

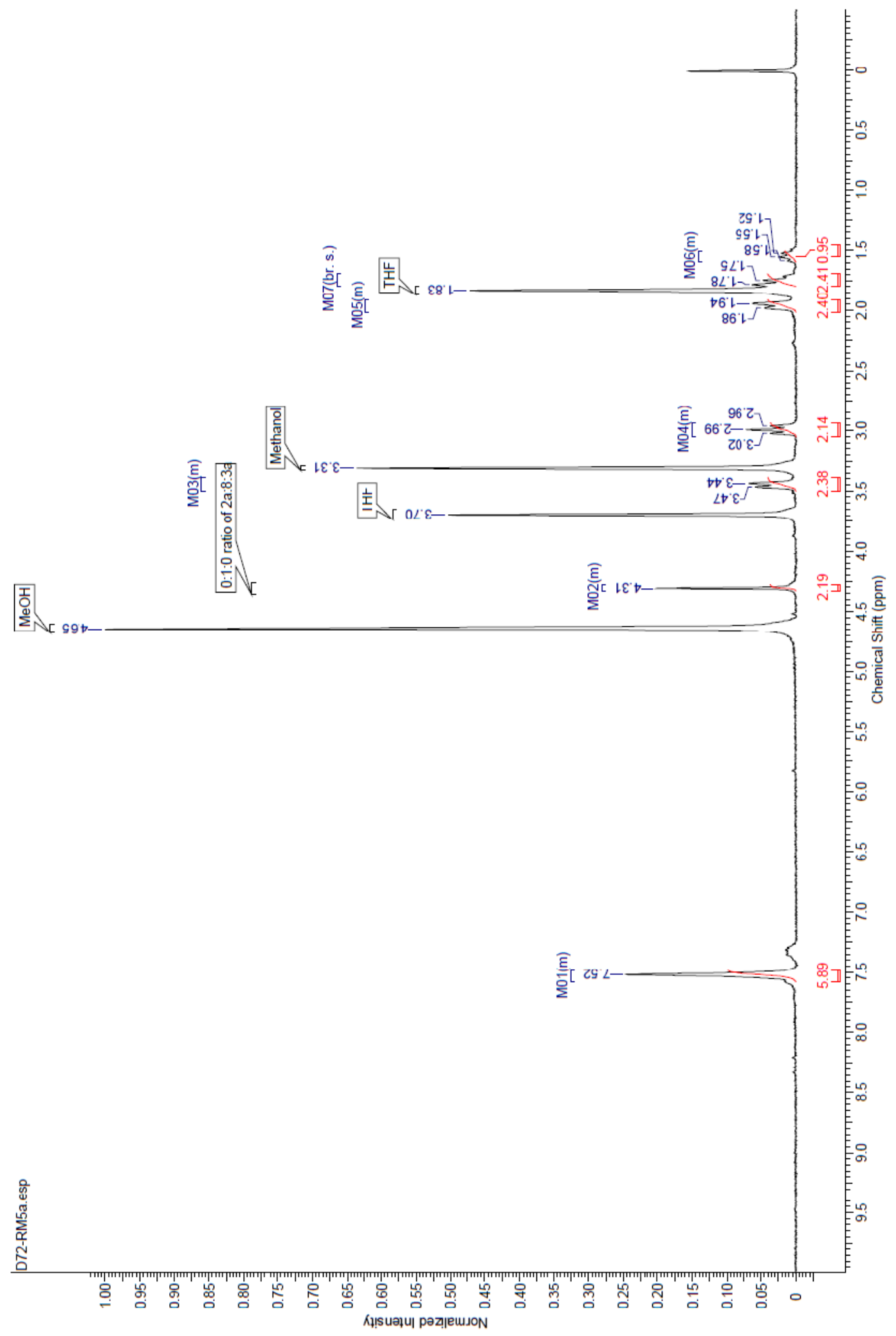


Table S2, entry 2

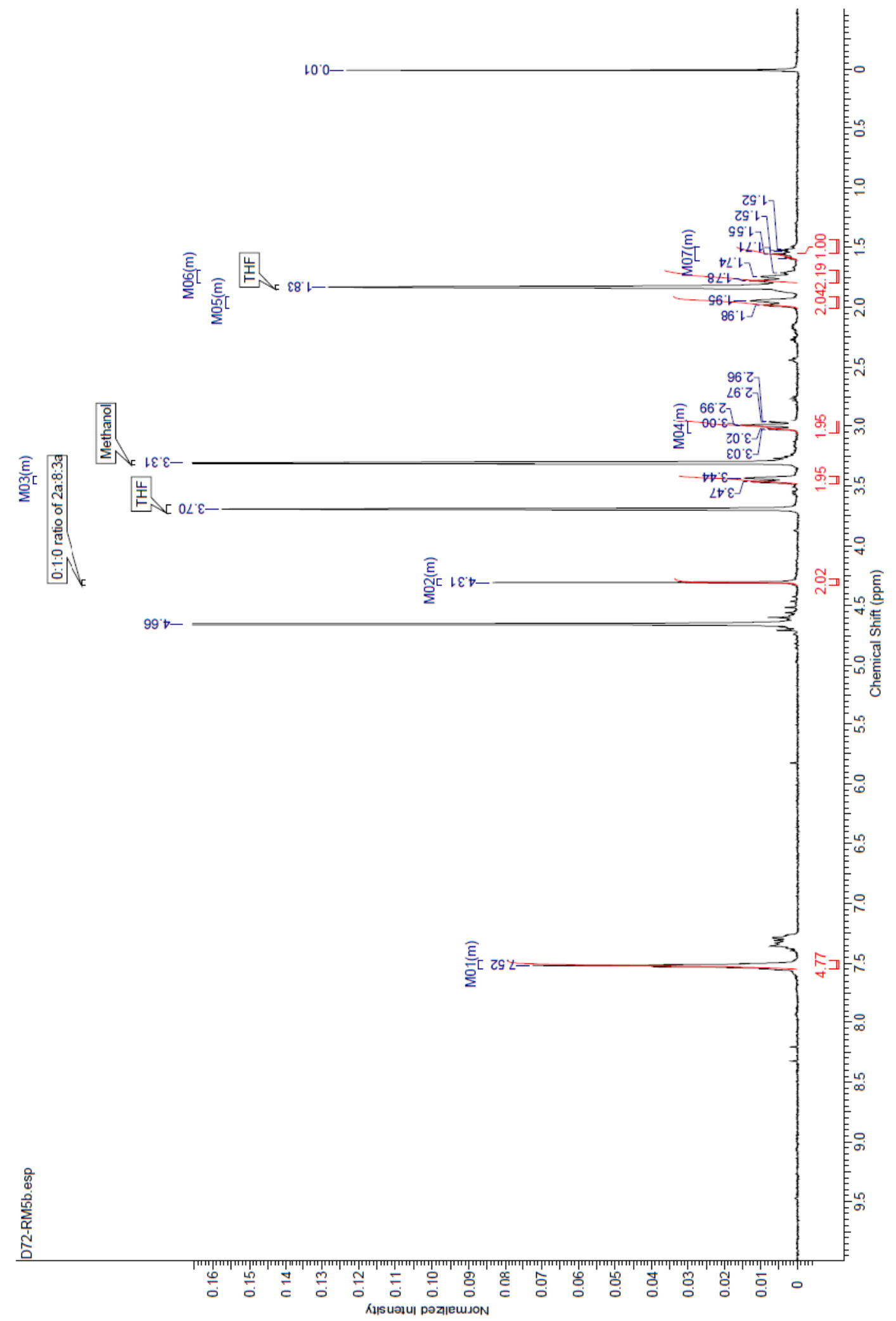


Table S2, entry 3

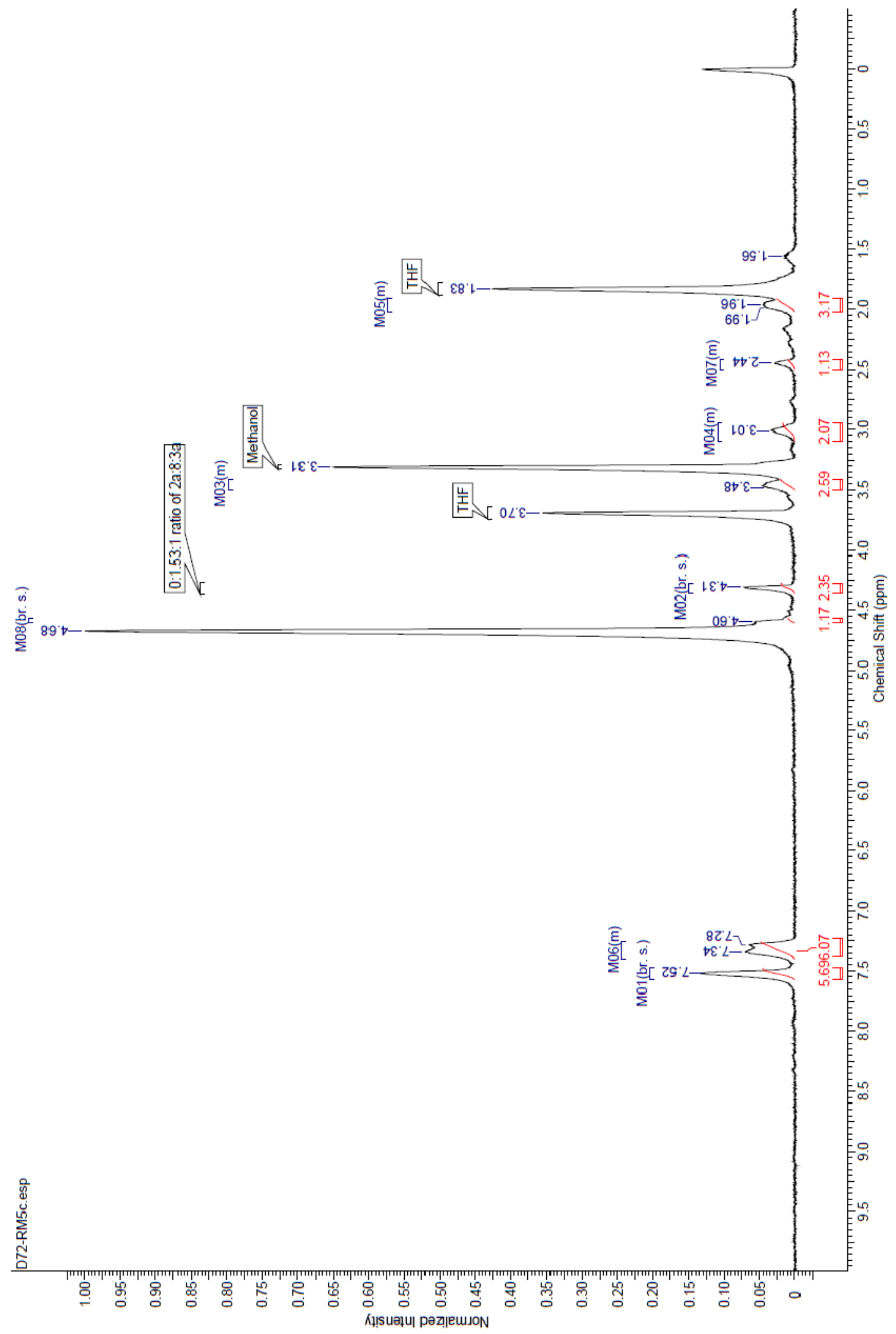


Table S2, entry 4

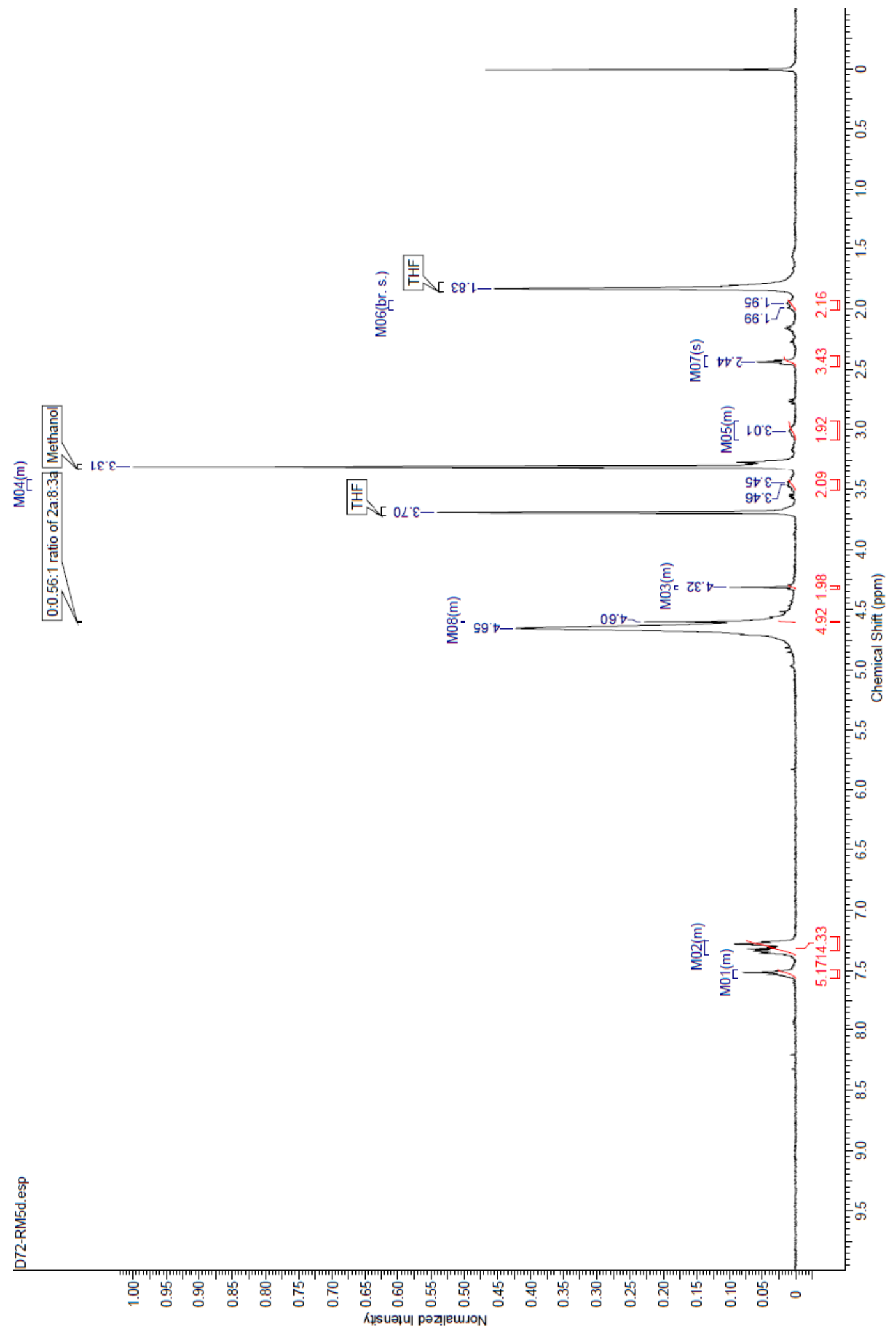


Table S2, entry 5

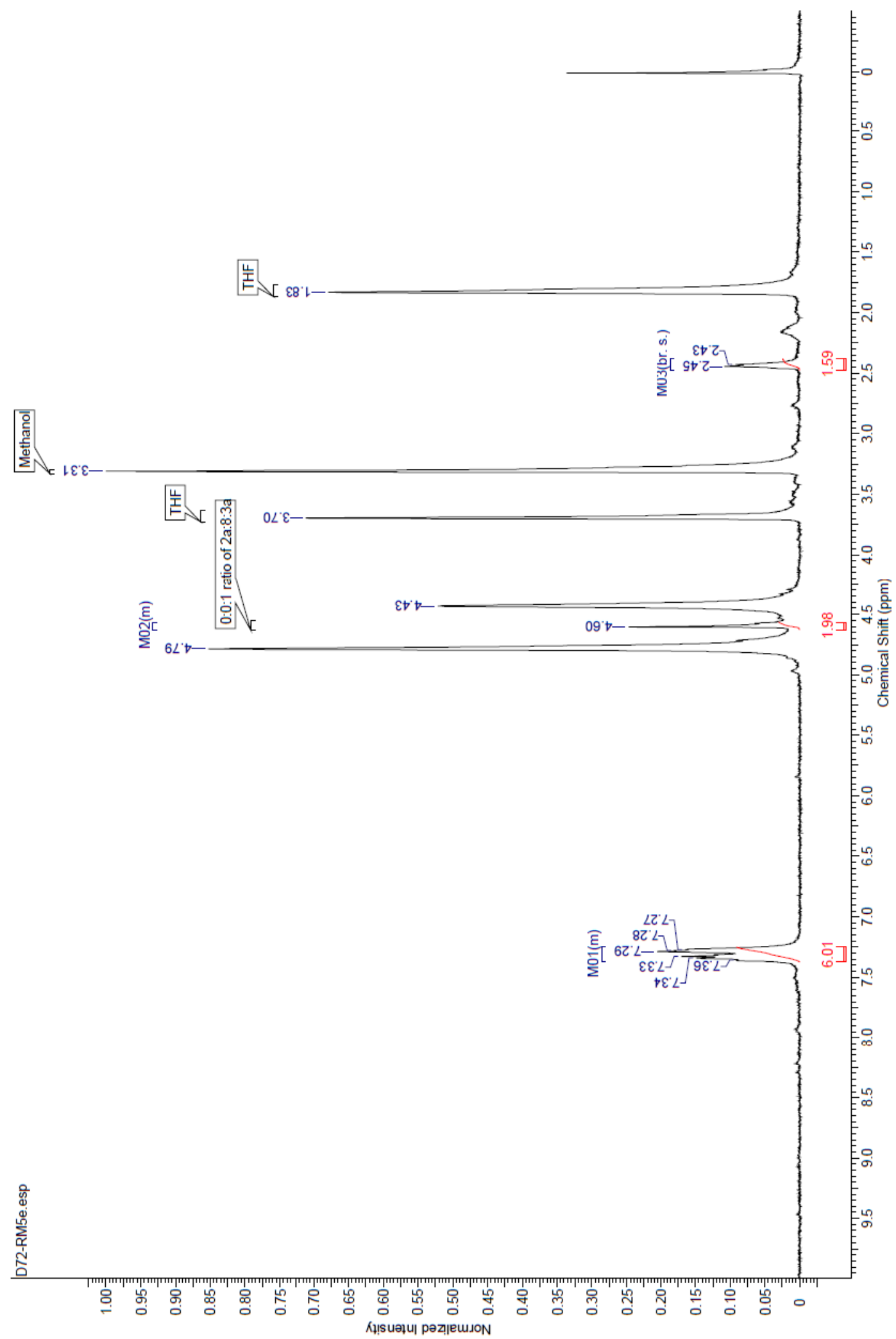


Table S2, entry 6

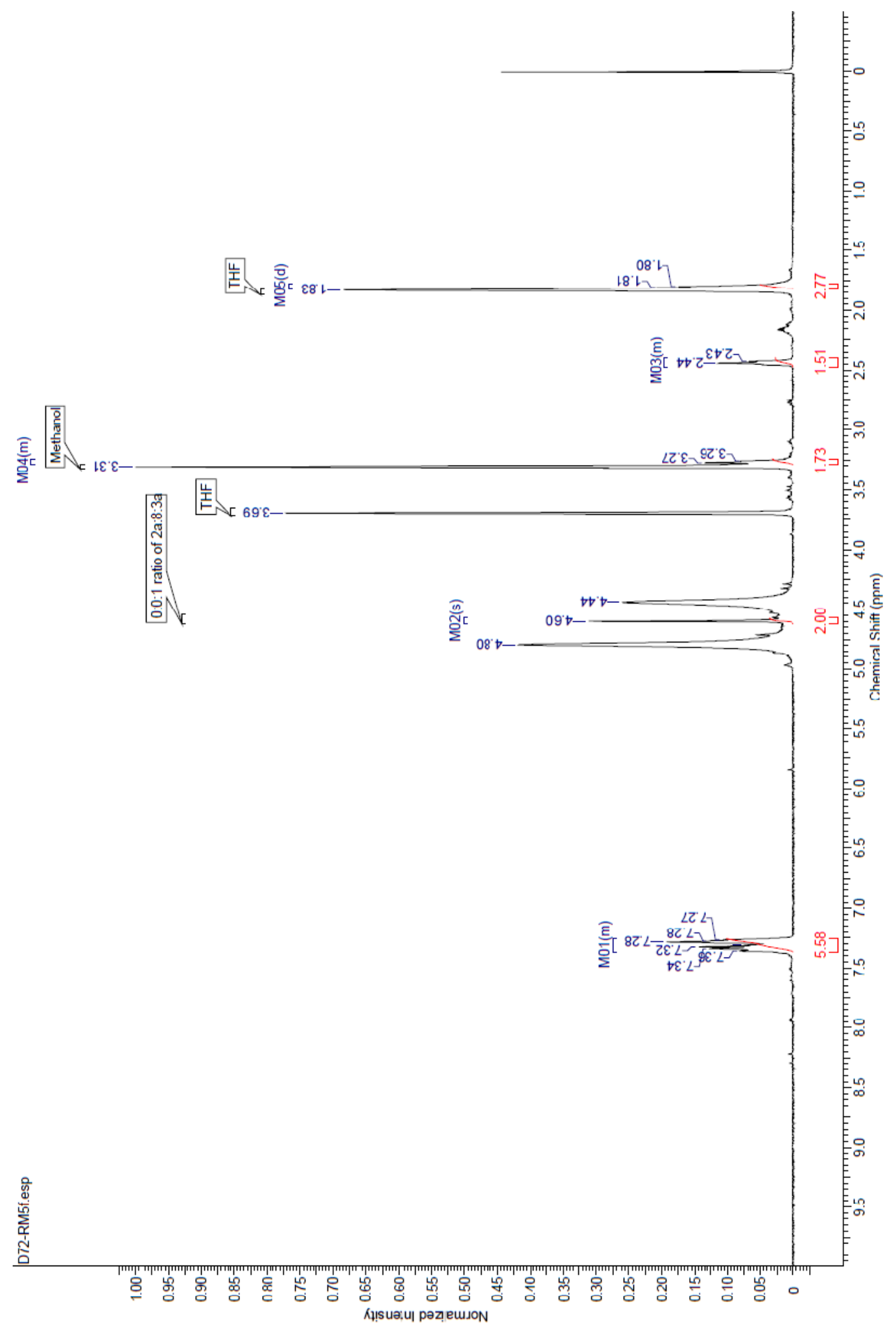


Table S2, entry 7

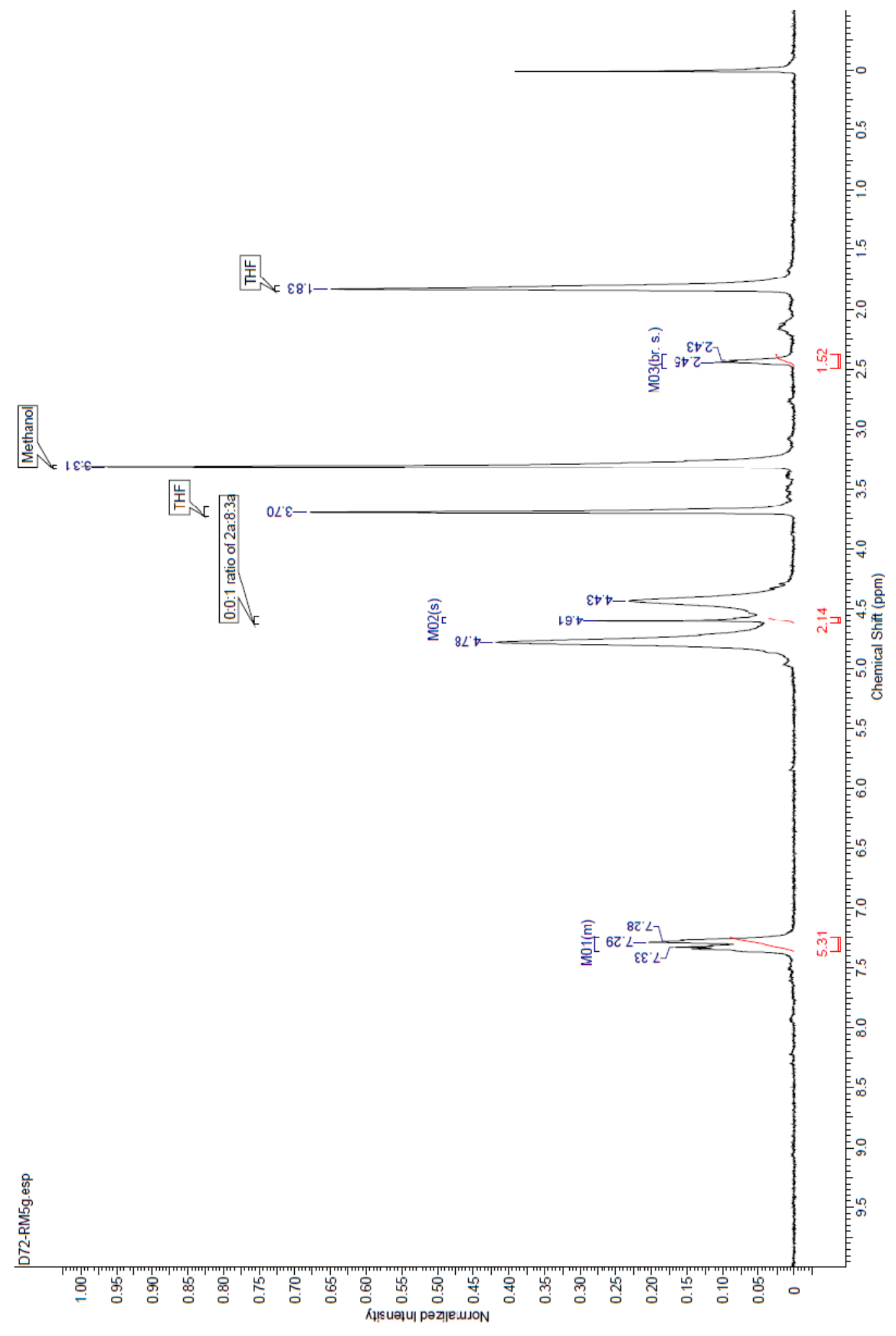


${ }^{1}$ H NMR spectra of selected crude substrates determining NMR conversions NBoc

Tert-butyl 4-benzyl-3-oxopiperazine-1-carboxylate $3 \mathrm{~h}$

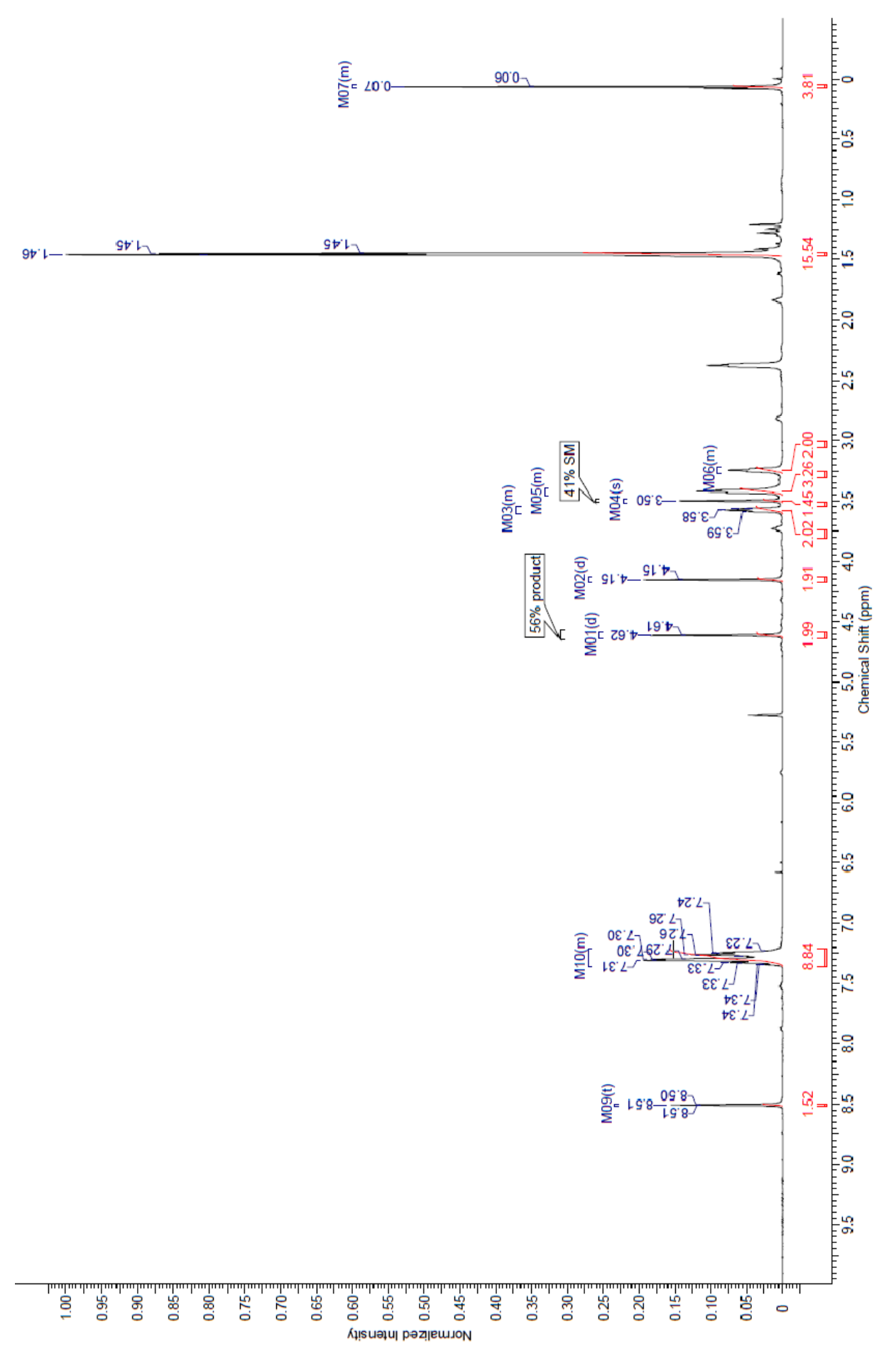


4-Benzyl-1-methylpiperazin-2-one 3i

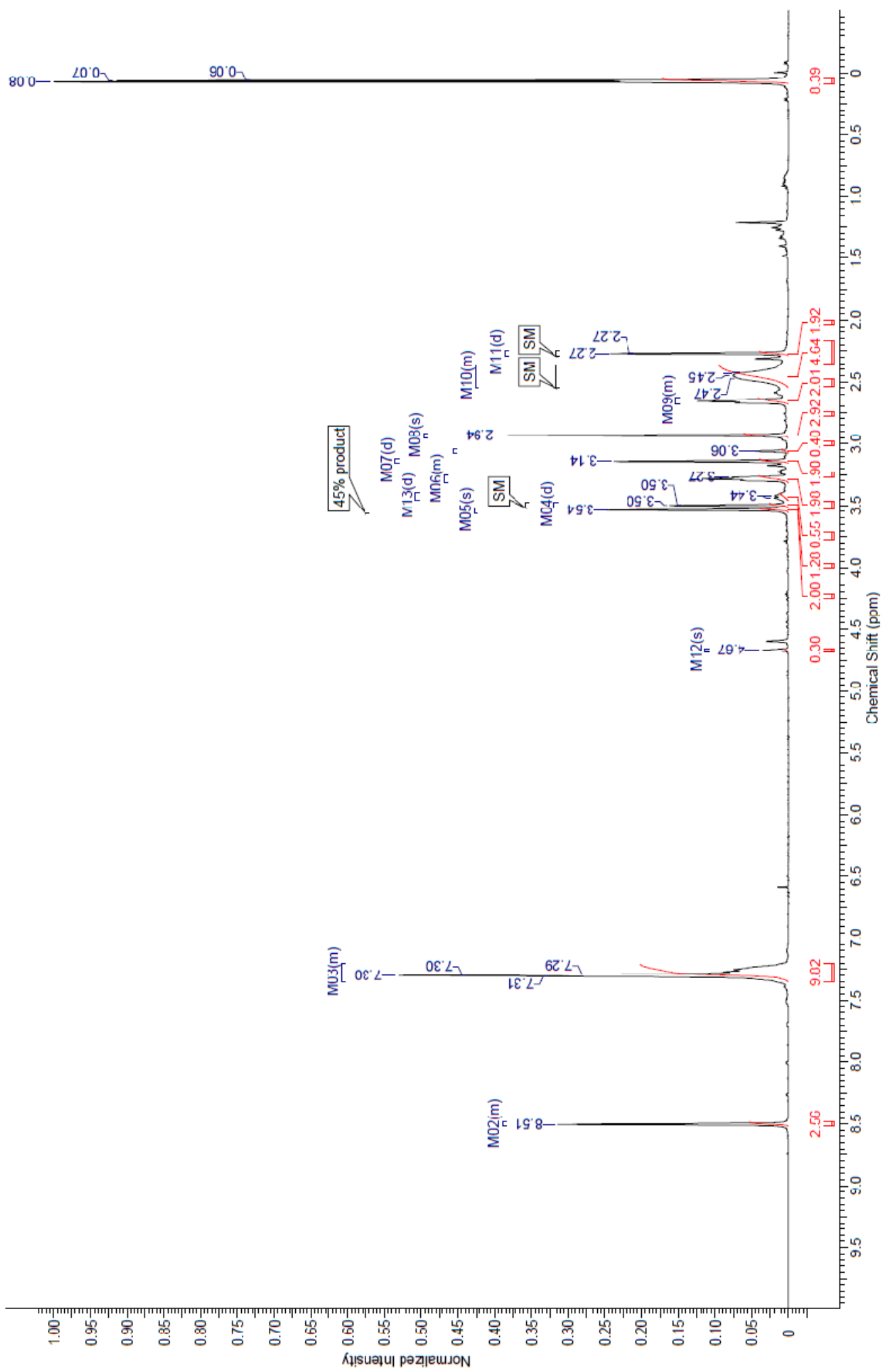


<smiles>O=C1CC(c2ccccc2)CCN1</smiles>

4-Phenylpiperidin-2-one 31

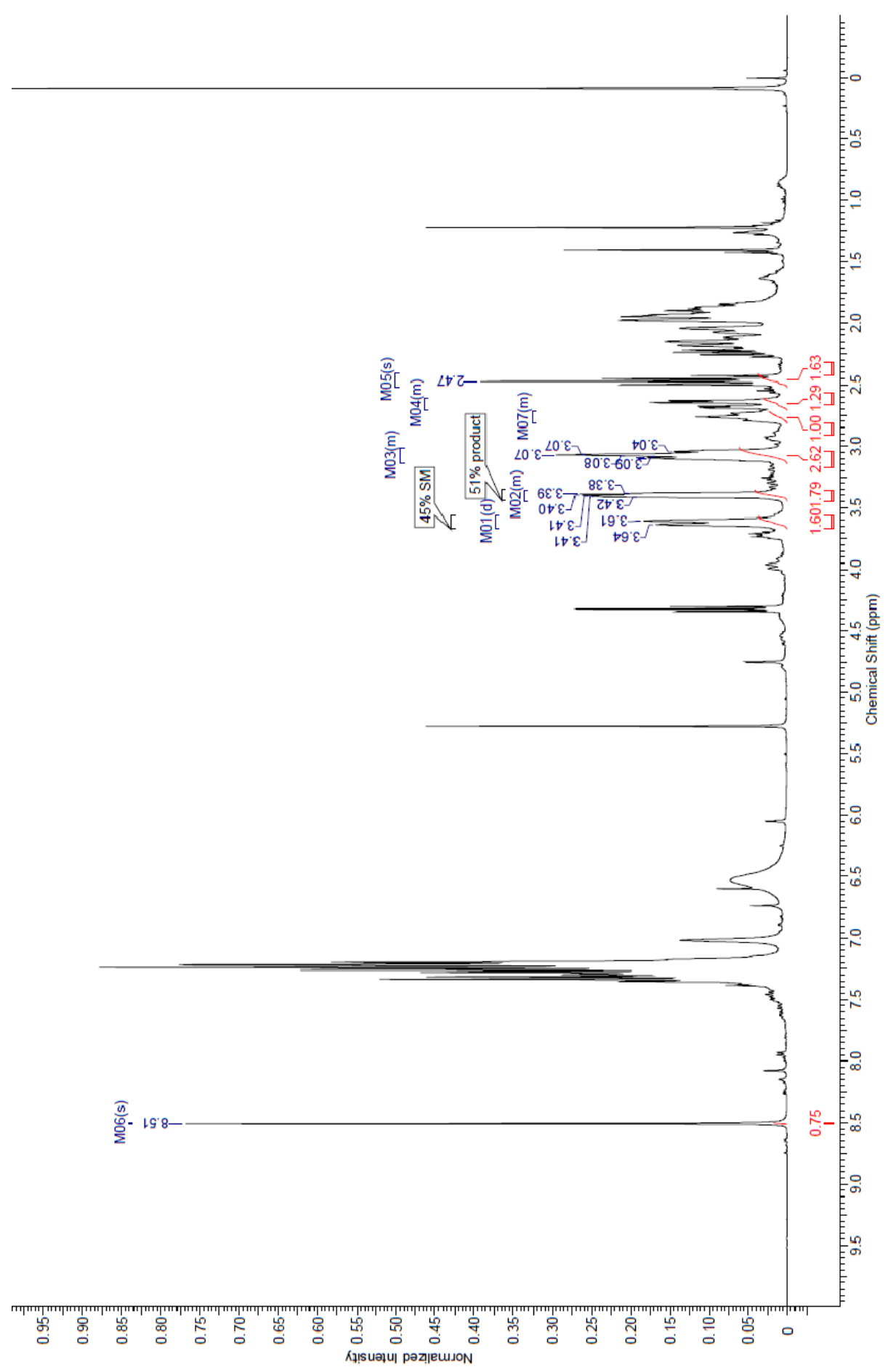


Oxo-acrivastine 5d

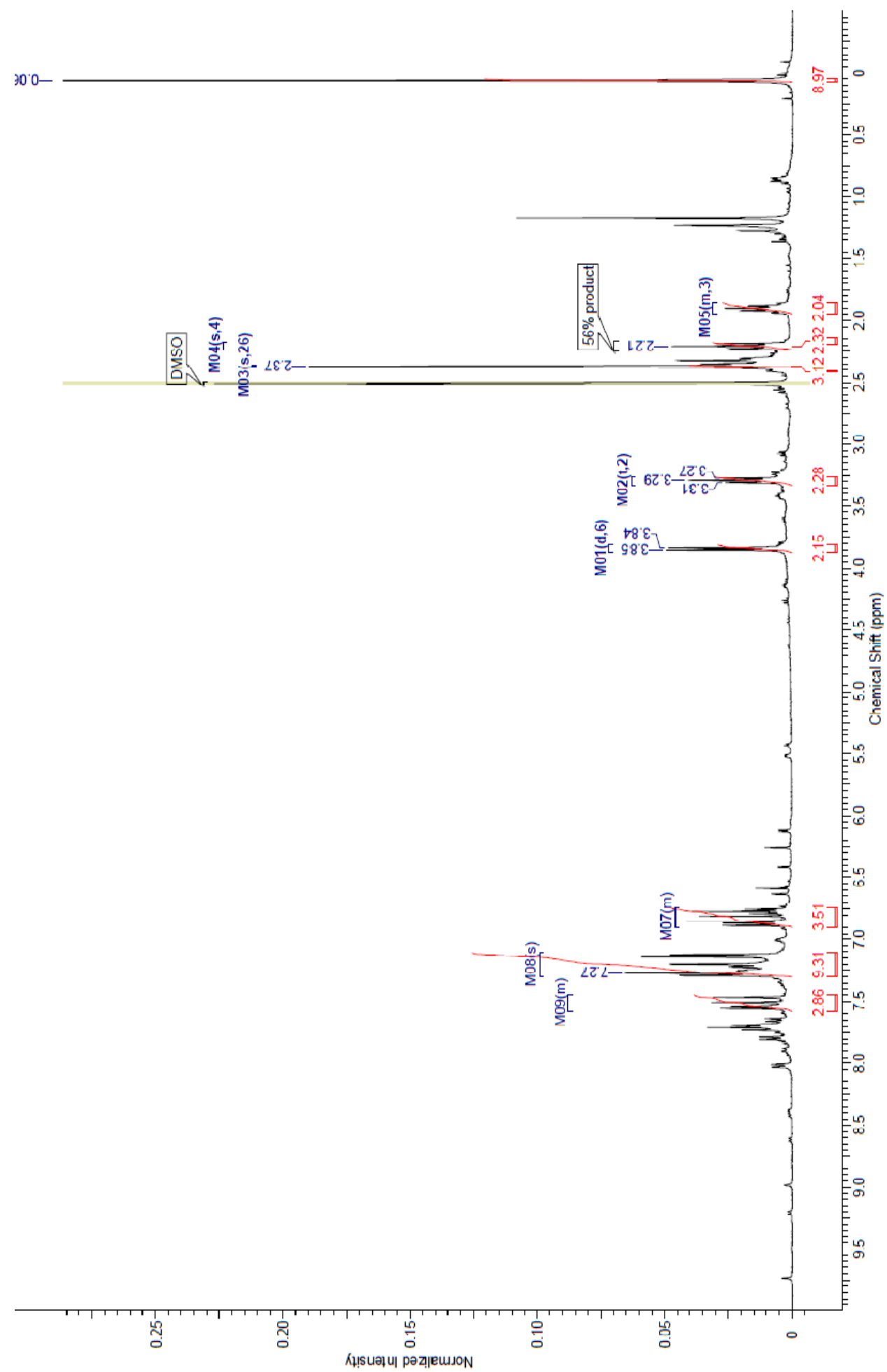


<smiles>CCCc1nc(C)c2c(=O)[nH]c(-c3cc(S(=O)(=O)N4CCN(CC)C(=O)C4)ccc3OCC)nn12</smiles>

Oxo-vardenafil 5e

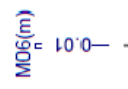

商- $\angle S ' z-$

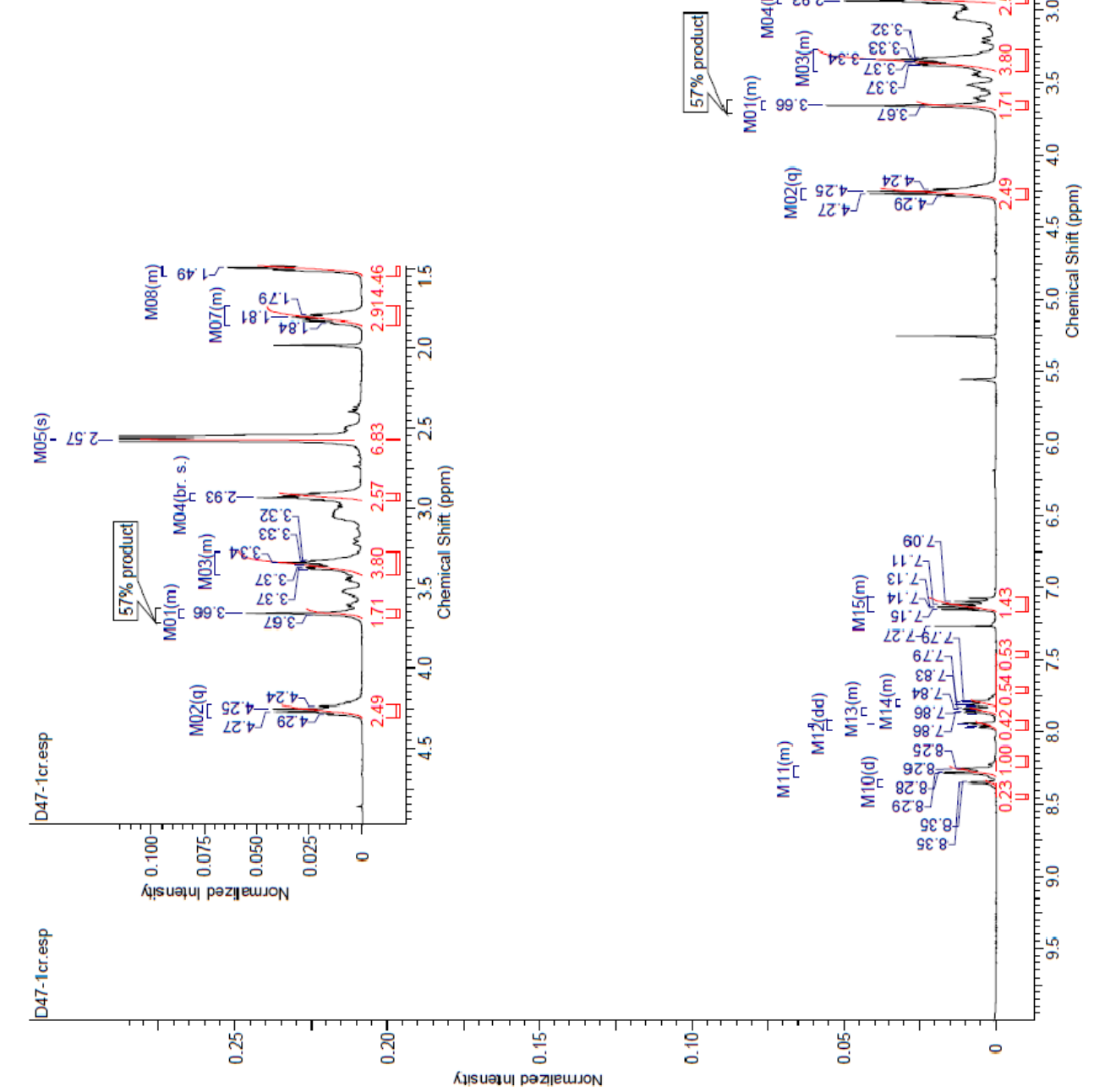

क्षे 26
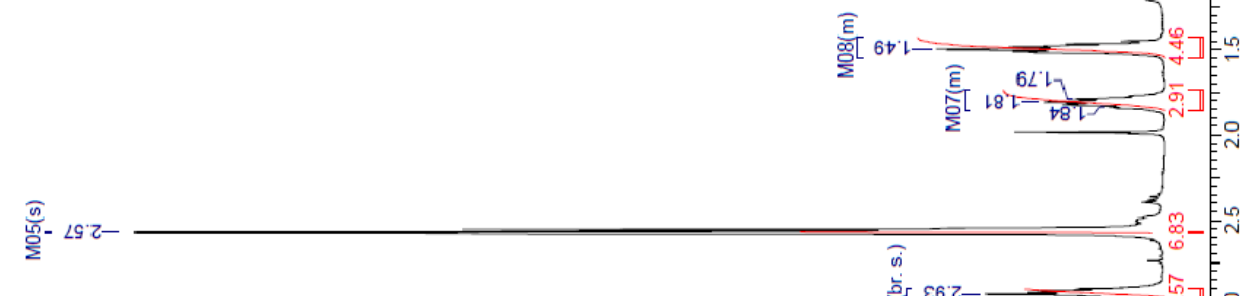
<smiles>CN1CCC(n2nc(Cc3ccc(Cl)cc3)c3ccccc3c2=O)CCC1=O</smiles><smiles>CN1CCCC(n2nc(Cc3ccc(Cl)cc3)c3ccccc3c2=O)CC1=O</smiles>

4.3:1 ratio of a mixture of co-eluting 7-Oxo-azelastine $5 \mathrm{~g}^{\alpha}$ and 2 -oxo-azelastine $5 \mathrm{~g}^{\beta}$

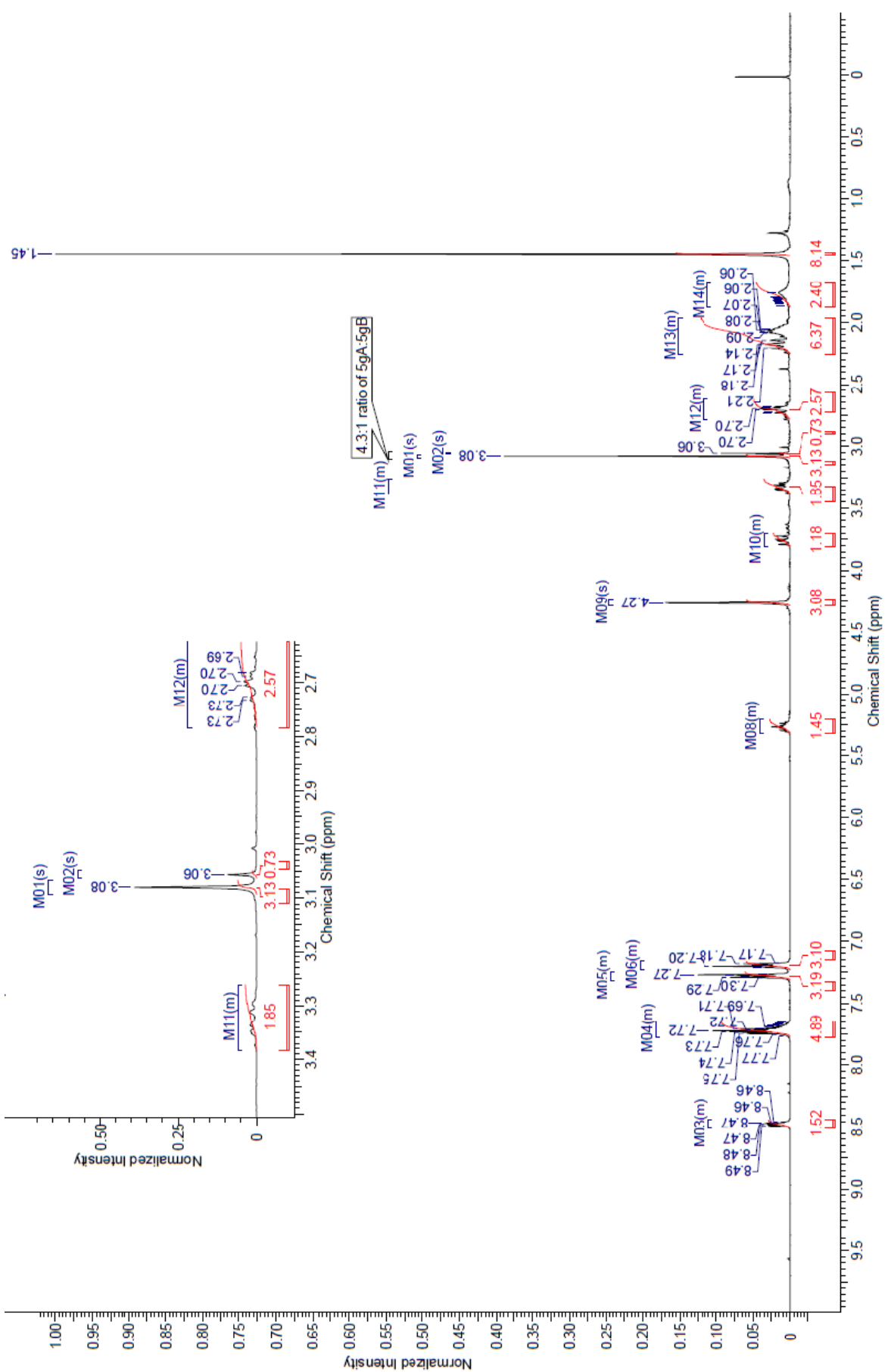


<smiles>CC(C)COCC(CN(Cc1ccccc1)c1ccccc1)N1CCCC1=O</smiles><smiles>CC(C)COCC(CN(Cc1ccccc1)c1ccc(I)cc1)N1CCCC1=O</smiles>

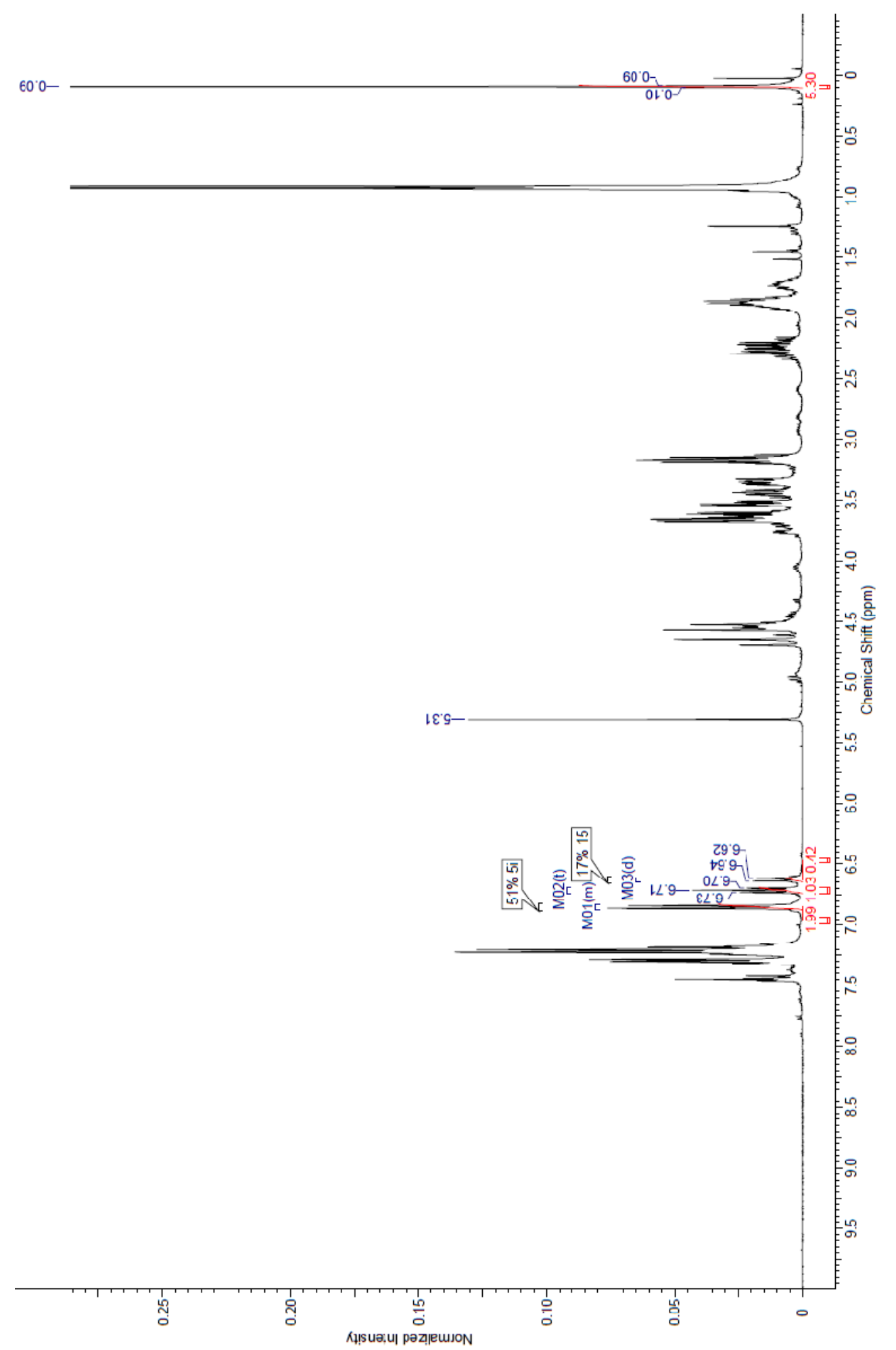


<smiles>CNS(=O)(=O)CCc1ccc2c(c1)C1(CCC23CC3)CCC1(F)F</smiles>

[bicyclo[2.2.1] heptane-7,3'-indolin]-1-ium iodide 14

1-Methyl-5'-(2-( $N$-methylsulfamoyl)ethyl)-2'-oxo-1-azaspiro

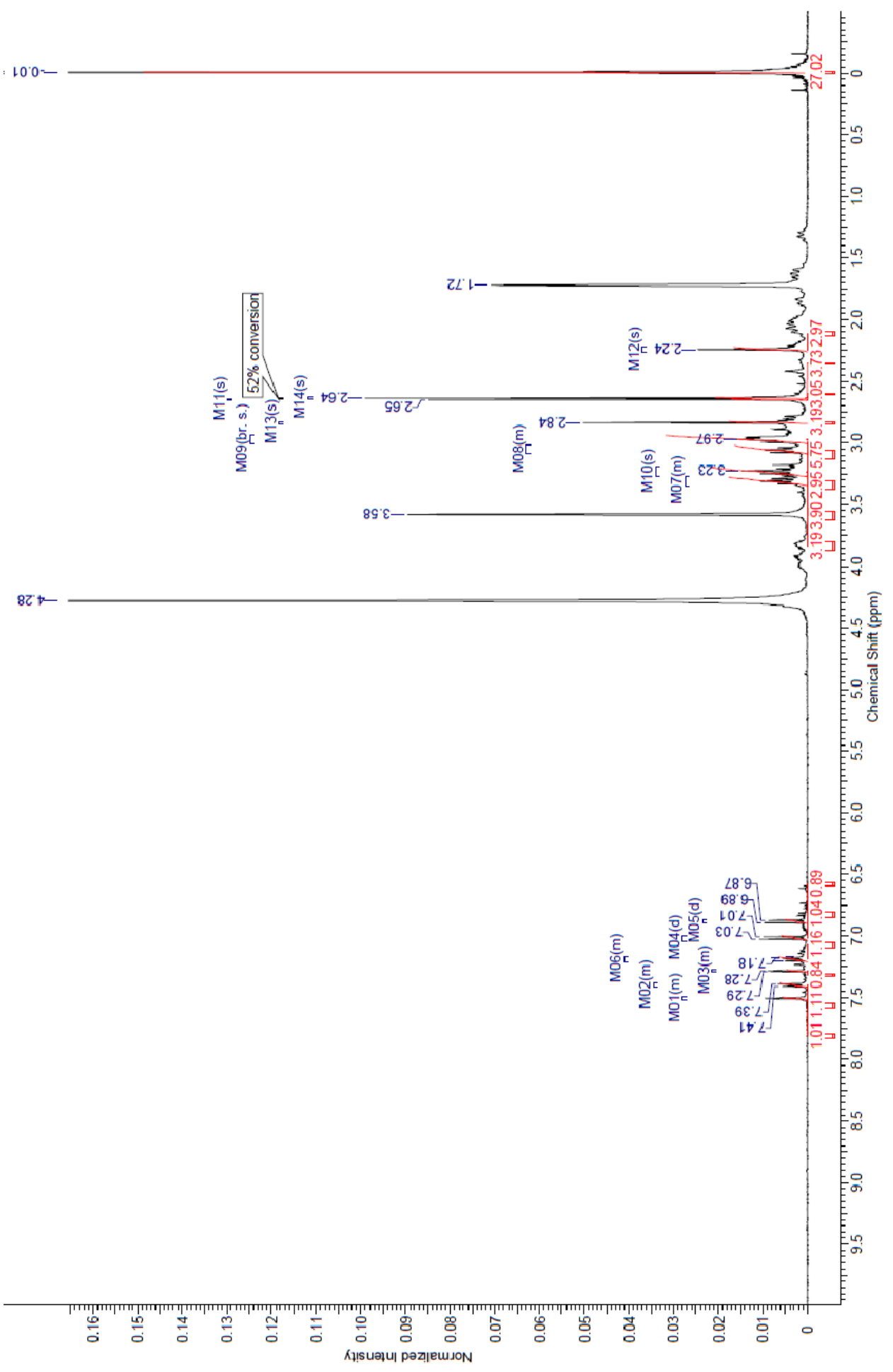




\section{Isolated compounds}

1-(4-Methoxybenzyl)piperidine 2b

${ }^{1}$ H NMR

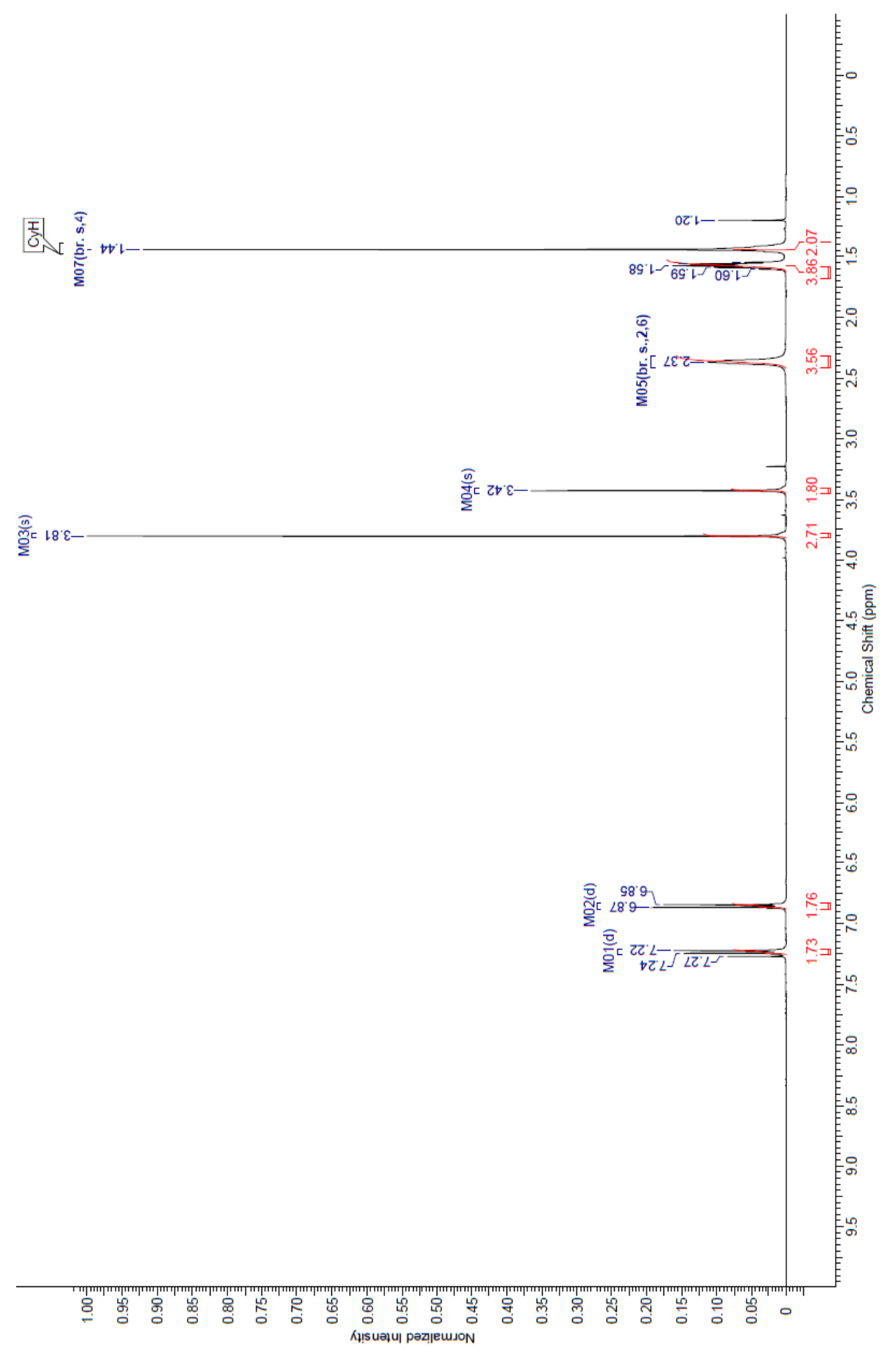


1-(4-Nitrobenzyl)piperidine 2c

\section{${ }^{1}$ H NMR}

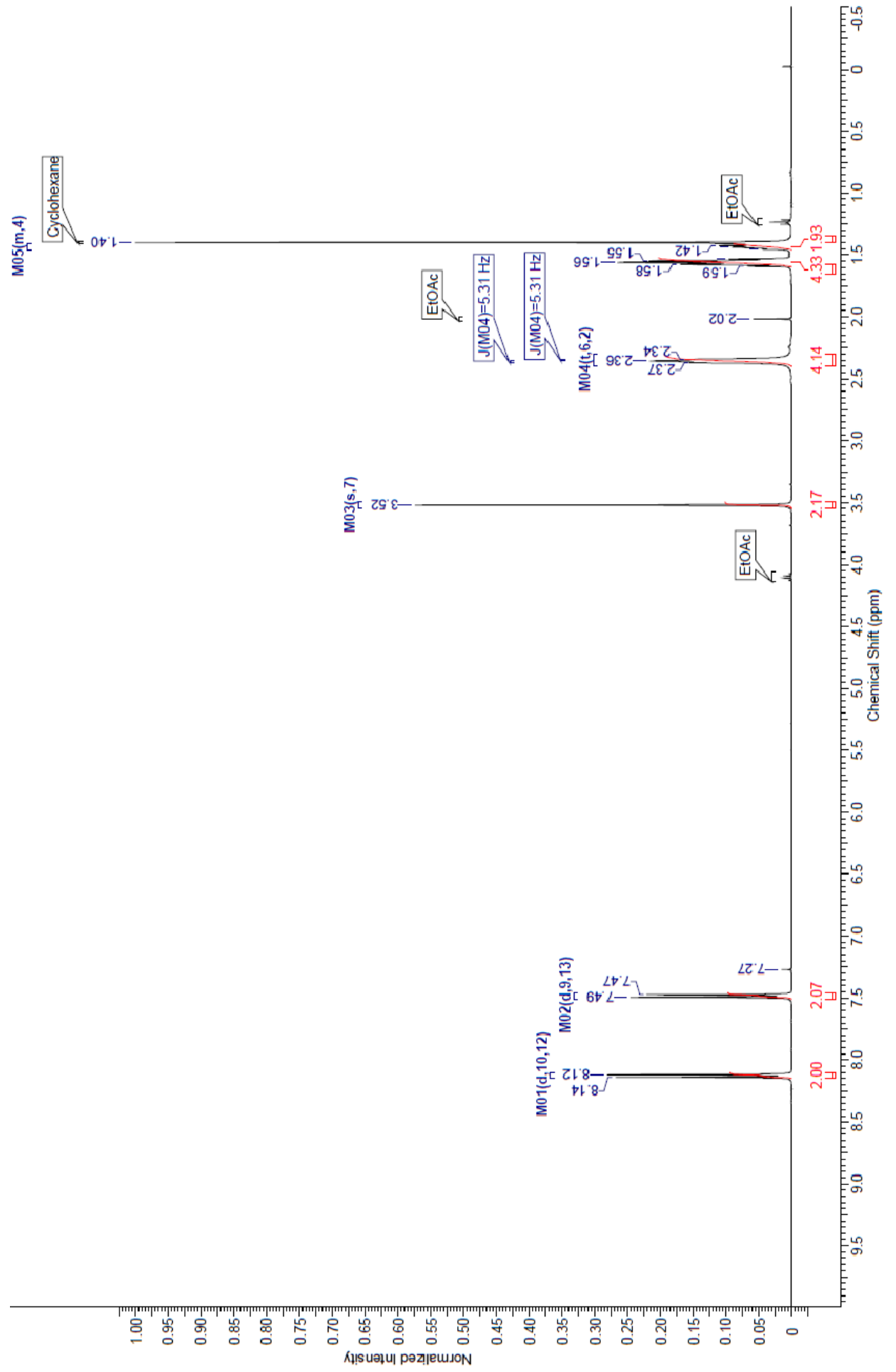


2-Benzyl-1,2,3,4-tetrahydroisoquinoline 2d

\section{${ }^{1}$ H NMR}

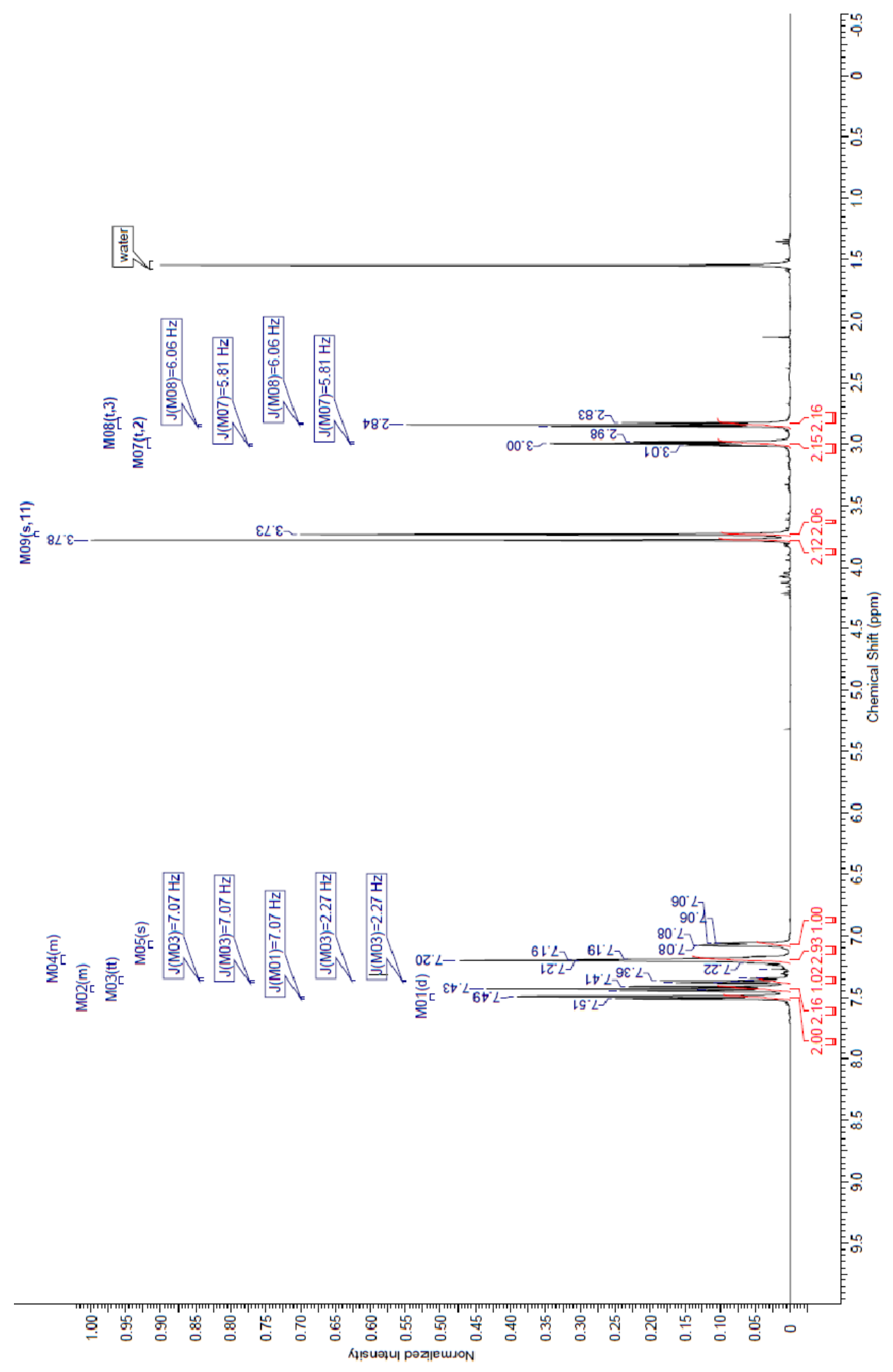




\section{${ }^{1}$ H NMR}

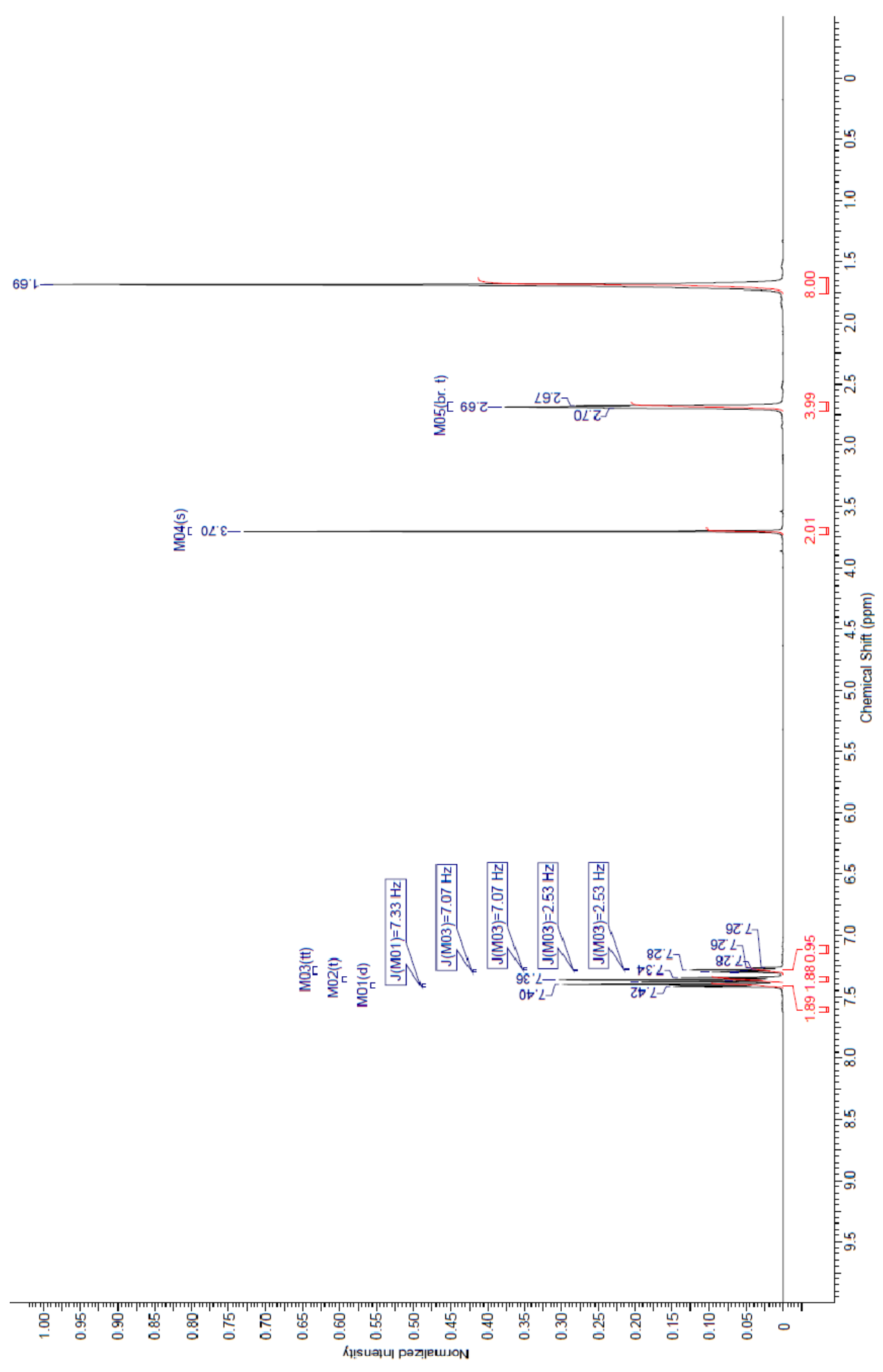


1-(p-Tolyl)piperidine $2 \mathrm{k}$

\section{${ }^{1}$ H NMR}

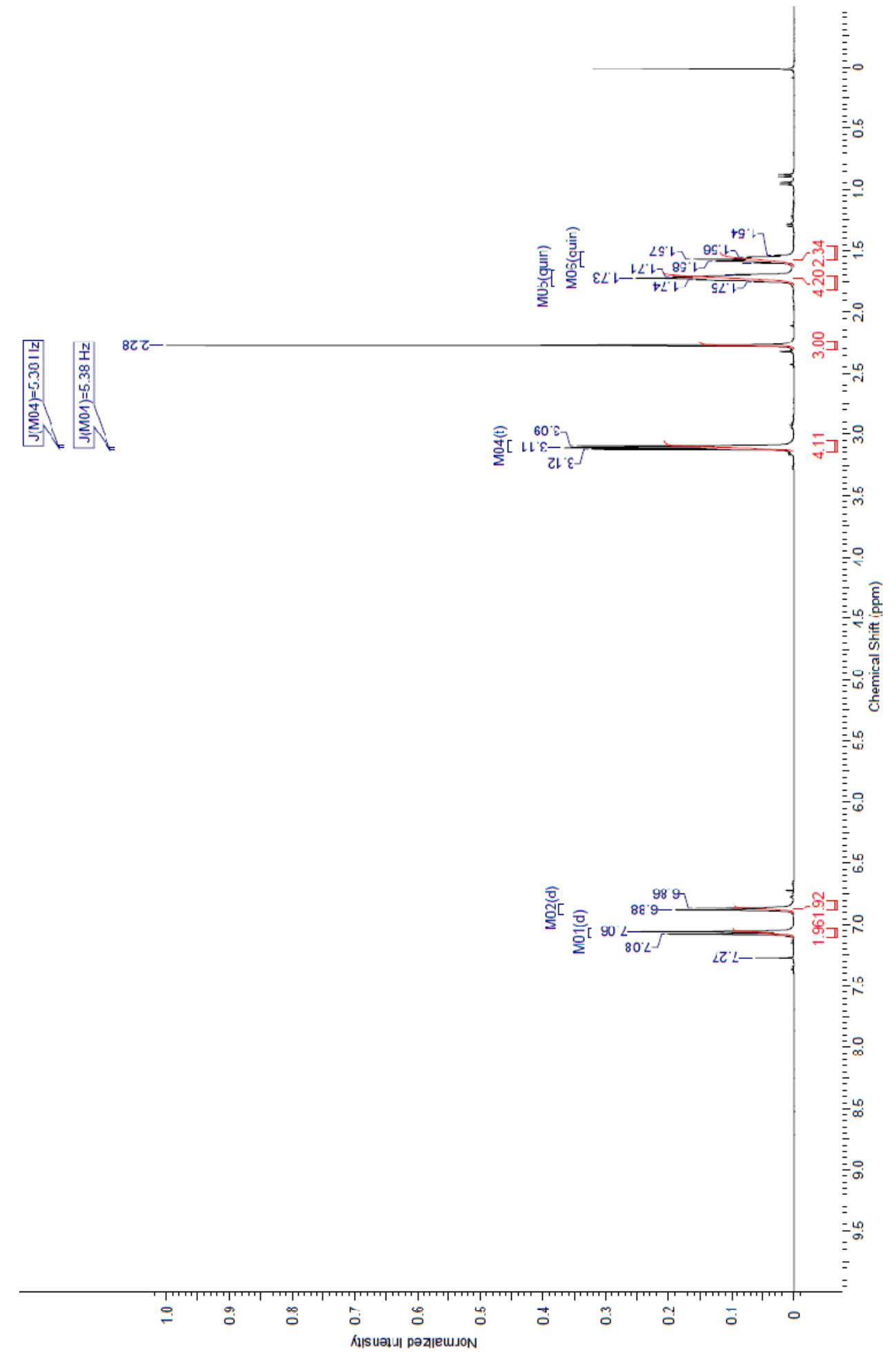


(R)-1-(1-Phenylethyl)piperidine 2m

${ }^{1}$ H NMR

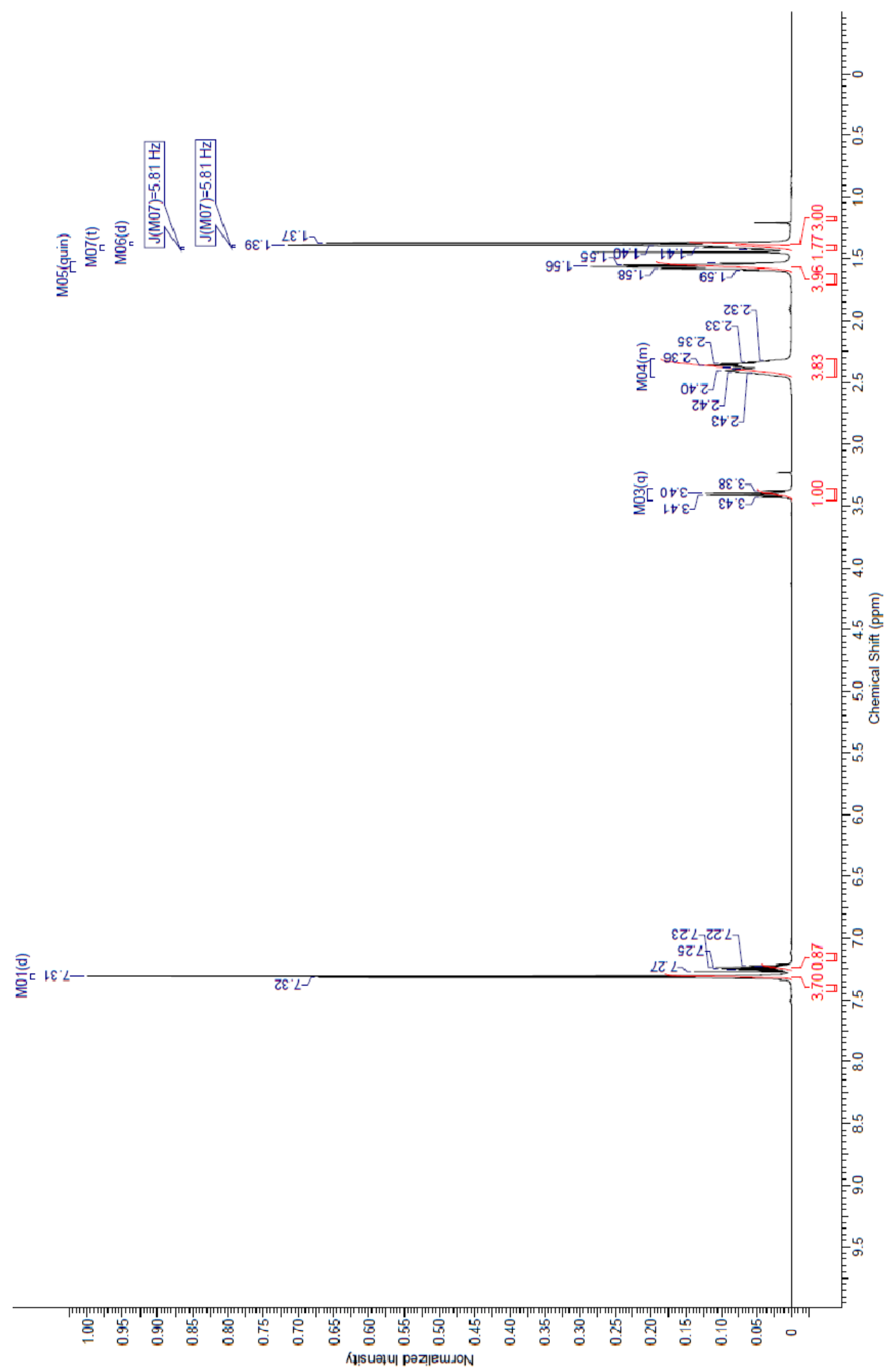


<smiles>COc1ccc(CN2CCCC(C)C2)cc1</smiles>

${ }^{1}$ H NMR

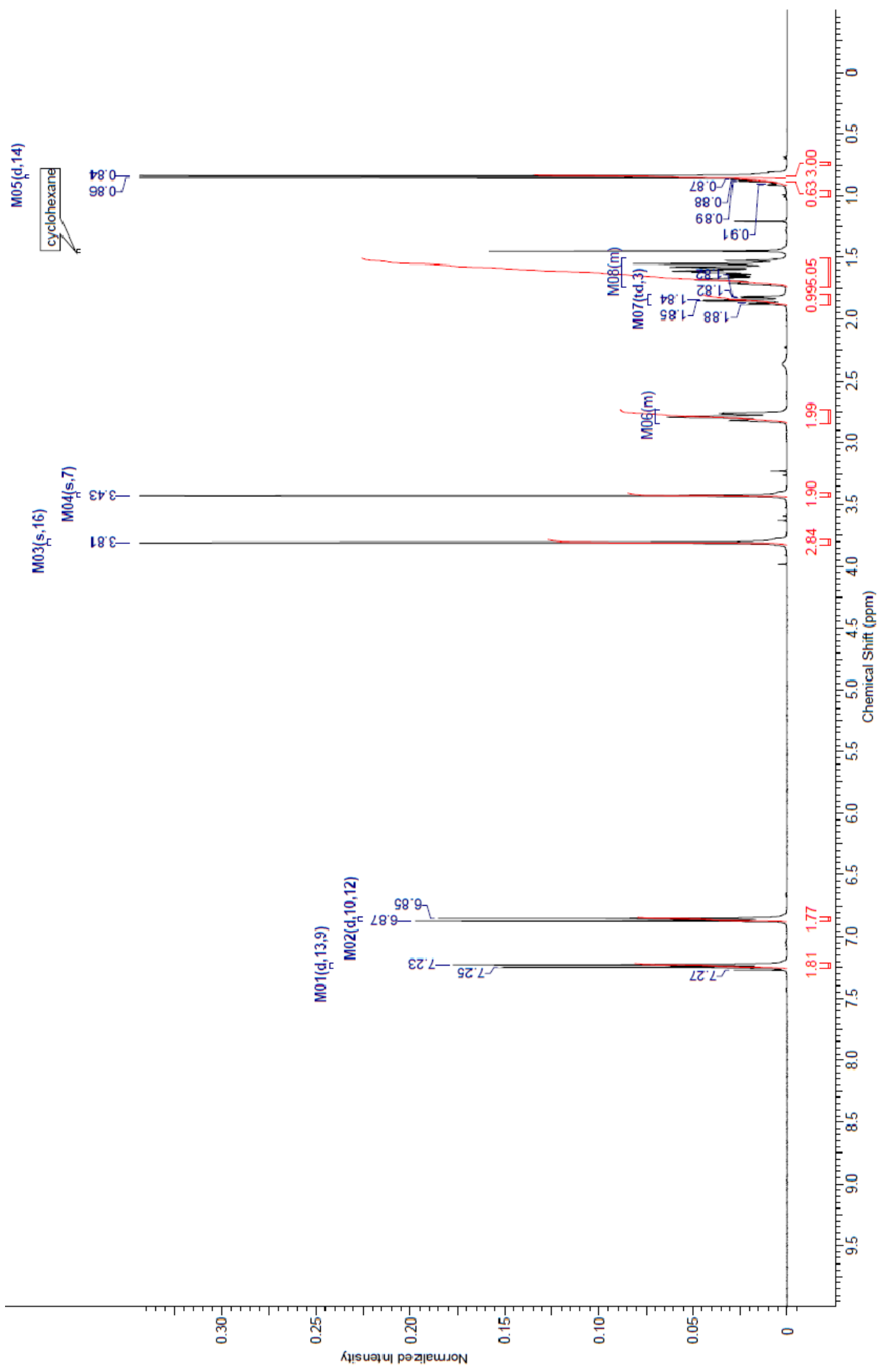


${ }^{13}$ C NMR

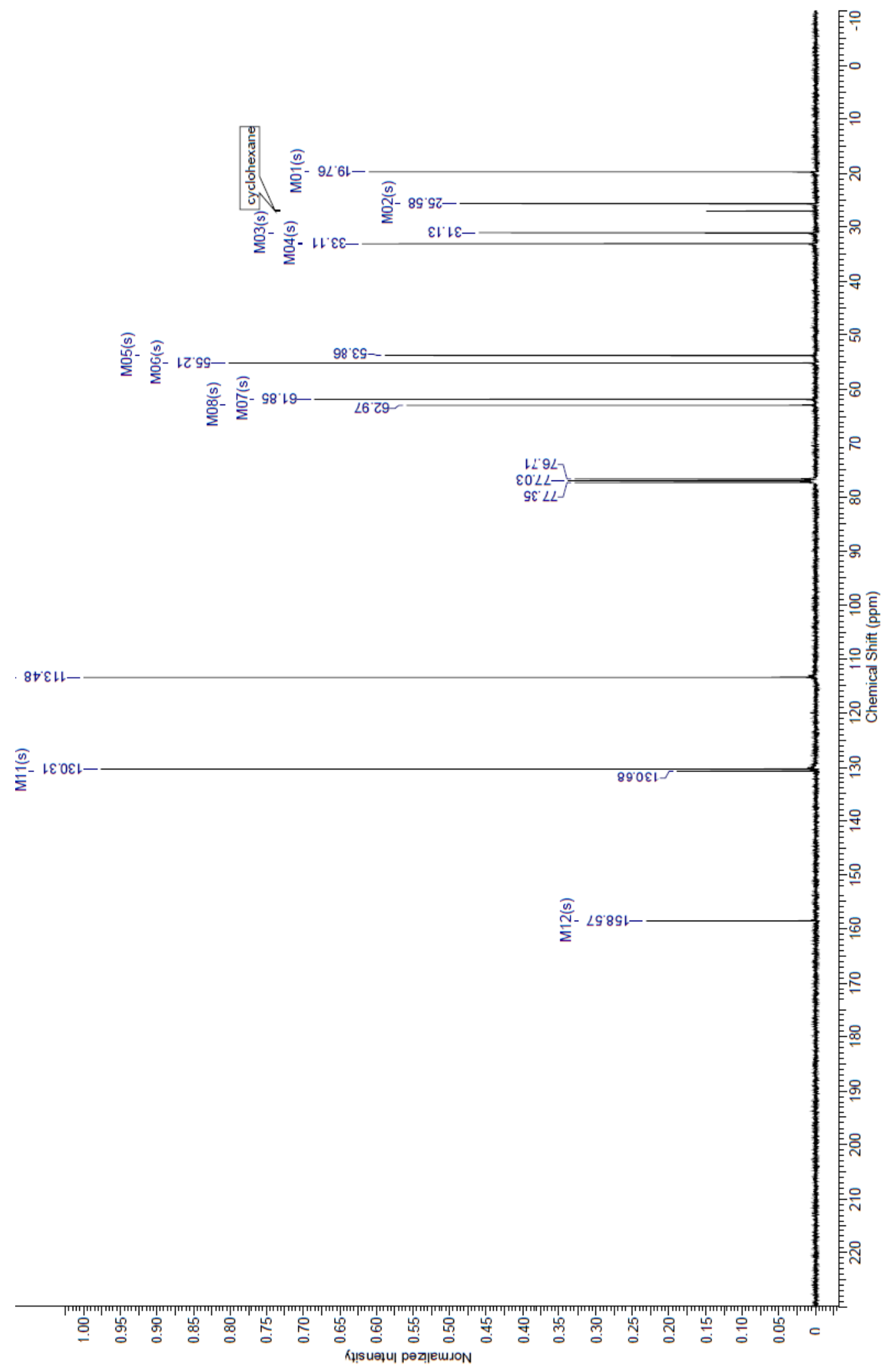


<smiles>COc1ccc(CN2CC(C)OC(C)C2)cc1</smiles>

${ }^{1}$ H NMR

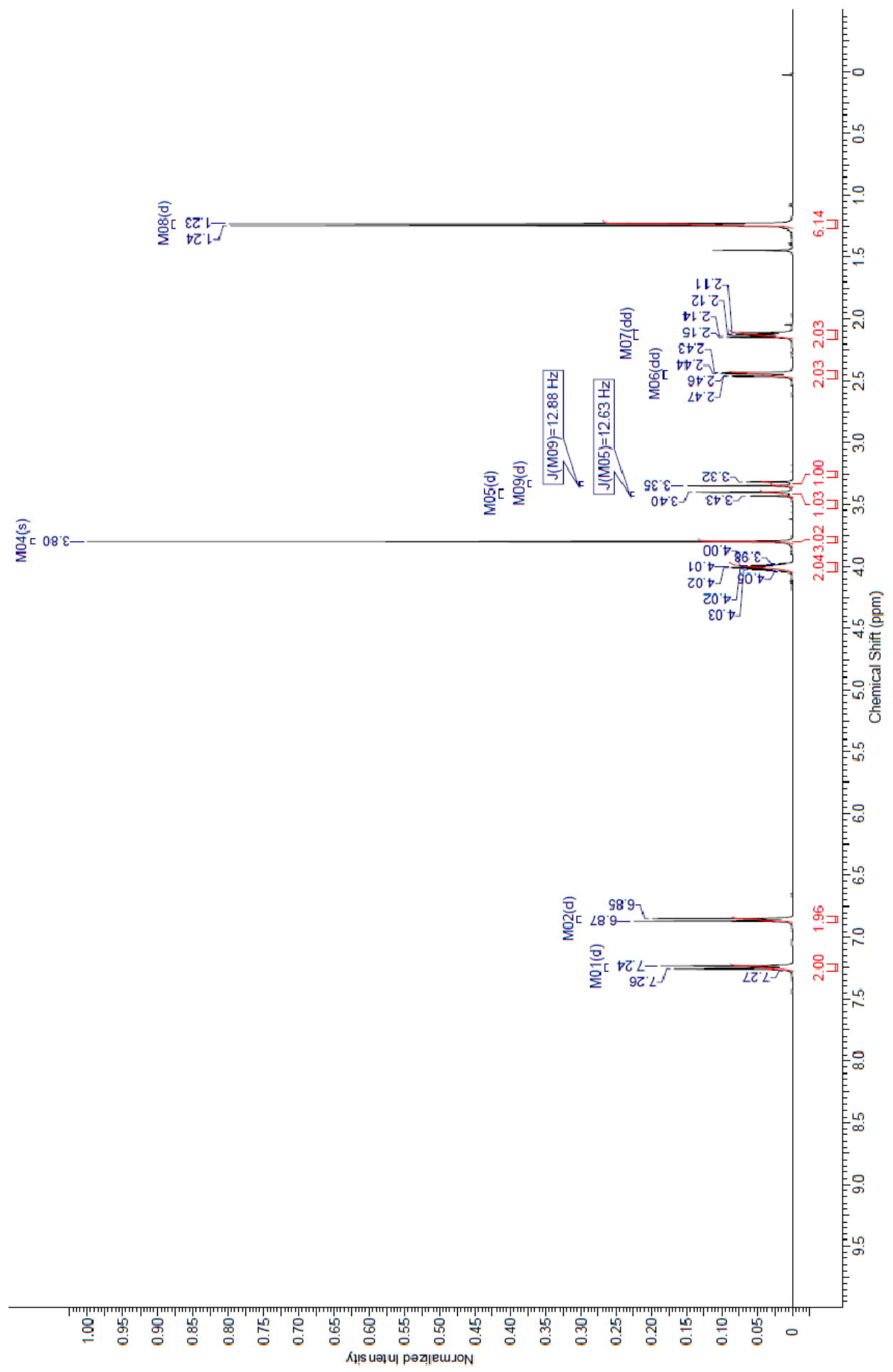


${ }^{13}$ C NMR

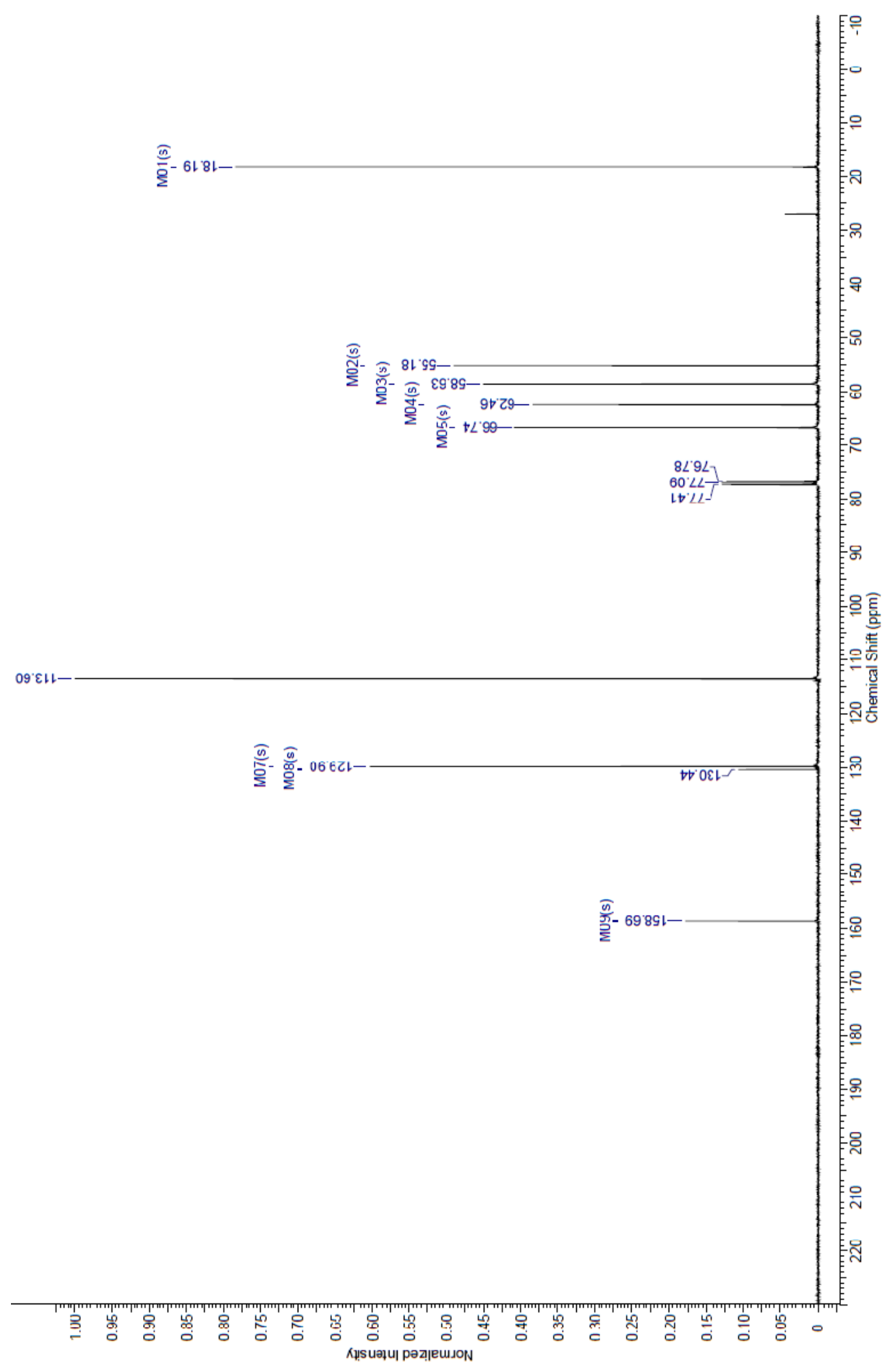


1-(1-Phenylethyl)piperidine 2s

${ }^{1}$ H NMR

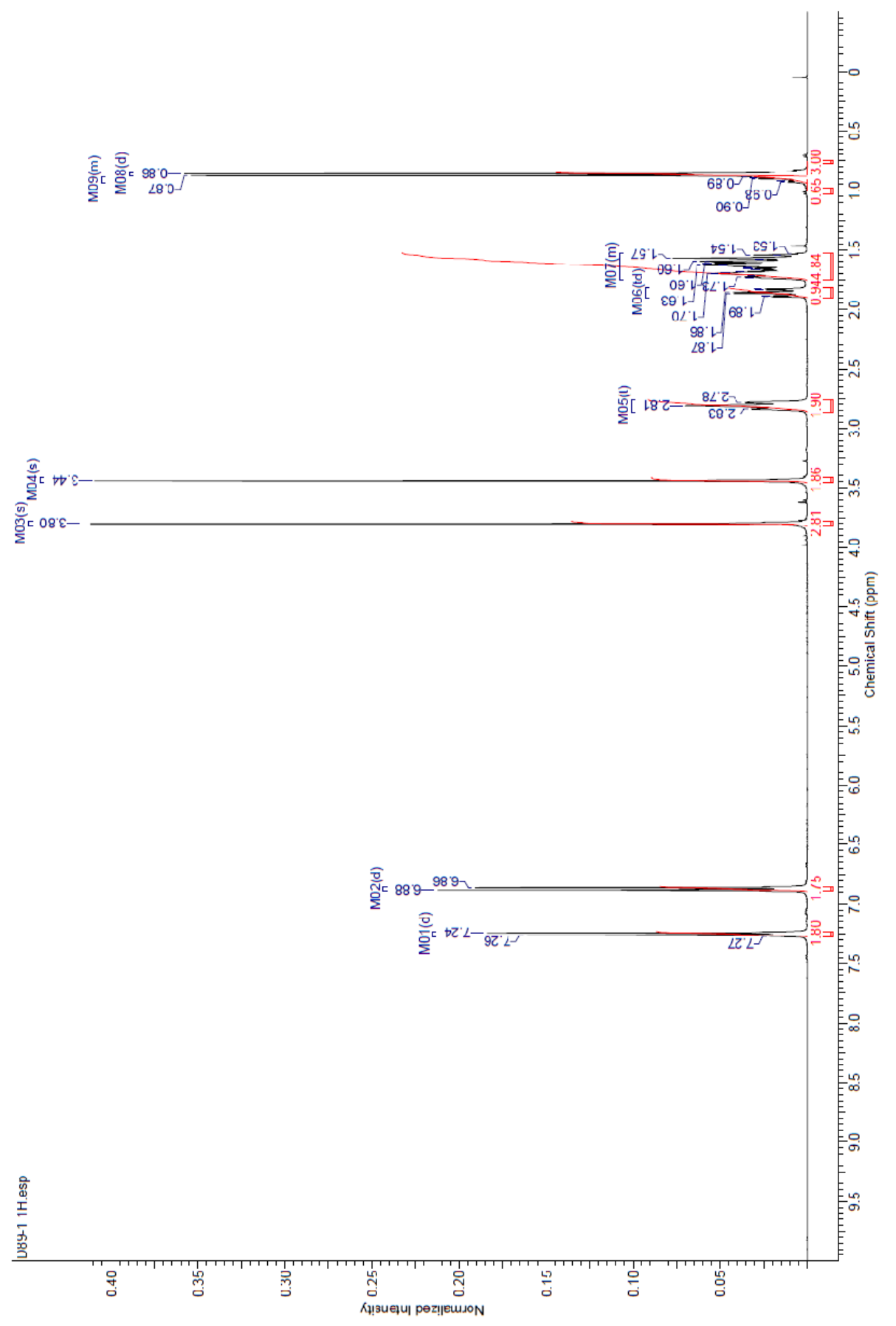




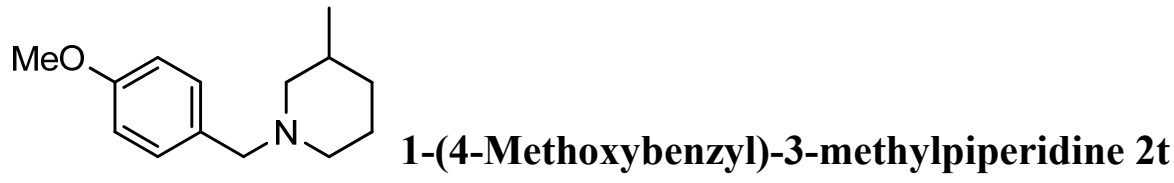

\section{${ }^{1}$ H NMR}

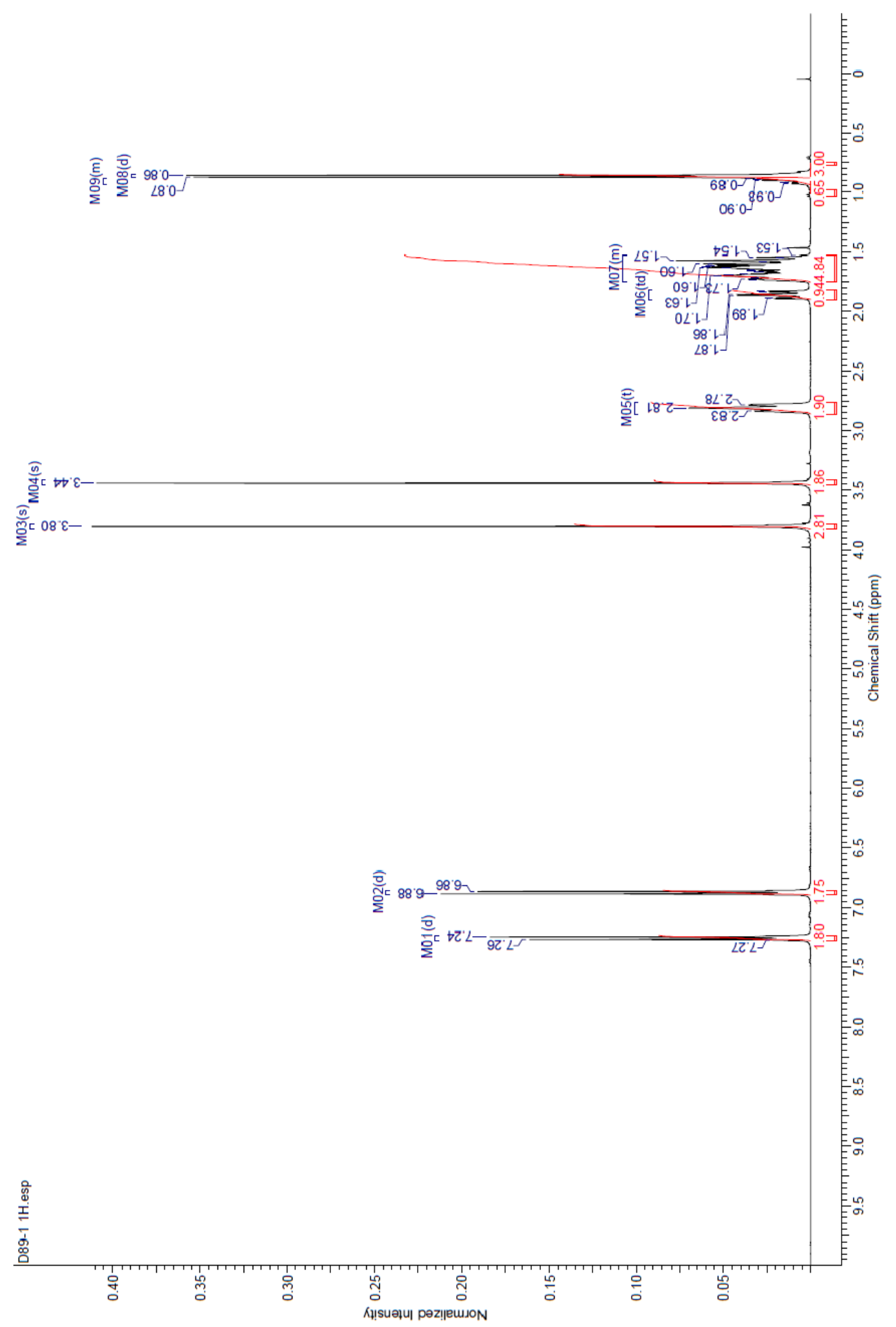


1-Benzylpiperidin-2-one 3a

\section{${ }^{1}$ H NMR}

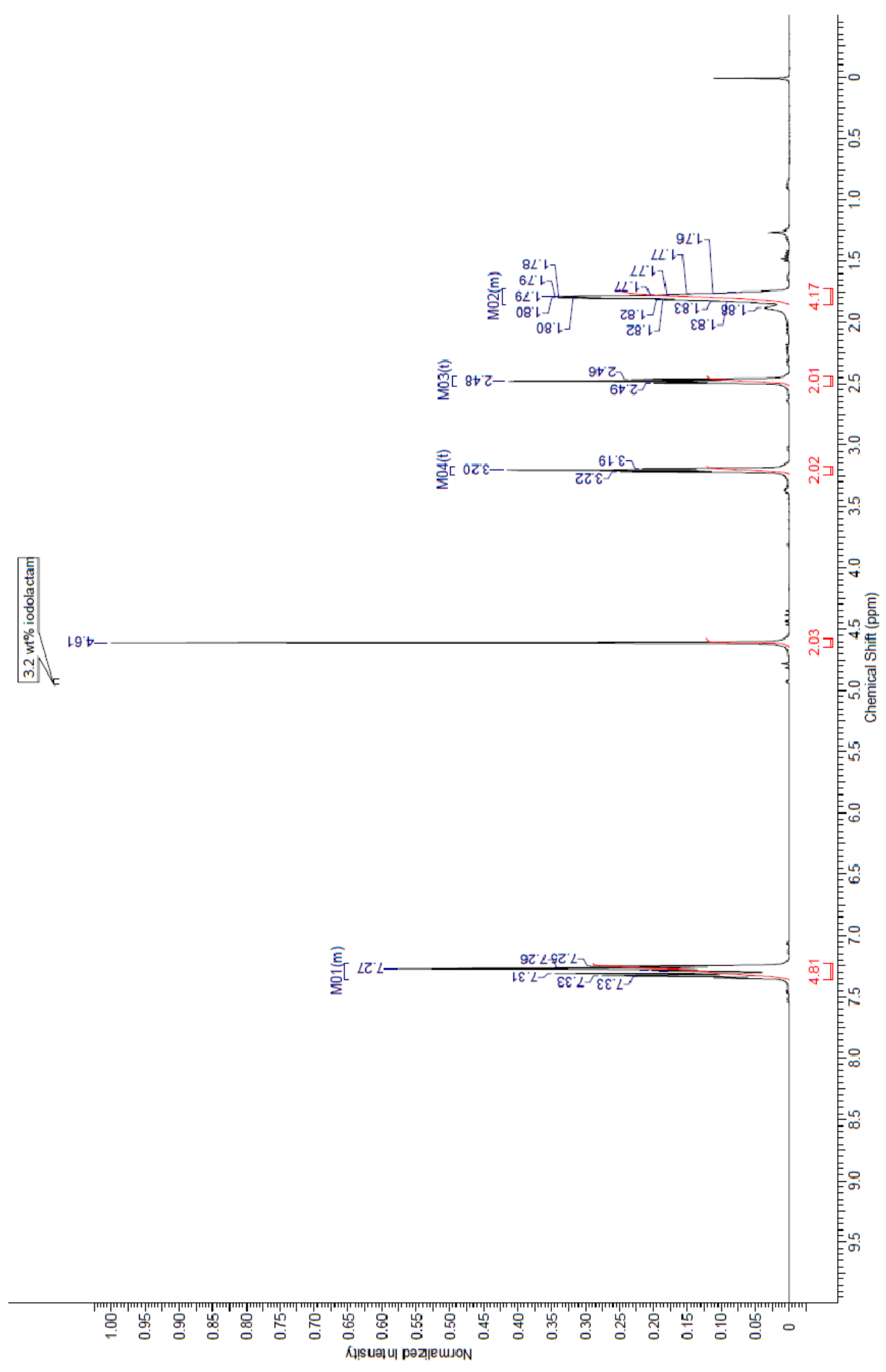


${ }^{13}$ C NMR

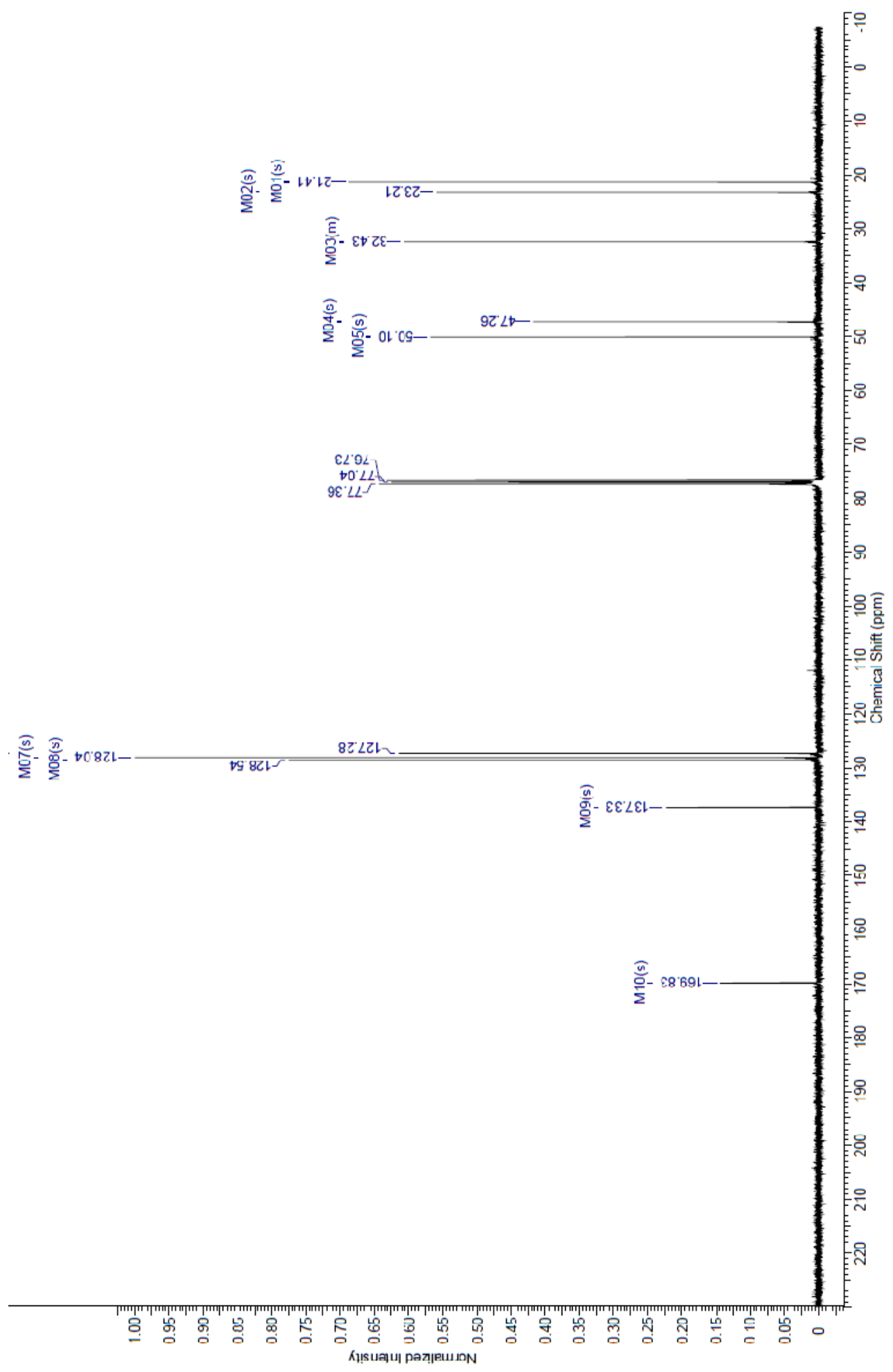


1-(4-Methoxybenzyl)piperidin-2-one 3b

\section{${ }^{1}$ H NMR}

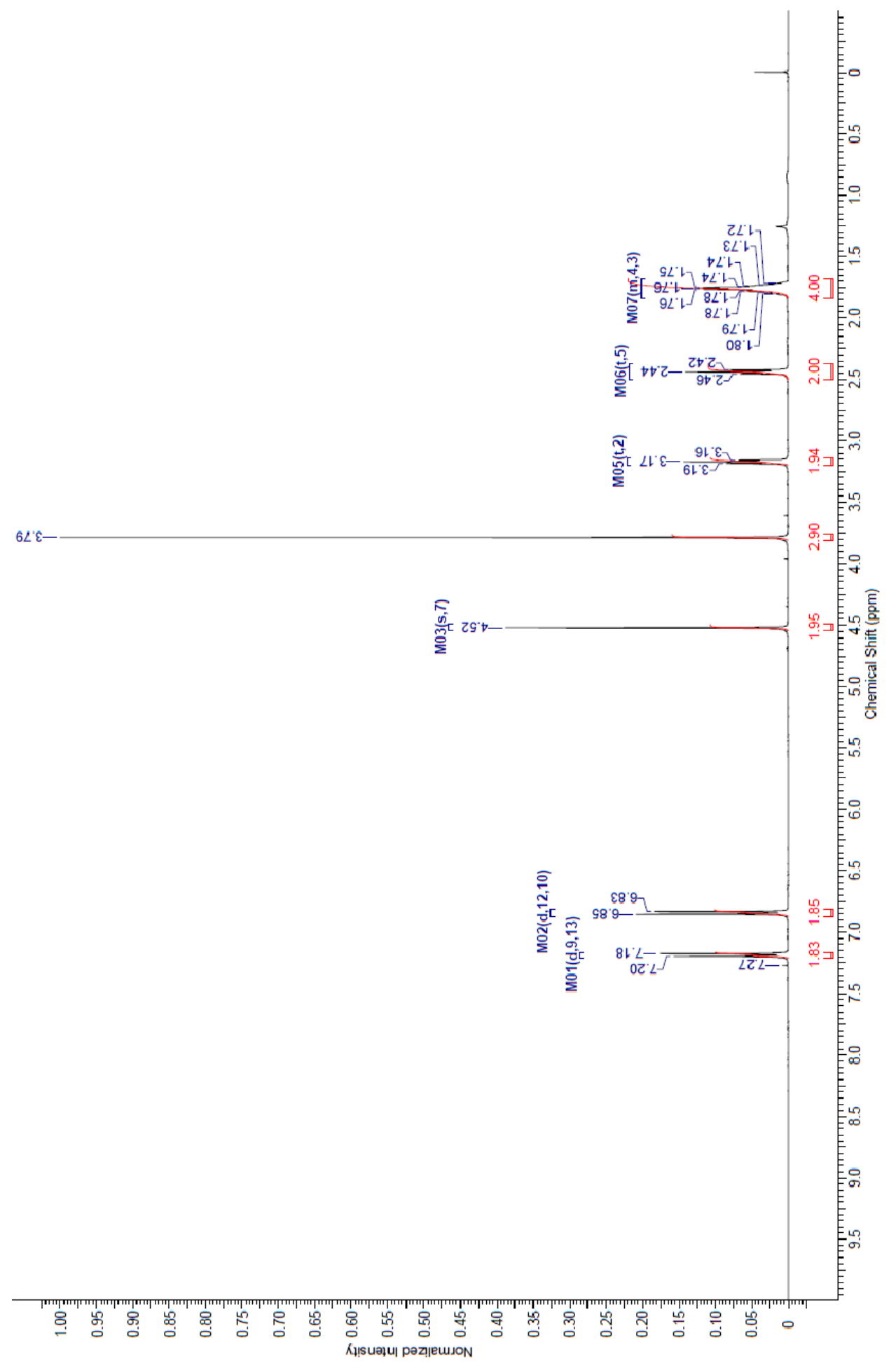


${ }^{13}$ C NMR

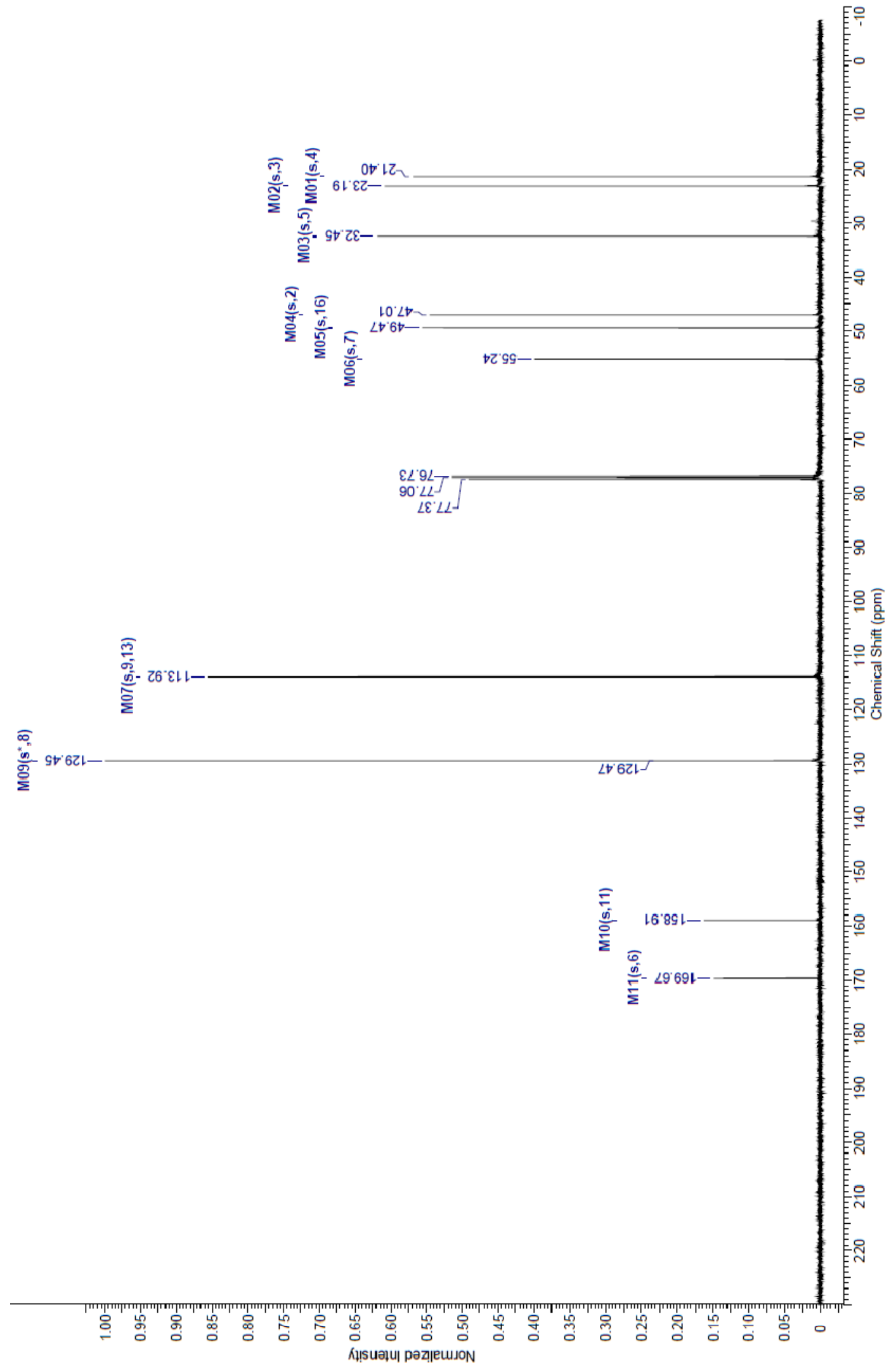


1-(4-Nitrobenzyl)piperidin-2-one 3c

\section{${ }^{1}$ H NMR}

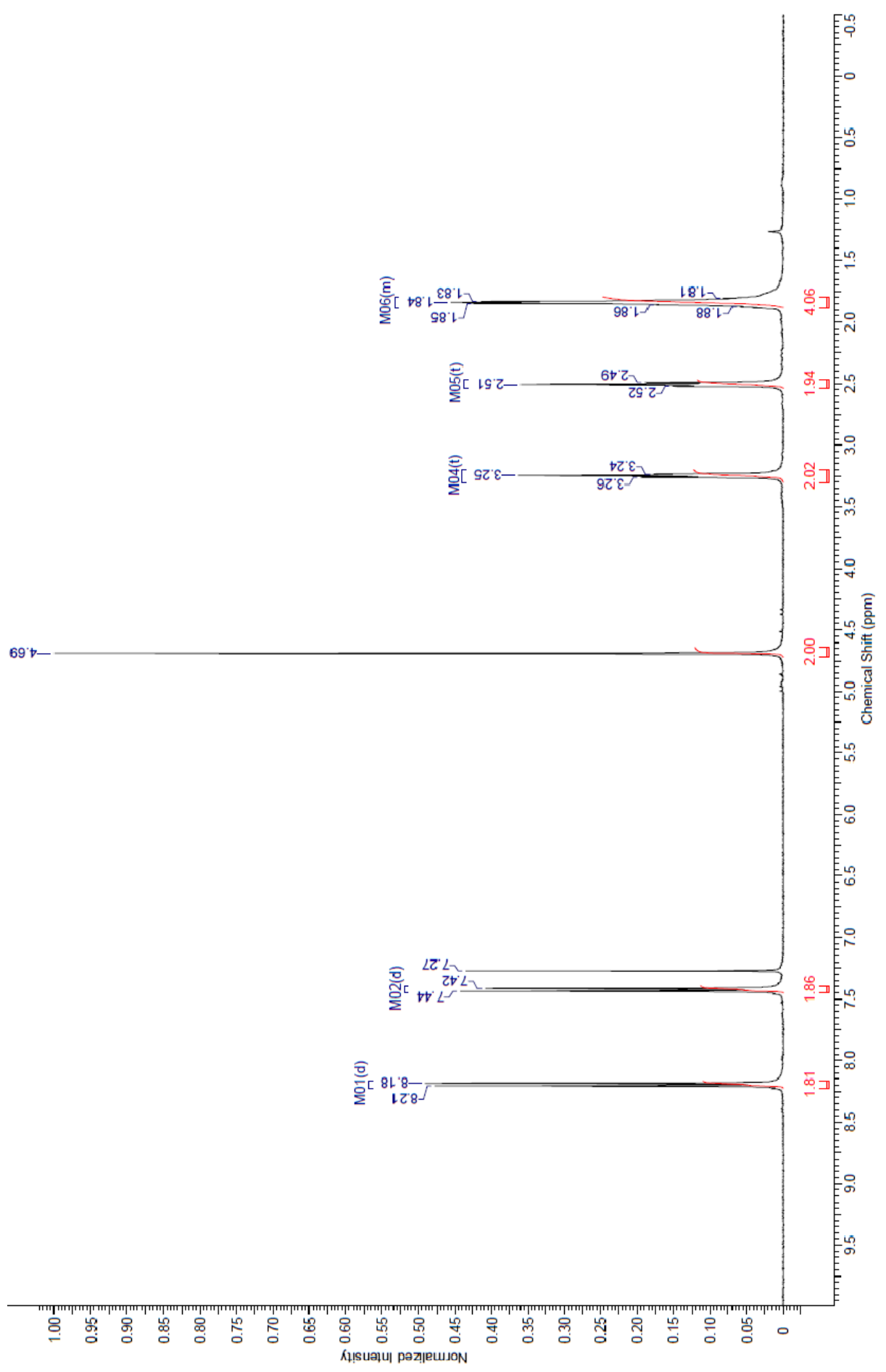


${ }^{13}$ C NMR

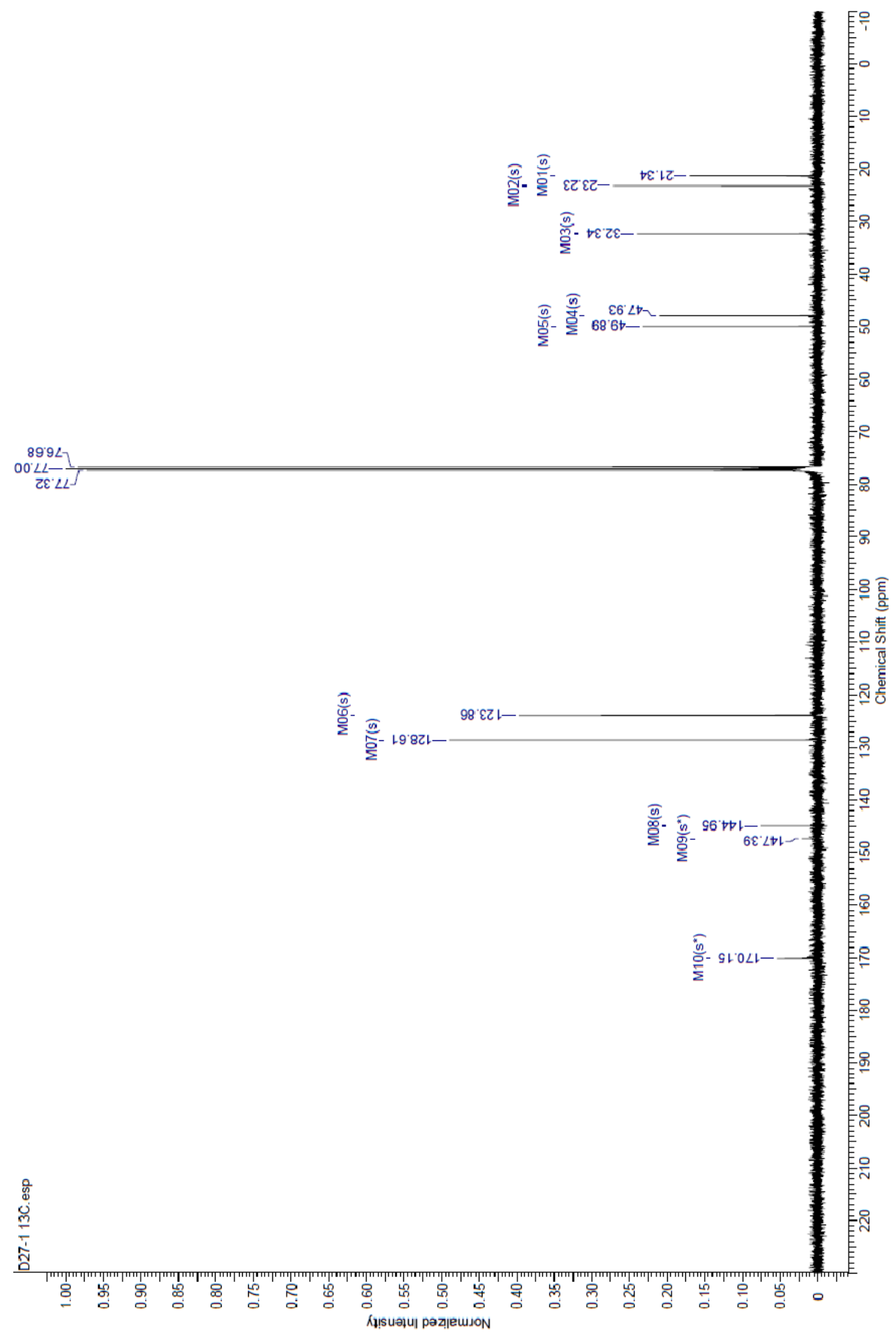

70 


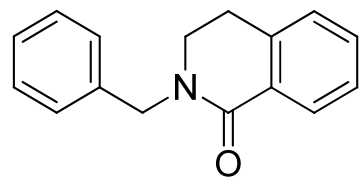

2-Benzyl-3,4-dihydroisoquinolin-1(2H)-one 3d

\section{${ }^{1}$ H NMR}
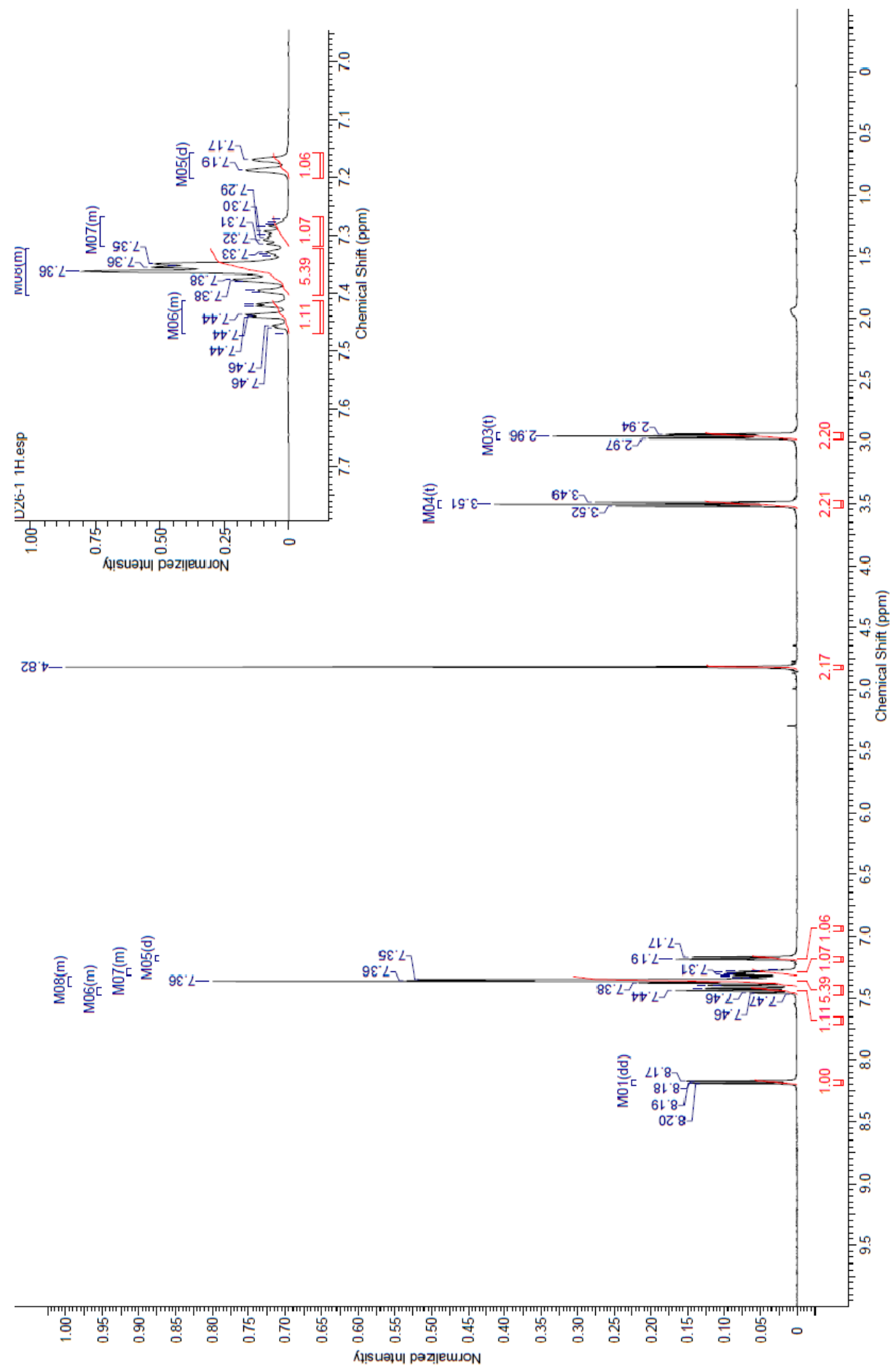


\section{${ }^{13}$ C NMR}

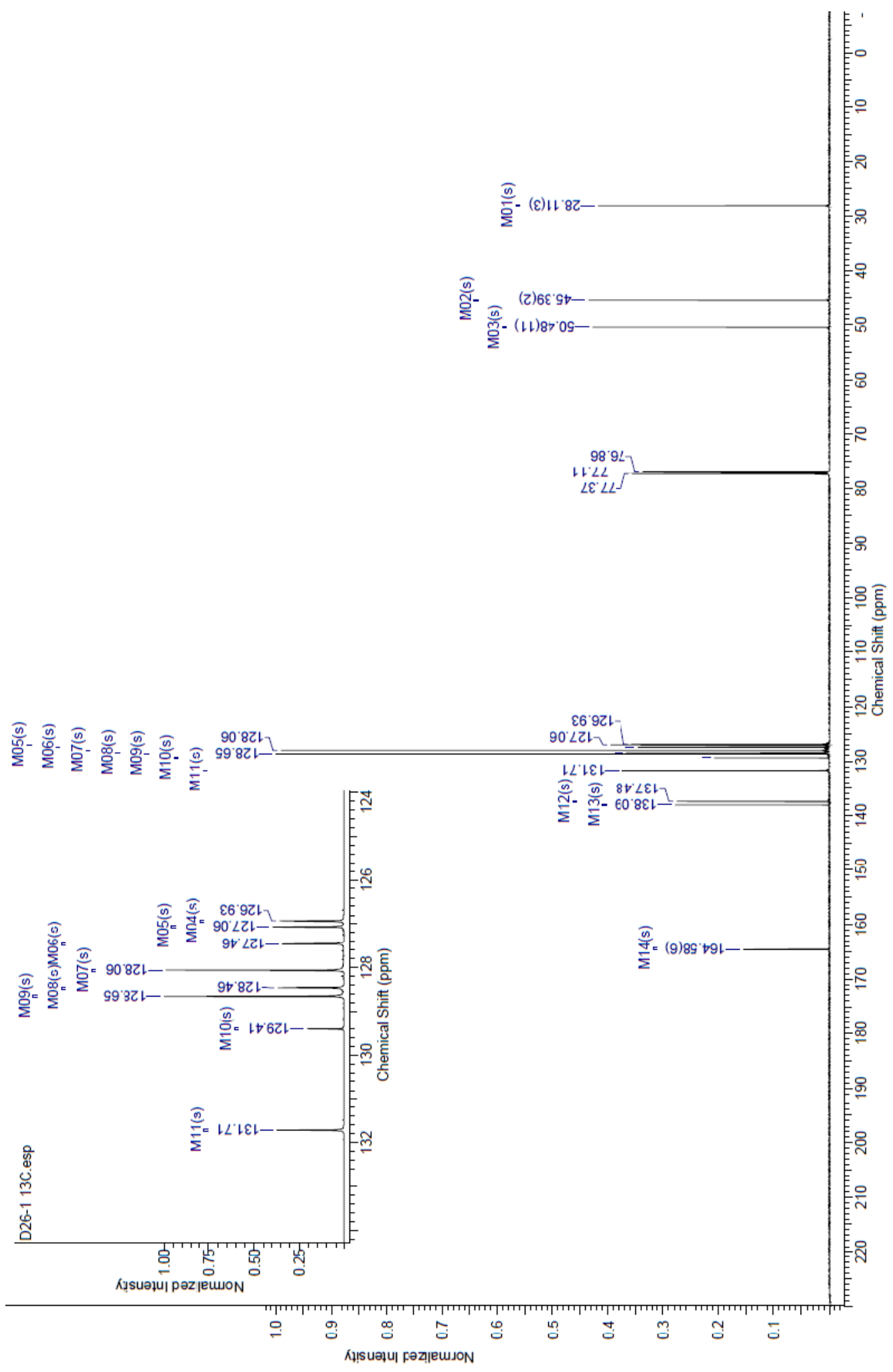




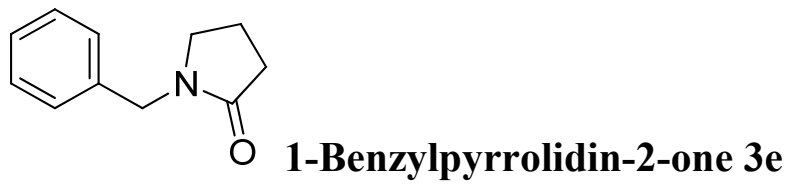

${ }^{1}$ H NMR

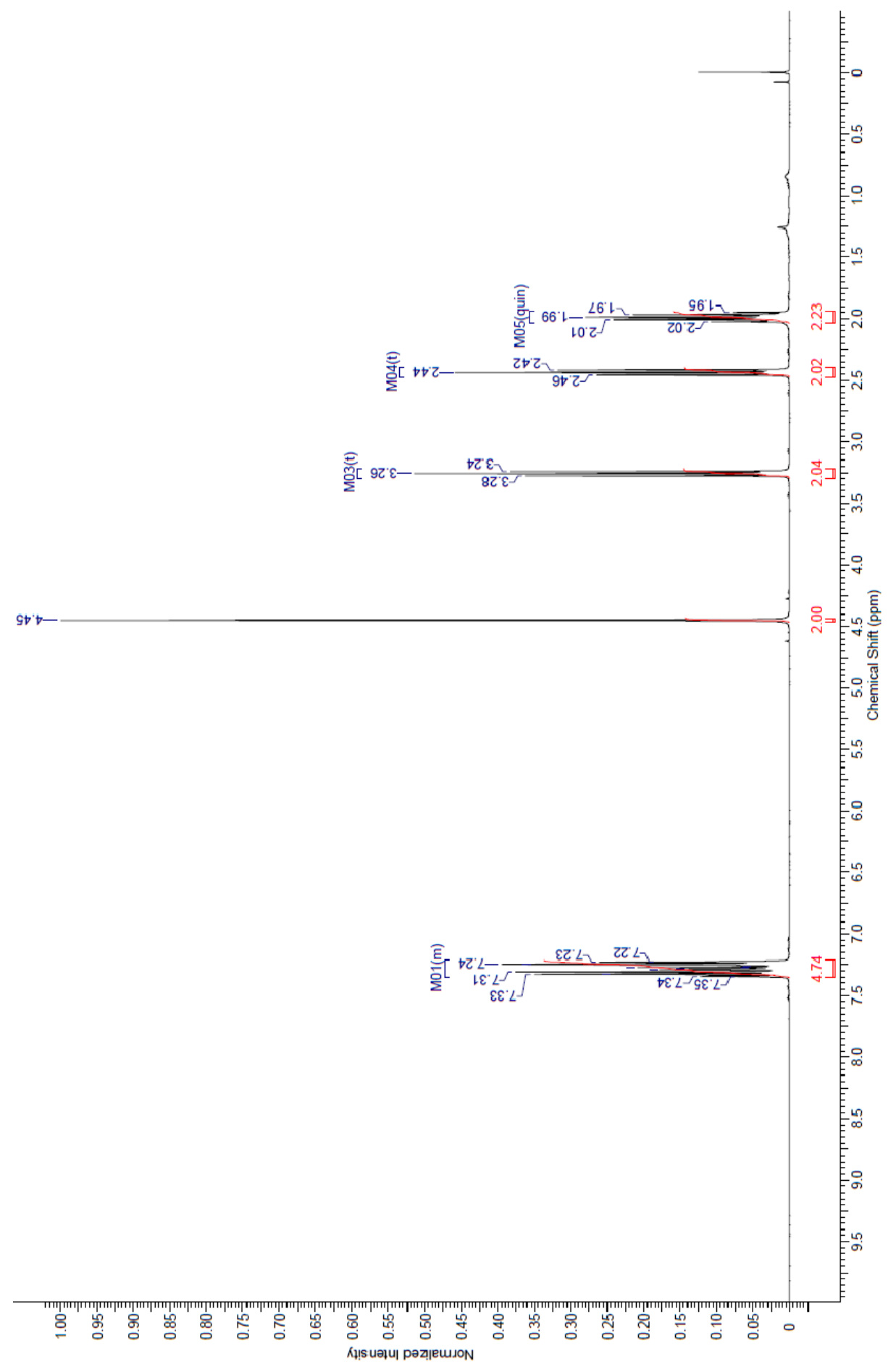


${ }^{13}$ C NMR

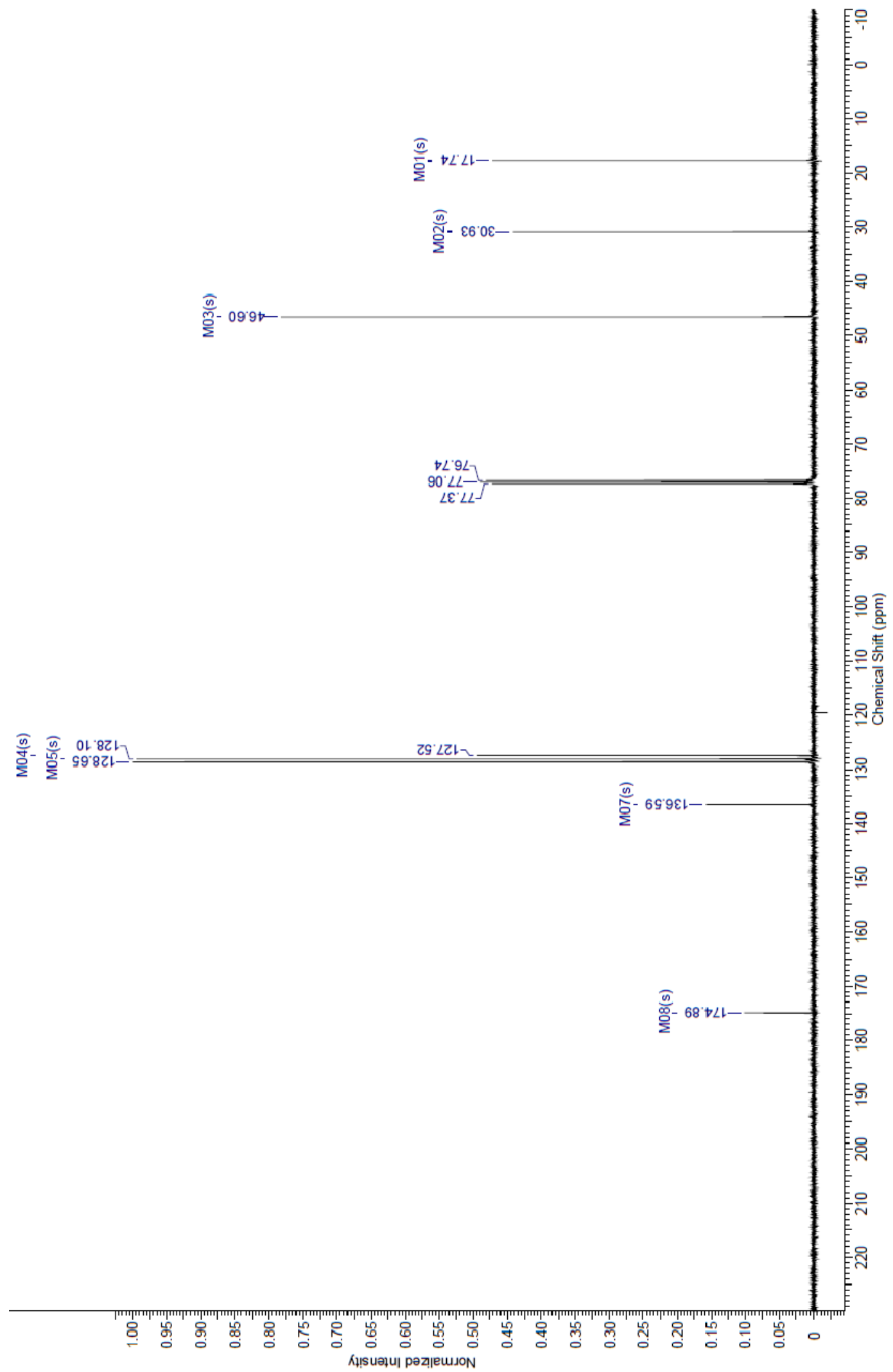


$\sim \prod_{0}$

1-Benzylazepan-2-one $3 f$

\section{${ }^{1}$ H NMR}

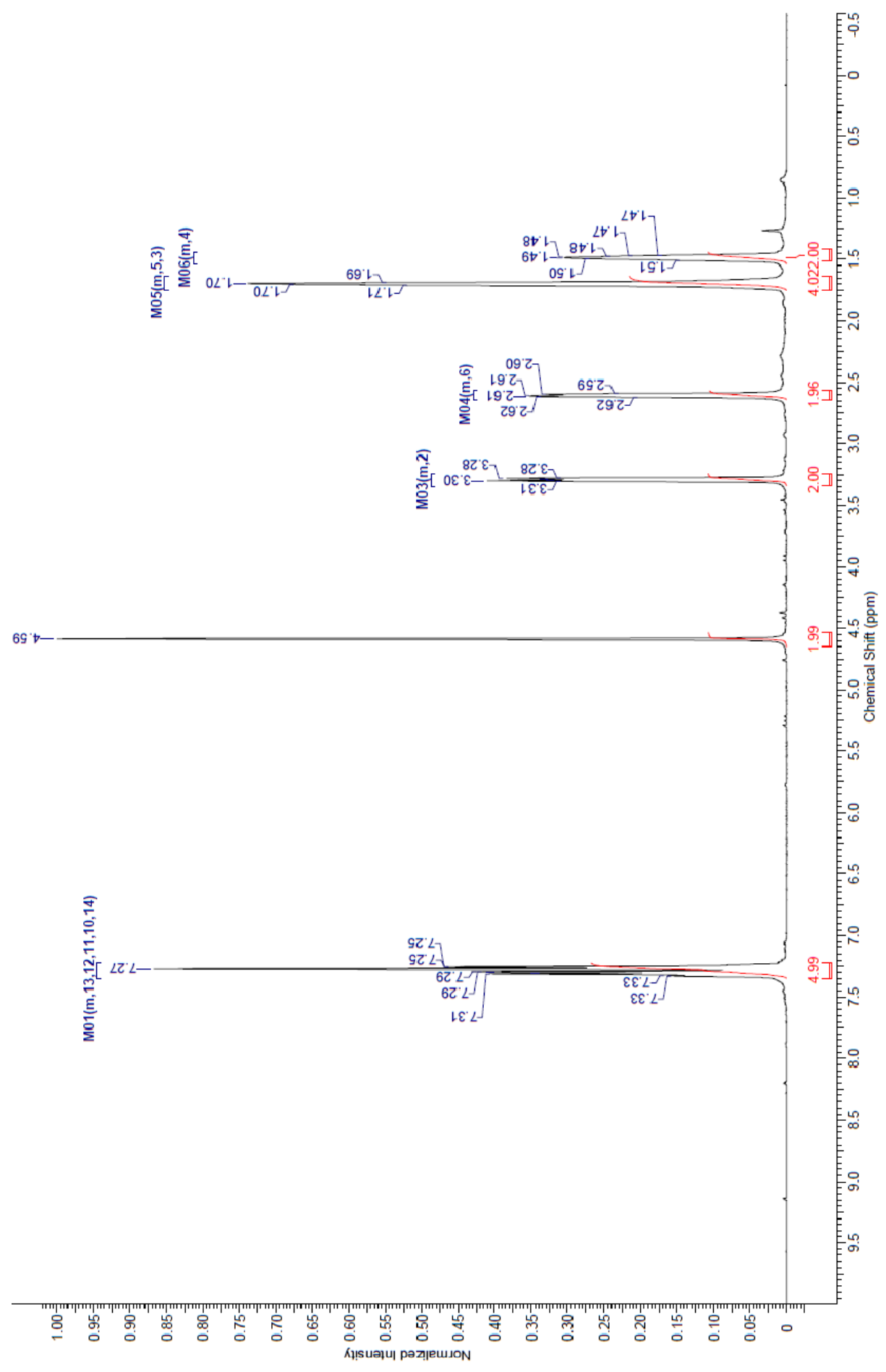


${ }^{13}$ C NMR

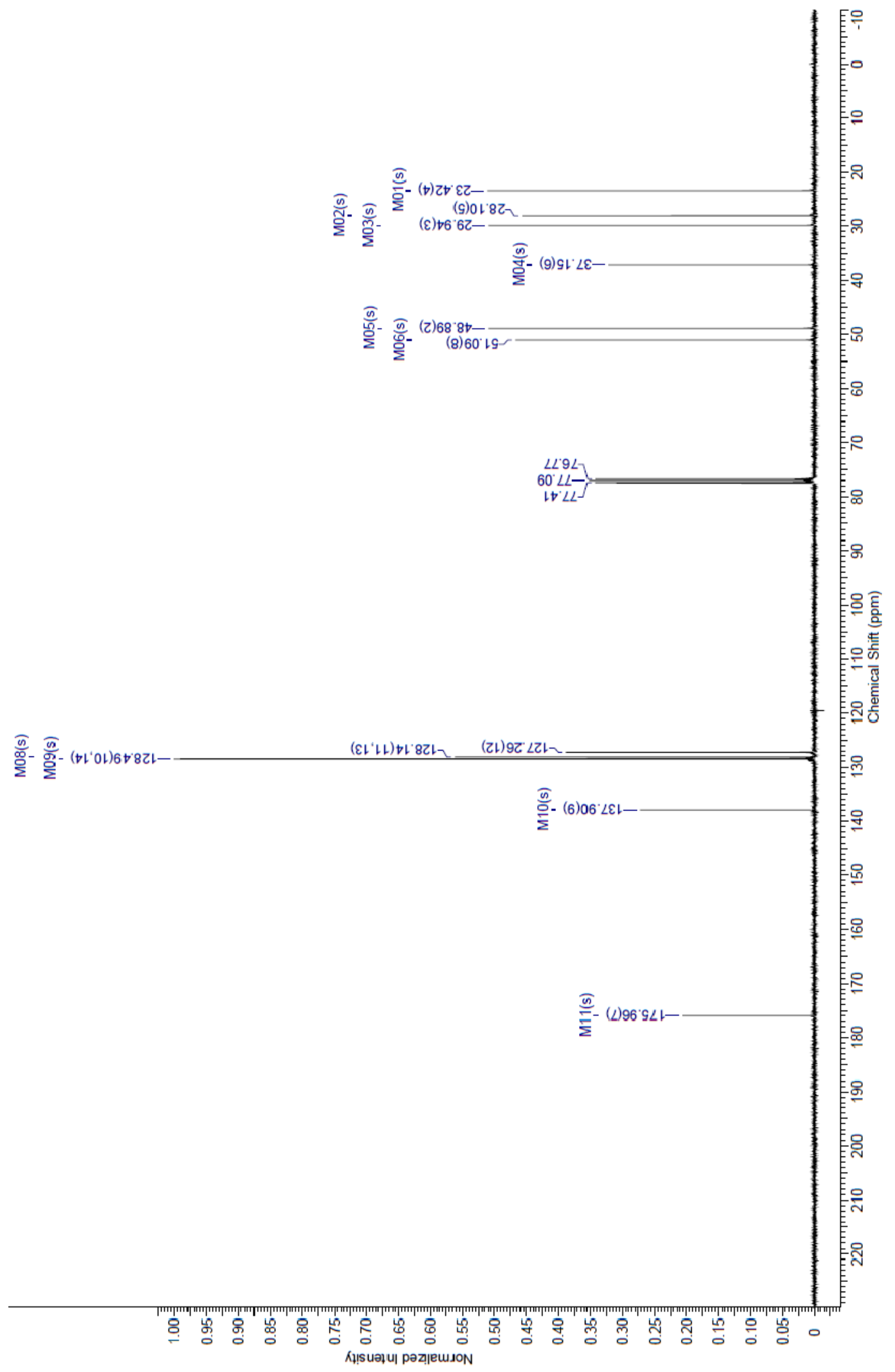


4-Benzylmorpholin-3-one 3g

\section{${ }^{1}$ H NMR}

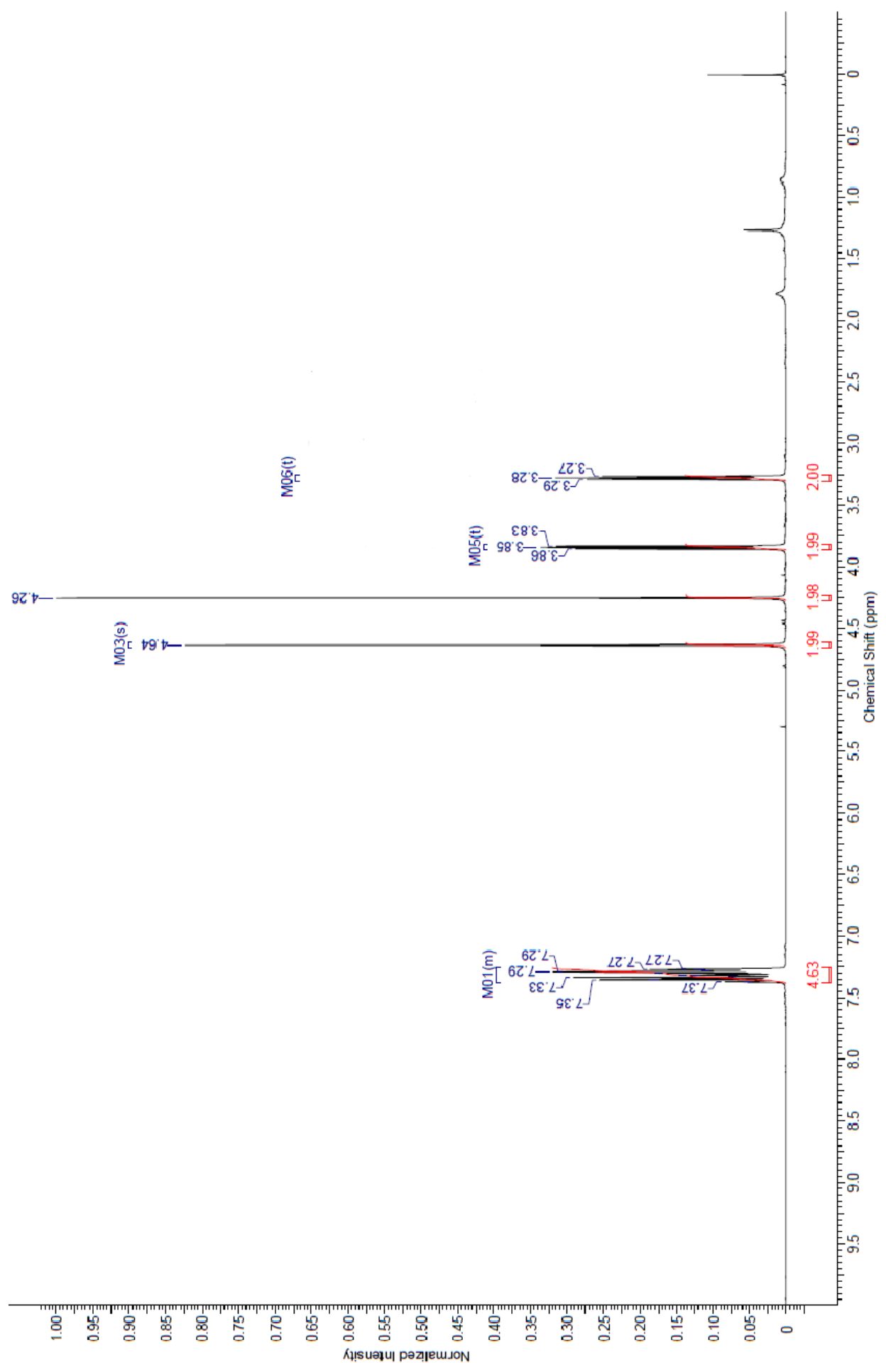


${ }^{13}$ C NMR

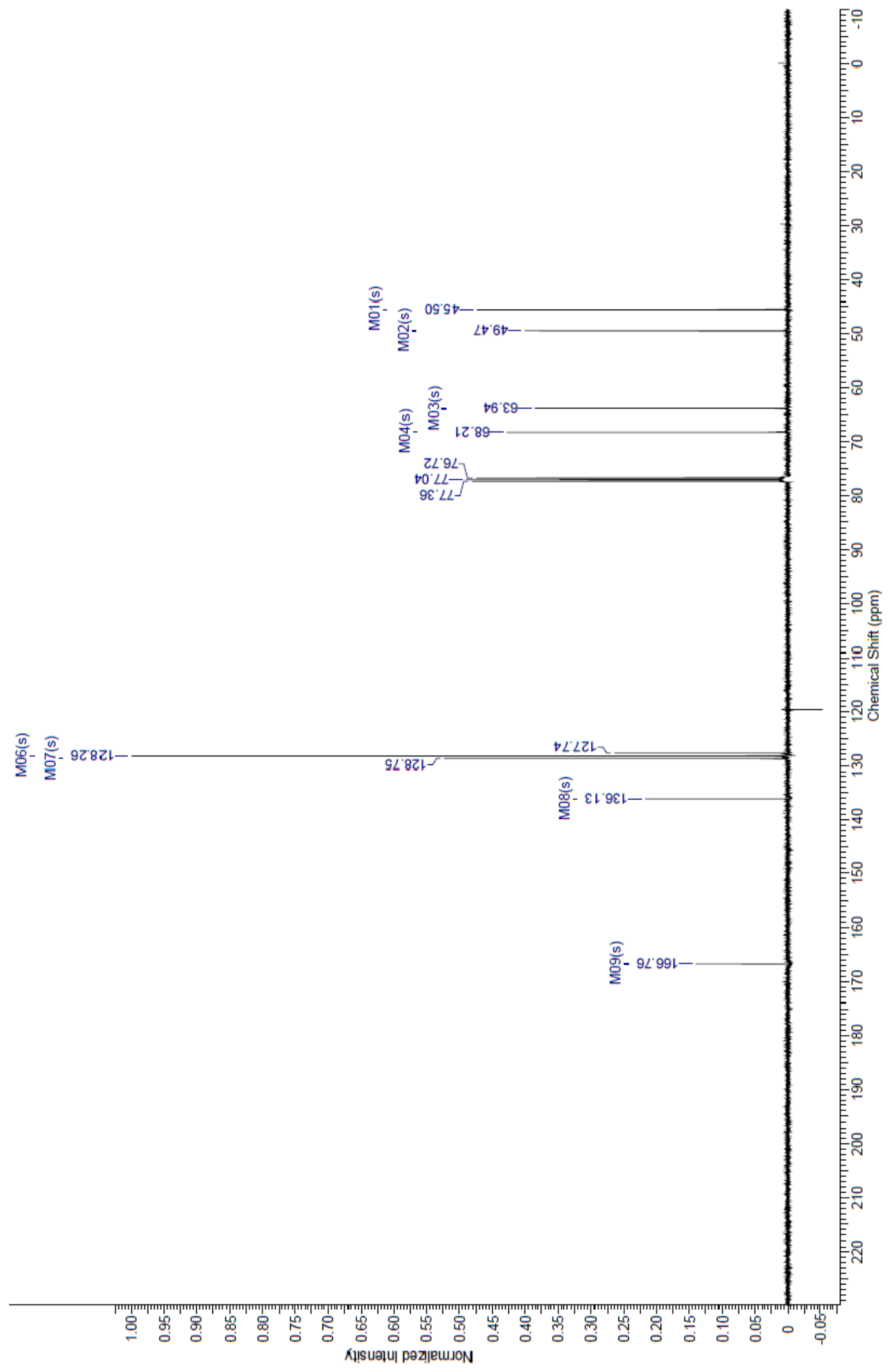


$\overbrace{\mathrm{O}}^{\mathrm{NBoc}}$

Tert-butyl 4-benzyl-3-oxopiperazine-1-carboxylate $3 \mathrm{~h}$

\section{${ }^{1}$ H NMR}

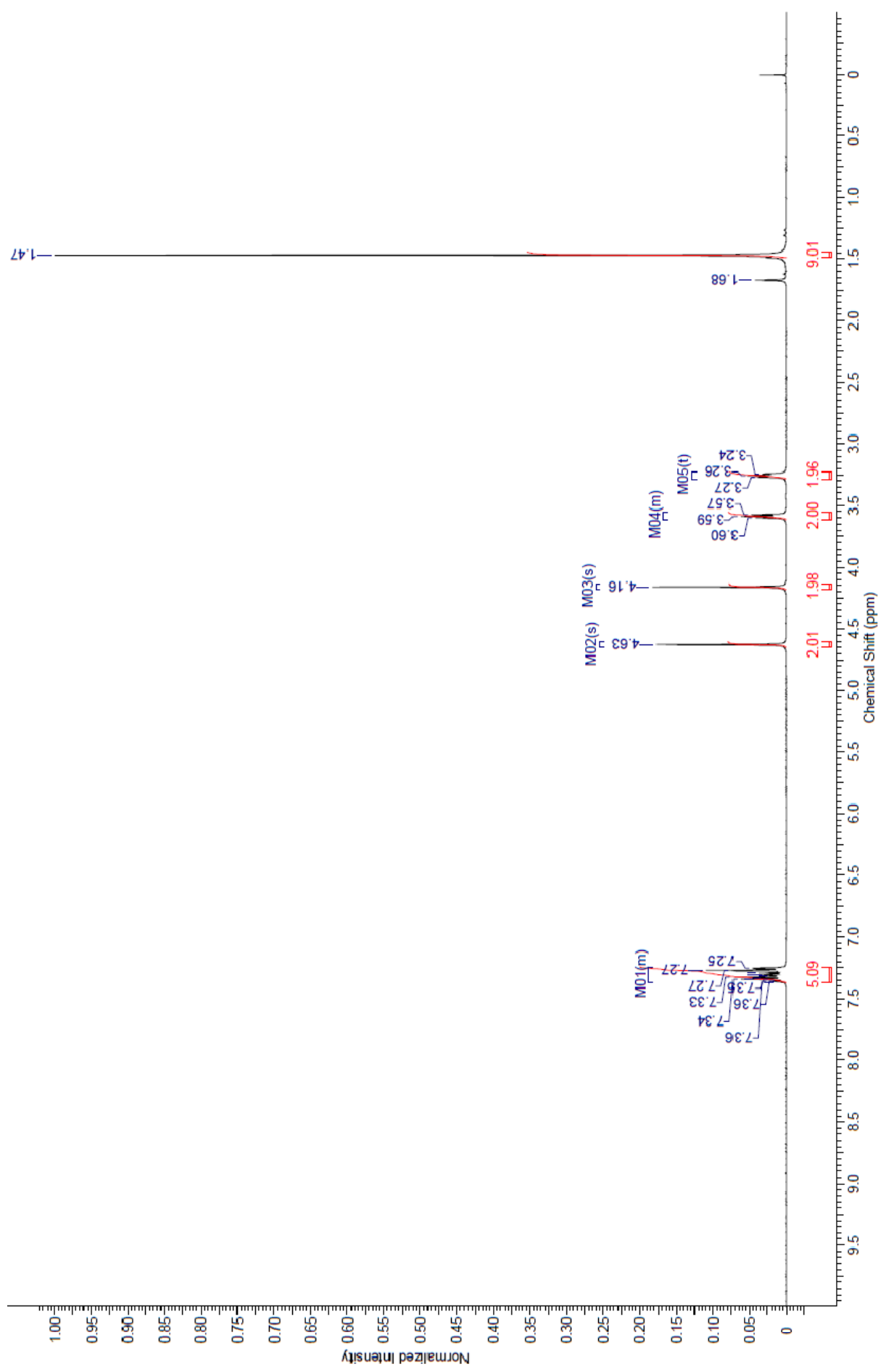


${ }^{13}$ C NMR

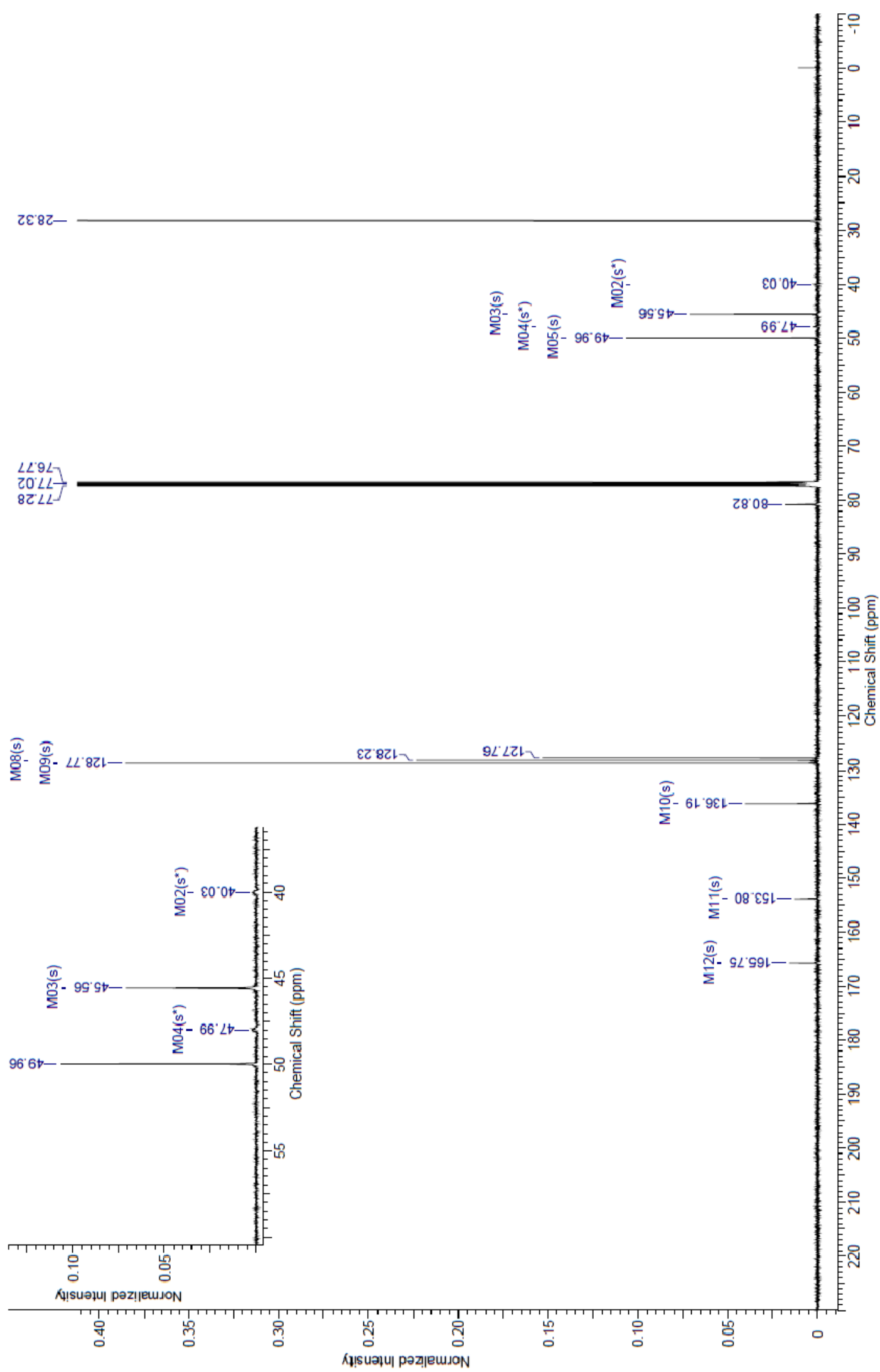


4-Benzyl-1-methylpiperazin-2-one 3i

${ }^{1}$ H NMR

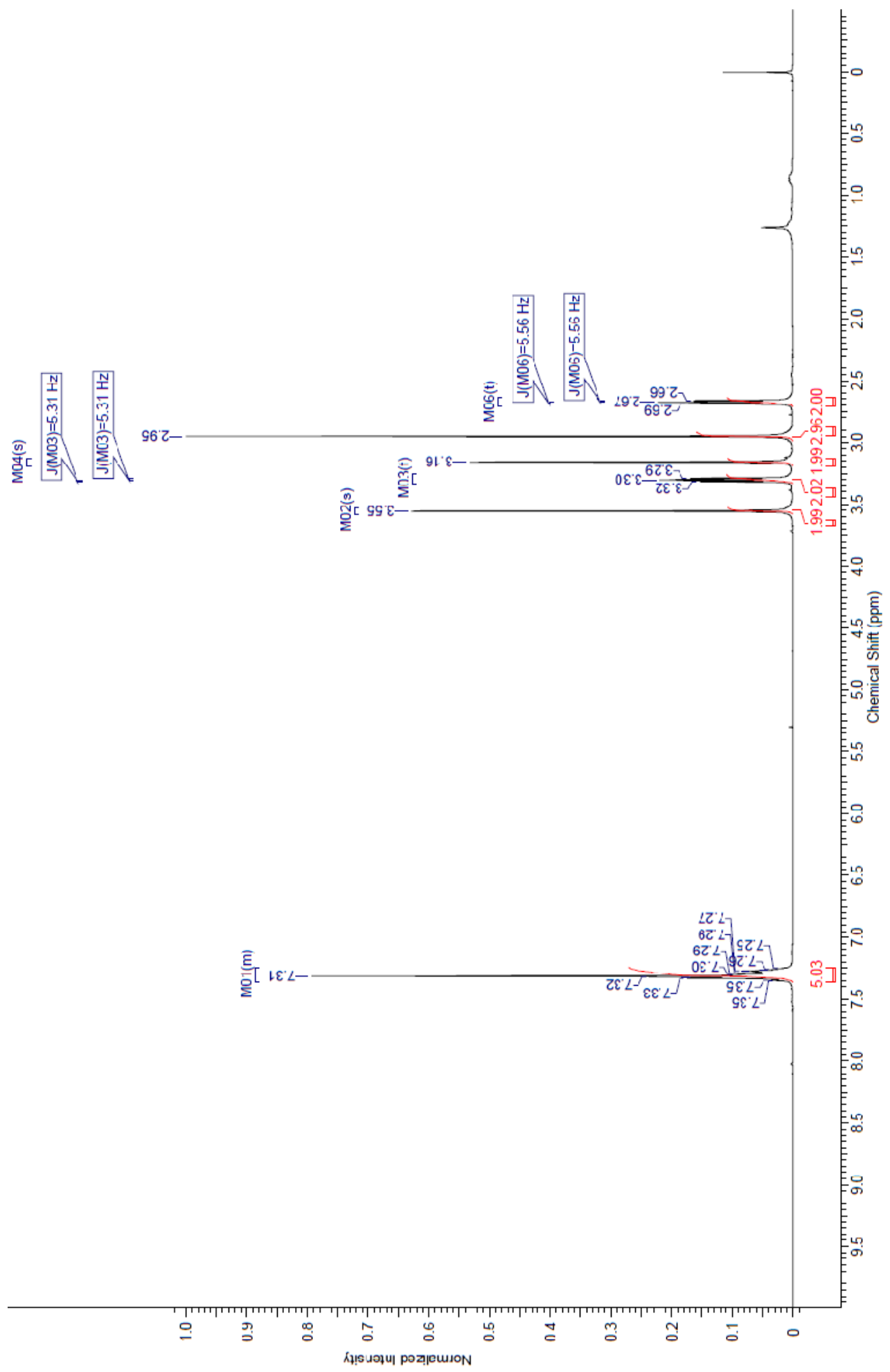


${ }^{13}$ C NMR

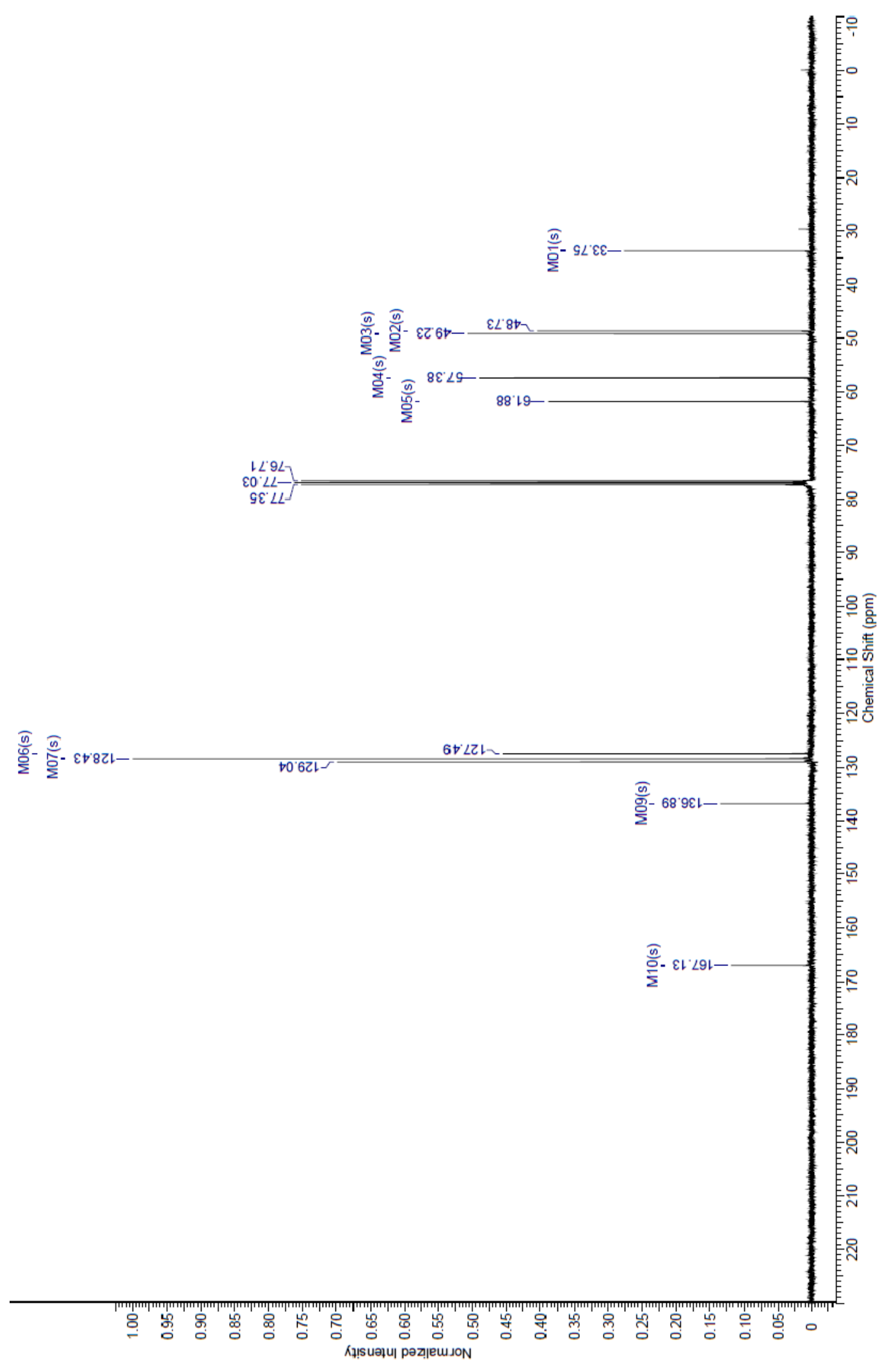

82 
1-(4-Iodophenyl)piperidin-2-one 3j

${ }^{1}$ H NMR

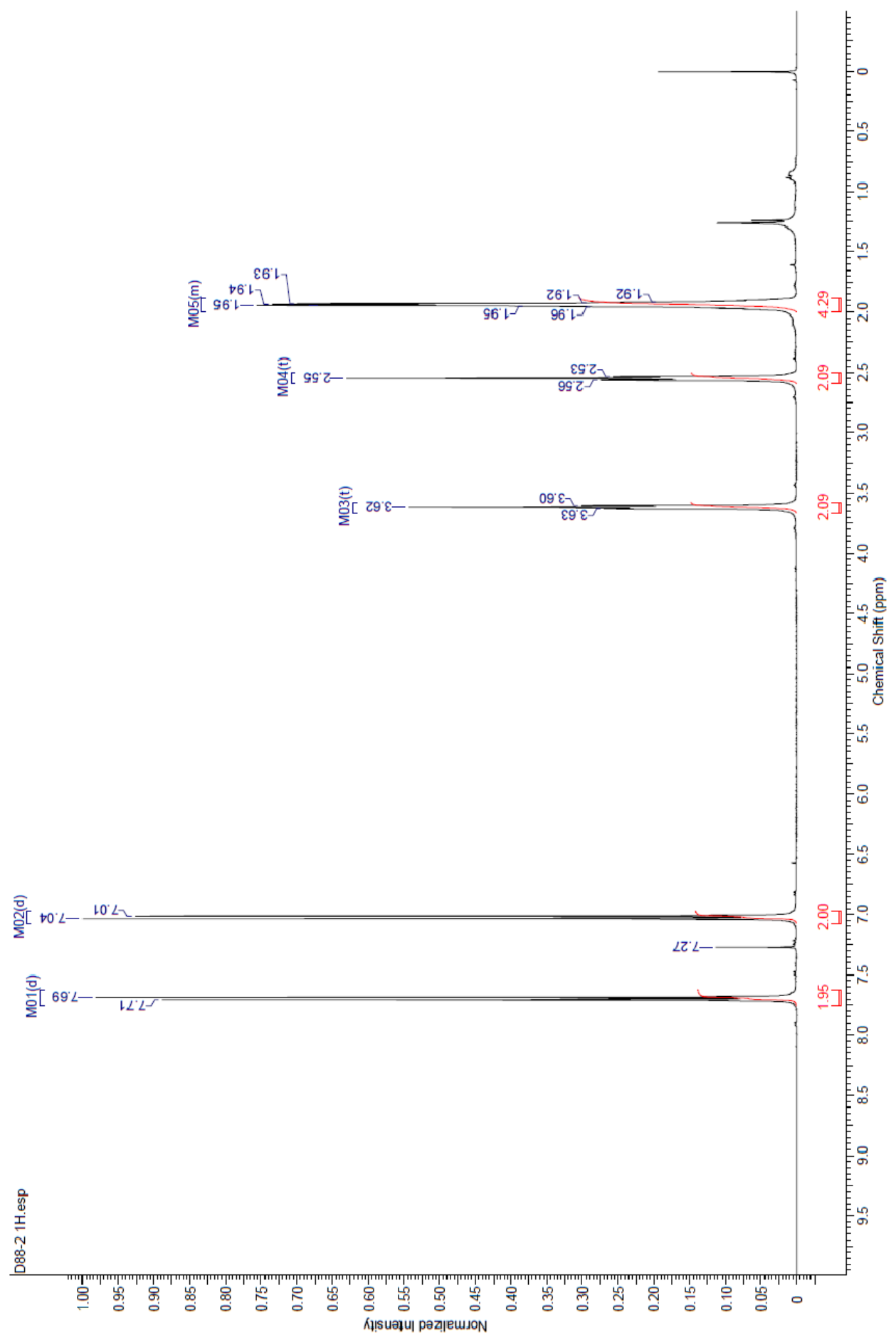


${ }^{13}$ C NMR

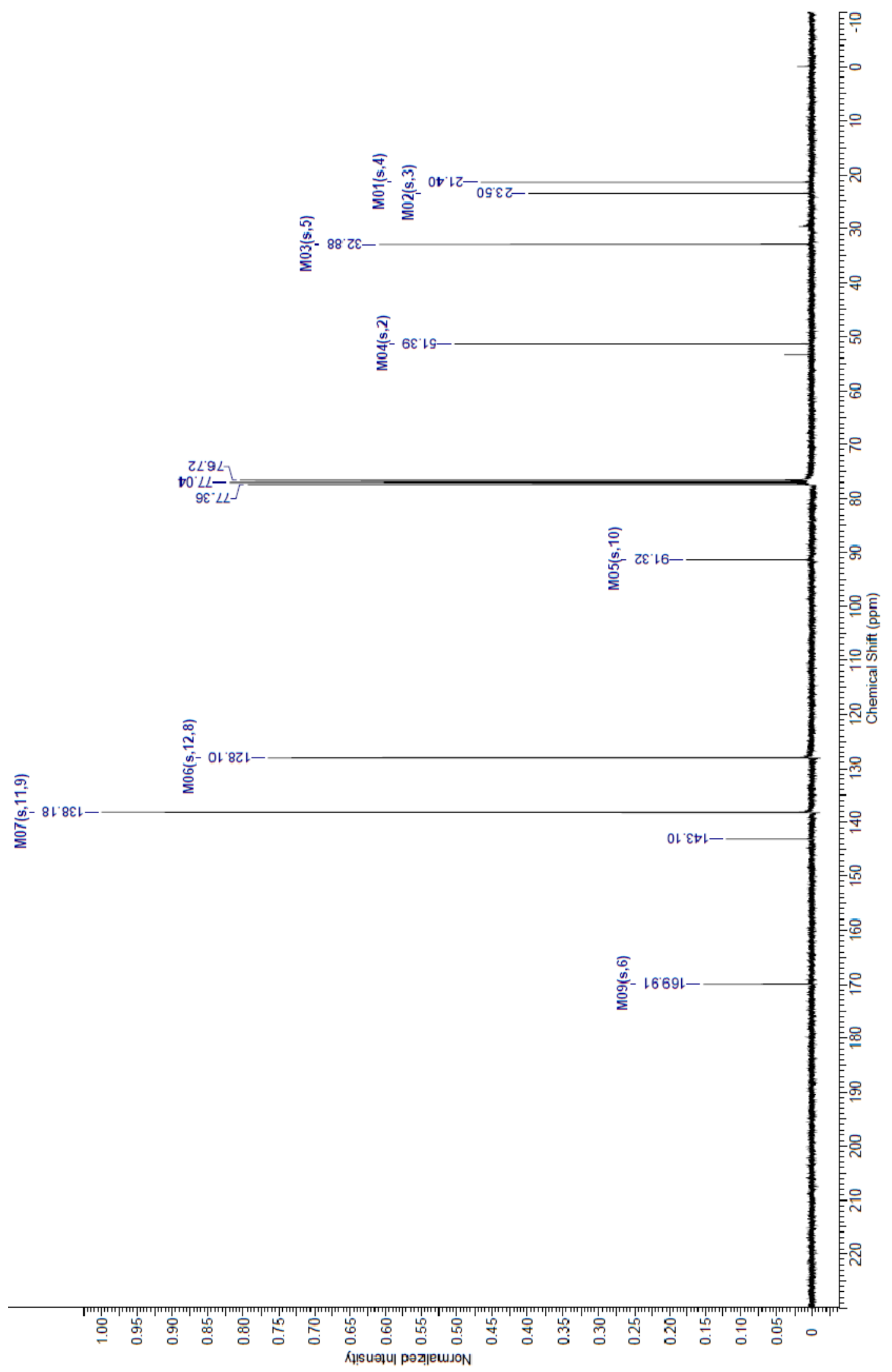




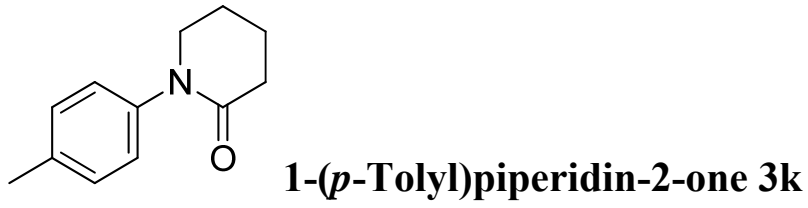

${ }^{1}$ H NMR

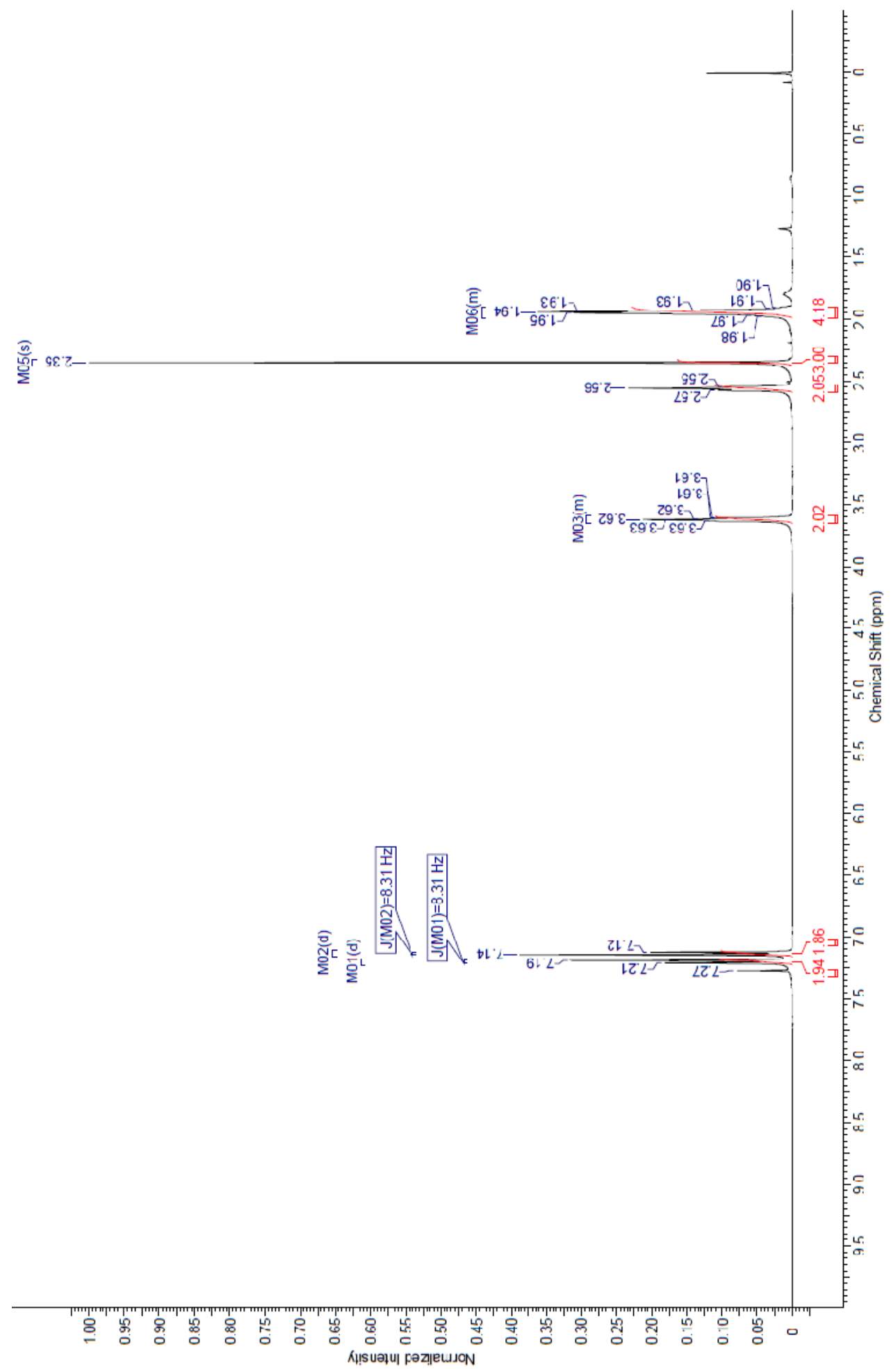


${ }^{13}$ C NMR

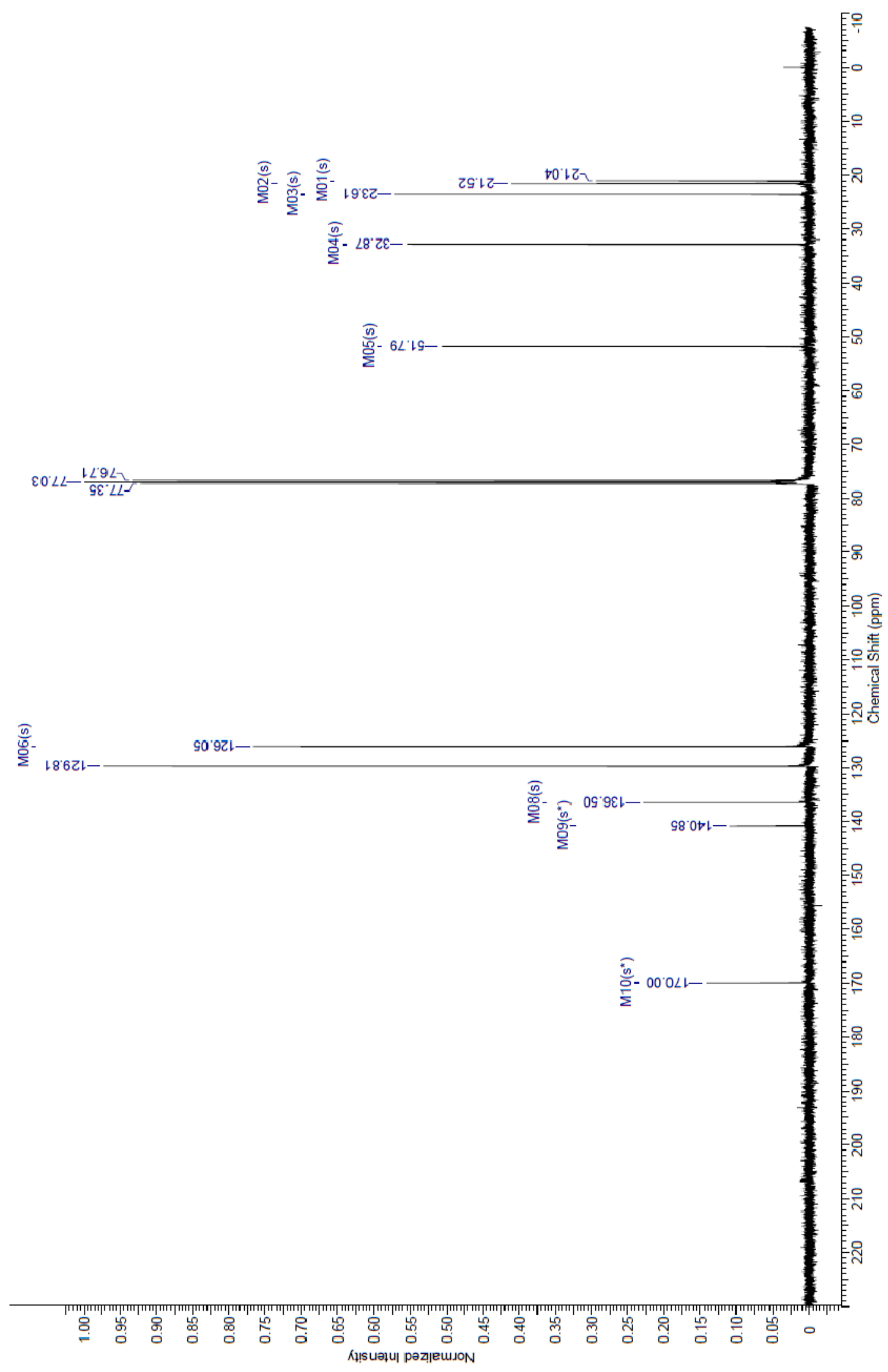


4-Phenylpiperidin-2-one 31

\section{${ }^{1}$ H NMR}
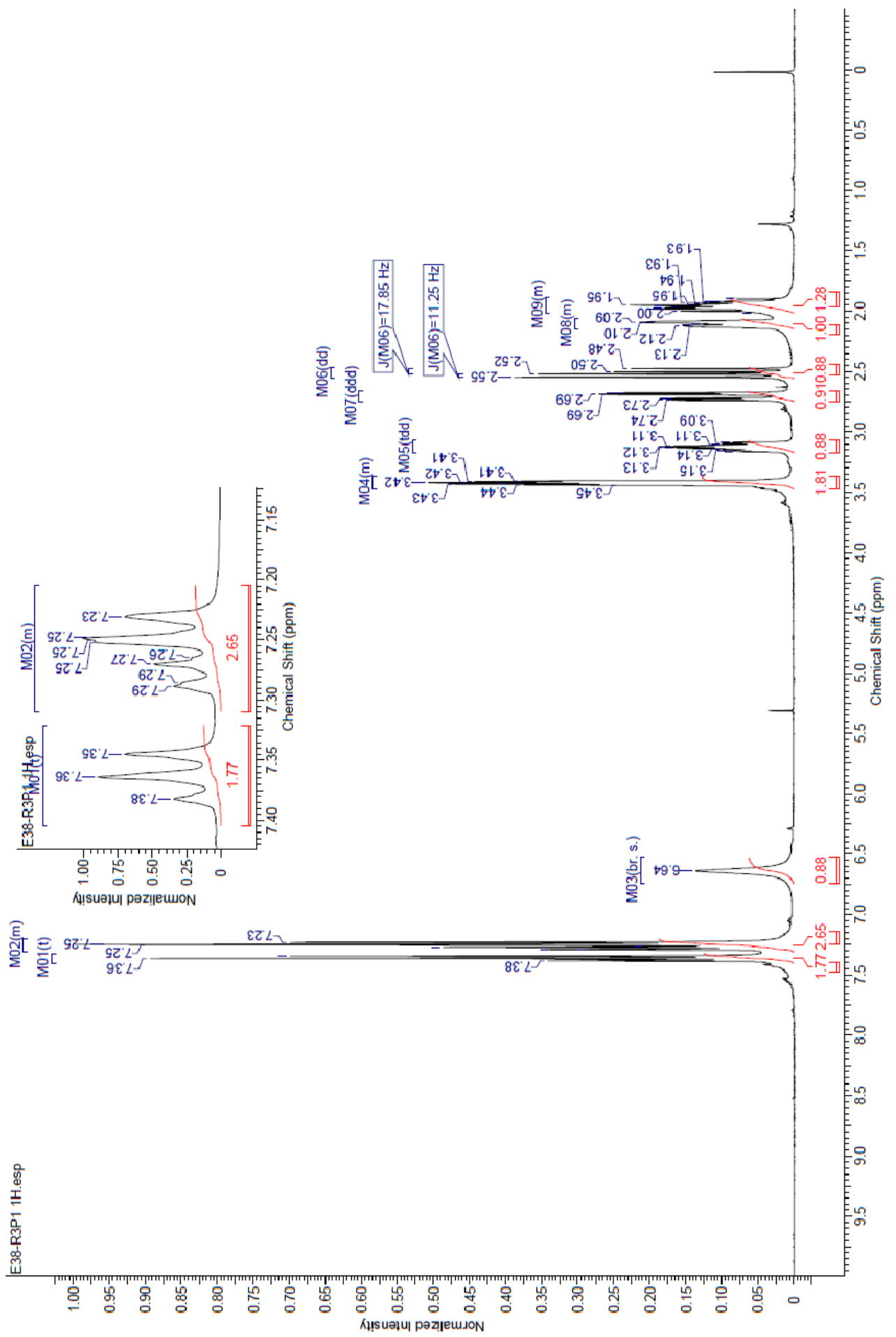
${ }^{13}$ C NMR

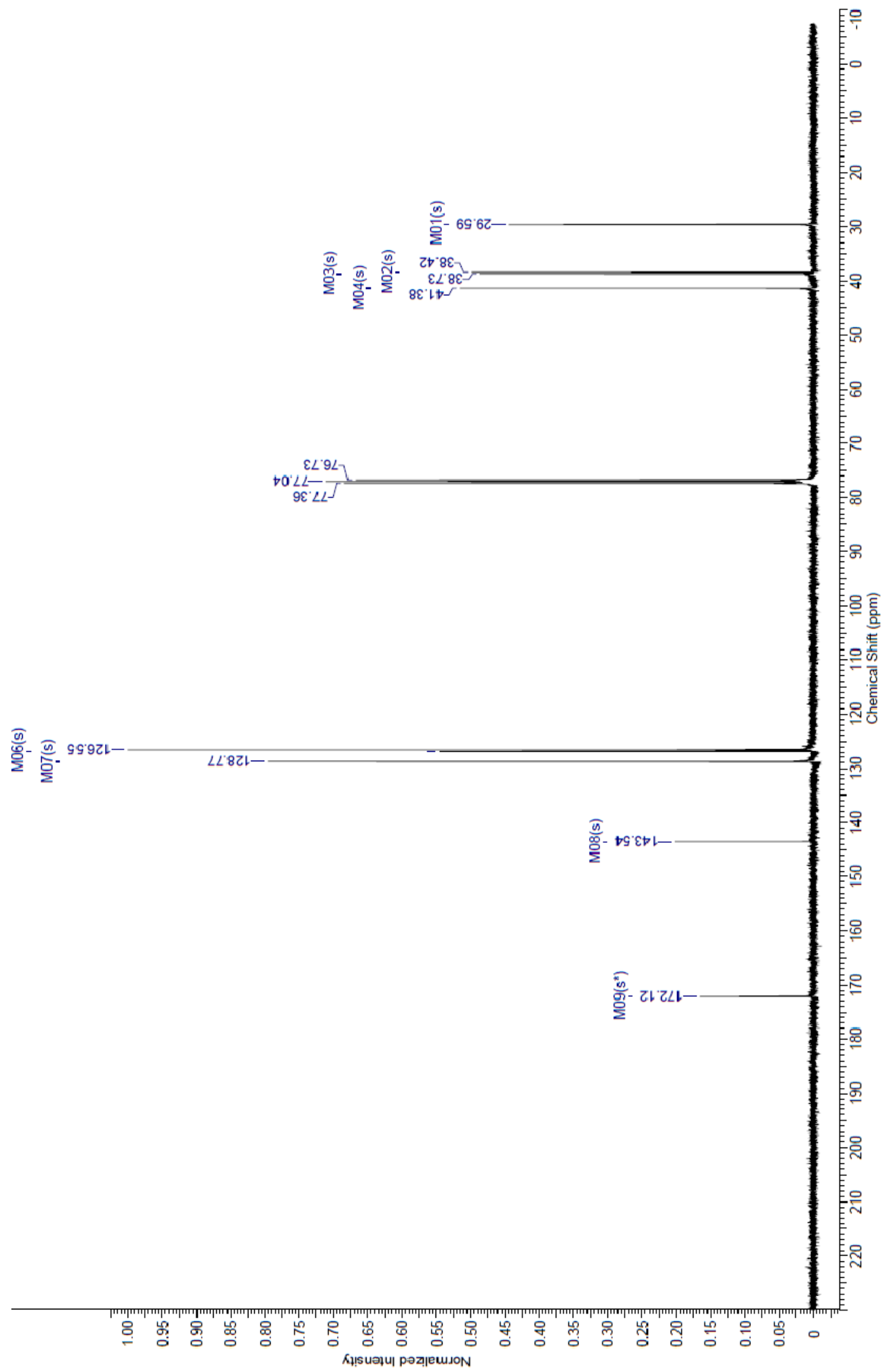


(R)-1-(1-Phenylethyl)piperidin-2-one 3m

\section{${ }^{1}$ H NMR}

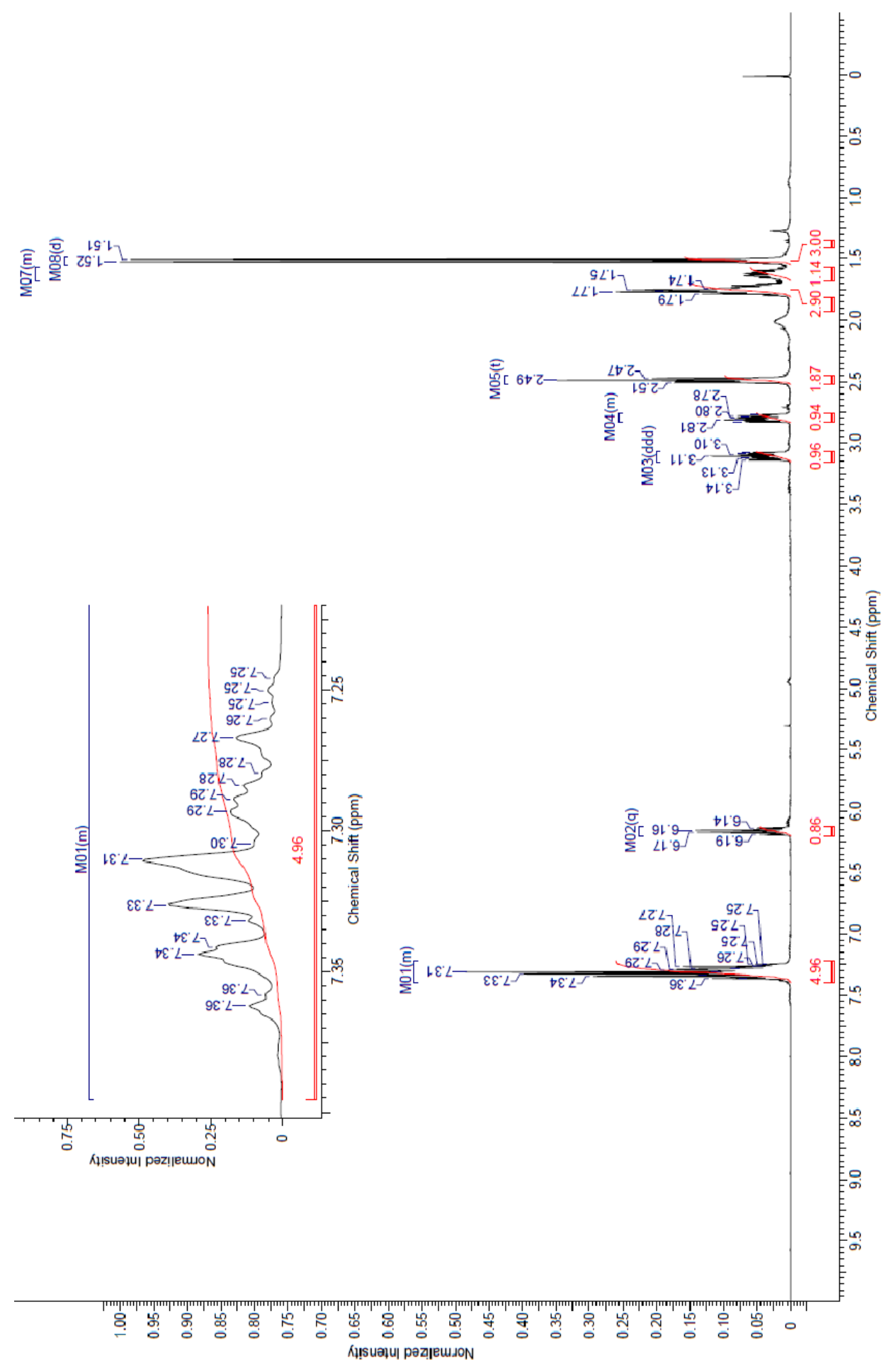


${ }^{13}$ C NMR

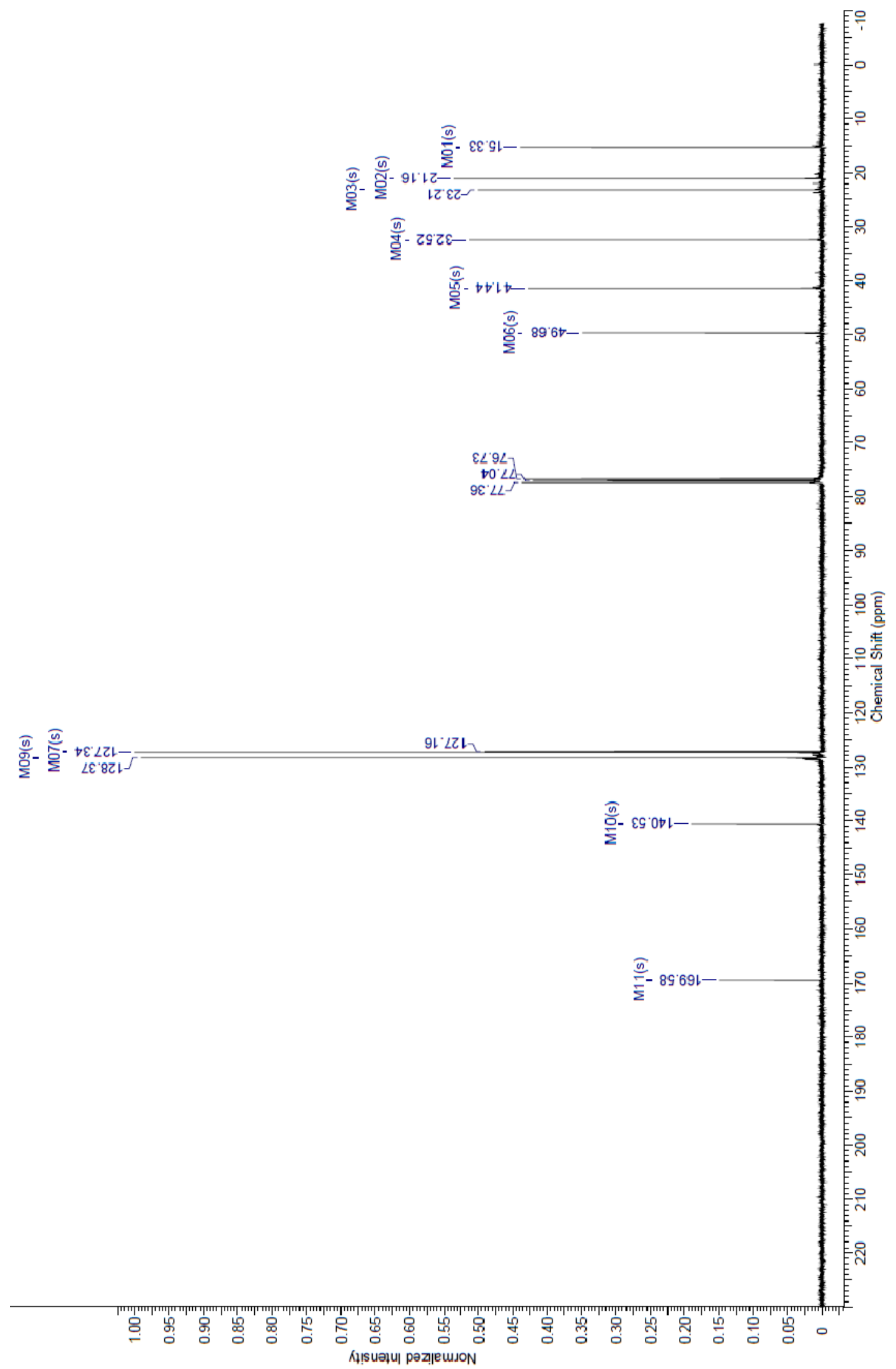


<smiles>COc1ccc(CN2CC(C)CCC2=O)cc1</smiles>

(S)-1-(4-Methoxybenzyl)-5-methylpiperidin-2-one $3 n^{\alpha}$

\section{${ }^{1}$ H NMR}

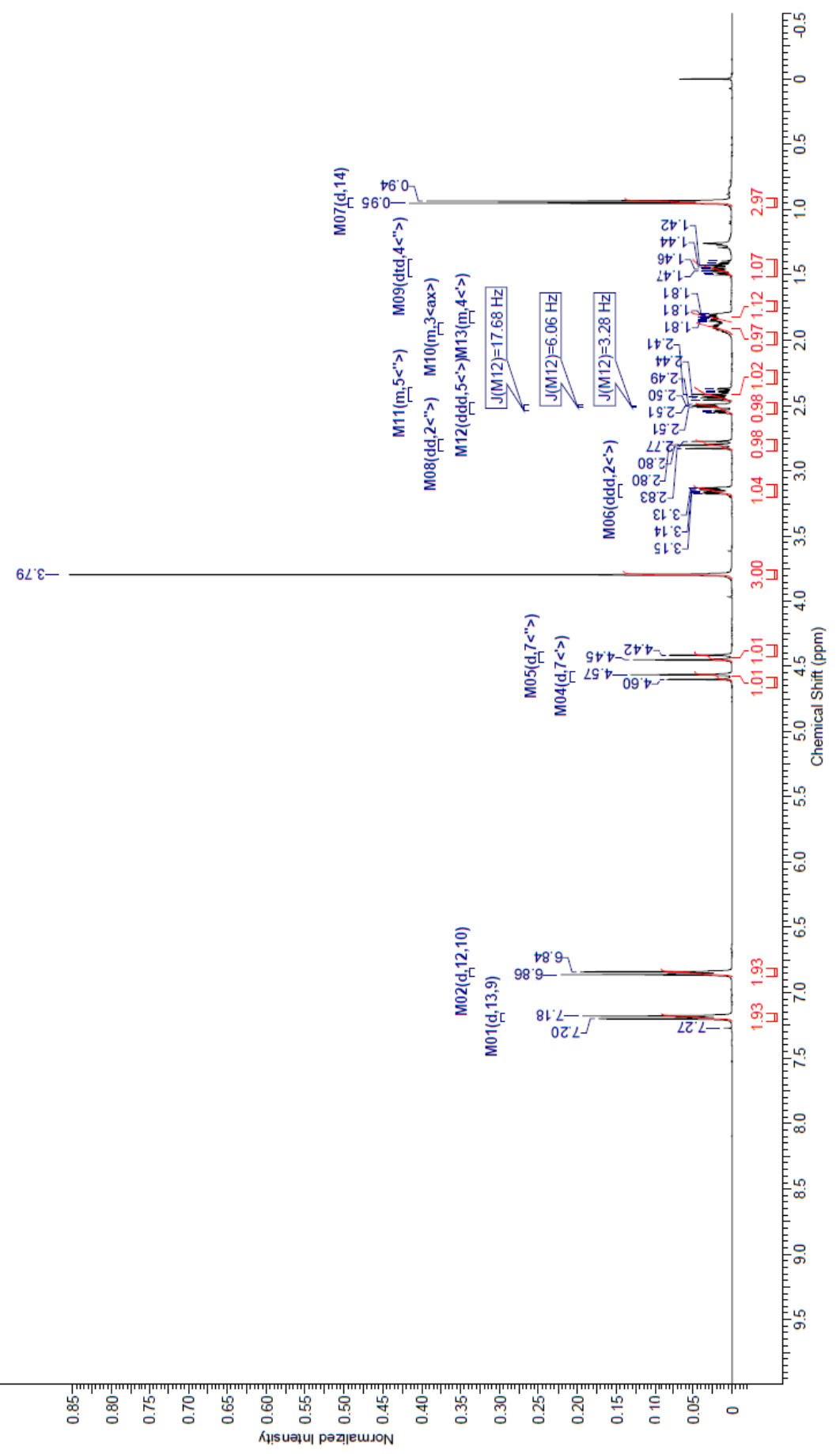


${ }^{13}$ C NMR

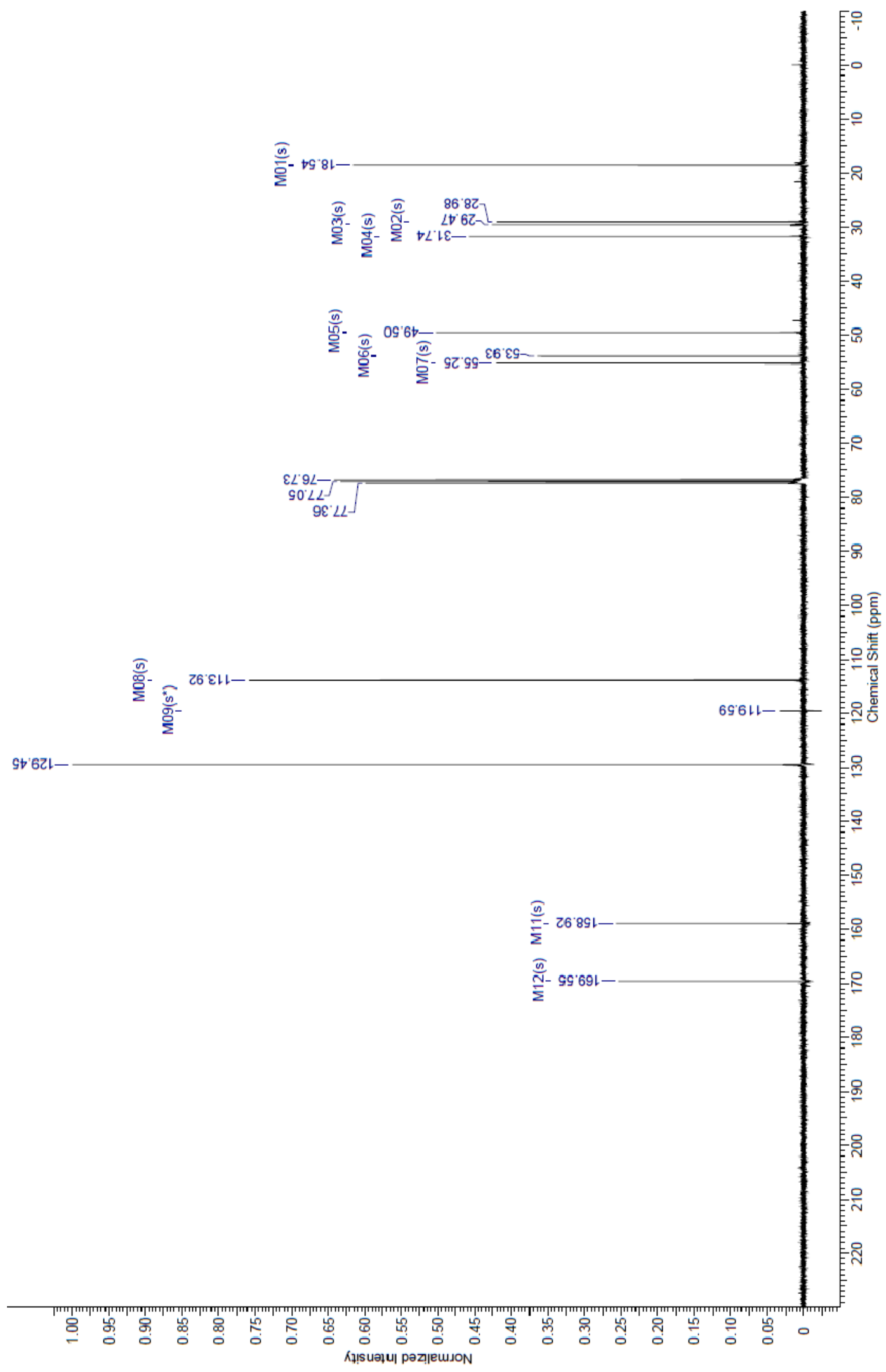


<smiles>COc1ccc(CN2CCCC(C)C2=O)cc1</smiles>

(S)-1-(4-Methoxybenzyl)-3-methylpiperidin-2-one $3 n^{\beta}$

${ }^{1}$ H NMR

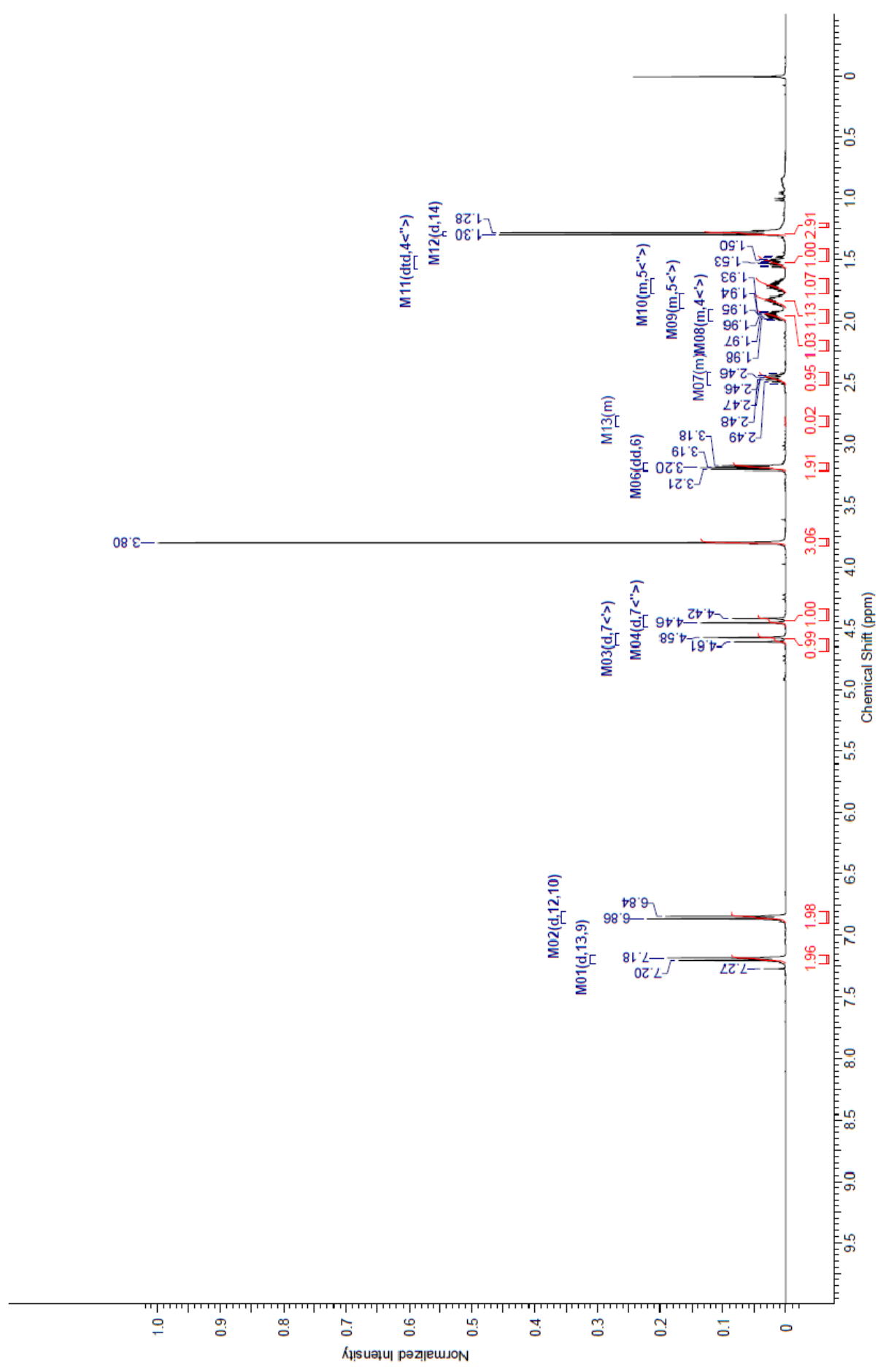


${ }^{13}$ C NMR

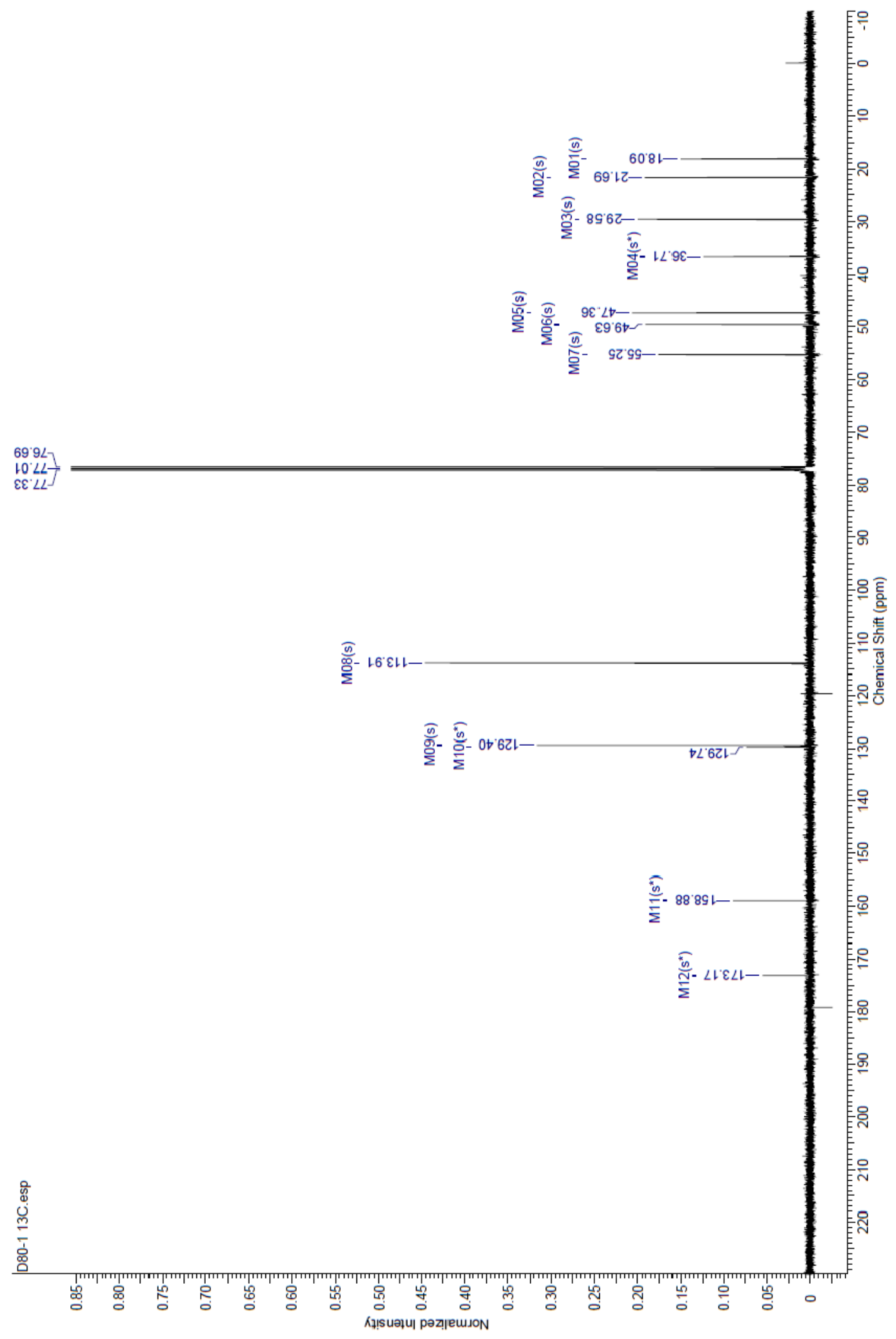


<smiles>COc1ccc(CN2C[C@H](C)O[C@H](C)C2=O)cc1</smiles>

(2R,6R)-4-(4-Methoxybenzyl)-2,6-dimethylmorpholin-3-one 30

\section{${ }^{1} \mathrm{H}$ NMR}

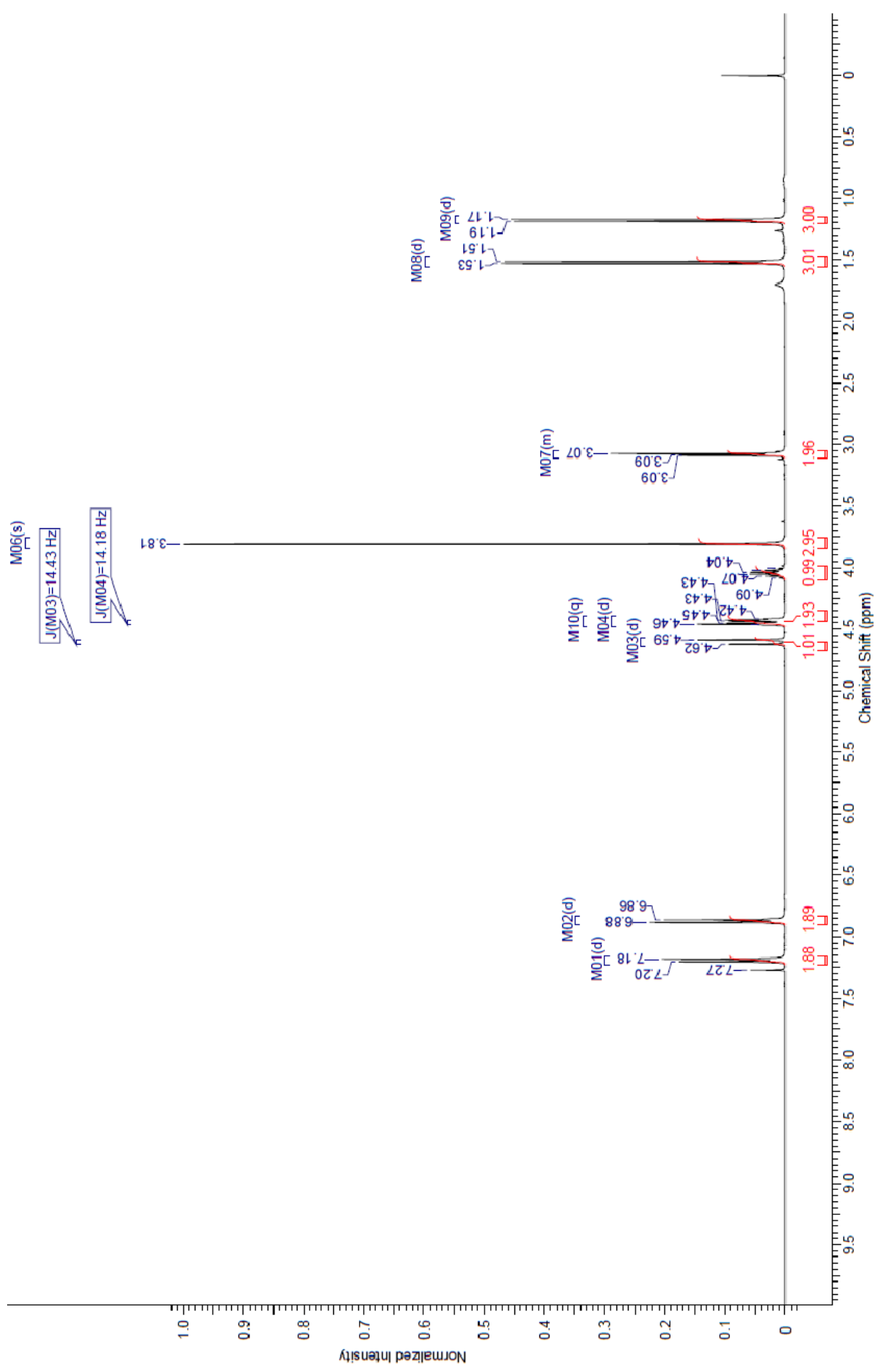


${ }^{13}$ C NMR

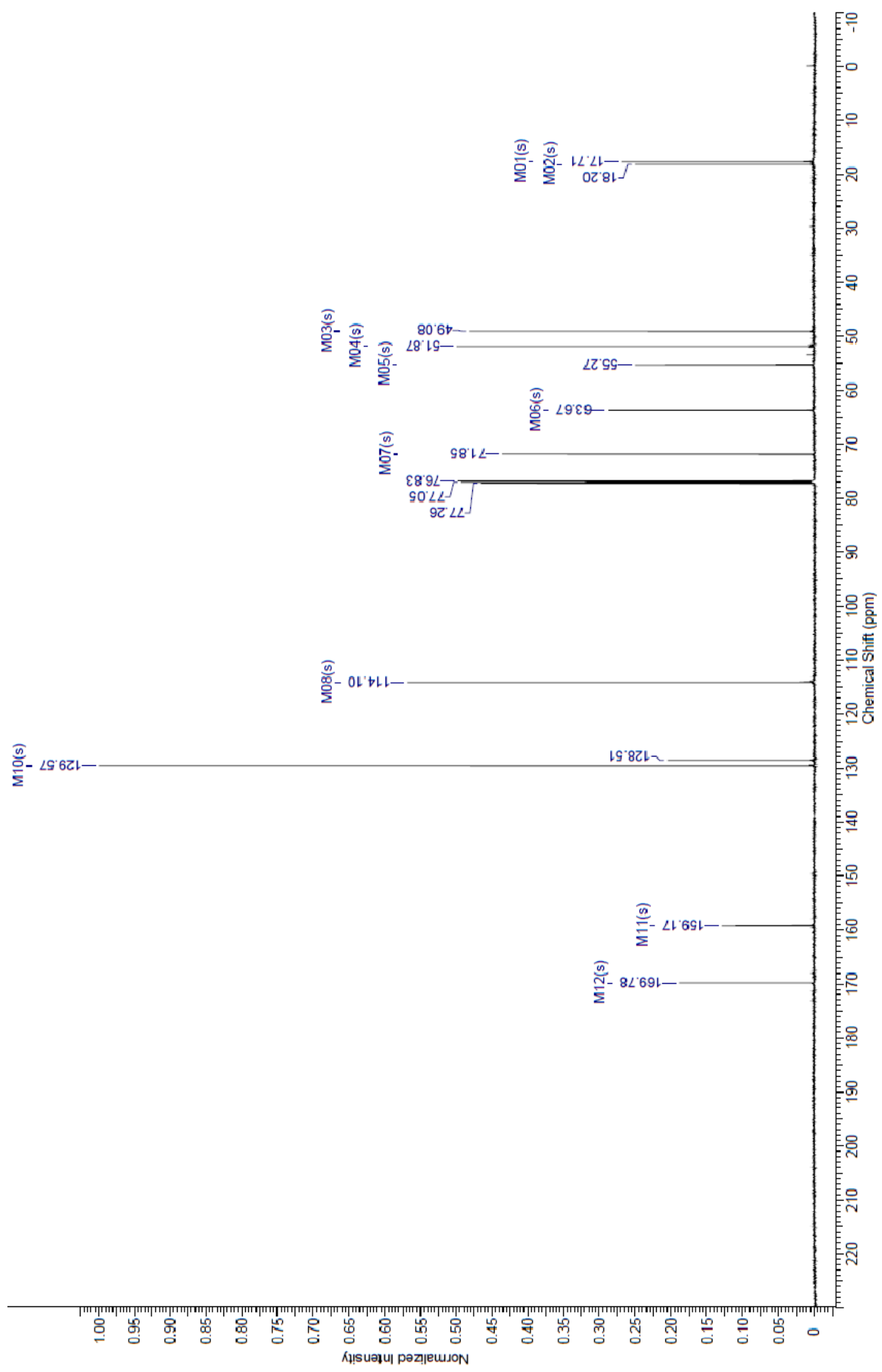


<smiles>CCOC(=O)C1CCC(=O)N1Cc1ccccc1</smiles>

(S)-Ethyl 1-benzyl-5-oxopyrrolidine-2-carboxylate 3p

\section{${ }^{1}$ H NMR}

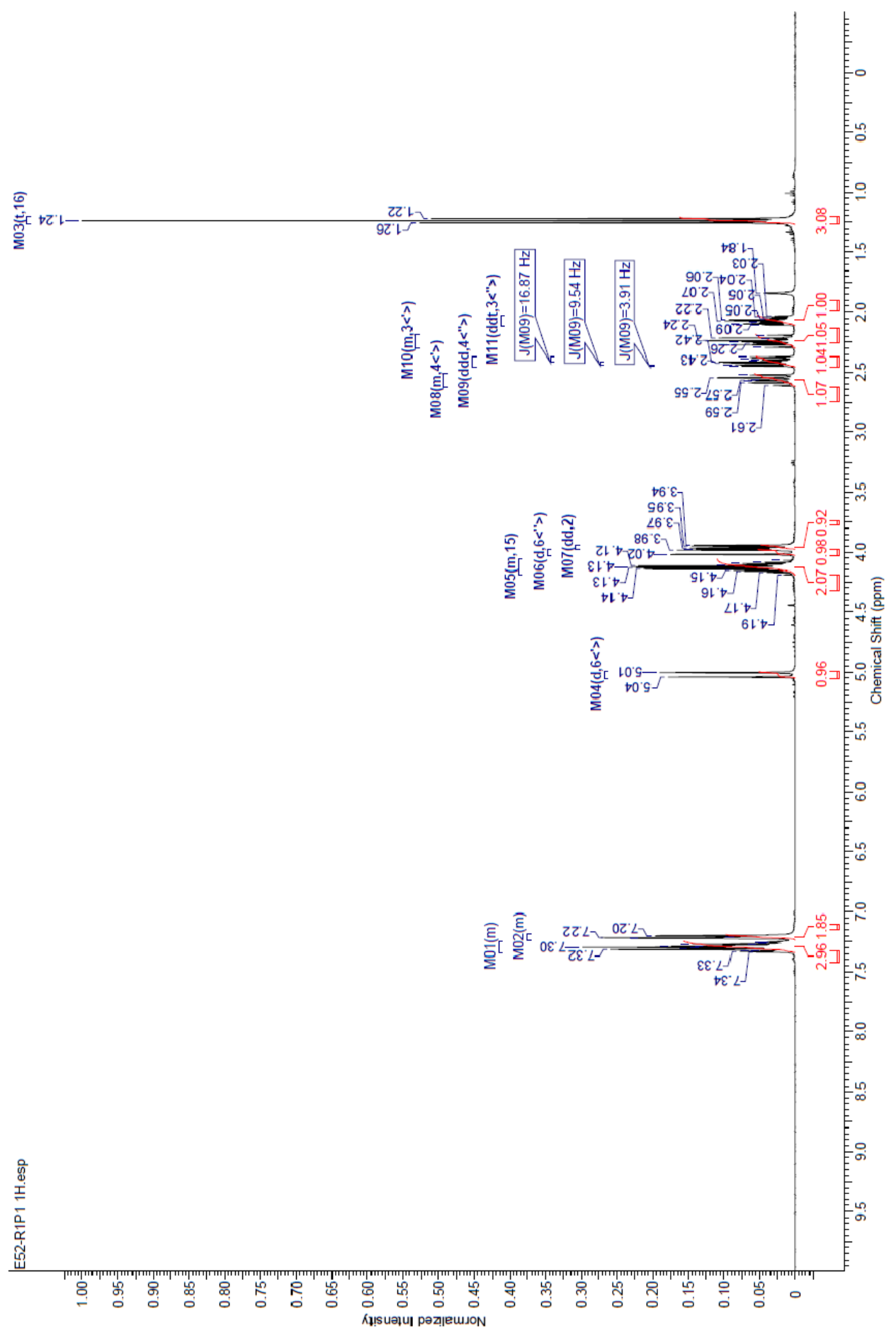


${ }^{13}$ C NMR

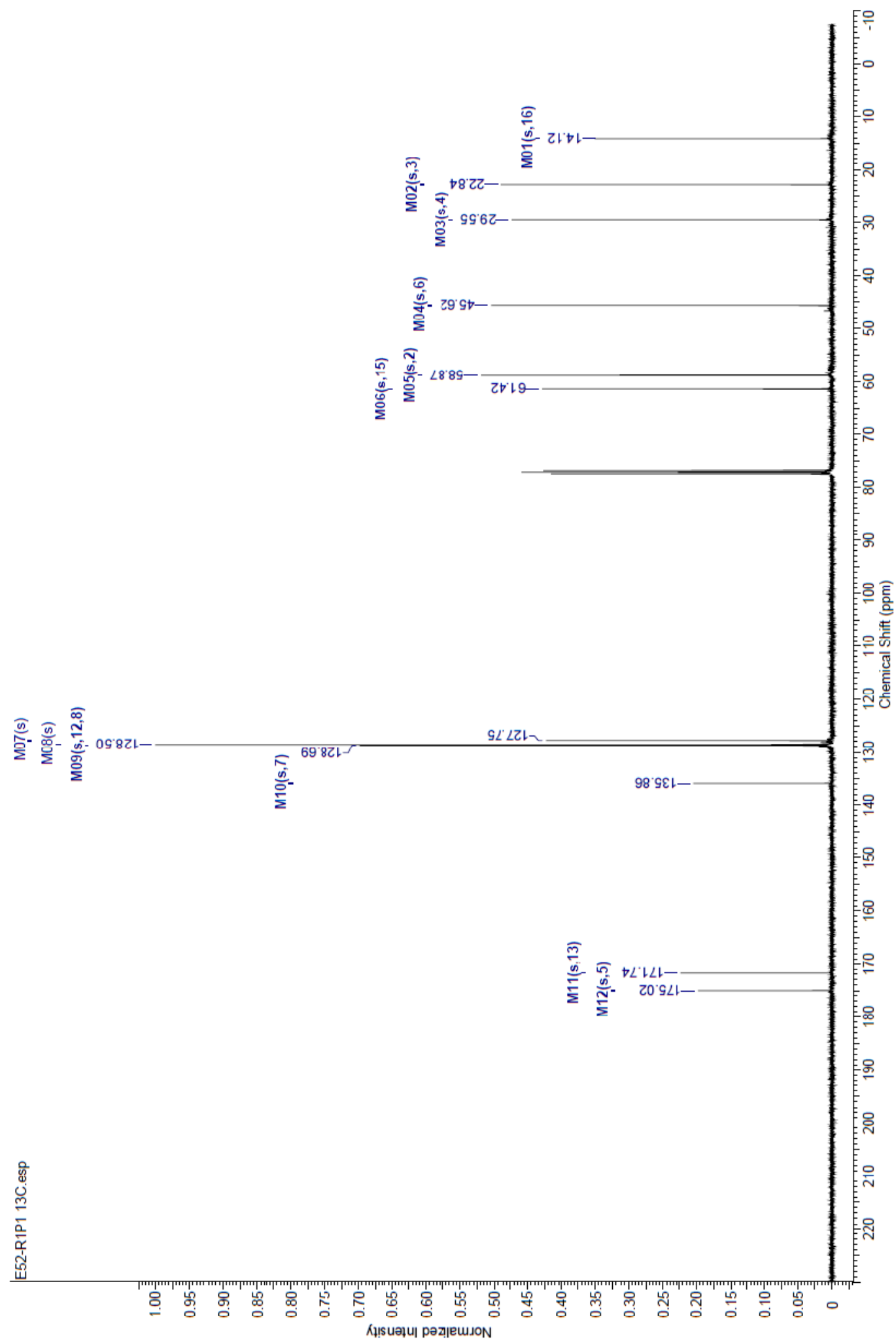




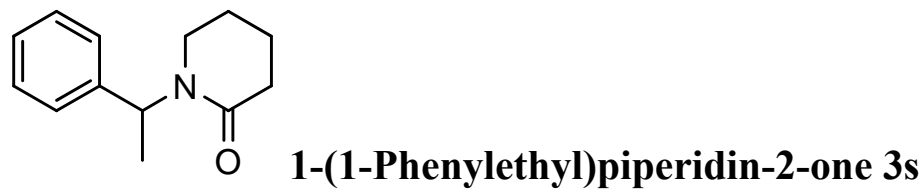

\section{${ }^{1}$ H NMR}

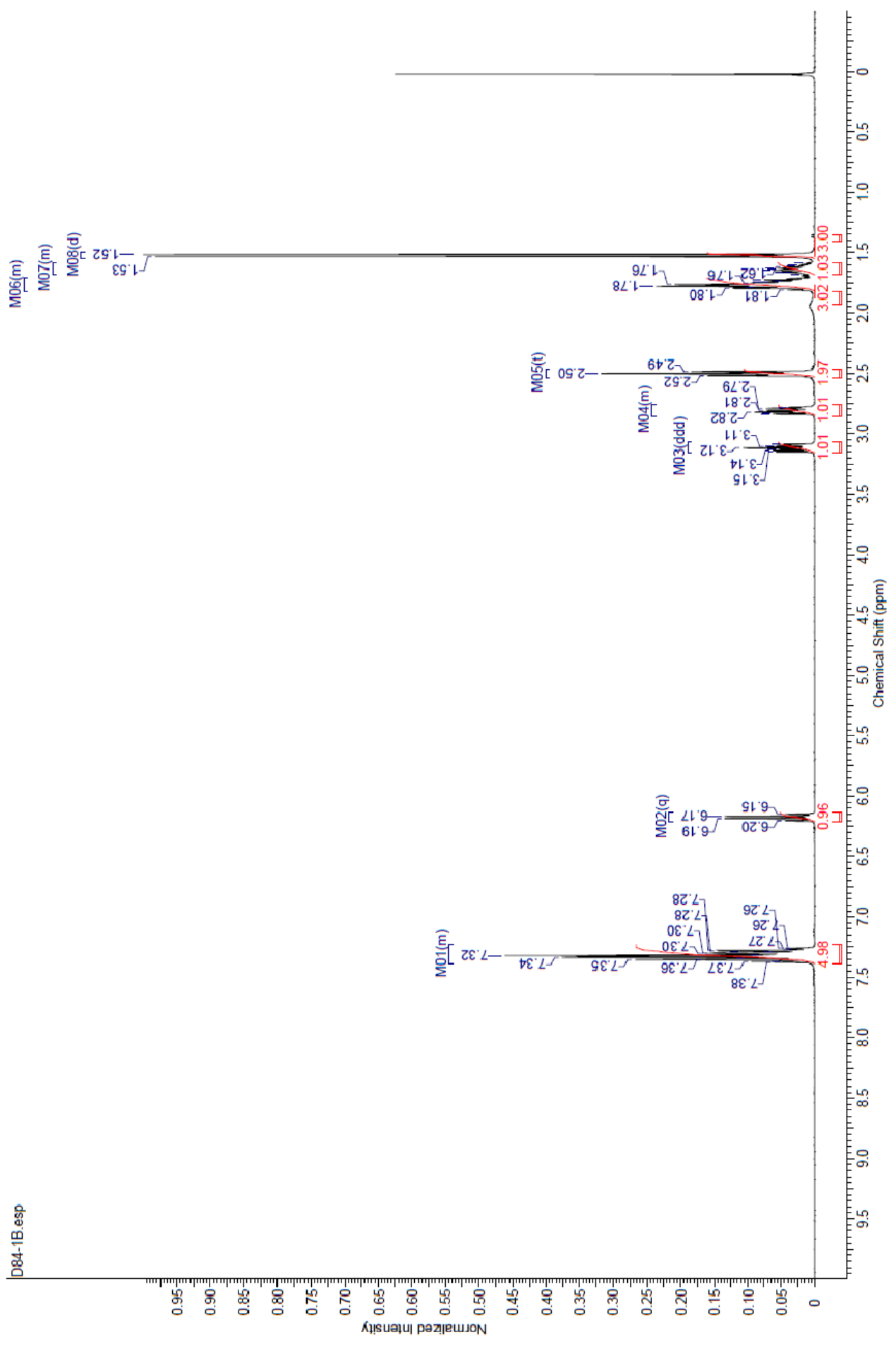




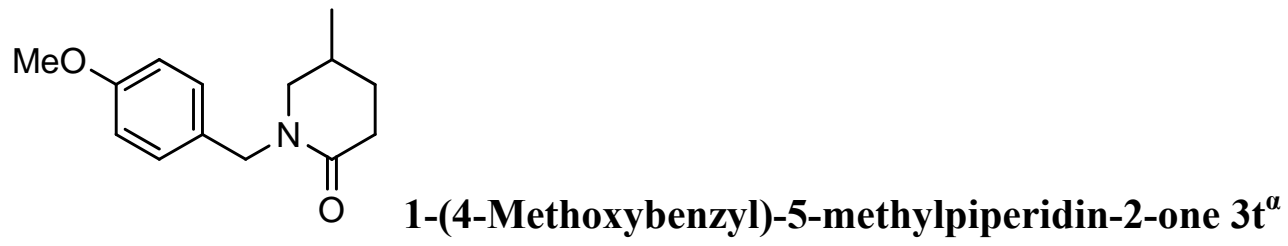

\section{${ }^{1}$ H NMR}

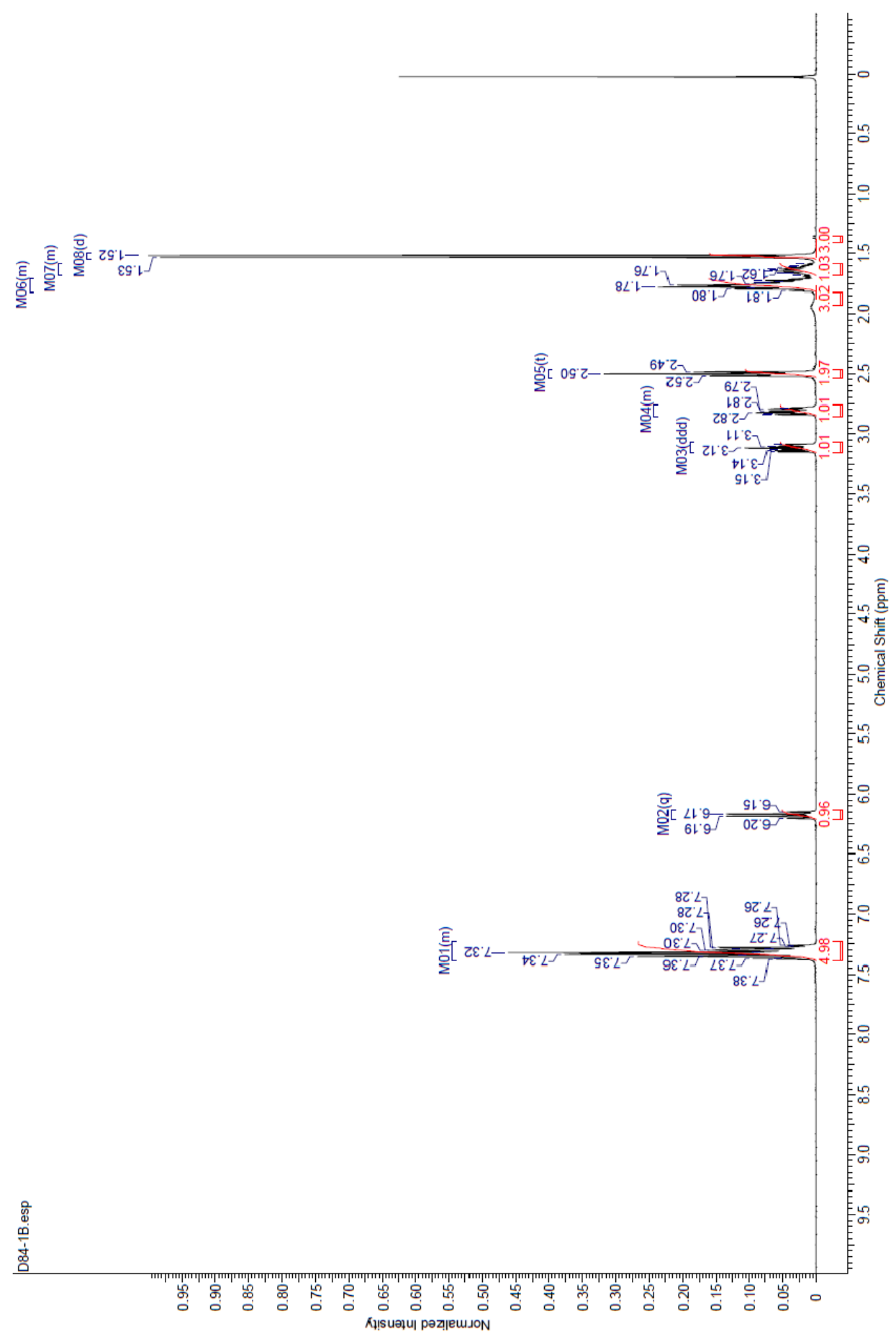


1-(4-methoxybenzyl)-3-methylpiperidin-2-one $3 \mathrm{t}^{\beta}$

\section{${ }^{1}$ H NMR}

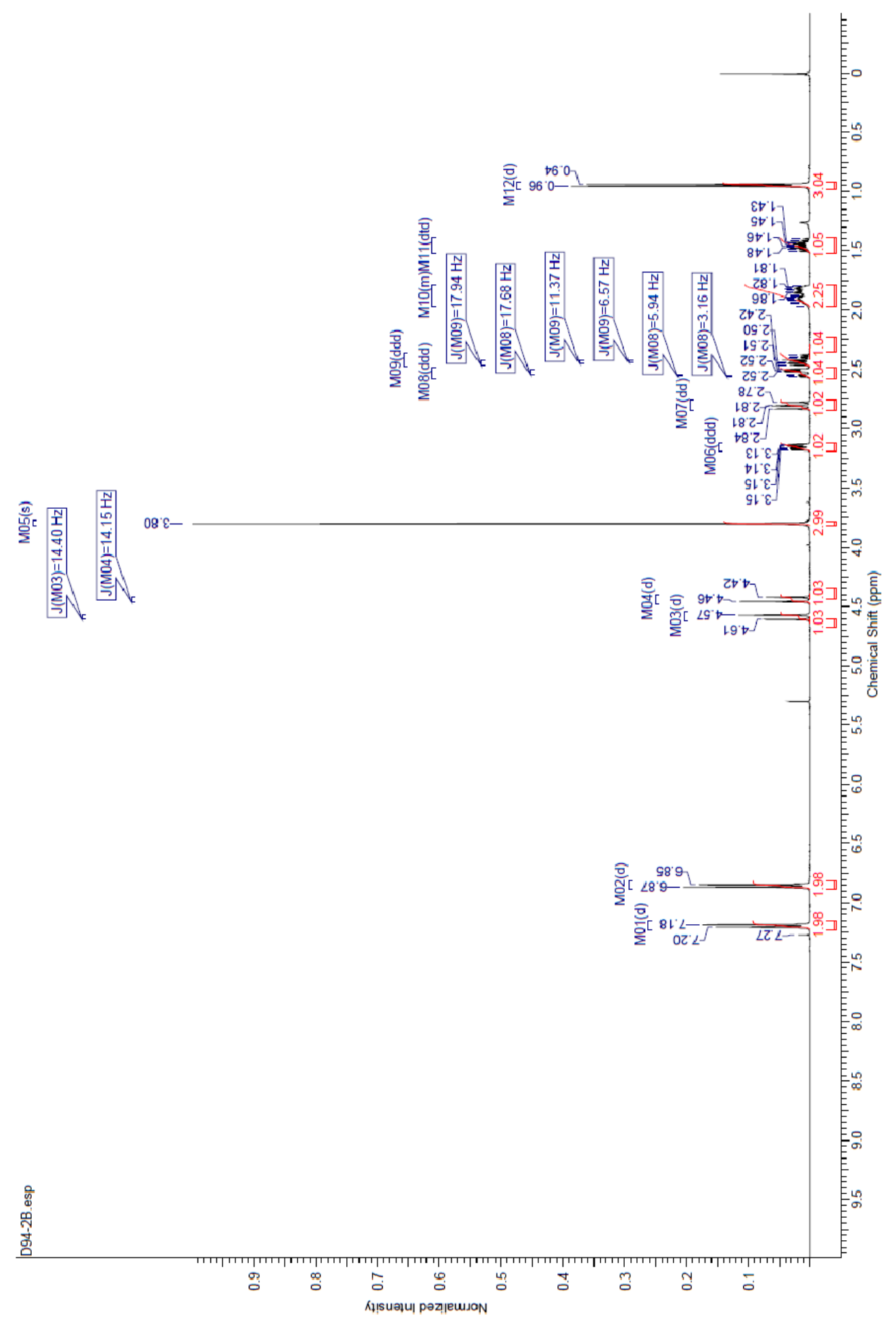


<smiles>CCOC(=O)C1CCC(=O)N1Cc1ccccc1</smiles>

Ethyl 1-benzyl-5-oxopyrrolidine-2-carboxylate 3u

\section{${ }^{1}$ H NMR}

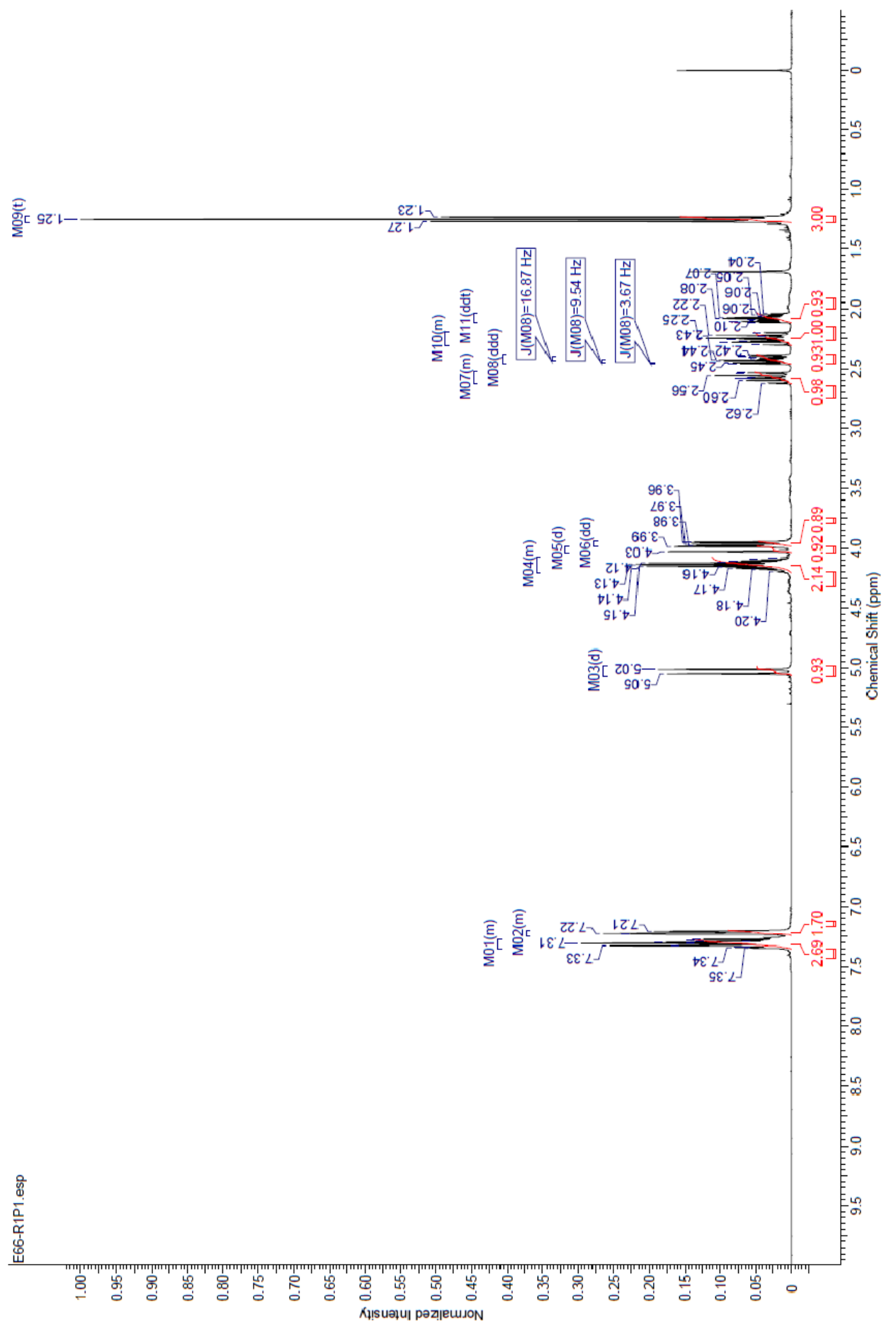


<smiles>Cc1nc2n(c(=O)c1CCN1CCC(c3noc4cc(F)ccc34)CC1=O)CCCC2</smiles>

\section{${ }^{1}$ H NMR}

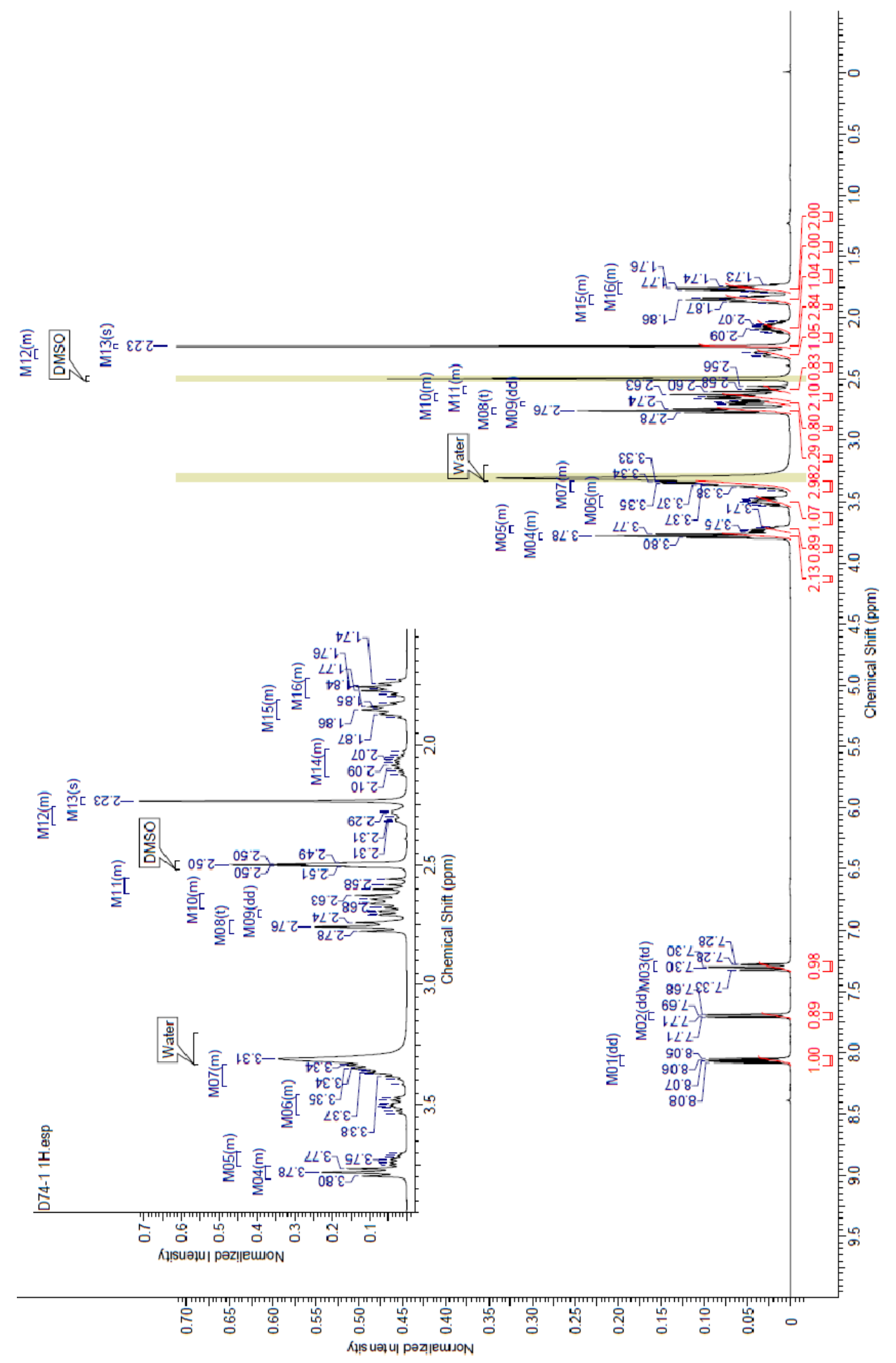


${ }^{13}$ C NMR

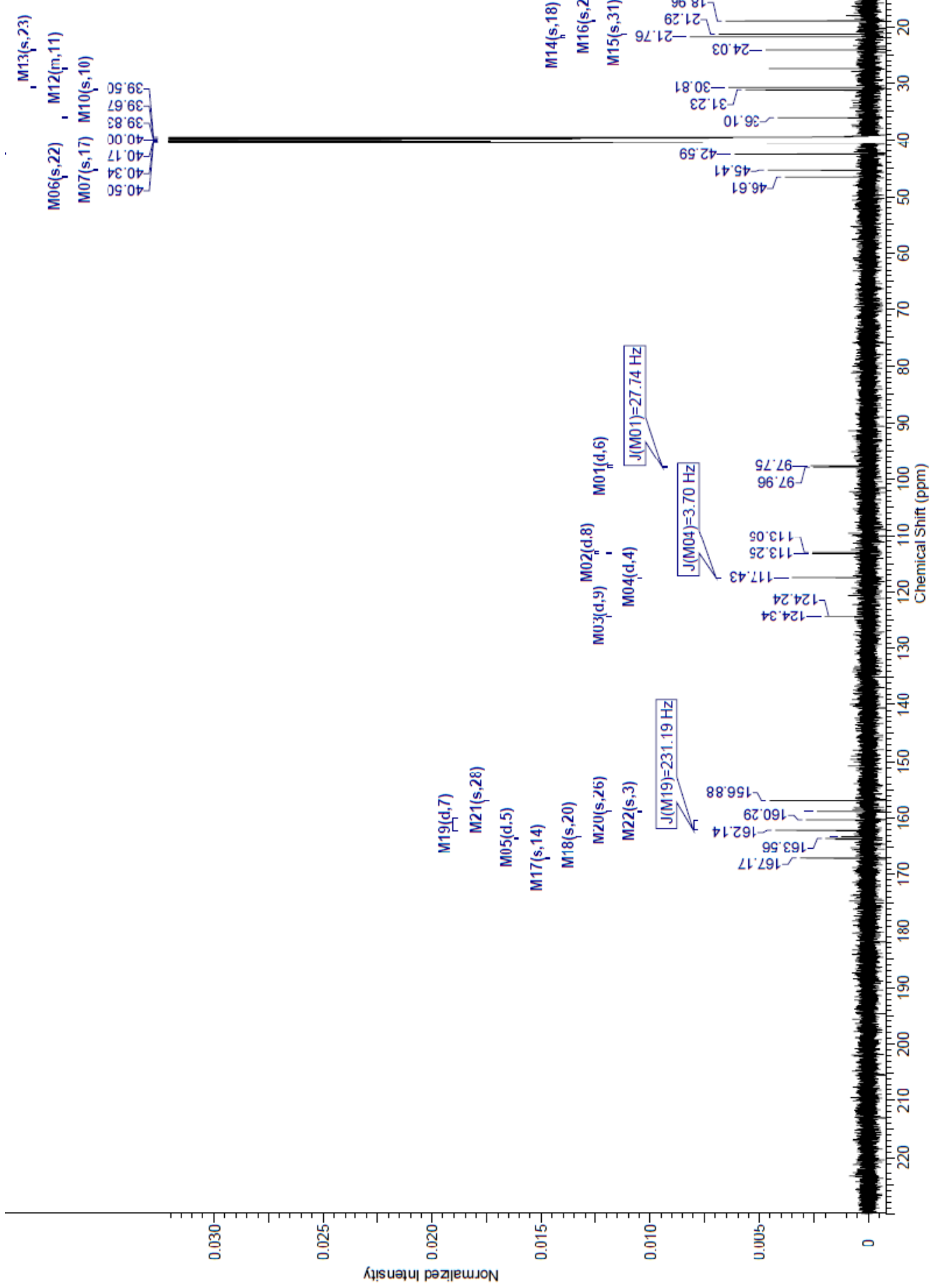




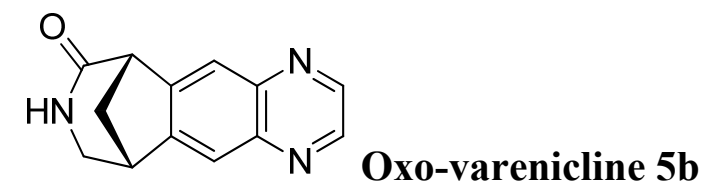

\section{${ }^{1}$ H NMR}

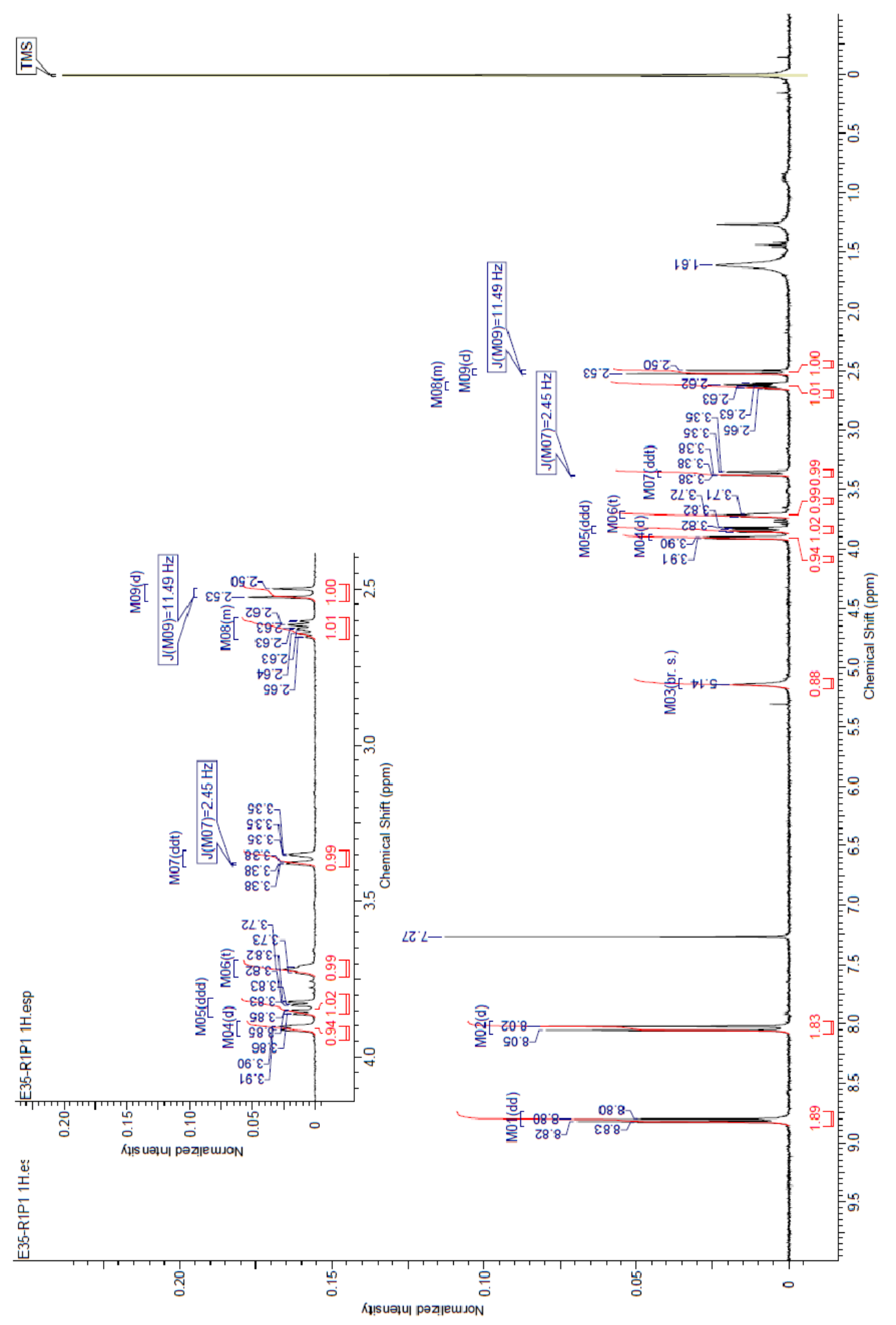




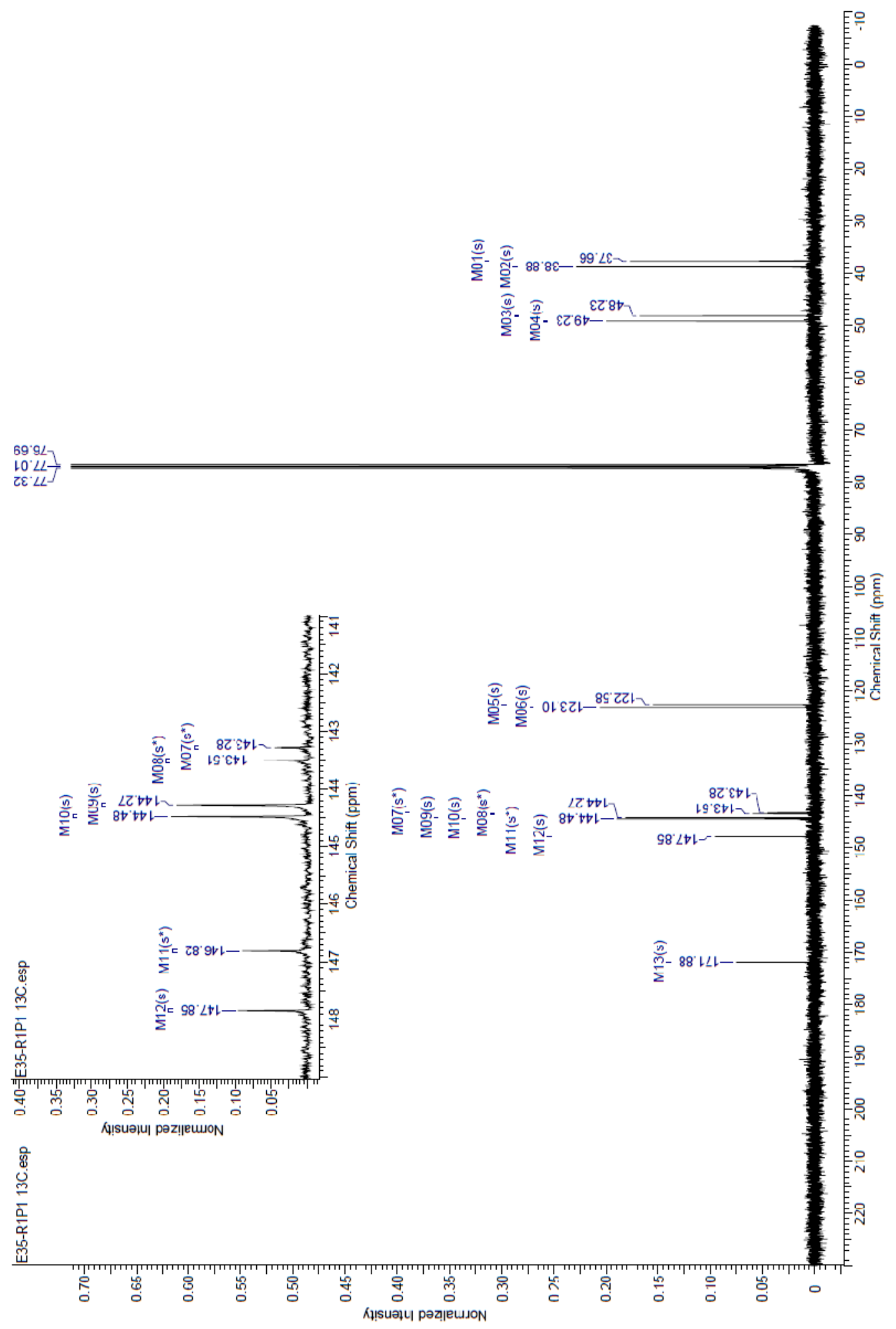


<smiles>COc1ccc2c(c1)CCC(c1ccccc1)=C2c1ccc(OCCN2CCCC2=O)cc1</smiles>

\section{${ }^{1}$ H NMR}

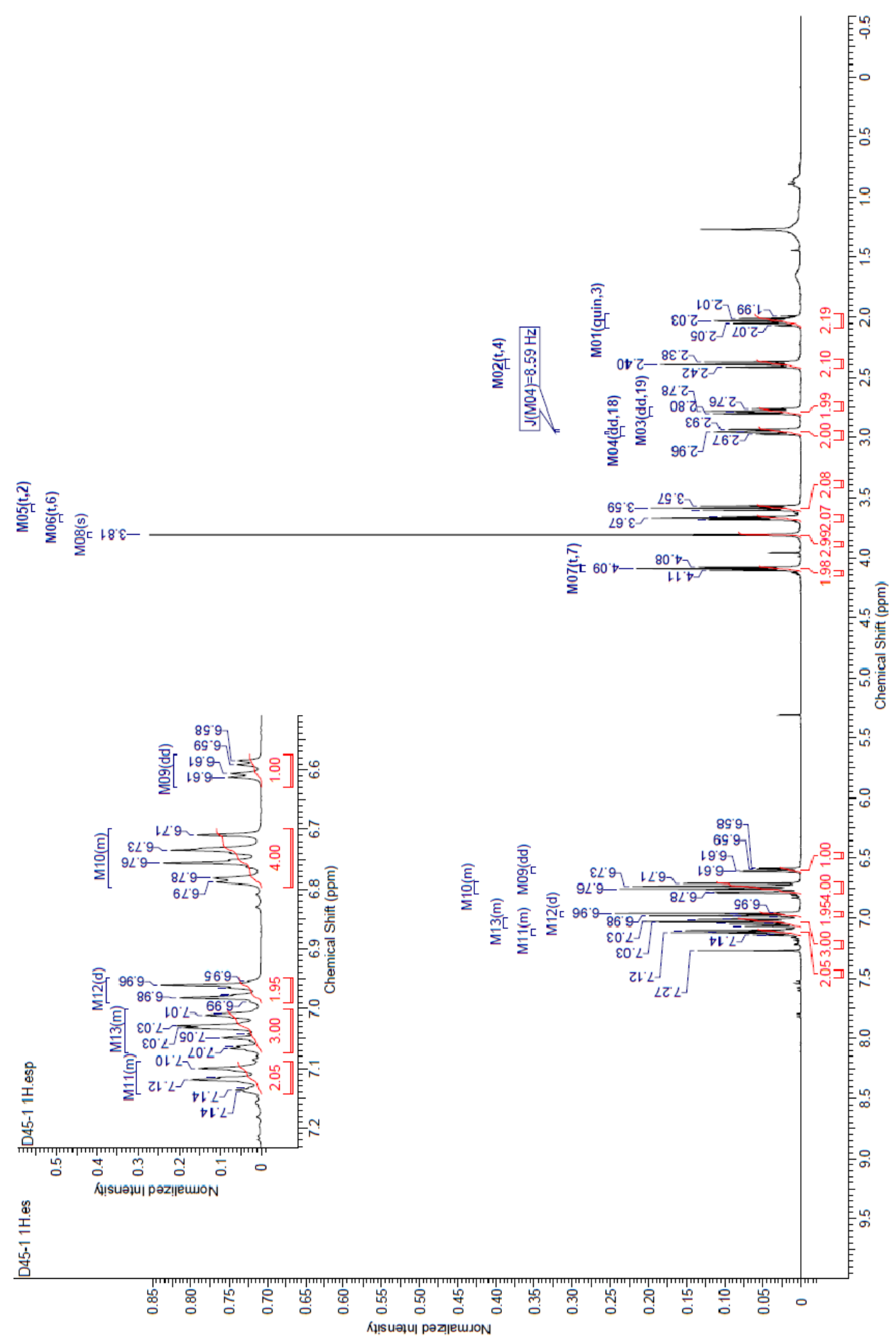




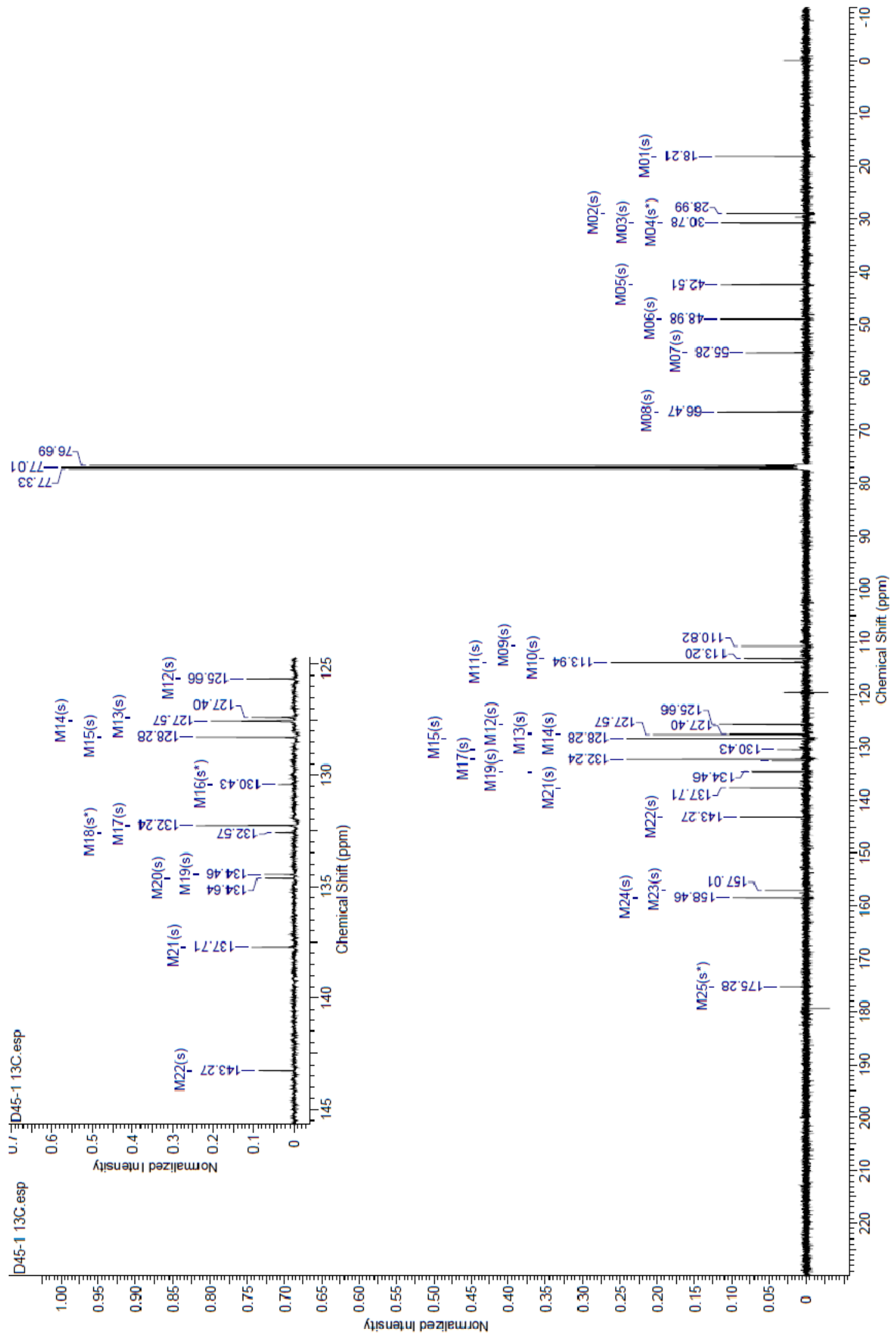


<smiles>Cc1ccc(C(=CCN2CCCC2=O)c2cccc(C=CC(=O)O)n2)cc1</smiles>

\section{${ }^{1}$ H NMR}

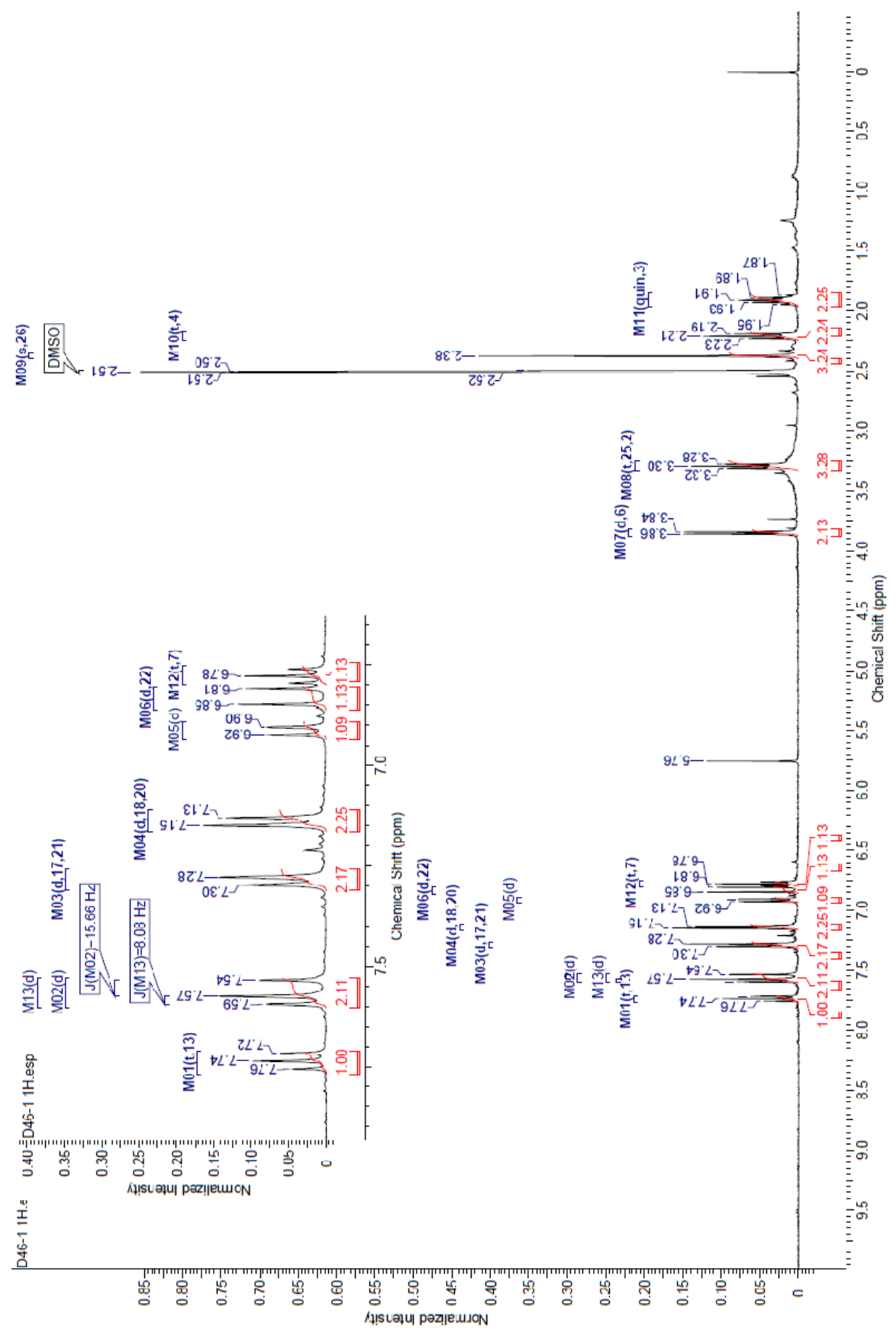




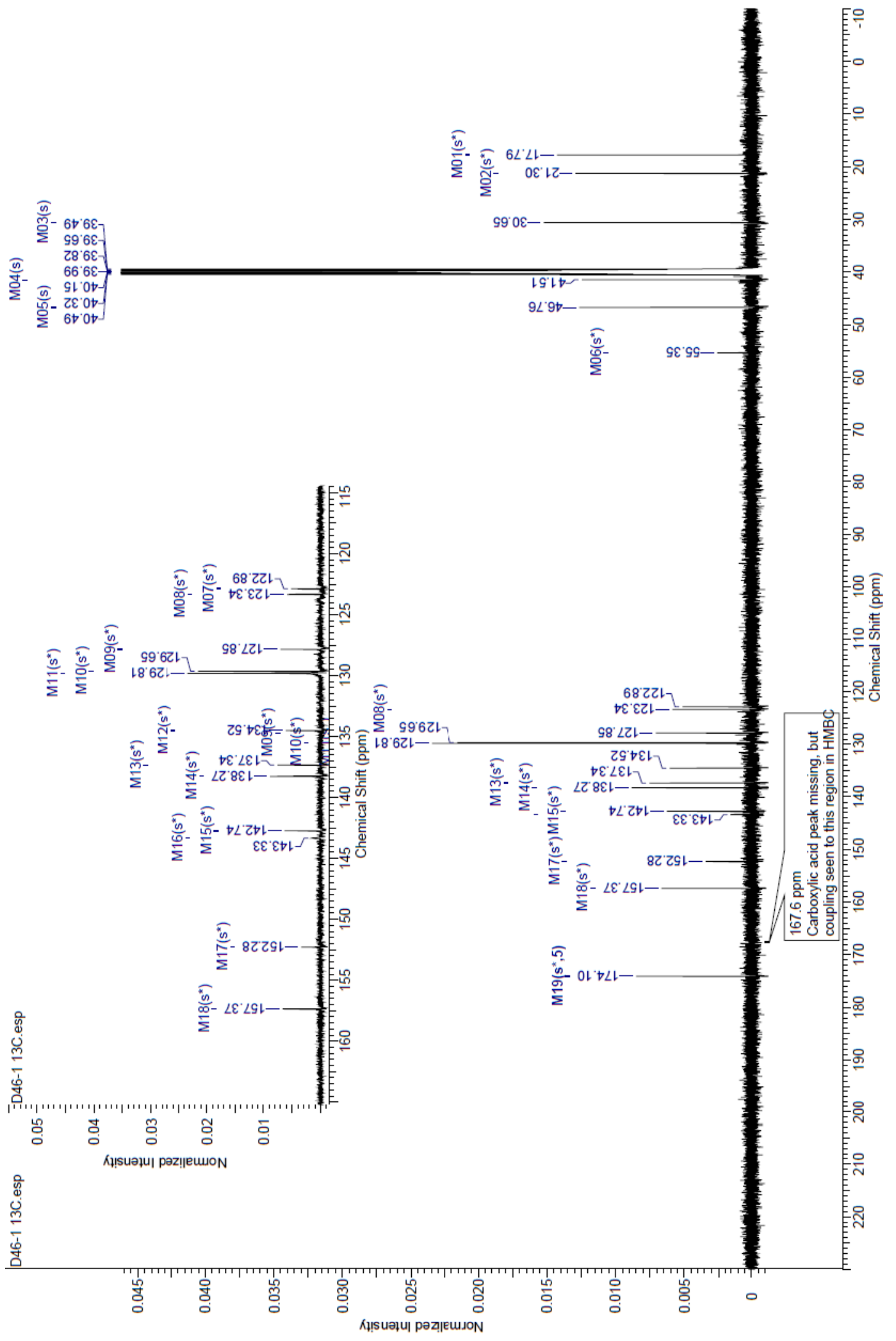


<smiles>CCCc1nc(C)c2c(=O)[nH]c(-c3cc(S(=O)(=O)N4CCN(CC)C(=O)C4)ccc3OCC)nn12</smiles>

\section{${ }^{1}$ H NMR}

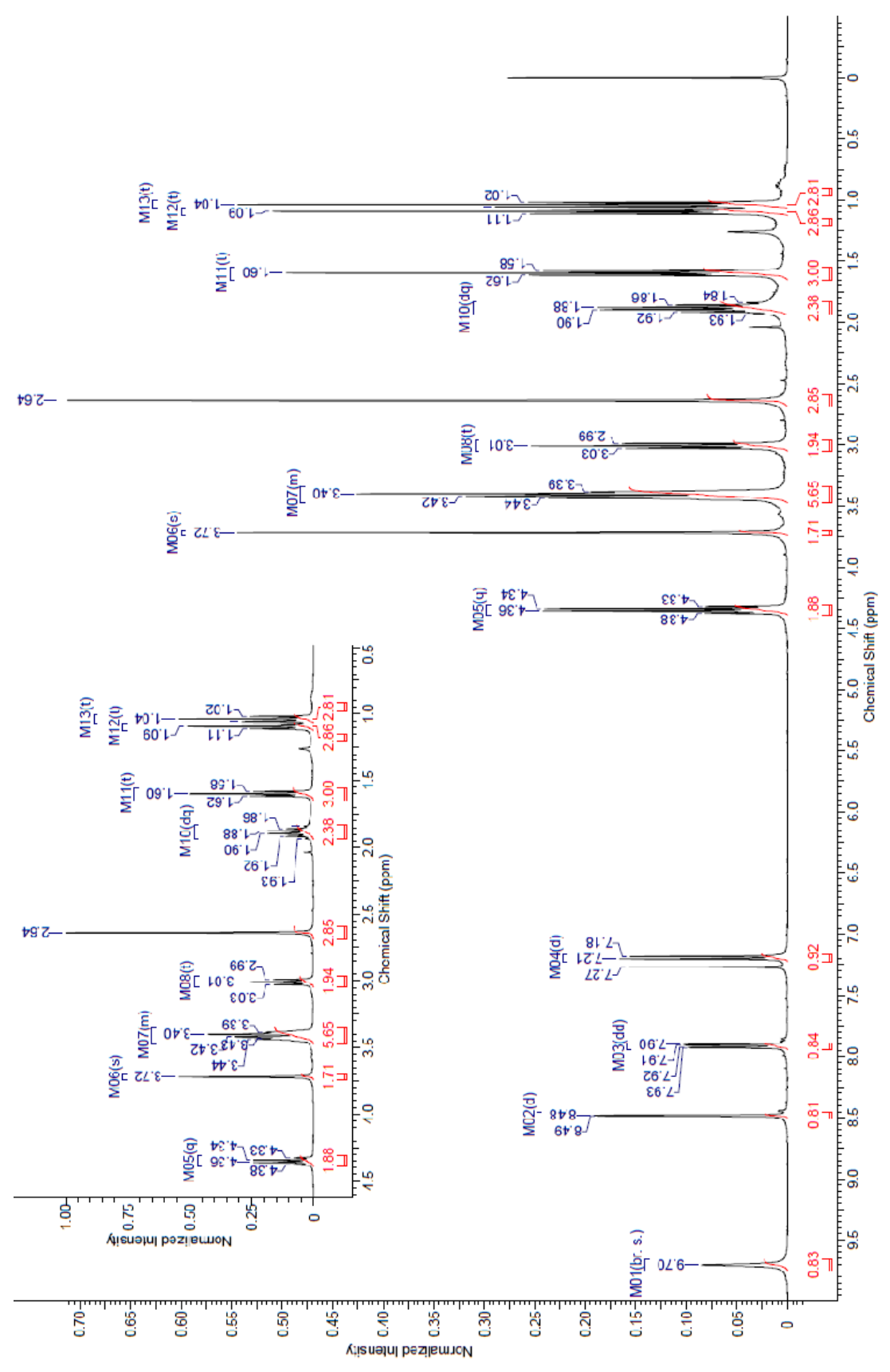


${ }^{13}$ C NMR

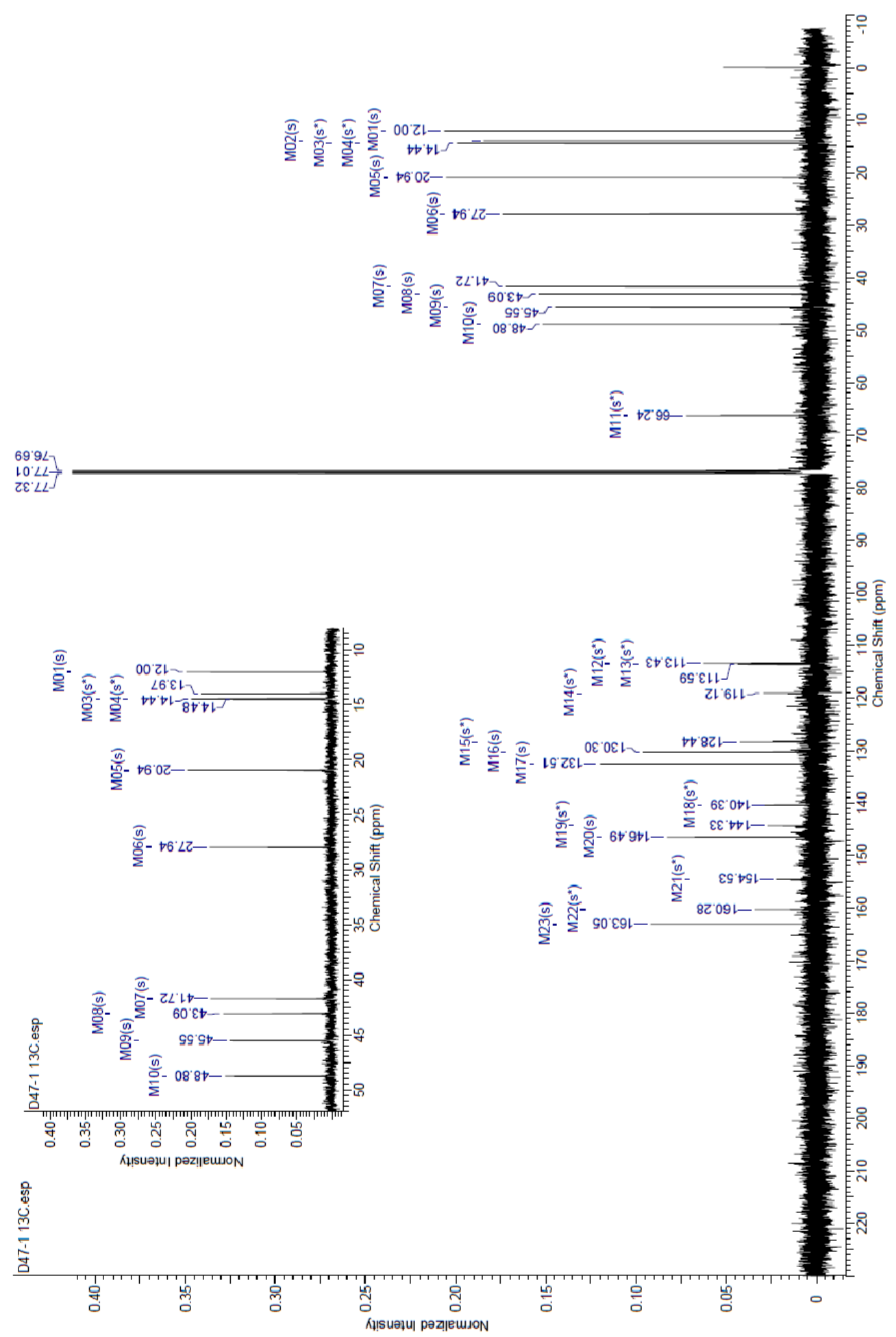




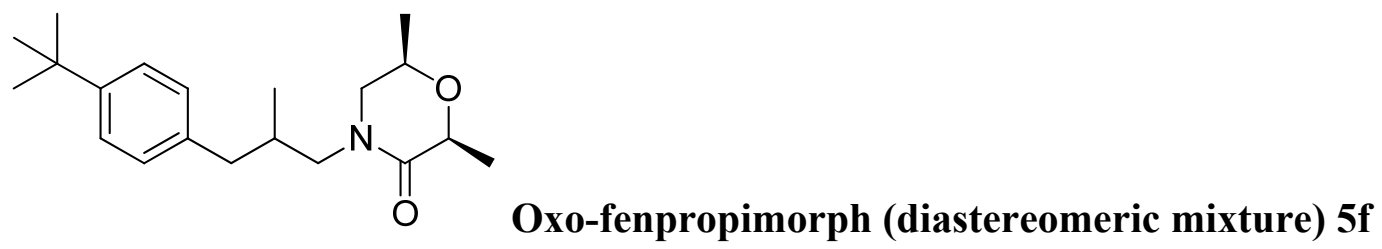

${ }^{1}$ H NMR

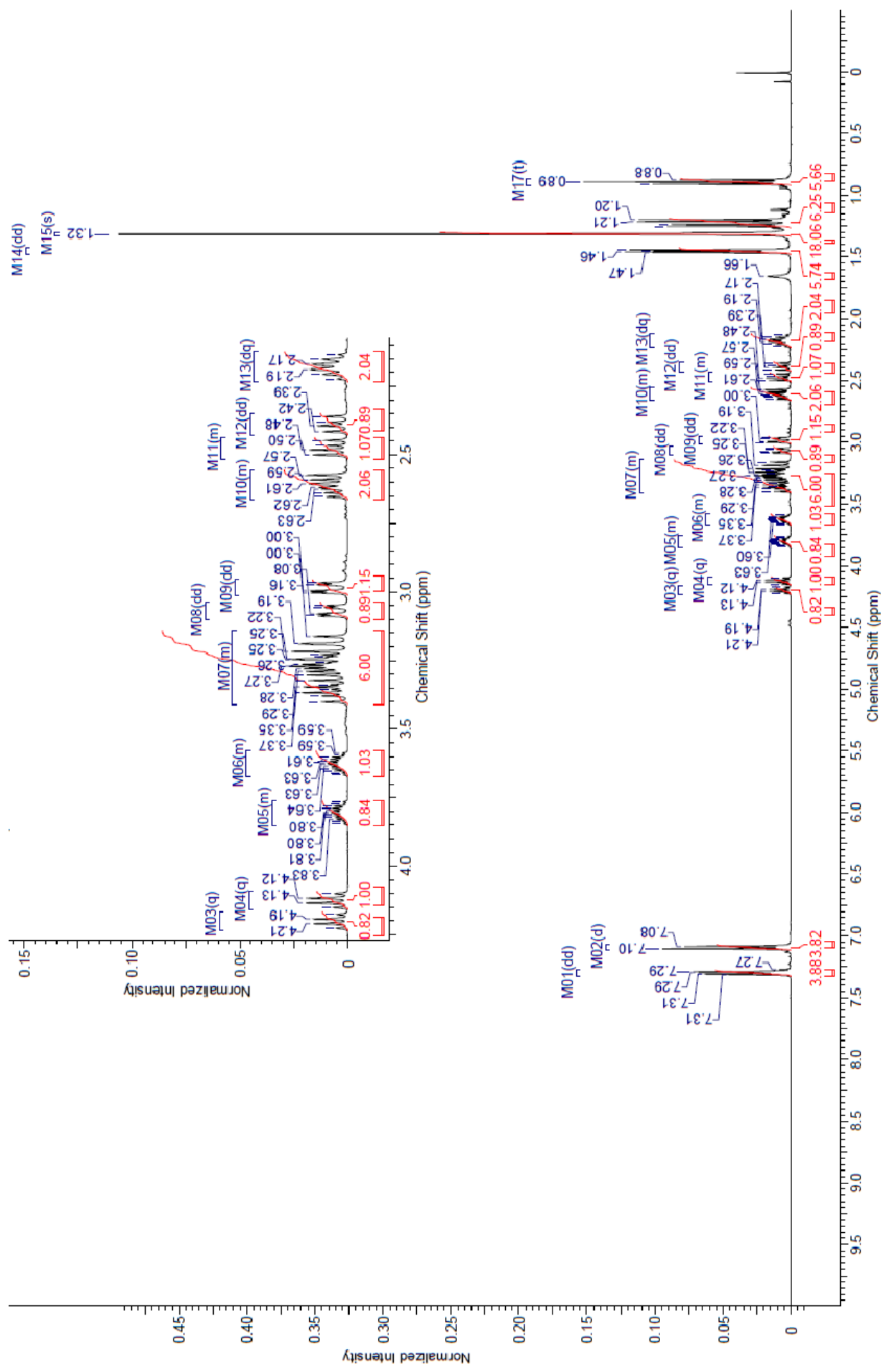




\section{${ }^{13} \mathrm{C}$ NMR}

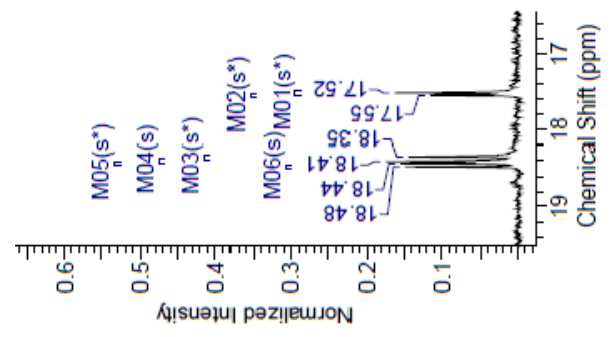

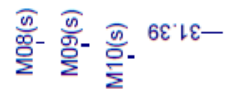

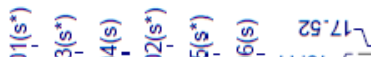
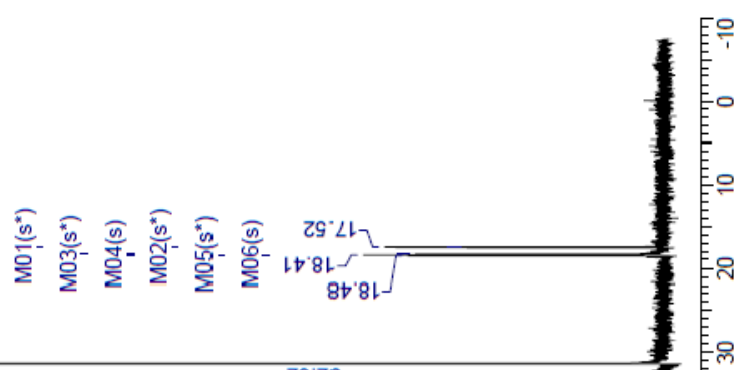

क्ञ⿰冫

क्ष $\quad \forall \varepsilon^{\prime} t \varepsilon$

$\sum \Sigma$

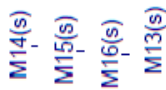

- $18 z 9$

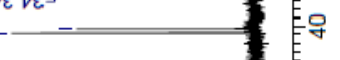

$8 L \varepsilon 9$

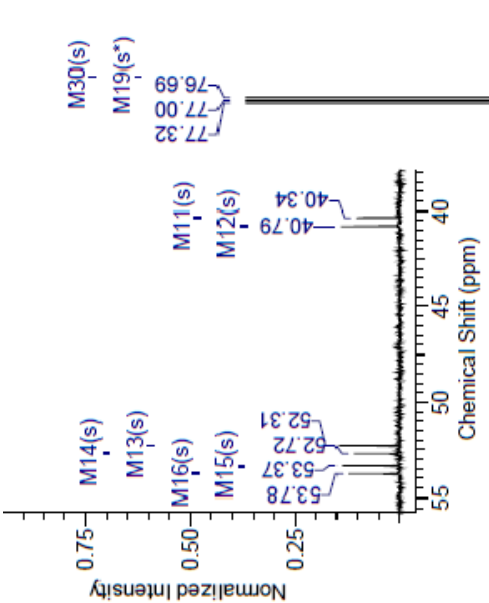

$\frac{\sqrt[m]{n}}{\frac{\pi}{2}} \frac{\widehat{m}}{\frac{\pi}{2}}$

商旁

$69.89-$

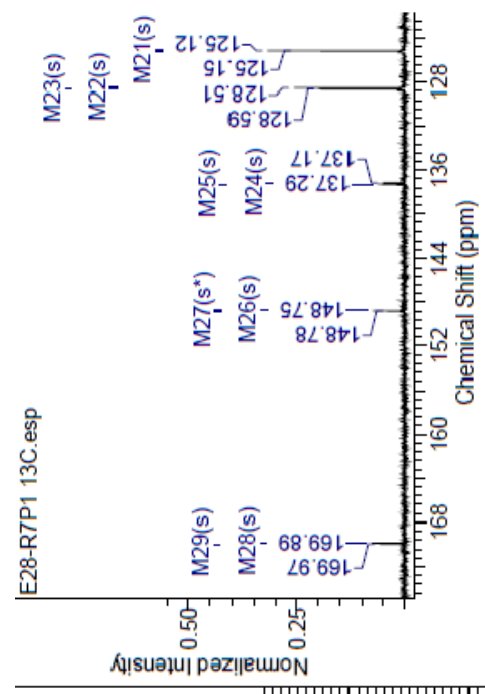

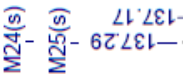

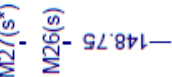

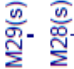

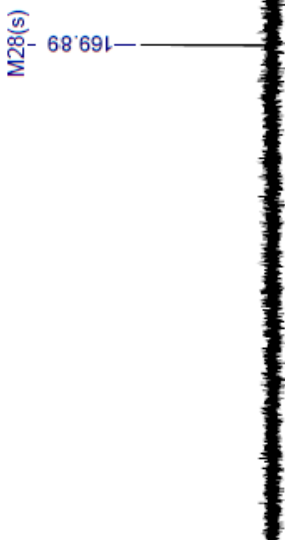

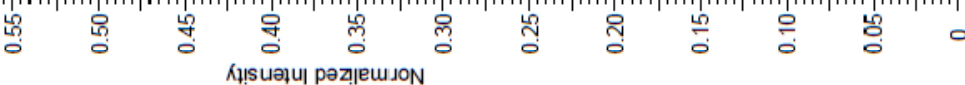


<smiles>CN1CCC(n2nc(Cc3ccc(Cl)cc3)c3ccccc3c2=O)CCC1=O</smiles>

7-Oxo-azelastine $5 \mathrm{~g}^{\alpha}$

\section{${ }^{1}$ H NMR}

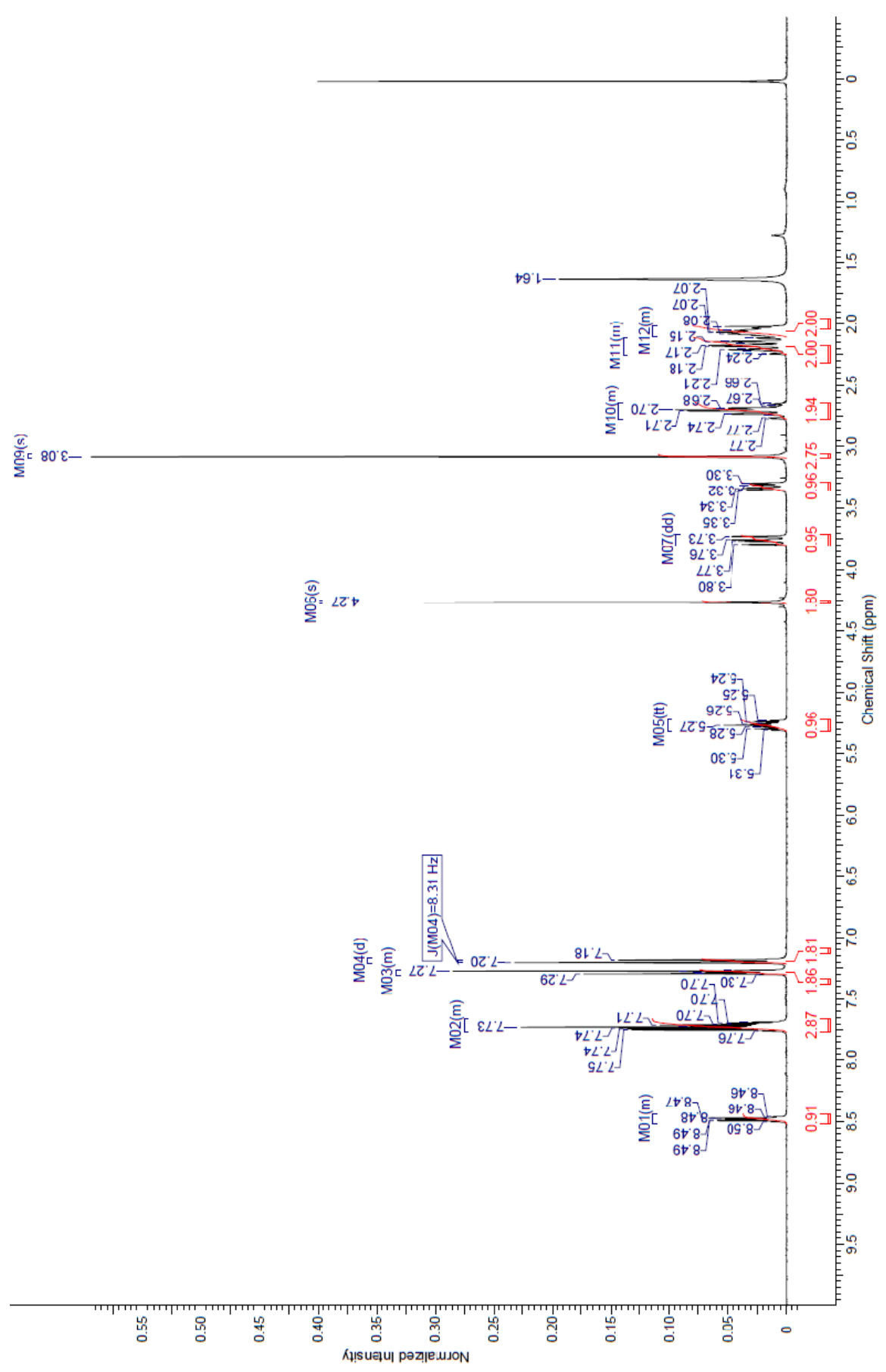




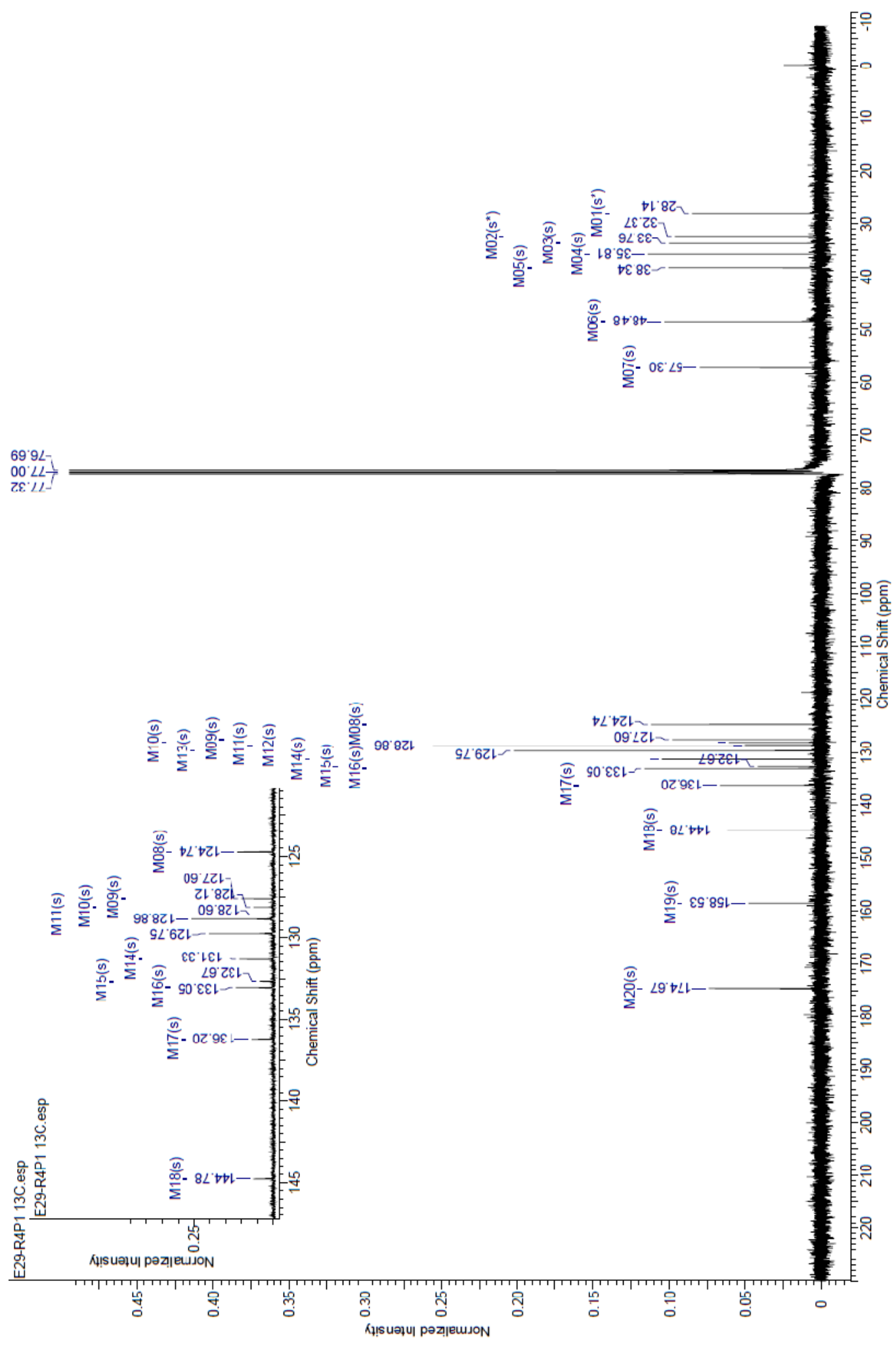




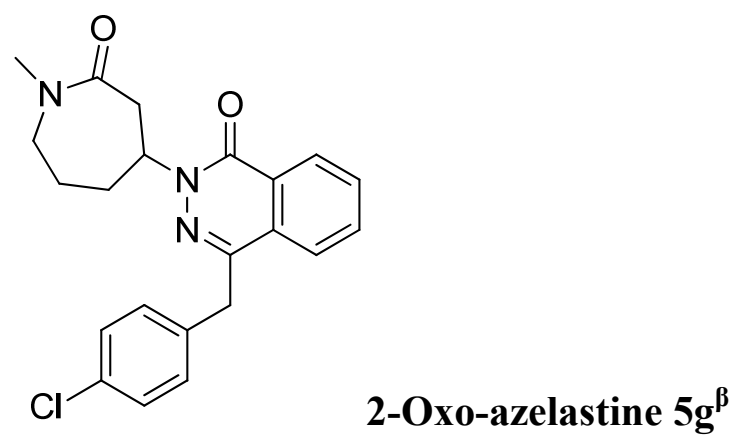

\section{${ }^{1}$ H NMR}

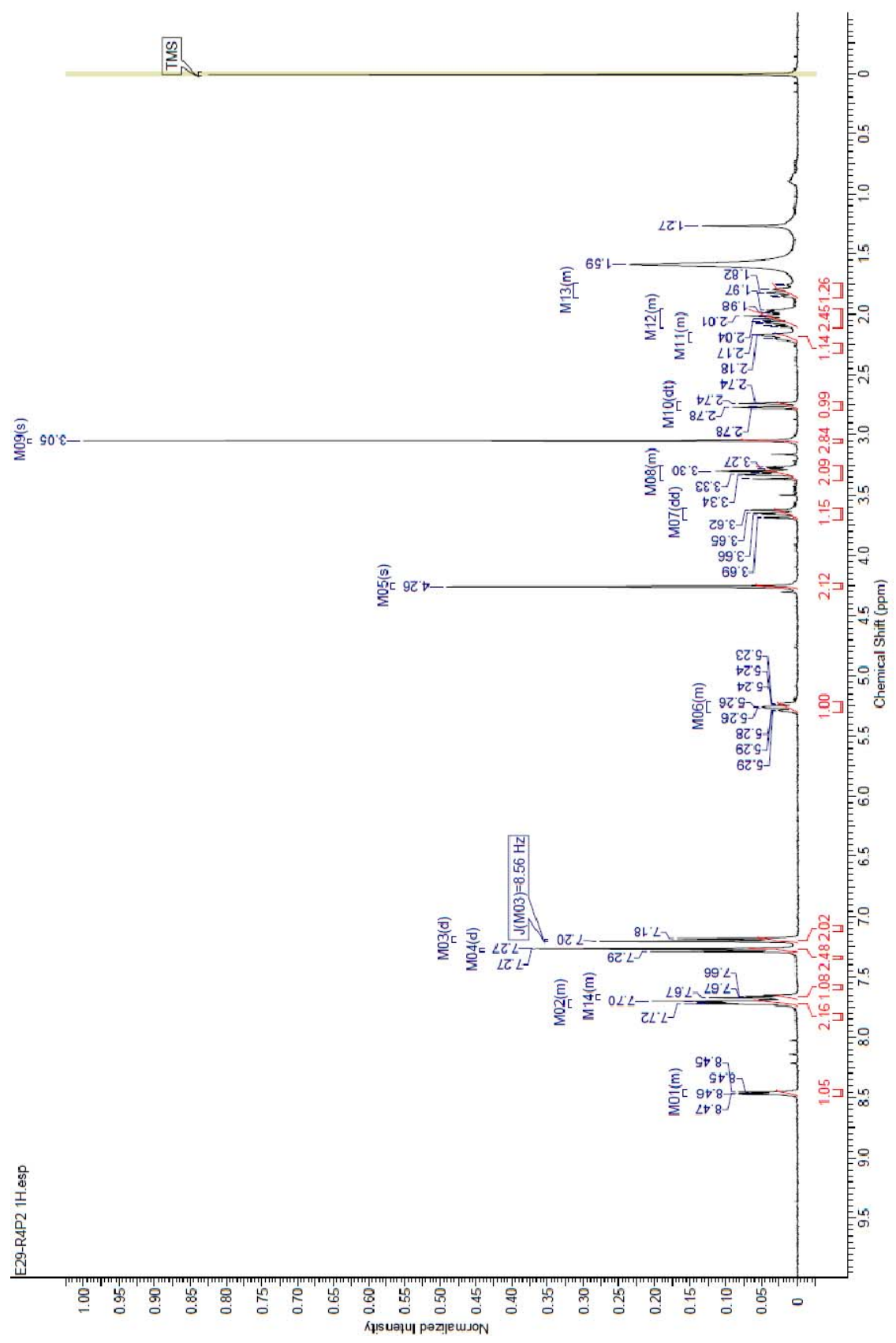




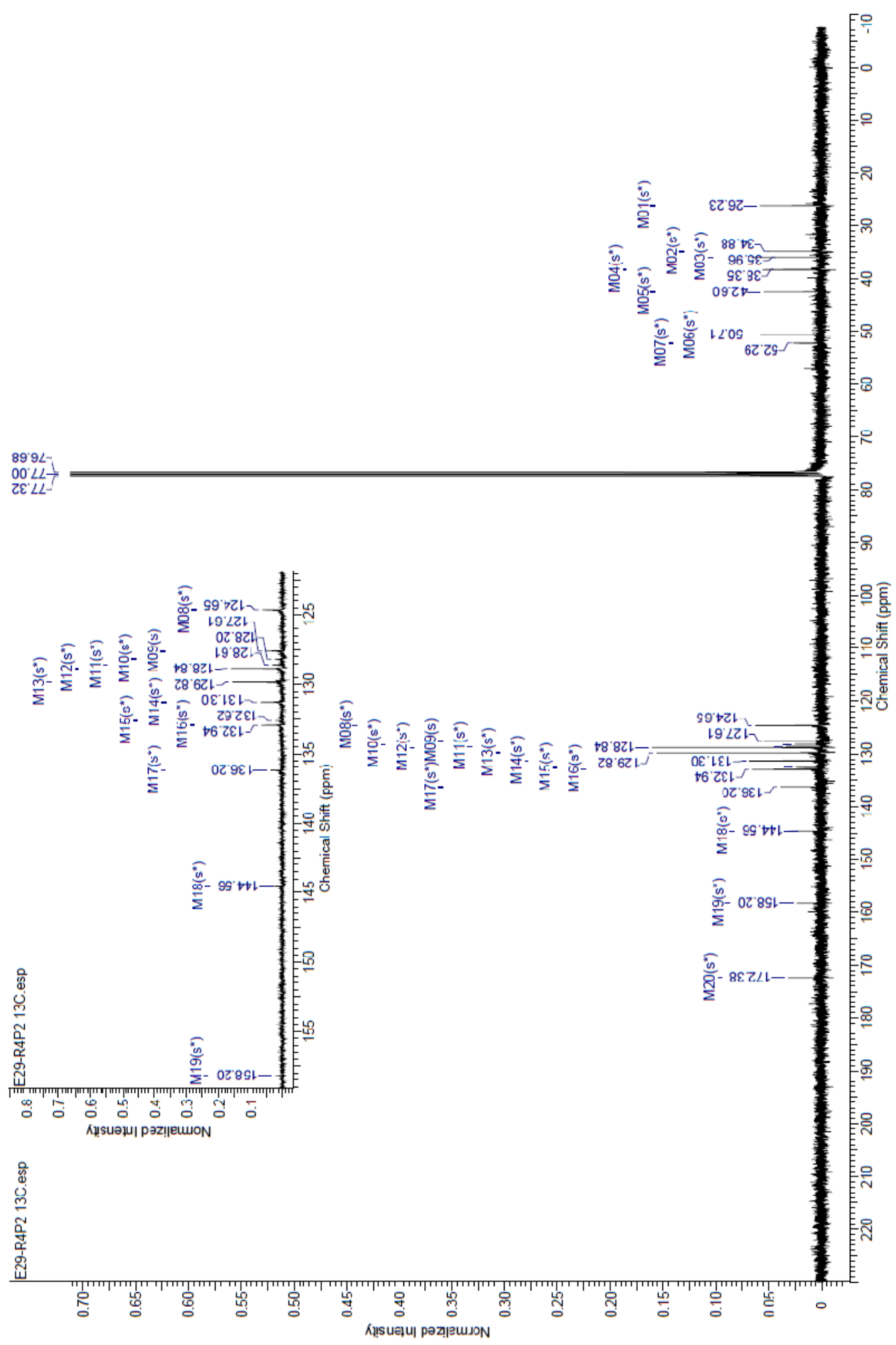


<smiles>CC1CCN(CCCC(=O)c2ccc(F)cc2)C(=O)C1</smiles>

Oxo-Melperone 5h

\section{${ }^{1}$ H NMR}

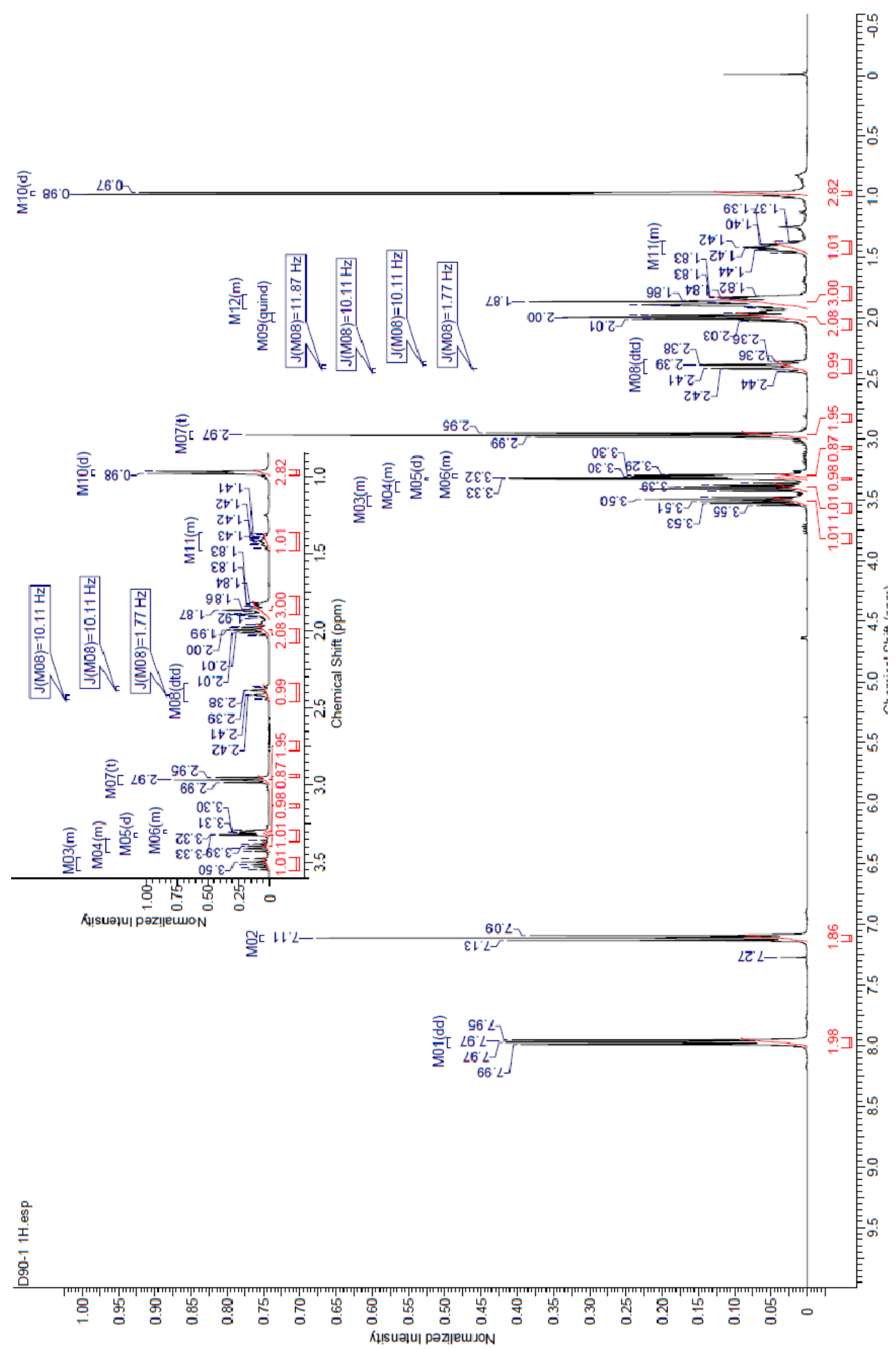




\section{${ }^{13}$ C NMR}

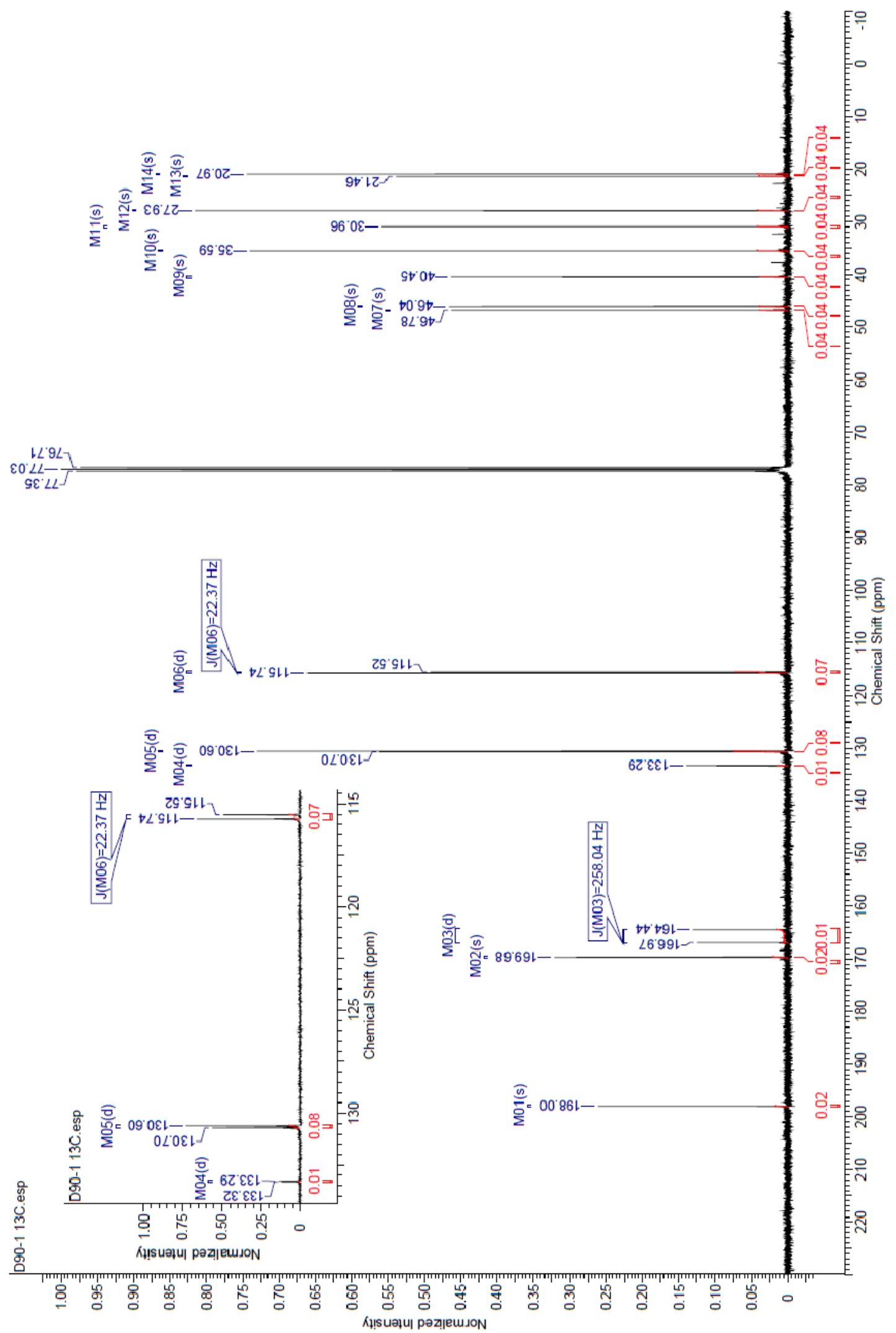


<smiles>CC(C)COCC(CN(Cc1ccccc1)c1ccccc1)N1CCCC1=O</smiles>

Oxo-Bepridil 5i

\section{${ }^{1}$ H NMR}

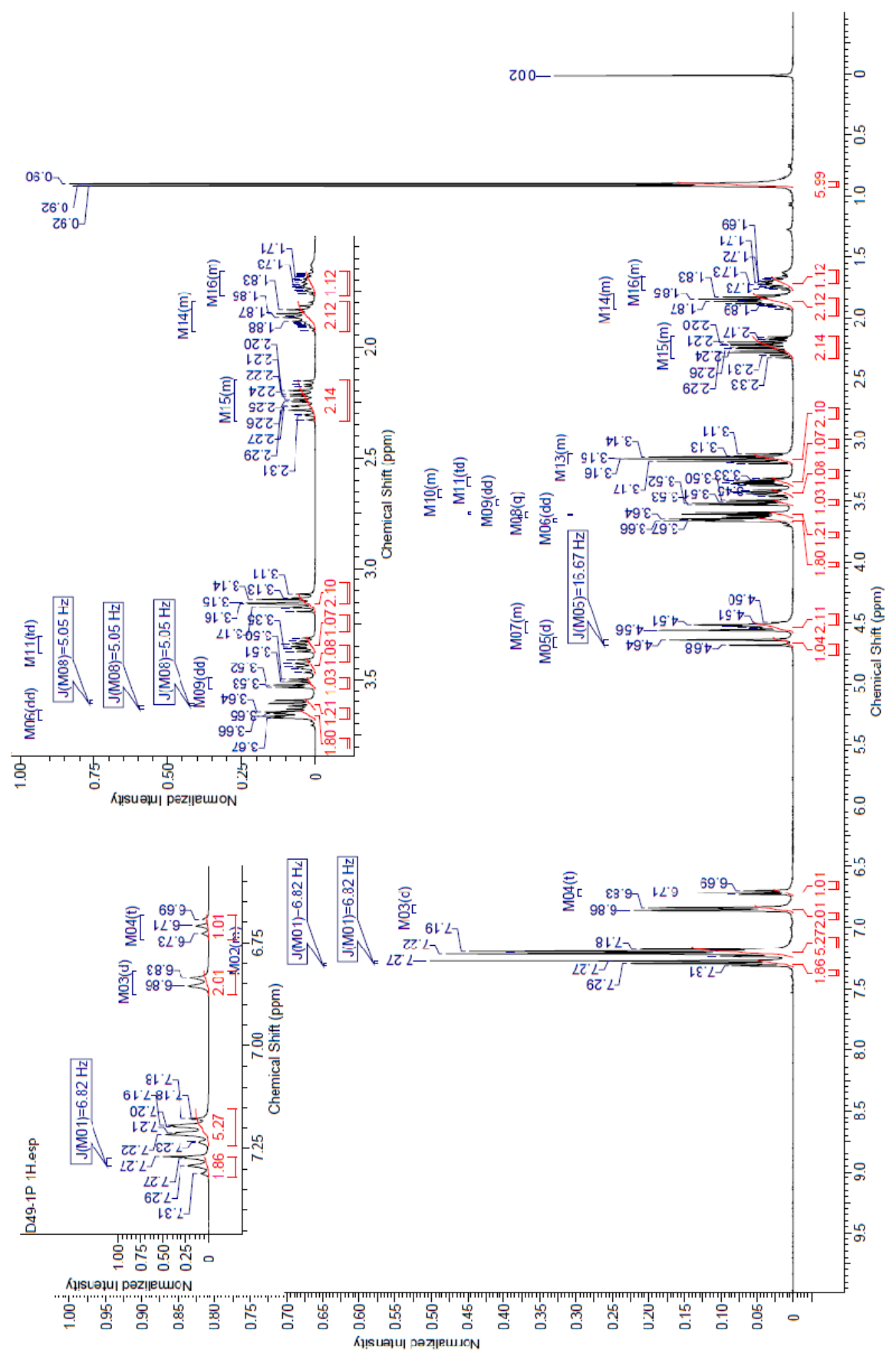


${ }^{13}$ C NMR

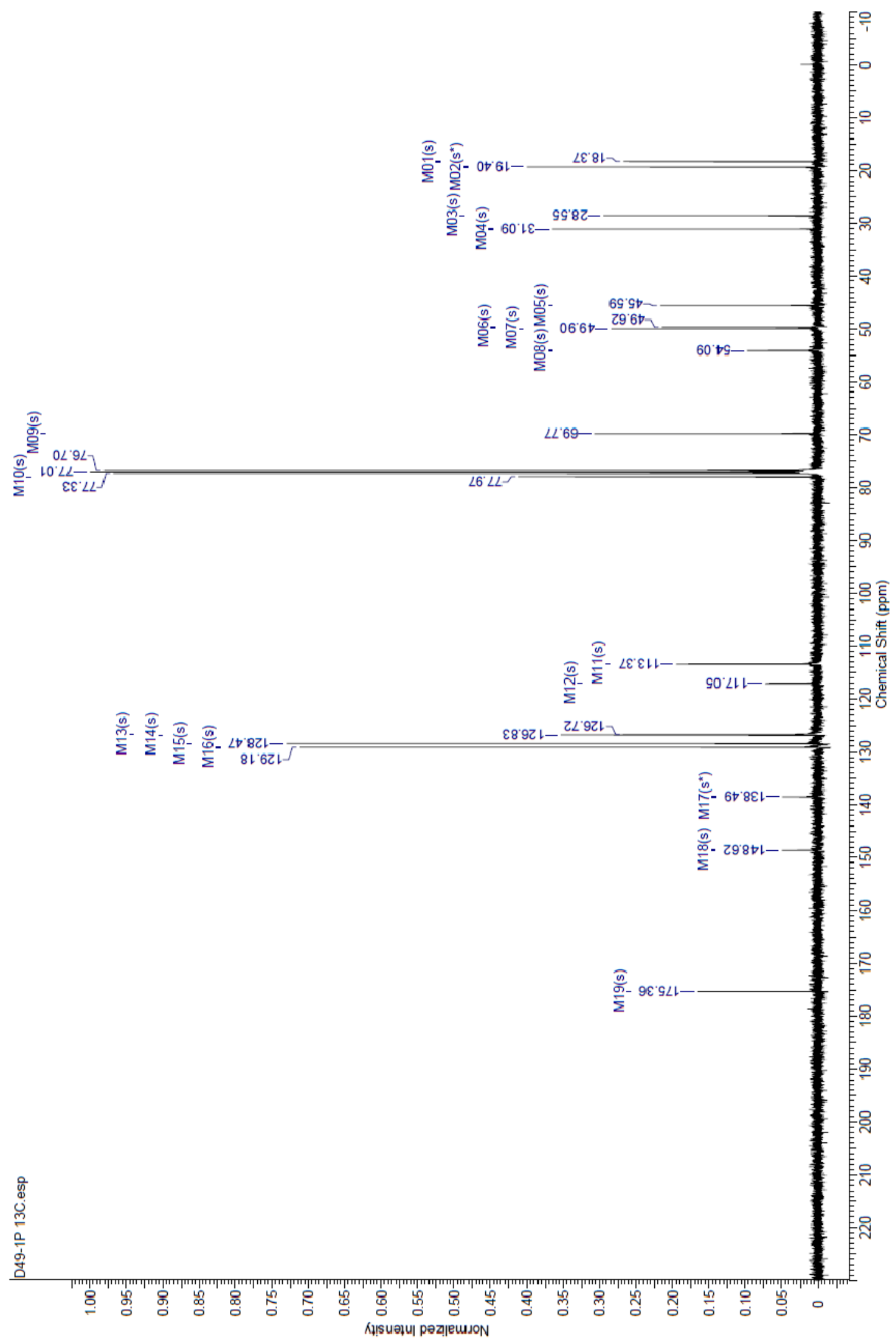




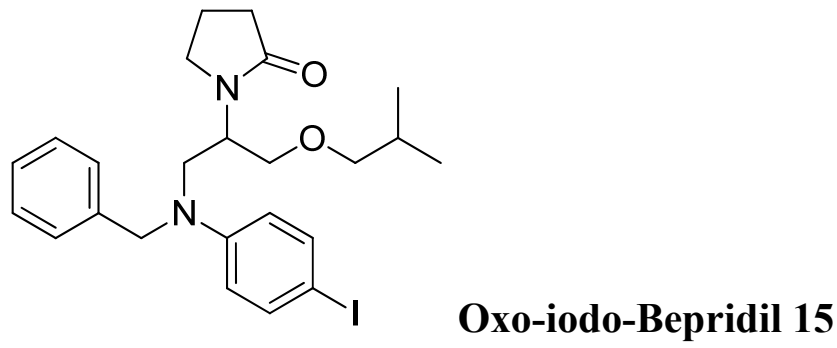

\section{${ }^{1}$ H NMR}

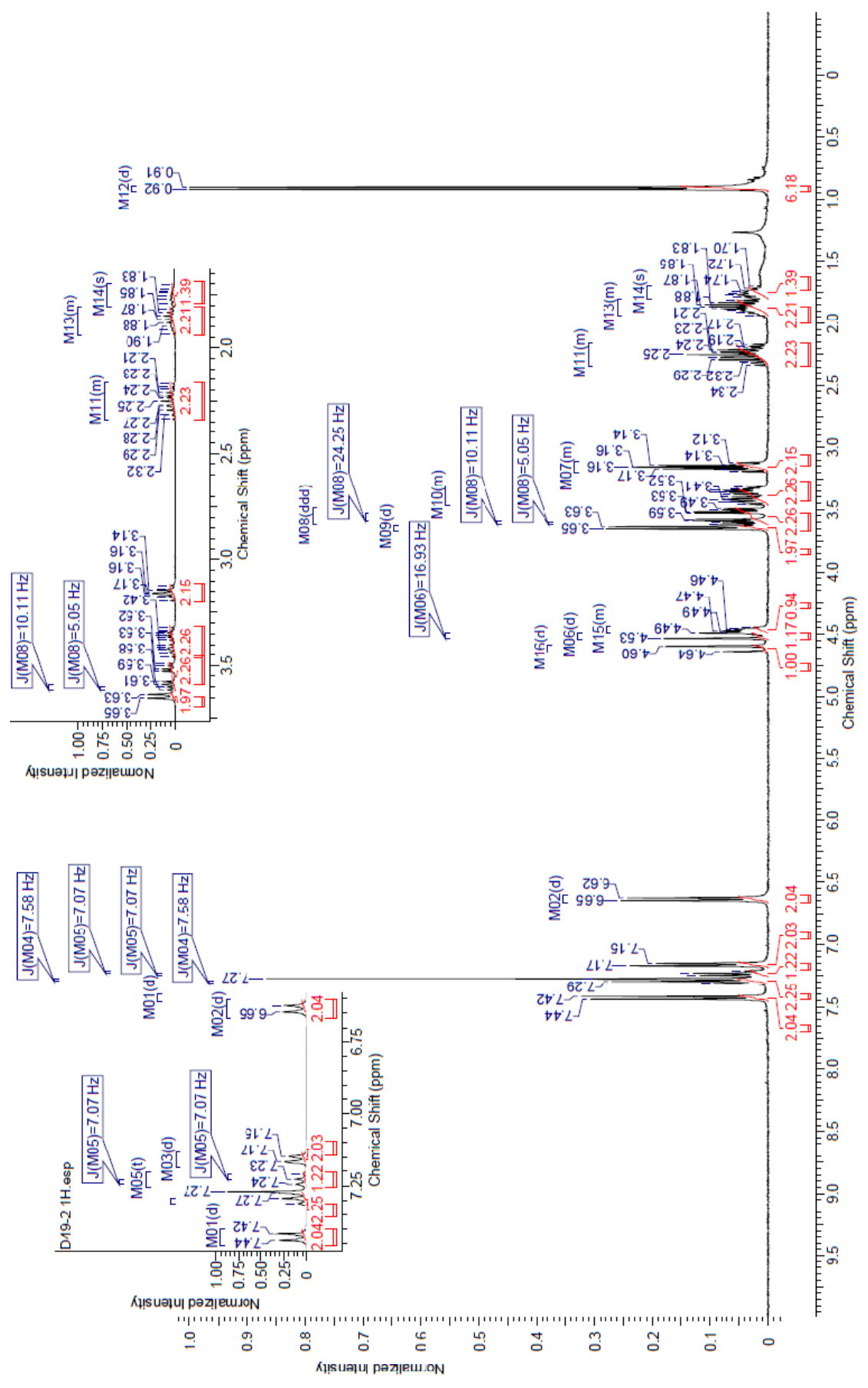




\section{${ }^{13}$ C NMR}

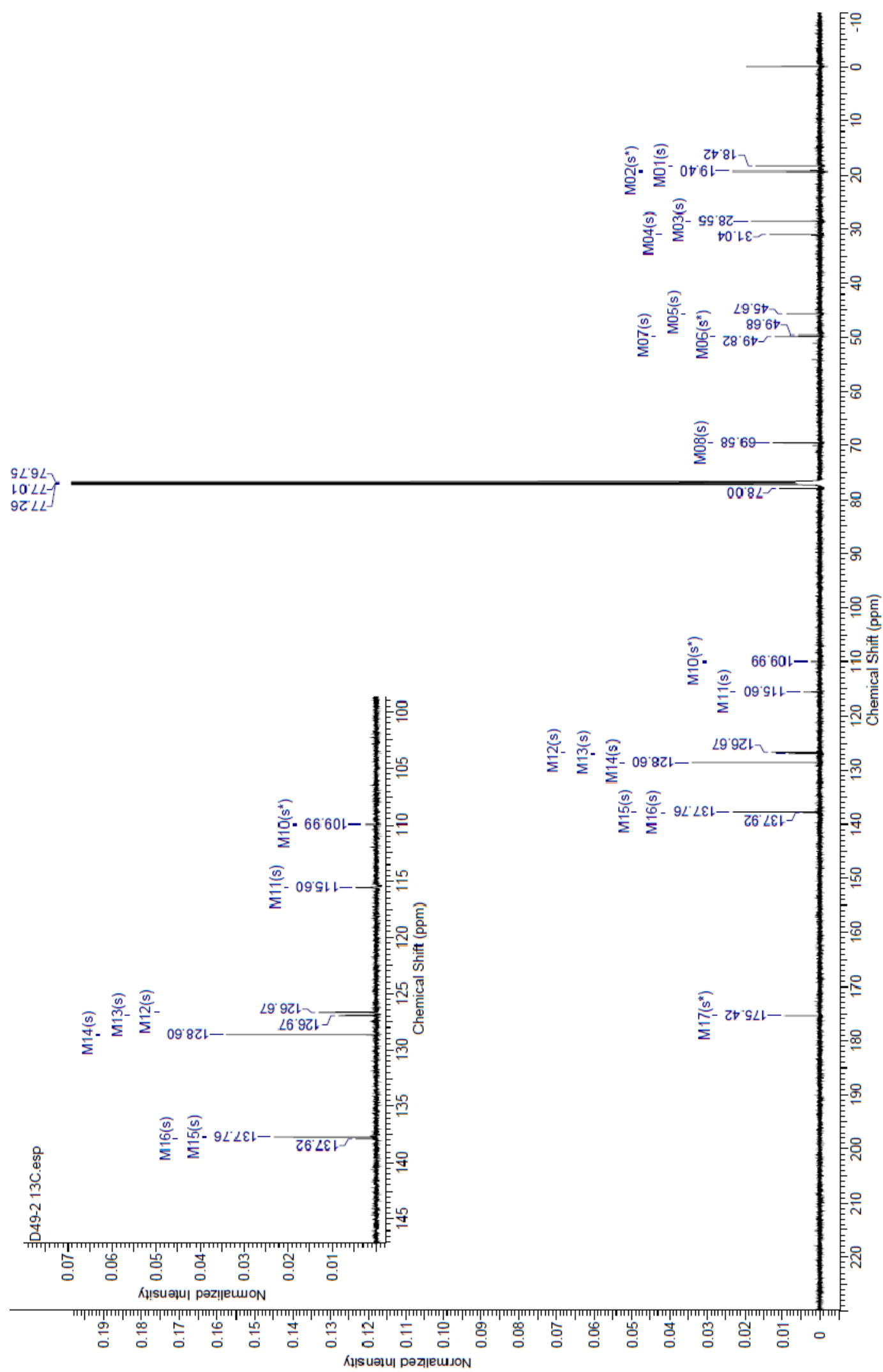


<smiles>CNS(=O)(=O)CCc1ccc2c(c1)C1(CCC1)C1CC[N+](C)(C2)C1=O</smiles>

[bicyclo[2.2.1] heptane-7,3'-indolin]-1-ium iodide 14

1-Methyl-5'-(2-( $N$-methylsulfamoyl)ethyl)-2'-oxo-1-azaspiro

\section{${ }^{1}$ H NMR}

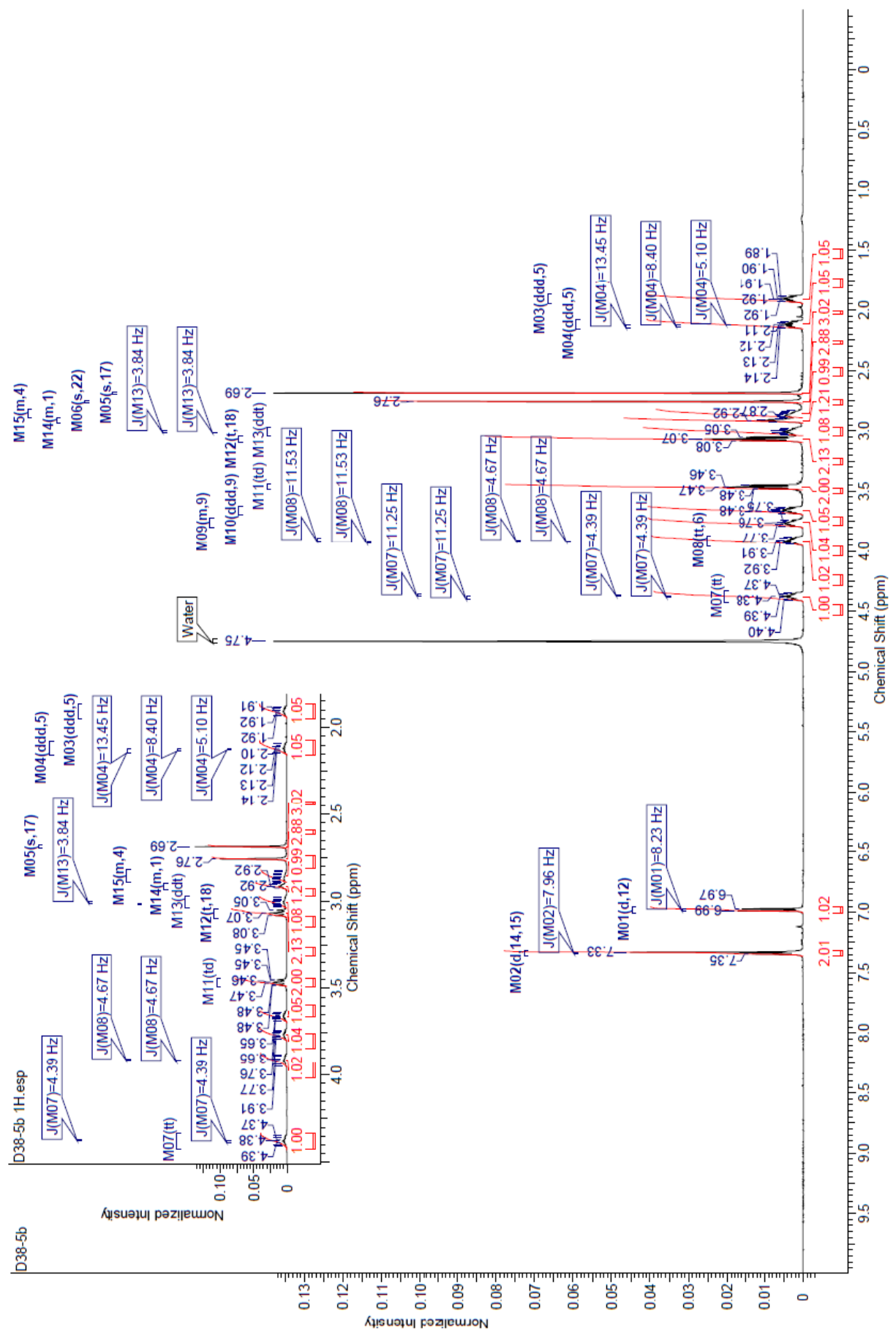


${ }^{13}$ C NMR

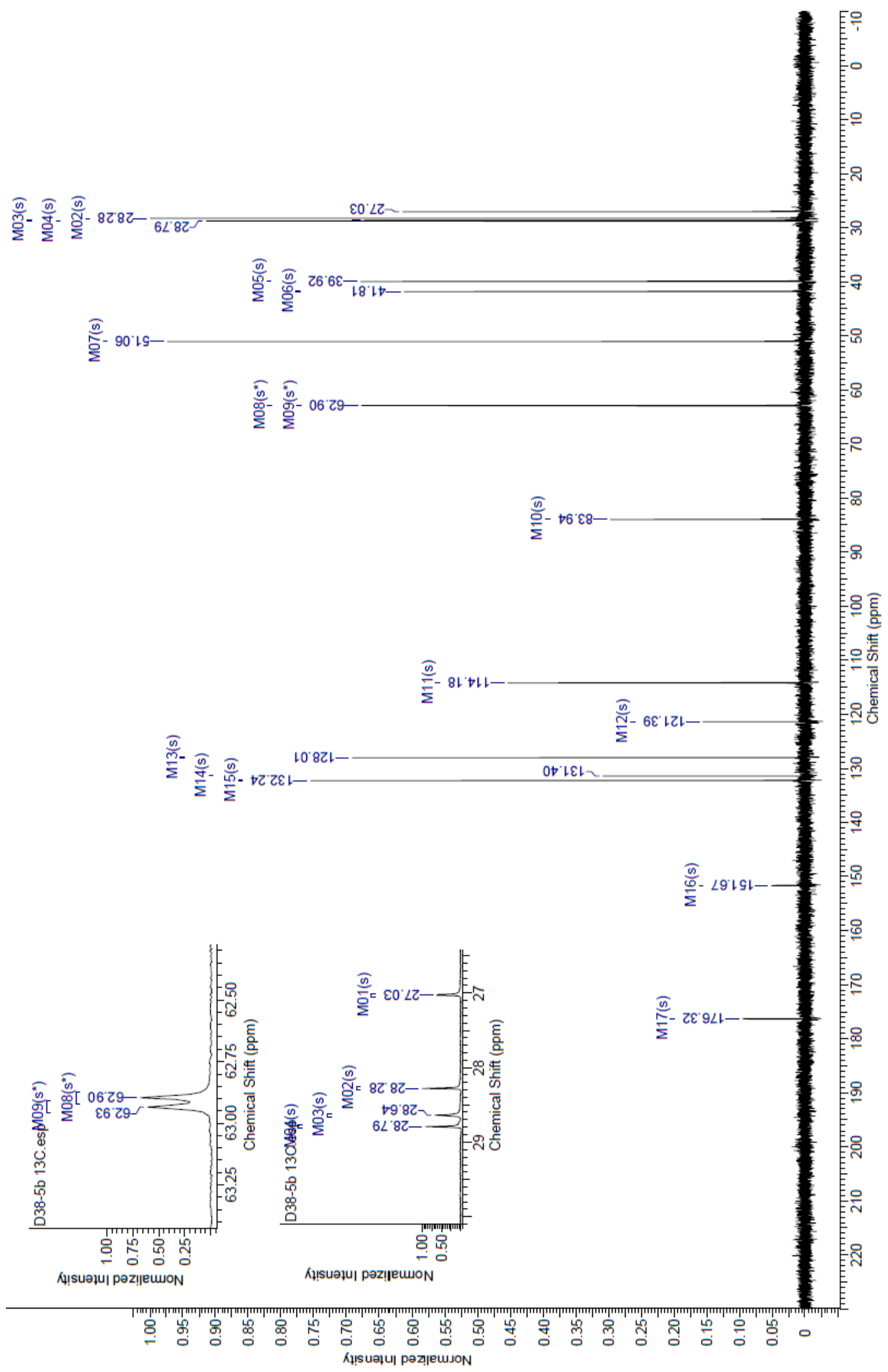




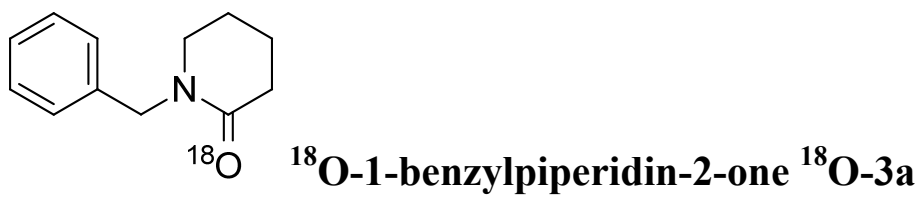

\section{${ }^{1}$ H NMR}

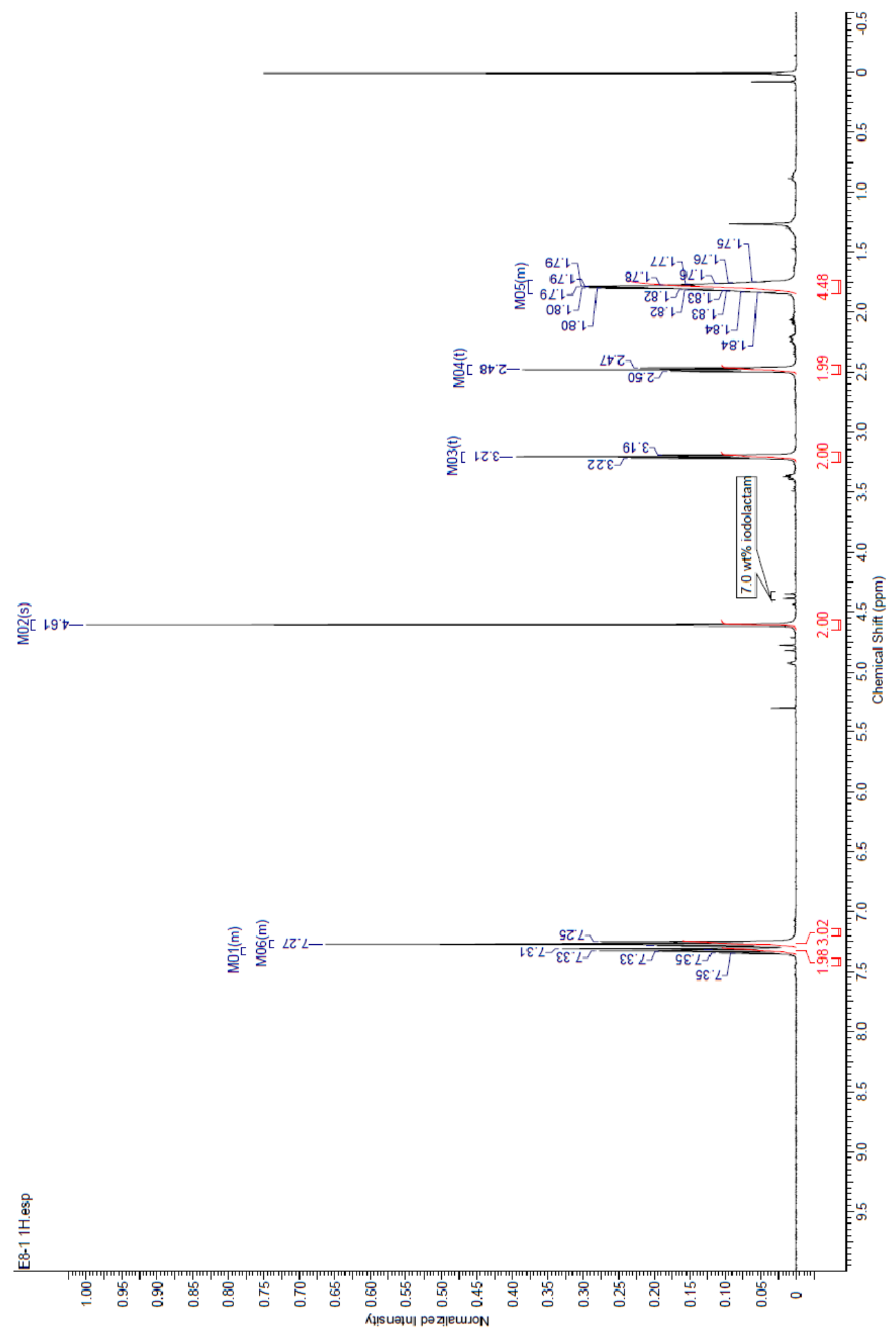


$\mathrm{NaHCO}_{3} / \mathrm{H}_{2}{ }^{18} \mathrm{O}$ reaction LCMS

(Time: 0.86$)$

1 : MS ES+

$5.5 e+007$

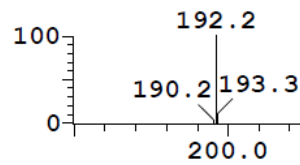

383.3

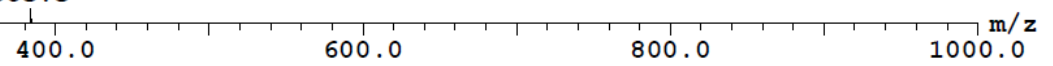

\section{$\mathrm{NaOAc} / \mathrm{H}_{2} \mathrm{O}$ reaction LCMS}

(Time: 0.86$)$

$1:$ MS ES+

100

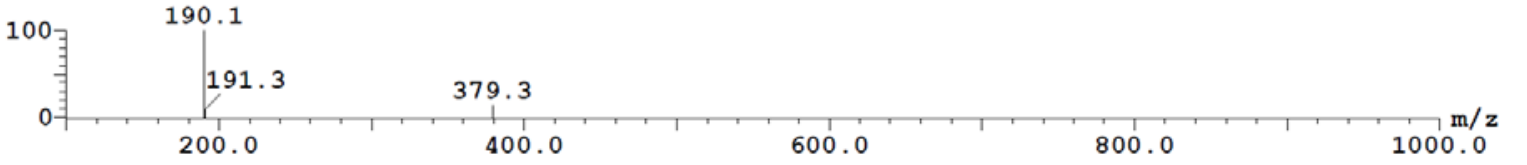

$\mathrm{Na}^{18} \mathrm{OAc} / \mathrm{H}_{2} \mathrm{O}$ reaction LCMS

(Time: 0.85 )

1: MS ES+

5. $2 \mathrm{e}+007$

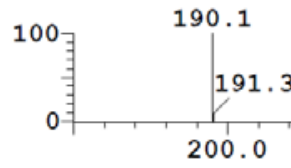

379.3

400.0

600.0

800.0

1000.0

$\mathrm{Na}^{18} \mathrm{OAc} / \mathrm{H}_{2}{ }^{18} \mathrm{O}$ reaction LCMS

(Time: 0.86 )

1 : MS ES+

5. $2 \mathrm{e}+007$

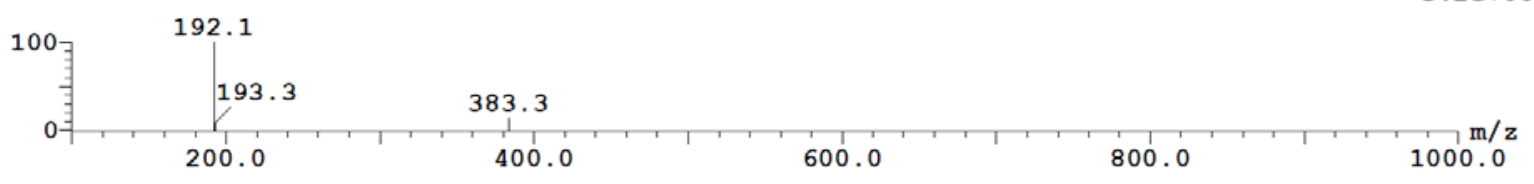


Investigating late-stage oxidation under Milstein conditions

Applied to substrate $4 \mathrm{~h}$

${ }^{1}$ H NMR of crude product

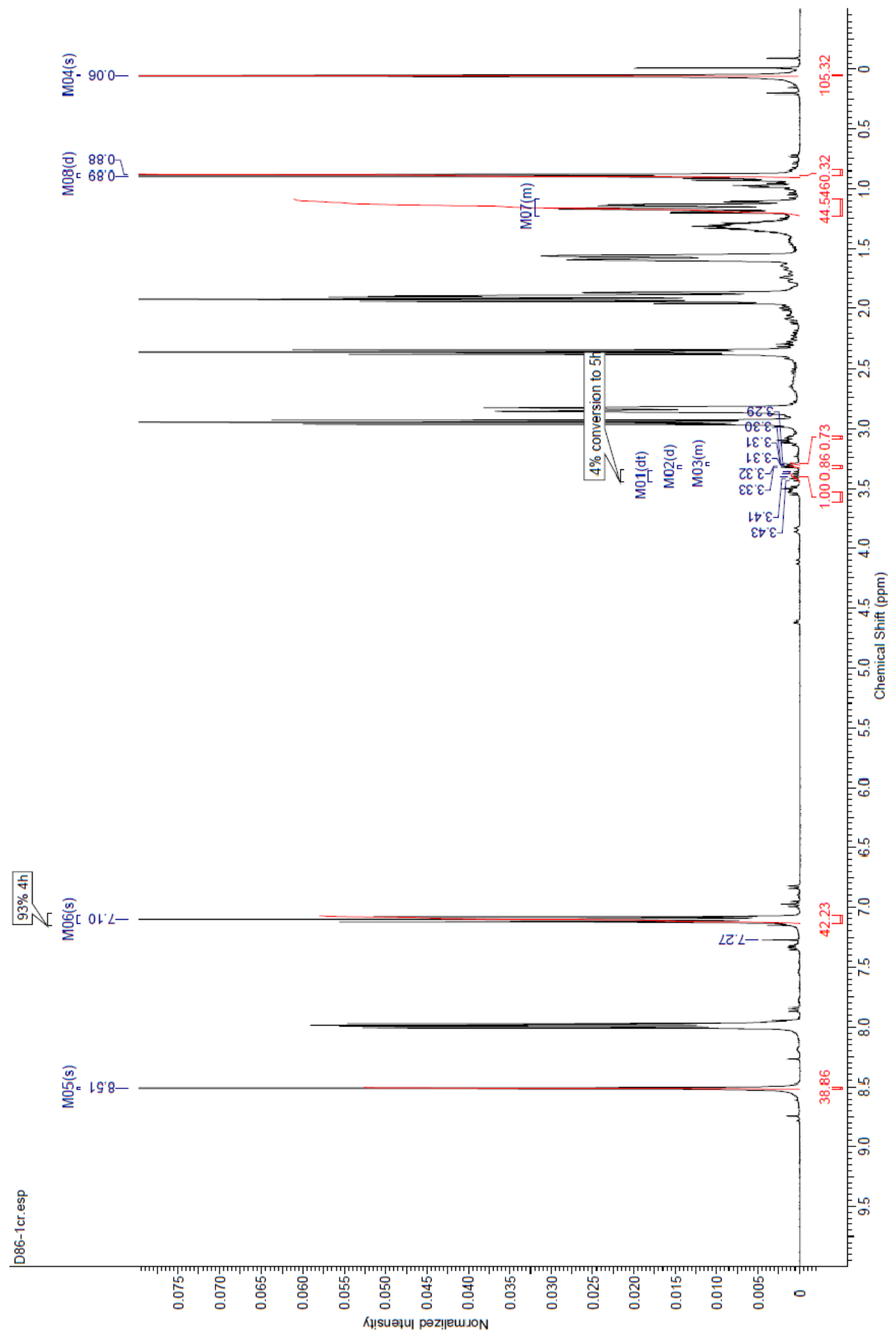


High pH LCMS spectrum of reaction mixture

$\left(\right.$ Starting material $R_{t}=1.23$ min)

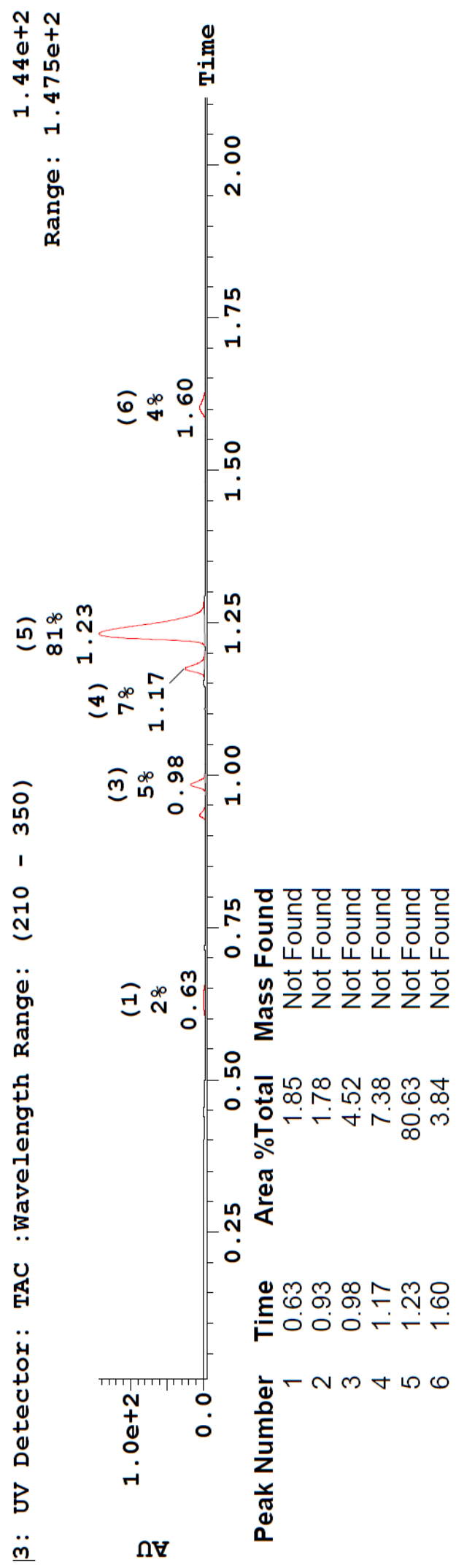


Applied to substrate 4i

${ }^{1}$ H NMR of crude product

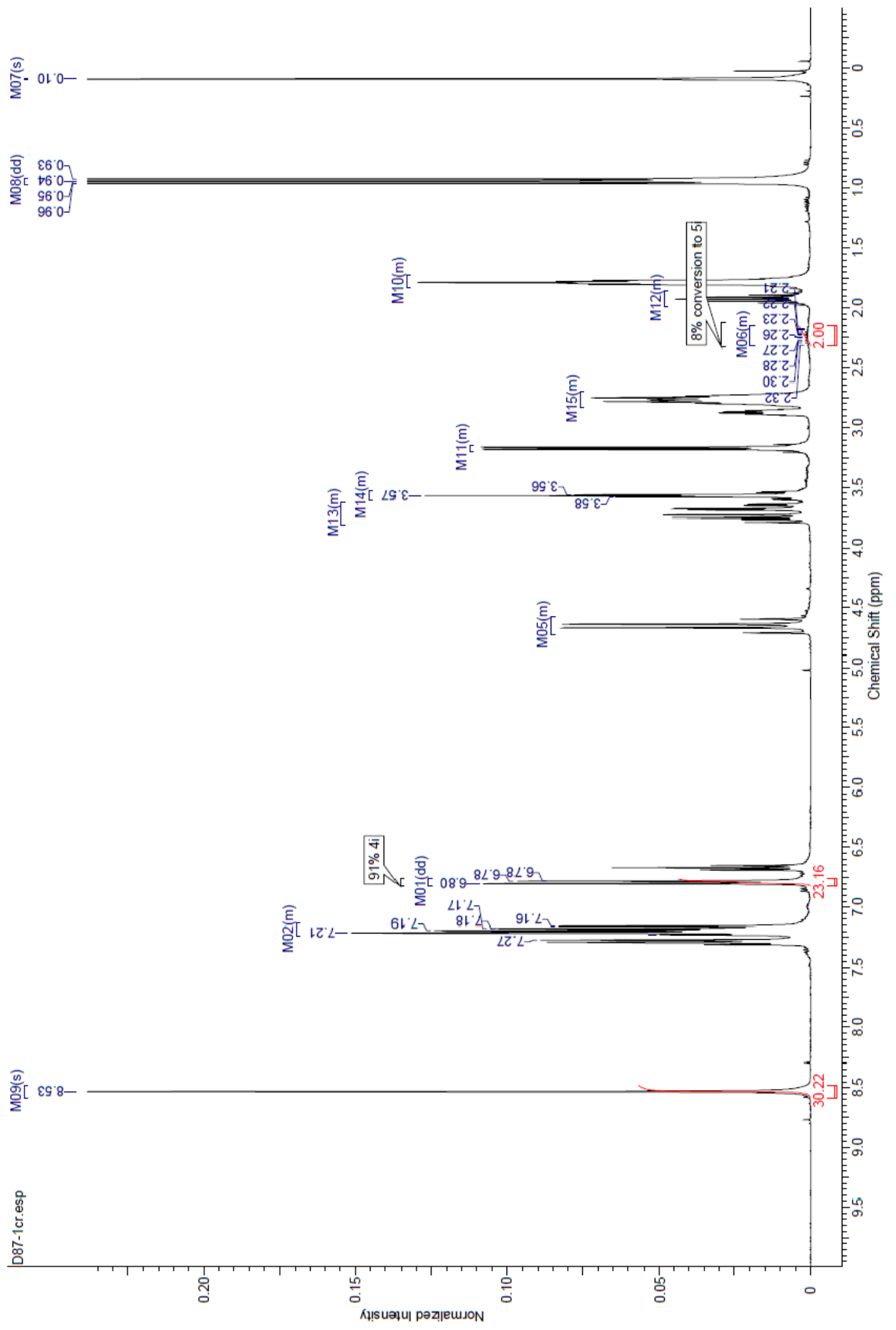


High pH LCMS spectrum of reaction mixture

$\left(\right.$ Starting material $\left.R_{t}=\mathbf{1 . 6 7} \mathbf{~ m i n}\right)$

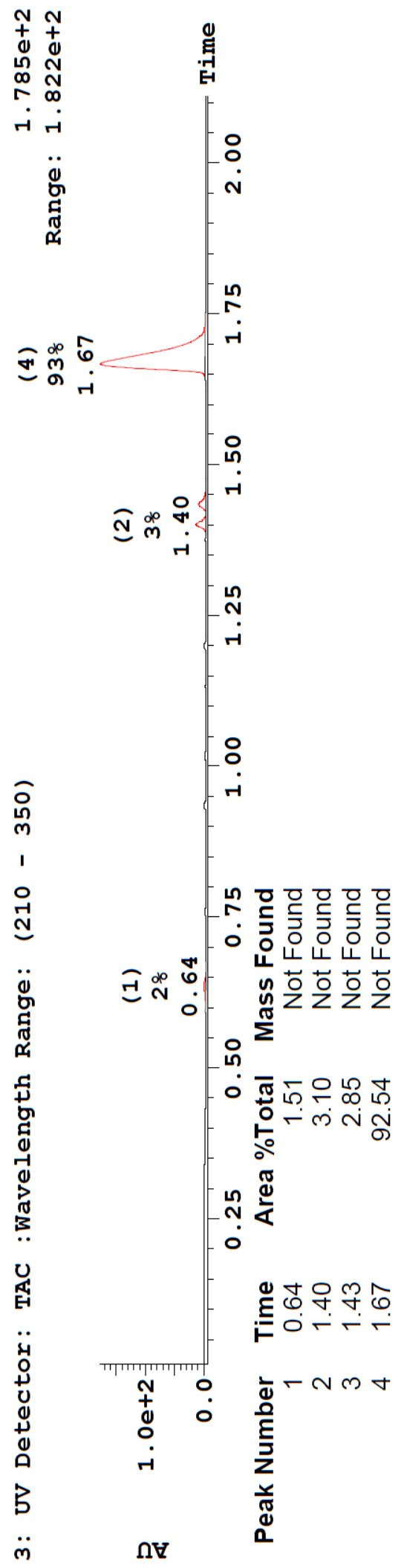


Investigating late-stage oxidation under Emmert conditions

Applied to substrate $4 \mathrm{~h}$

${ }^{1}$ H NMR of crude product

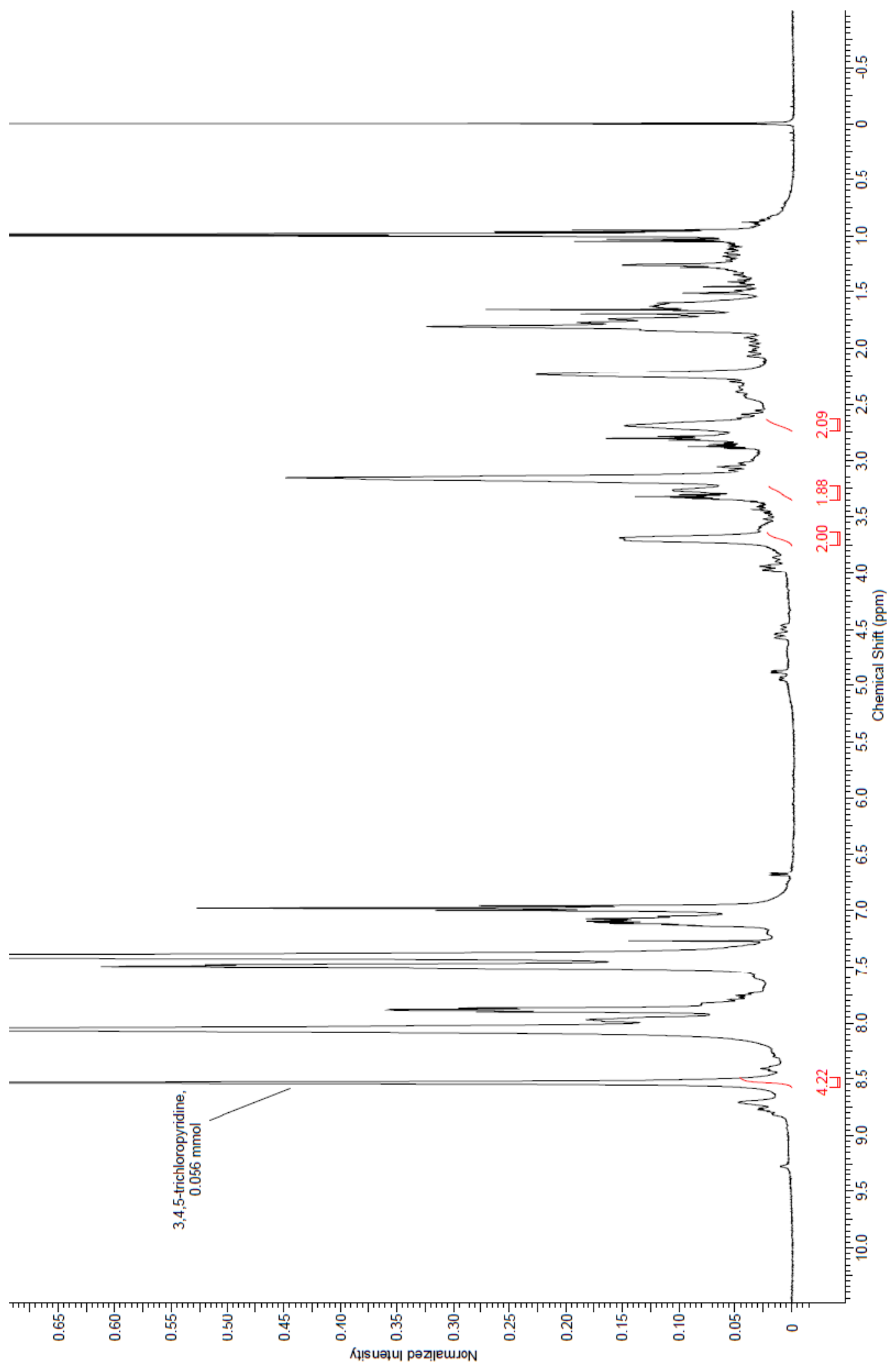


High pH LCMS spectrum of reaction mixture

$\left(\right.$ Starting material $\left.R_{t}=1.22 \mathrm{~min}\right)$

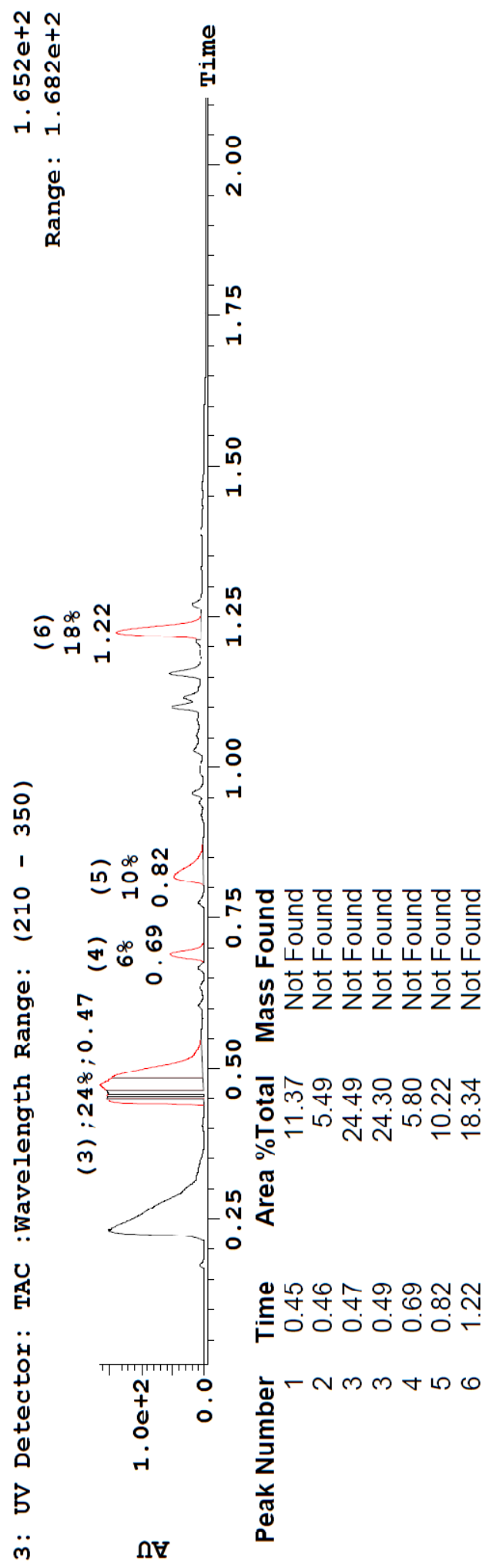


Applied to substrate 4i

${ }^{1}$ H NMR of crude product

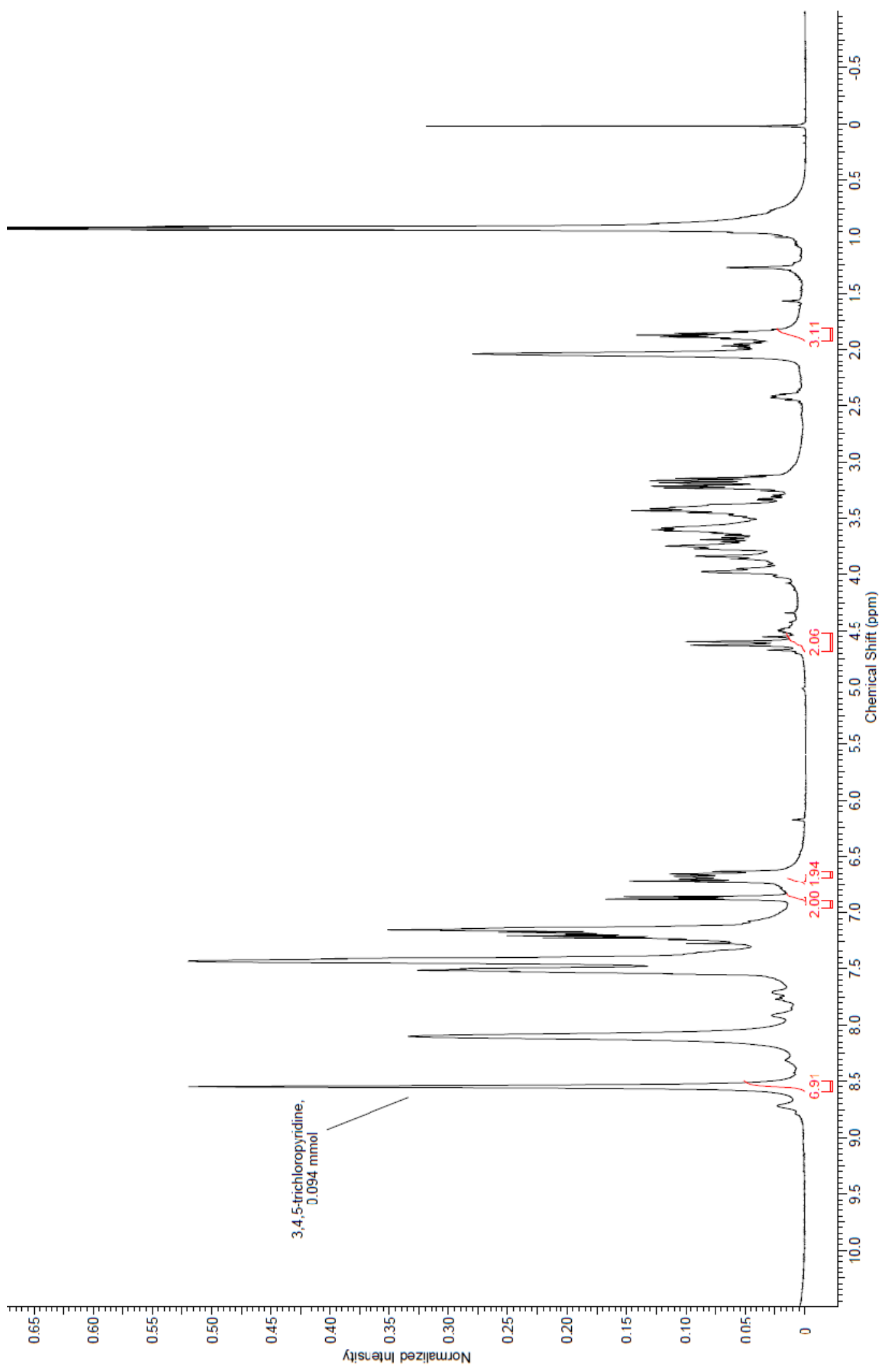


High pH LCMS spectrum of reaction mixture

$\left(\right.$ Starting material $\left.R_{t}=\mathbf{1 . 6 8} \mathbf{m i n}\right)$

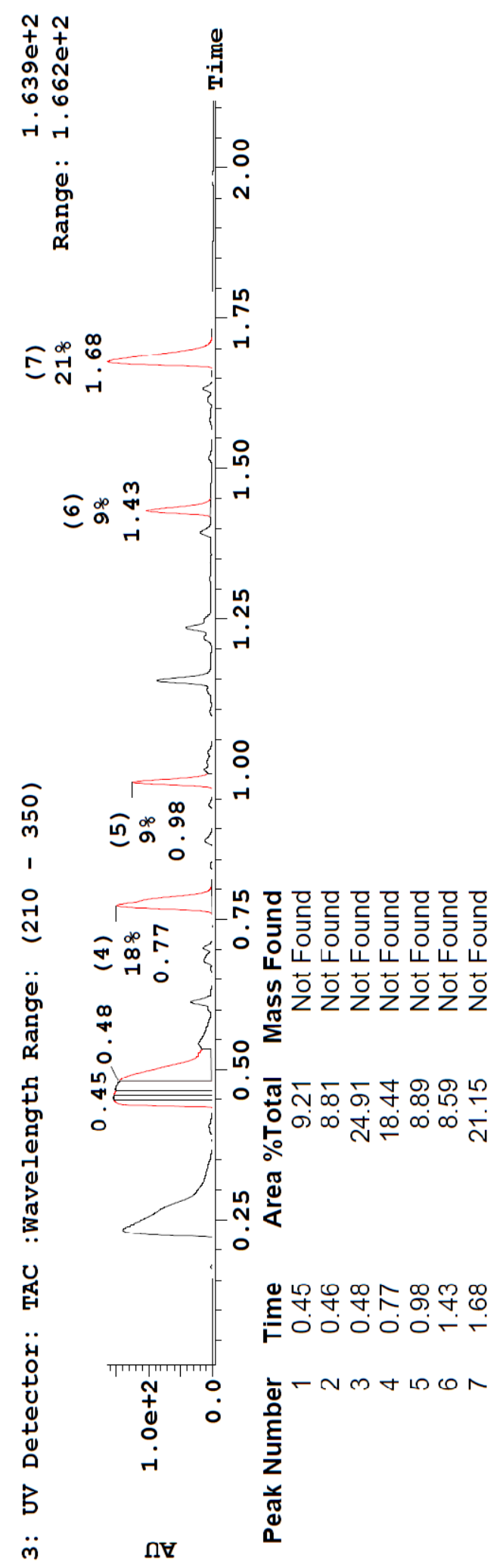


Investigating late-stage oxidation under classical $\mathrm{Ru}^{\mathrm{IV}} \mathrm{O}_{2} / \mathrm{NaIO}_{4}$ conditions

Applied to substrate $4 \mathrm{~h}$

${ }^{1}$ H NMR of crude product

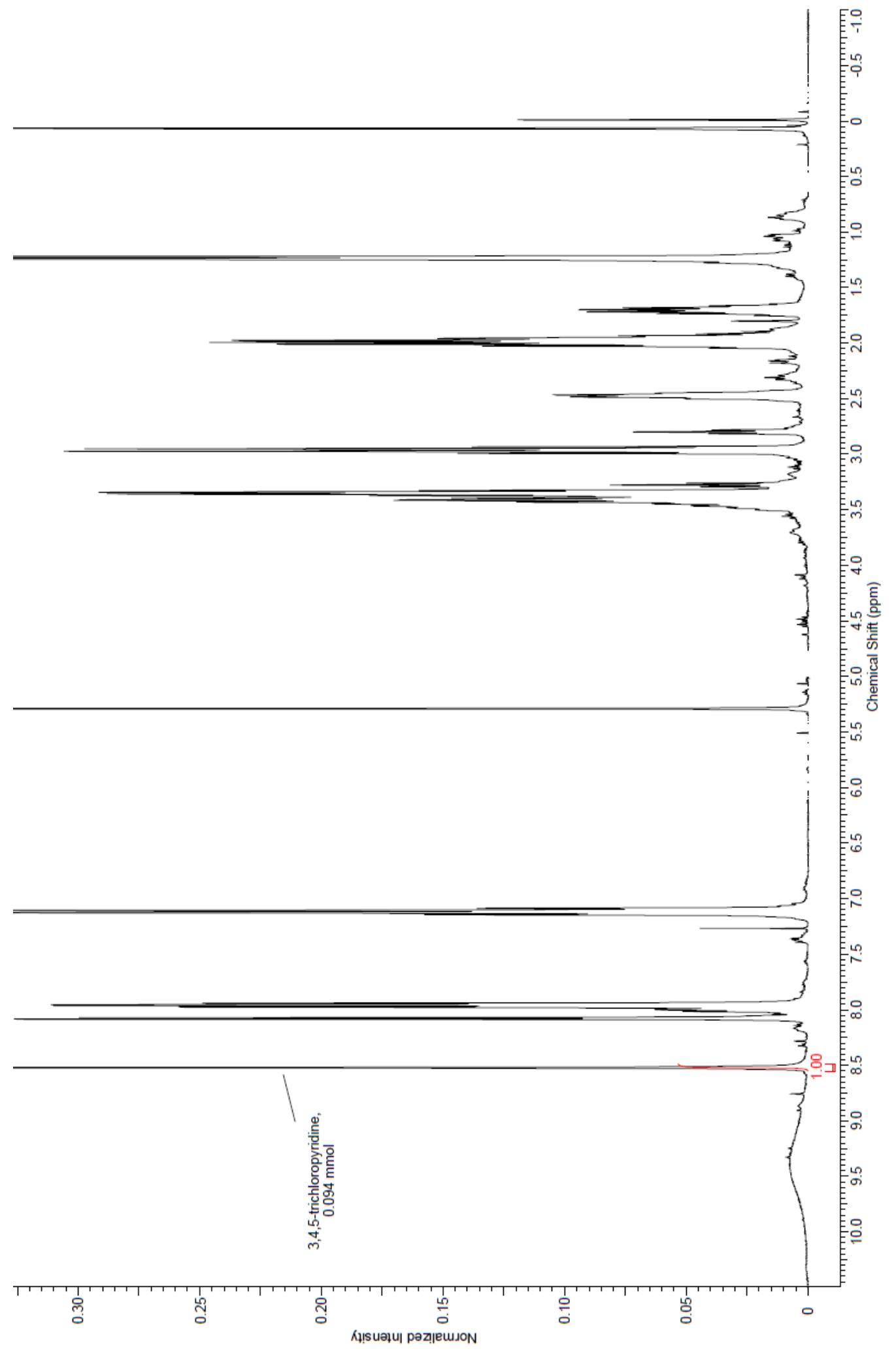


High pH LCMS spectrum of reaction mixture

(Starting material $R_{t}=1.22$ min)

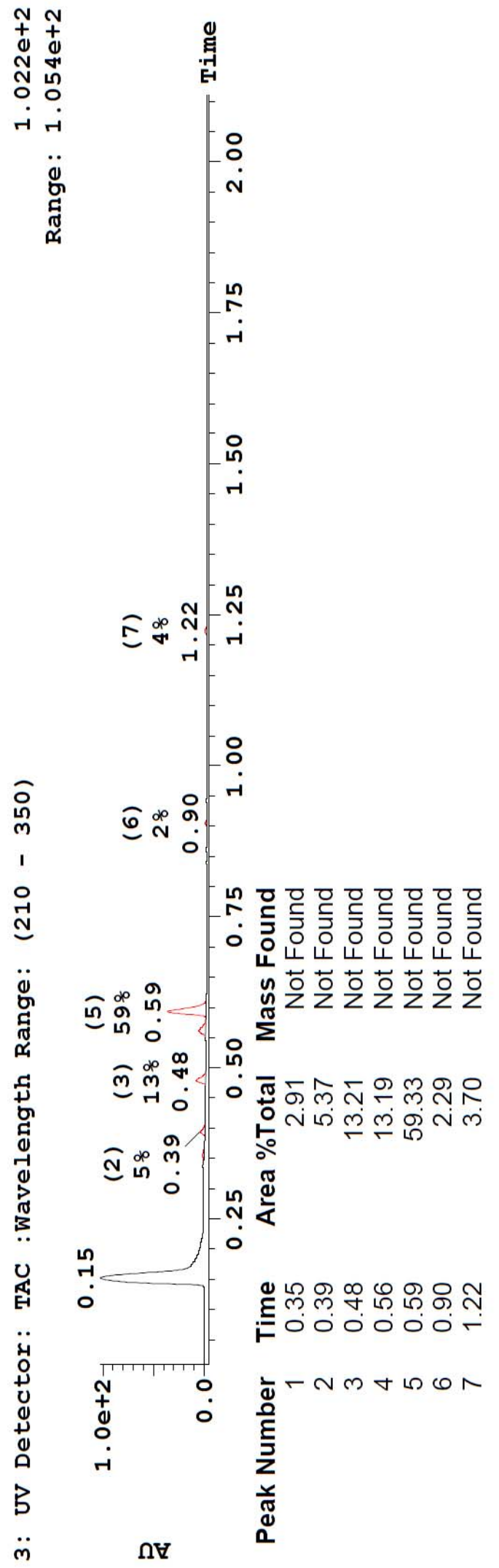


Applied to substrate 4i

${ }^{1}$ H NMR of crude product

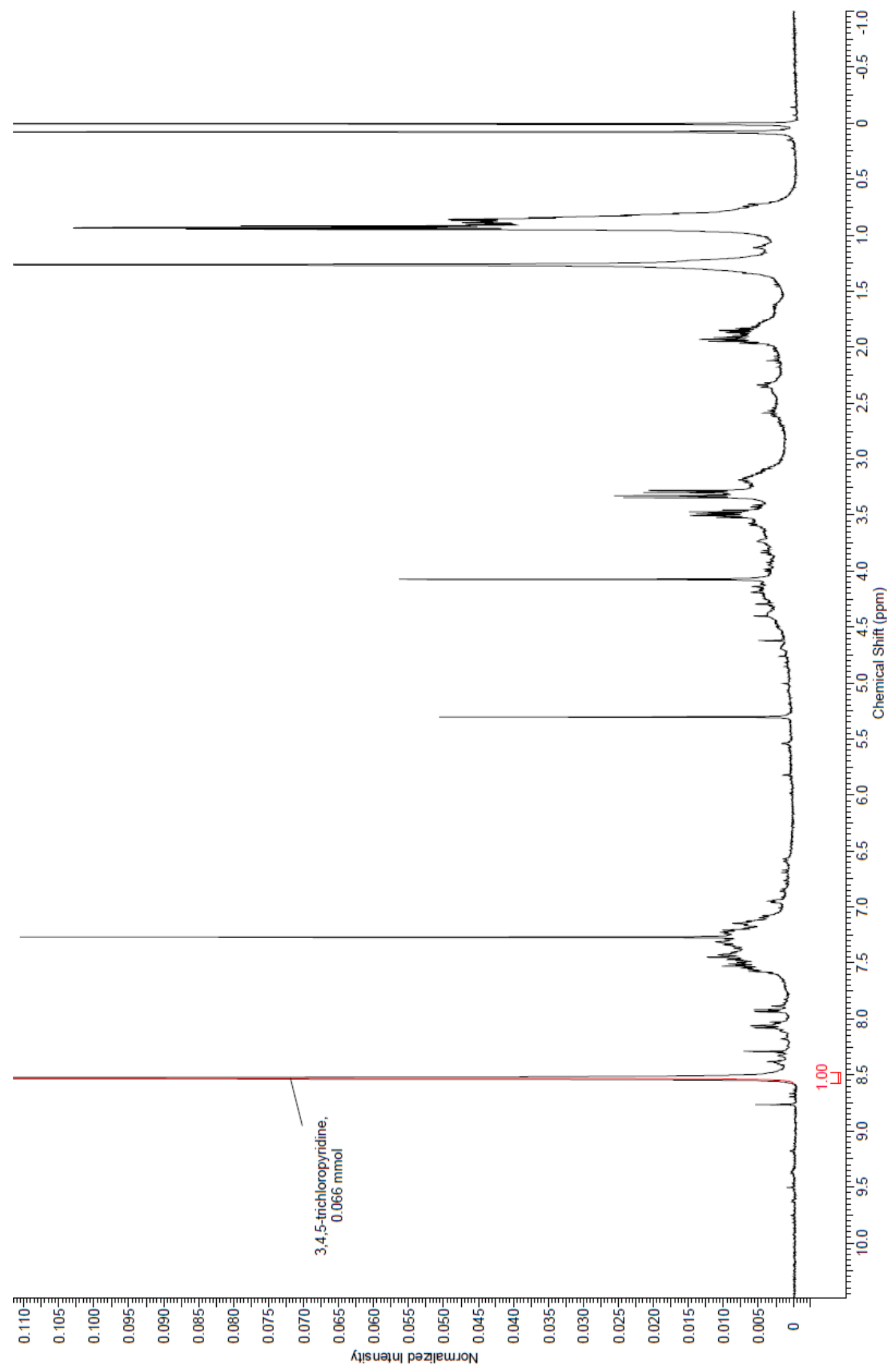


High pH LCMS spectrum of reaction mixture

(Starting material $R_{t}=1.67$ min)

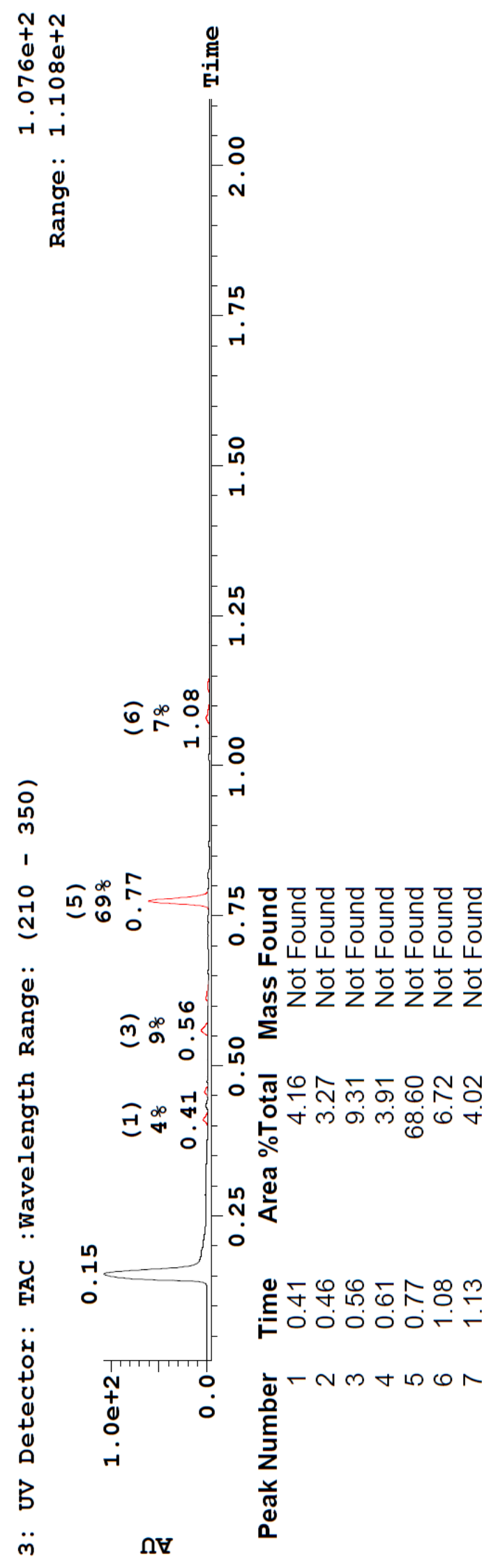


Investigating late-stage oxidation under hypervalent iodine conditions

Applied to substrate $4 \mathrm{~h}$

${ }^{1}$ H NMR of crude product

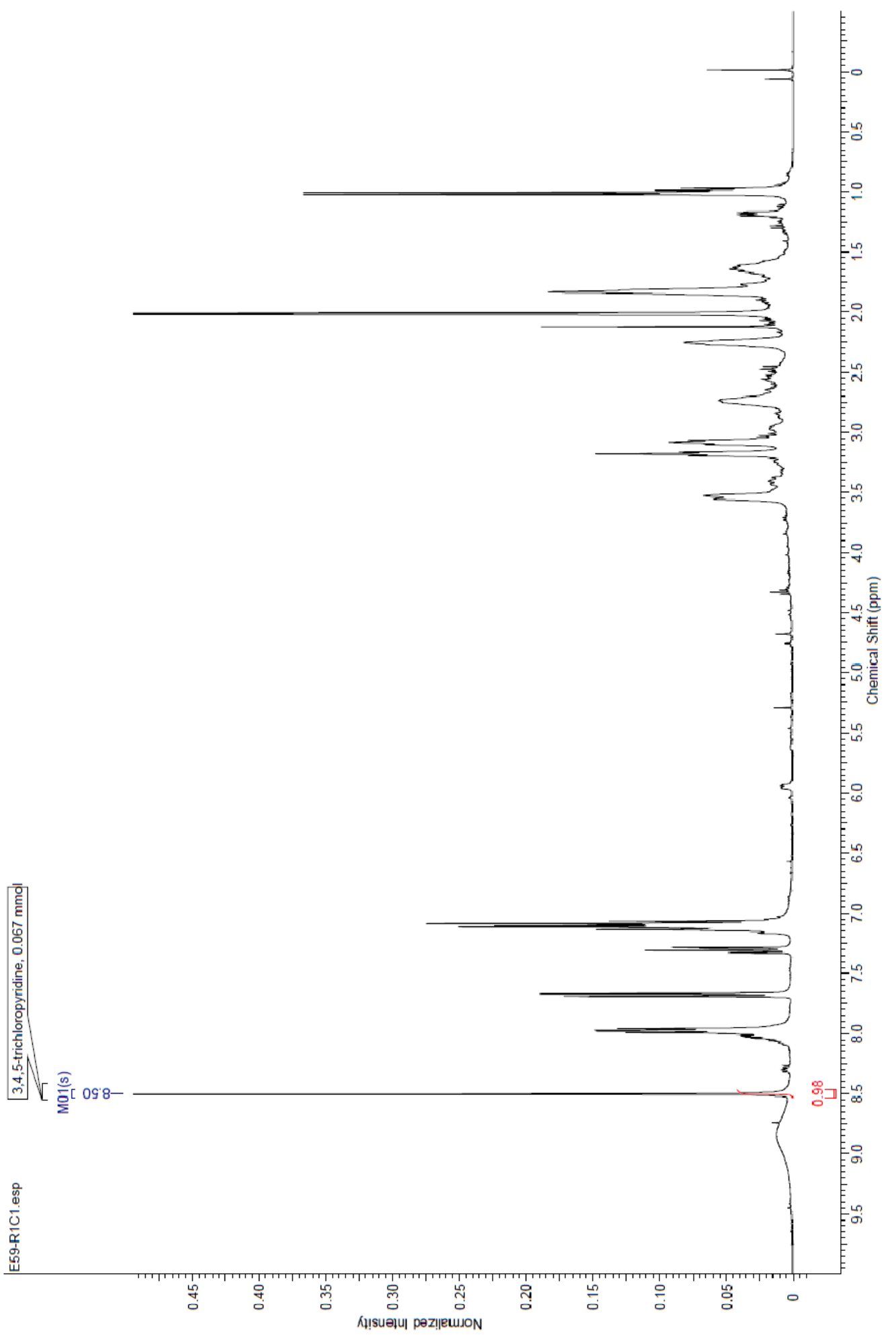


High pH LCMS spectrum of reaction mixture

$\left(\right.$ Starting material $\left.R_{t}=1.21 \mathrm{~min}\right)$

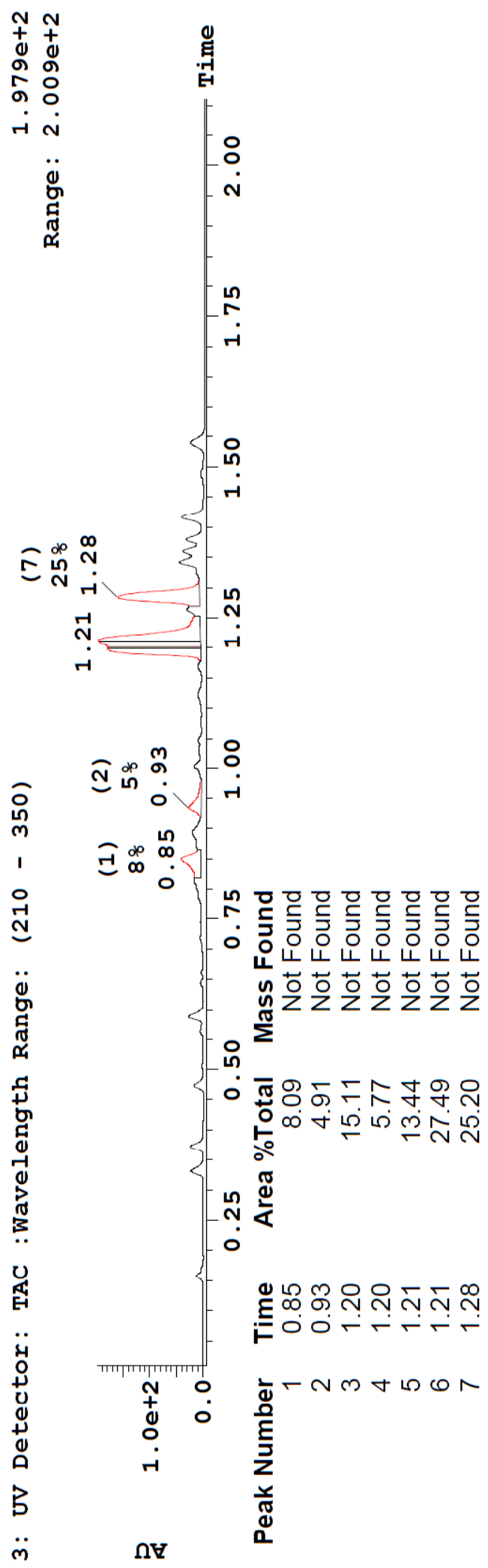


Applied to substrate 4i

${ }^{1}$ H NMR of crude product

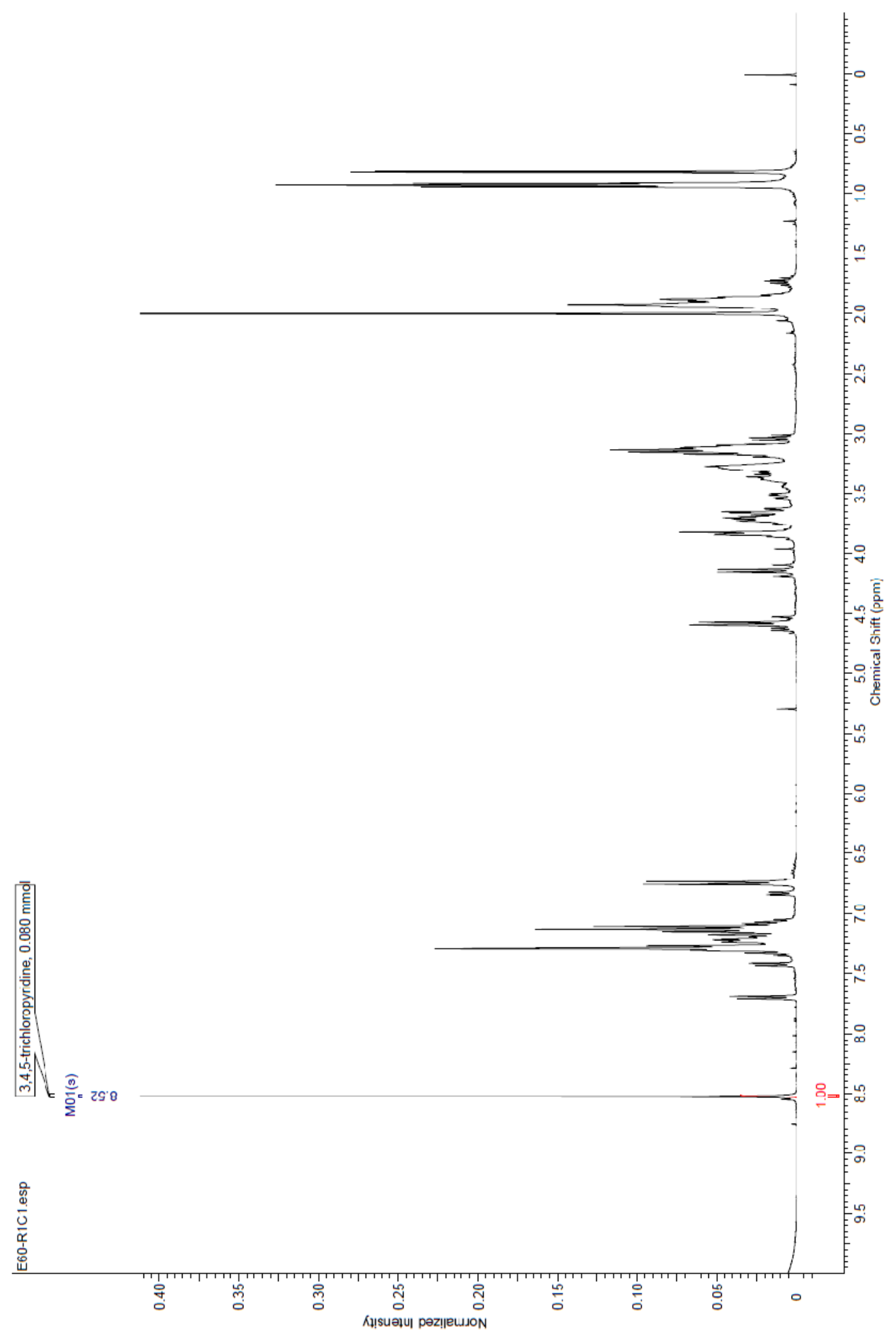


High pH LCMS spectrum of reaction mixture

$\left(\right.$ Starting material $\left.R_{t}=\mathbf{1 . 6 7} \mathbf{~ m i n}\right)$

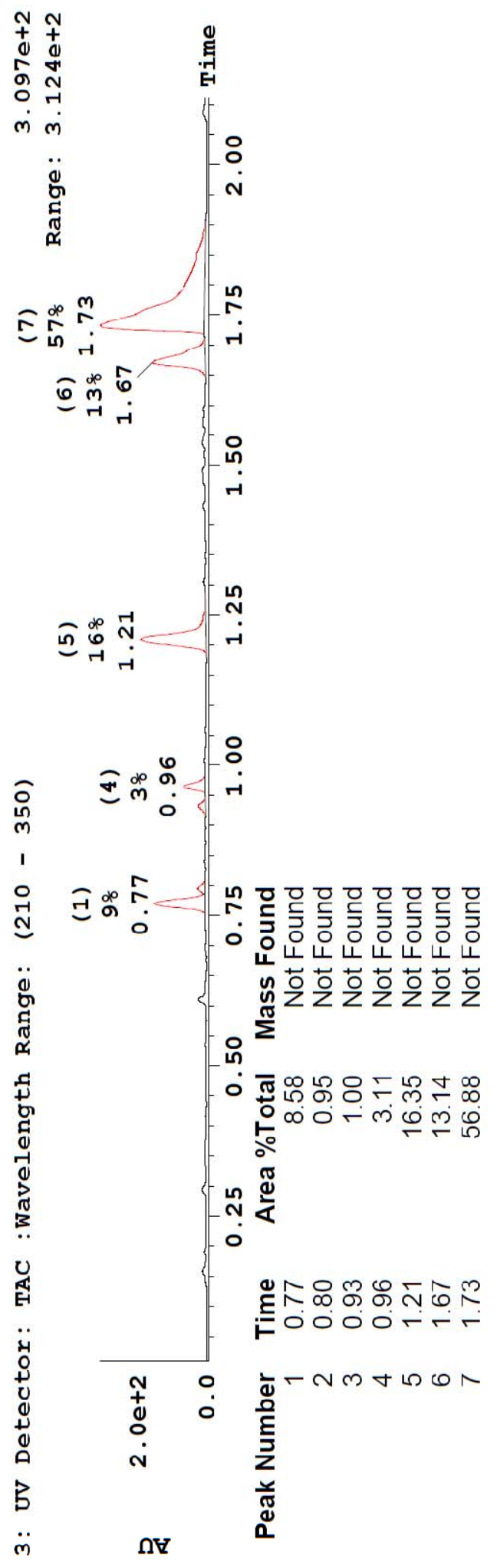




\section{$\underline{\text { References }}$}

[1] H. J. Reich, "Proton Chemical Shifts," can be found under http://www.chem.wisc.edu/areas/reich/nmr/h-data/hdata.htm, 2015.

[2] H. Mayr, A. R. Ofial, E. U. Wurthwein, N. C. Aust, J. Am. Chem. Soc. 1997, 119, $12727-12733$.

[3] P. W. Tan, M. Haughey, D. J. Dixon, Chem. Commun. 2015, 51, 4406-4409.

[4] O. O. Kovalenko, A. Volkov, H. Adolfsson, Org. Lett. 2015, 17, 446-449.

[5] Q. Zou, C. Wang, J. Smith, D. Xue, J. Xiao, Chem. - A Eur. J. 2015, 21, 9656-9661.

[6] Y. Sunada, H. Kawakami, T. Imaoka, Y. Motoyama, H. Nagashima, Angew. Chemie Int. Ed. 2009, 48, 9511-9514.

[7] G. A. Grasa, M. S. Viciu, J. Huang, S. P. Nolan, J. Org. Chem. 2001, 66, 7729-7737.

[8] M. Asami, N. Miyairi, Y. Sasahara, K. Ichikawa, N. Hosoda, S. Ito, Tetrahedron 2015, 71, 6796-6802.

[9] A. M. R. Smith, D. Billen, K. K. Hii, Chem. Commun. 2009, 3925.

[10] J. Deskus, D. Fan, M. B. Smith, Synth. Commun. 1998, 28, 1649-1659.

[11] J. R. Khusnutdinova, Y. Ben-David, D. Milstein, J. Am. Chem. Soc. 2014, 136, $2998-$ 3001 .

[12] C. J. Legacy, A. Wang, B. J. O’Day, M. H. Emmert, Angew. Chemie Int. Ed. 2015, 54, $14907-14910$

[13] G. Breault, C. J. Eyermann, B. Geng, M. Morningstar, F. Reck, Compounds for the Treatment of Multi-Drug Resistant Bacterial Infections, 2006, WO2006134378 (A1).

[14] N. A. Waghmode, A. H. Kalbandhe, P. B. Thorat, N. N. Karade, Tetrahedron Lett. 2016, 57, 680-683.

[15] R. M. Moriarty, R. K. Vaid, M. P. Duncan, M. Ochiai, M. Inenaga, Y. Nagao, Tetrahedron Lett. 1988, 29, 6913-6916. 